\title{
Agricultural use and extent of British Columbia wetlands
}

A.L. VAN RYSWYK and K. BROERSMA

Research Station

Kamloops, British Columbia

J.W. HALL

Research Station

Vancouver, British Columbia

Technical Bulletin 1992-3E

630.4

C 212

R B

$T B$

$1992-3 E$
Research Branch

Agriculture Canada

1992
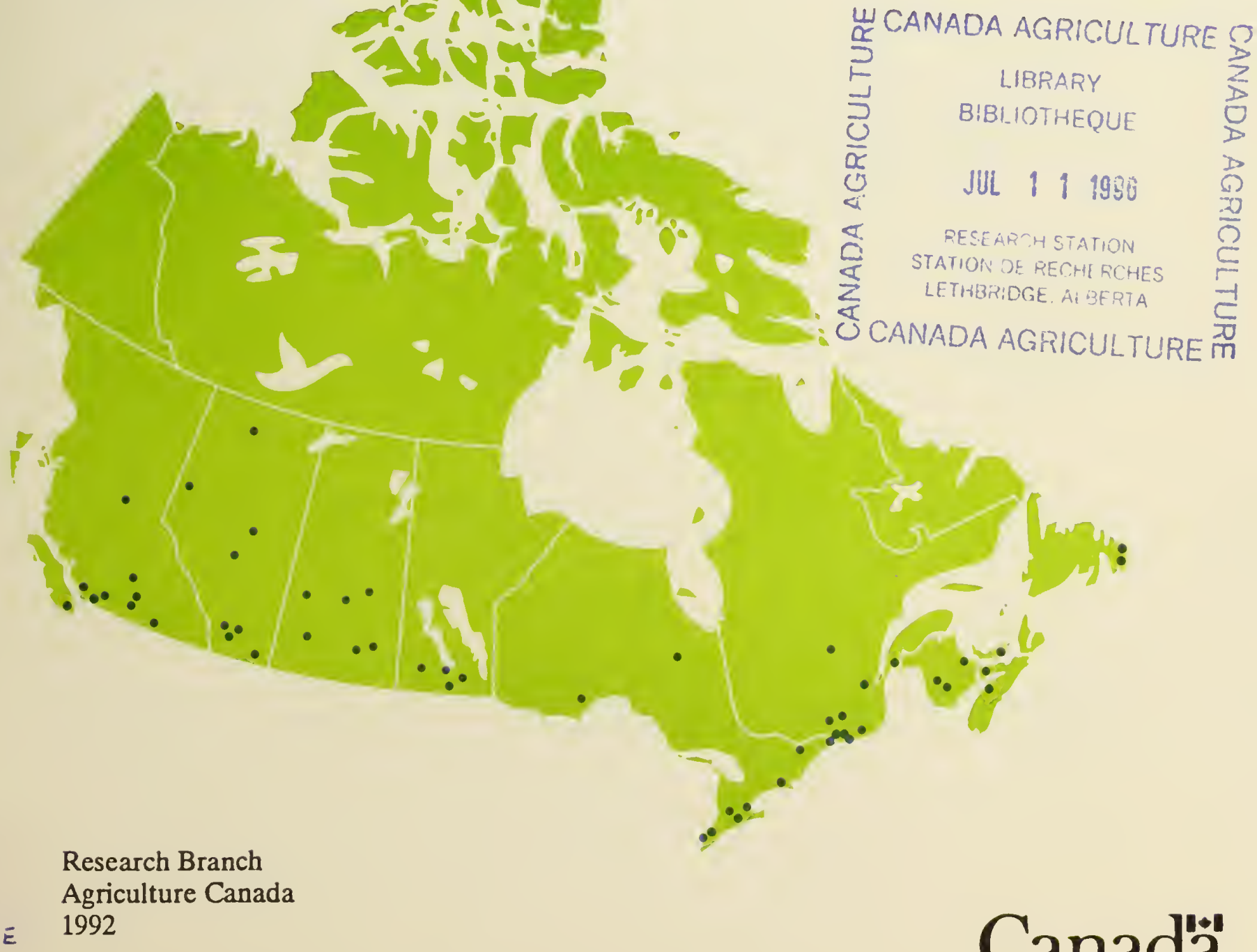

Canadä 
Cover illustration

The dots on the map represent Agriculture Canada research establishments.
Illustration de la couverture Les points sur la carte indiquent les établissements de recherches d'Agriculture Canada. 
23. Page 75 , para 1 , replace last sentence with:

The following is excerpted from Vold et al. (19T7 Vol. 2, pp.134 and 135).

...Gleysolic soils of sufficient area to be delineated, occur on morainal fluvial, and lacustrine materials within the Boreal zone in the Alberta Plateau; and on fluvial deposits within the Subboreal zone in the Rocky Mountain Trench. Very few Gleysolic soils occur in the Rocky Mountains or Rocky Mountain Foothills.

The most extensive area of Gleysolic soils occurs north of Muskeg Lake in the northeast portion of the study area. Two other relatively large areas occur along Hiding Creek and South Redwillow River in the east.

...Fibrisols, with well preserved fiber, dominantly occur in the Rocky Mountain Trench and Rocky Mountains. Mesisols, consisting of partially decomposed organic matter, dominantly occur in the Rocky Mountain Foothills and Alberta Plateau regions. Humisols, composed of well decomposed organic materia!, are absent in the study area.

24. Page 87, para 3, line 3, change: (93 H/W) to (93 H/SW, 11, 12, 13).

25. Page 87, para 13, line 2, change: $92 \mathrm{~J} / 1,3$ to $92 \mathrm{~J} / 2,3$.

26. Page 89. Insert between para's 9 and 10:

Moon, D.E. and Selby, C.J. 1983. Wetland systems of the Cariboo-Chilcotin Region of B.C., pp. 54-74. In S.M. Morgan and F.C. Pollett (eds), Proceedings of a peatland inventory methodology workshop. March 9 and 101982 . Ottawa. Land Resource Research Institute, Agriculture Canada and Newfoundland Forest Research Centre, Environment Canada. 121 pp.

27. Page 93 , para 4 , line 3 , change:

$93 \mathrm{P} / 1-12)$ to $93 \mathrm{P} / 2-7,9-10,12 ; 1: 250000$ biophysical groups map accompanies Vol. 1. One example set of 2 maps [93 P/3, Bullmoose Creek] 1:50 000 biophysical soil and terrain groups accompanies Vol. 2; remainder on request from Maps BC).

28. Page 118. Appendix 9.3, Footnote 4, change to:

Bracketed values (columns 6 to 12) are expressed as percentage of map area ( $\mathrm{km}^{2}$ ) taken as $100 \%$ (column 13 ), rounded to nearest $1 \%$, i.e. $0.500 \mathrm{~km}^{2}$ or greater. 
Catherine Berris Associates Inc. Vancouver, B.C. 1993. Burns Bog Analysis. Prepared for British Columbia Ministry of Environment Lands and Parks. June 1993. 58 pp.

14. Page 47. Insert after para 3:

Purple loosestrife is native to Eurasia (White and Haber 1992). It was introduced to the New England seaboard by early 1800 's accidentally or intentionally (medicinal herb, home garden, wildflower mixes) and spread to the Fraser Lowland by 1940 where it is still limited but has great potentlal to spread in wetlands. It spreads by prolific seed production and competes strongly with native and cultivar plant species to the point that waterfowl and furbearers may be displaced because of diminished food or cover values. Most promising control is biological by several insects but several years of field trials are required to determine their efficacy.

White, D.J. and Haber, E. 1992. Invasive plants of natural habitats in Canada. Part 1: Wetland species. Prepared for Canada Wildlife Service by D.J. White and E. Haber, Canadian Museum of Nature, Environment Canada, Ottawa. 51 pp.

15. Page 47-52 inclusive. Short heading. Change: 6.2 to 6.3 .

16. Page 57, para 3, change:

line 2. Discontinuous permafrost occurs in peat plateaux to Continuous permafrost occurs in peat plateau.

line 7. Swamps are common. to Swamps are locally common.

para 7 . about $56 \%$ to $55 \%$.

17. Page 60, para 1, line 5. (See also Page 74, para 6, line 2). Change:

$93 \mathrm{P} / 1-12)$ to $93 \mathrm{P} / 2-7,9-10,12)$.

18. Page 60, para 2, line 4. Add after ...yields.:

The Organic soils are very strongly acid in the upper layers, have very poor drainage, and offer great difficulty for clearing of forest and for cultivation. (Hortie et al. 1970, ...

19. Page 60, para 2, lines 4 and 5. (See also Page 75, para 2, line 3 and Page 84, para 10. line 4). Replace map sheet designations with:

(portions $83 \mathrm{D} / 11,13,14 ; 83 \mathrm{E} / 3,4 ; 93 \mathrm{H} / 1,7-11,15$, but excluding portions $93 \mathrm{H} / 13$, $14 ; 93 \mathrm{G} / 16 ; 93 \mathrm{~J} / 1,8$ in Interior Plateau, north, central portion. 1:126 720).

20. Page 64, para 4, line 6, change: northeast to northwest.

21. Page 68, para 5, line 4, change: (93 H/W) to $(93 \mathrm{H} / 4,5,12,13$; but excluding $3,6,11$ in Mountain).

22. Page 69, para 1, line 5, change: (Lord and Green 1984) and Barkerville (Lord 1985) to (Lord 1984) and Barkerville (Lord and Green 1985). 
9. Page 39, para 2, change:

line $4.83 \%$ to $82 \%$.

line 7. of the area. to of the wetland area.

line 9. South Coastal to South Coast Pacific Oceanic.

10. Page 41. Insert after para 4:

Ward (1989) reported $419 \mathrm{~km}^{2}(13.6 \%)$ of wetlands in a study area $\left(3092 \mathrm{~km}^{2}\right)$ adjacent to the Pitt and Fraser Rivers and Boundary and Mud Bays. These wetlands were composed of the following wetland classes (NWWG 1987): shallow water $64.4 \%$, marsh $14.6 \%$, fen $5.7 \%$, bog $4.5 \%$, and swamp $3.4 \%$, as well as gravel bar $7.5 \%$. Ward (19:39) further discussed the degree of disturbance of these wetland, summarized as undisturbed $72 \%$, moderately disturbed $22 \%$, and disturbed $6 \%$. This study amalgamates previous studies, "to provide the means for accommodating a growing population and economy, while maintaining the quality and productivity of the Fraser Estuary's natural environment".

Ward, P. 1989. Wetlands of the Fraser Lowland, 1989: Summary Report. Technical Report Series No. 156. Canada Wildlife Service, Pacific and Yukon Region, P.O. Box 340, Delta, B.C. Canada. V4K 3Y3. 36 pp.

11. Page 42. Insert after para 6:

An extensive information catalogue has been prepared (Hagen 1984) including references to imagery, base mapping, surveys, reports, assessments, and related intormation for selected $B C$ coastal estuaries and embayments.

Hagen, M.E. 1984. British Columbia estuarine information catalogue. Volume II Lower Mainland - Sunshine Coast. Prepared for Land Directorate, Environment Canada, April, 1984, Vancouver, B.C. 215 pp.

12. Page 46, para 2, change line 8 to:

...require acid soils. However, the latter do not necessarily require Organic soils (personal communication Dr. G. Eaton, UBC). The bog is adjoined on two sides by currently....

13. Page 46. Insert after para 2:

Burns Bog represents one of the largest tracts ( $4000 \mathrm{ha}$ ) of domed bog wetland primarily occupied by sphagnum vegetatlon, in the Fraser Lowland and Delta Municipality. Seven studies within Delta municipality are currently being undertaken with provincial funding that reflect the growing provincial concern of future land use for the increasing urban and industrial demand for land in the southwest sector of BC. One of these studies (Catherine Berris 1993) for consideration of Burns Bog within the provincial Protected Area Strategy included computer Geographic Information Systems (GIS) maps for primary natural resources and human activities followed by detailed discussion of potential primary land uses of protected area (5 concepts ranging from total to no protection), recreation, agriculture, peat extraction, waste management, and others (golf course, race track, water supply for agriculture). 


\section{AGRICULTURAL USE AND EXTENT OF BRITISH COLUMBIA WETLANDS}

\section{To The Reader}

The authors would appreciate receiving your comments for improvement and notations of other significant errors or ommissions in this bulletin which we can consider, along with the errata noted below, at such time that a second printing or revision occurs. Thank you for your attention.

Kamloops Research Station

Research Branch, Agriculture Canada 3015 Ord Rd, Kamloops, B.C. Canada

V2B 8 A9

1. Page following the title page. Under "Produced by the", after Research Program Service add:

Figures 2 through 7 were designed, produced and printed by Information Systems and Cartography, Land Resource and Research Centre (now Centre for Land and Biological Resources Research) Central Experimental Farm, Ottawa.

2. Page 2 of the Contents. Appendix 9.3, change title to:

Area of Wetlands by $0100 \mathrm{~N} \times 0200 \mathrm{~W}\left(1^{\circ} 00^{\prime}\right.$ North latitude by $2^{\circ} 00^{\prime}$ West Longitude) Map Area.

3. Page ii. Under Acknowledgements, begin paragraph 1 with:

Recognition is extended to Dr. V.C. (Bert) Brink, Professor Emeritus, Department of Plant Science, University of British Columbia, who flrst encouraged studies of the coastal foreshores and of the interior wetlands of B.C.

4. Page 11, Figure 1: Change note in lower left: $1300 \mathrm{E}$ to $13000 \mathrm{~W}$.

5. Page 13, para 6, line 8, add:

CLI and/or provisional soil maps were used for $93 \mathrm{G} / 16,93 \mathrm{H} / 14$ and $93 \mathrm{~J} / 1,8$ instead of published soil maps (see Figure 1) by Hortie et al. (1970).

5. Page 13, para 8, line 4. Replace last sentence with:

Only organic areas were estlmated by dot planimeter for 93 1/9-16 (Vold et al. 1977, Vol. 1) on biophysical groups maps (1:250 000) because 1:50 000 biophysical soil maps were not obtained.

6. Page 29. Figure 8, change: After Holland (1976) see Table 3 to After Holland (1976) see Table 1.

7. Page 37, para 3 and 4, line 1, change: (Table 2) to (Table 3).

8. Page 38, para 1, line 2, change: (Chapter 6) to (Chapter 8). 


\title{
Agricultural Use and Extent of British Columbia Wetlands
}

\author{
A.L. van Ryswyk and K. Broersma \\ Research Station \\ Kamloops, British Columbia \\ J.W. Hall \\ Research Station \\ Vancouver, British Columbia
}

Technical Bulletin 1992-3E

Research Branch

Agriculture Canada

1992 
Copies of this publication are available from:

Dr. K. Broersma, Superintendent

Kamloops Research Station

Research Branch, Agriculture Canada

3015 Ord Rd.

Kamloops, B.C. V2B 8 A9

CMinister of Supply and Services Canada 1992

Cat. No. A54-8/1992-3E

ISBN 0-662-19503-5

Produced by the:

Kamloops Research Station

and

Research Program Service

Printed by:

Wayside Press, Vernon 


\section{CONTENTS}

List of Tables

List of Figures

List of Abbreviations

Acknowledgements

Summary

Résumé

1. INTRODUCTION 1

1.1 Definition 1

$1.2 \quad$ Purpose and Background 1

$1.3 \quad$ Wetland Formation

2. CANADIAN WETLAND CLASSIFICATION SYSTEMS 3

2.1 Wetland Classification Systems 3

$2.2 \quad$ Canadian Soil Classification 3

$2.3 \quad$ Canadian Wetland Classification 4

2.4 National Topographic Map Series Classification 5

3. OTHER CLASSIFICATION SYSTEMS 6

4. METHODS 9

4.1 Map Sources 9

$4.2 \quad$ Data Treatment 10

4.3 Reliability and Errors 13

5. AGRICULTURAL USE OF WETLANDS 33

6. AGRICULTURAL USE AND EXTENT OF WETLANDS BY PHYSIOGRAPHIC SUBDIVISION GROUPS 37

6.0 Introduction 37

6.1 Hecate Depression 39

6.2 Georgia Depression 41

6.3 Interior Plateau, North 47

$6.4 \quad$ Interior Plateau, South 53

$6.5 \quad$ Northwestern Plateaux and Basin 55

6.6 Liard Plain 57

6.7 Mountain 57

6.8 Fort Nelson Lowland 61

6.9 Peace River Lowland 62 
7. SUPPLEMENTARY WETLAND SOIL INFORMATION 64

$\begin{array}{lll}7.0 & \text { Introduction } & 64\end{array}$

$\begin{array}{lll}7.1 & \text { Hecate Depression } & 64\end{array}$

$\begin{array}{lll}7.2 & \text { Georgia Depression } & 64\end{array}$

$\begin{array}{lll}7.3 & \text { Interior Plateau, North } & 68\end{array}$

$\begin{array}{lll}7.4 & \text { Interior Plateau, South } & 70\end{array}$

$\begin{array}{ll}7.5 & \text { Northwestern Plateaux and Basin }\end{array}$

$\begin{array}{ll}7.6 & \text { Liard Plain } \\ 7.72\end{array}$

$\begin{array}{lll}7.7 & \text { Mountain } & 73\end{array}$

$\begin{array}{lll}7.8 & \text { Fort Nelson Lowland } & 77\end{array}$

$\begin{array}{lll}7.9 & \text { Peace River Lowland } & 79\end{array}$

8. LITERATURE CITED 80

9. APPENDICES

Appendix 9.1 Canadian Systems of Soil Classification for Cryosolic, Gleysolic and Organic Soil Orders (ACECSS 1987).

Appendix 9.2 Descrip. of Wetland Classes, Table of Wetland Forms(NWWG 1987).

105

Appendix 9.3 Area of Wetlands by $0100 \mathrm{~N}$ lat. $\times 0200 \mathrm{~W}$ long. Map Area.

Appendix 9.4 Climate of BC (Schaefer 1971).

119

Appendix 9.5 BC Agriculture Land Reserves and Livestock Distribution in Cattle Grazing Areas (Farley 1979). 


\section{LIST OF TABLES}

Table 1. British Columbia wetland areal distribution by physiographic subdivision groups.

Table 2. Climatic capability for agriculture (CCA) classes for British Columbia.

Table 3. Elevational distribution of British Columbia wetland area in $\mathrm{km}^{2}$ and \% of total $\mathrm{km}^{2}$.

Table 4. Elevation, climatic parameters and climatic capability for agriculture of selected stations for Hecate, Depression and Mountain (Insular) and for Georgia Depression groups.

Table 5. Elevational distribution of wetland area in $\mathrm{km}^{2}$ and $\%$ of total map area for the Georgia Depression group.

Table 6. Elevational distribution of wetland area in $\mathrm{km}^{2}$ and $\%$ of total map area for the Interior Plateau, north group.

Table 7. Elevation, climatic parameters and climatic capability for agriculture of selected stations for Interior Plateau, north and south groups.

Table 8. Elevational distribution of wetland area in $\mathrm{km}^{2}$ and $\%$ of total map area for the Interior Plateau, south group.

Table 9. Elevation, climatic parameters and climatic capability for agriculture for selected stations for northern and Mountain groups.

Table 10. Elevational distribution of wetland area in $\mathrm{km}^{2}$ and $\%$ of total map area for the southeastern (Kootenay) portion of the Mountain group.

Table 11. Elevational distribution of wetland area in $\mathrm{km}^{2}$ and $\%$ of total map area for the Fort Nelson Lowland group.

Table 12. Elevational distribution of wetland area in $\mathrm{km}^{2}$ and $\%$ of total map area for the Peace River Lowland group.

Table 13. Summary of wetland area $\left(\mathrm{km}^{2} ; \%\right.$ of total map area, i.e. $4020 \mathrm{~km}^{2}=$ $100 \%)$ occupied by classified soils in the Langley-Vancouver map area.

Table 14. Summary of wetland area $\left(\mathrm{km}^{2} ; \%\right.$ of total map area, i.e. $4020 \mathrm{~km}^{2}=$ $100 \%)$ occupied by surficial deposits (materials) in the LangleyVancouver map area.

\section{LIST OF FIGURES}

Figure 1. Map sources plotted on national topographic map grid.

Figure 2. Total wetland (Gleysolic and Organic).

Figure 3. $\%$ total Gleysolic soil wetland.

Figure 6. $\%$ wetland (Gleysolic and Organic); 600 to $1200 \mathrm{~m}$ elevation range.

Figure 9. E-W transects across British Columbia indicating wetland distribution, extent and average estimated elevation. 


\section{LIST OF ABBREVIATIONS}

$\begin{array}{ll}\text { ACECSS } & \text { Agriculture Canada Expert Committee on Soil Survey } \\ \text { ALR } & \text { Agriculture Land Reserve } \\ \text { BC } & \text { British Columbia } \\ \text { BCHPA } & \text { British Columbia Hydro and Power Authority } \\ \text { BCMAFF } & \text { British Columbia Ministry of Agriculture (and Food, Fisheries, or Fisheries and } \\ & \text { Food), British Columbia Department of Agriculture } \\ \text { BCME } & \text { British Columbia Ministry of the Environment } \\ \text { BCMF } & \text { British Columbia Ministry of Forests } \\ \text { BGCZ } & \text { biogeoclimatic zone(s) } \\ { }^{\circ} \text { C } & \text { degrees Celsius } \\ \text { CCA } & \text { climatic capability for agriculture } \\ \text { CLI } & \text { Canada Land Inventory } \\ \text { CMB } & \text { climatic moisture balance } \\ \text { CMS/D } & \text { climatic moisture surplus/deficit } \\ \text { EGDD } & \text { effective growing degree day }\left({ }^{\circ} \mathrm{C} \text { day) }\right. \\ \text { FFP } & \text { freeze free period (day) } \\ \text { GDD } & \text { growing degree day ( }{ }^{\circ} \mathrm{C} \text { day) } \\ \text { LRRC } & \text { Land Resource Research Centre } \\ \text { NTS } & \text { National Topographic Series (Canada map designation system) } \\ \text { NWWG } & \text { National Wetlands Working Group } \\ \text { PET } & \text { potential evapotranspiration } \\ \text { WR } & \text { wetland region(s) or subdivision of region }\end{array}$

\section{ACKNOWLEDGEMENTS}

Grateful appreciation is extended to John Zacharias (retired, Head, Field Crops Branch, British Columbia Ministry of Agriculture) who initially suggested the study and provided funding to begin data compilation; Mary Redmond and Karen Gorse, Maps BC, for providing copies of interim Canada Land Inventory (CLI) maps; and Herbert Luttmerding, British Columbia Ministry of Environment for providing further interim $\mathrm{CLI}$ and interim soil maps.

Special acknowledgement is given to several dedicated workers who undertook many onerous tasks over several months. Data compilation was performed by Maureen Christofferson, Alice Cogley, Janet Doner, Peter Falsetta, Linda James, Bruce Roddan and Michelle White. Drafting and printing of Figures 2 to 7, inclusive, were authorized by Dr. Keith Valentine, former Head, Information Systems and Cartographic Unit, Land Resource Research Centre, Agriculture Canada, Ottawa and completed by Roy Hoekstra (retired) under direction of Brian Edwards. Bruce Roddan, soils technician, Kamloops Research Station, prepared the remaining figures. We would especially like to thank Carol Fagan for doing much of the word processing by putting together the various drafts of this bulletin.

The efforts of the following reviewers are especially appreciated: Ken Awmack, Peter Fofonoff, Alex Green, Terry Lord, Lawrence Lowe, Herbert Luttmerding, Del Meidinger, Jim Pojar, Al Robertson, Charles Tarnocai. However, any errors or misinterpretations remain the responsibility of the authors. 
- iii -

\section{Agricultural use and extent of British Columbia wetlands}

\section{SUMMARY}

Wetland has the water table at, near, or above the land surface, or is saturated for long enough periods to promote wetland or aquatic processes. Wetlands are recognized for renewable resource values that include habitat for a wide variety of wildlife, recreation opportunities in unique ecological systems, regulation of water regimes, production of trees, horticulture or forage crops in suitable climates.

This study summarizes British Columbia's (BC) wetland area, in map and tabular form by area and elevation categories, and discusses literature relating to its agricultural uses. The areal extent is presented for nine physiographic subdivision groups with a further partitioning into $300 \mathrm{~m}$ elevation categories. Organic and Gleysolic soil wetlands were separated using soil or Canada Land Inventory (CLI) map sources for $40 \%$ of the BC land area. National Topographic Series maps provided an undifferentiated wetland category for the remainder.

Total wetland covers $52883 \mathrm{~km}^{2}$ or $5.6 \%$ of the total BC land area, $948600 \mathrm{~km}^{2}$. The soil/CLI surveyed area accounted for $27110 \mathrm{~km}^{2}(46 \%)$ of $\mathrm{BC}$ wetland, $10068 \mathrm{~km}^{2}(42 \%)$ of which is Gleysolic soil.

The Cordilleran Physiographic Region occupies $89 \%$ of the total BC land area, and contains $2 \%$ wetland, representing $29 \%$ of total $B C$ wetland. The remainder $(11 \%)$ is occupied by the Interior Plains Region in northeastern BC and contains 36\% wetland, representing $71 \%$ of BC's wetland. Total BC wetland is distributed, in descending order, among nine physiographic subdivision groups: Fort Nelson Lowland 52\%, Peace River Lowland 18\%, north Interior Plateau $12 \%$, Mountain $8 \%$, Hecate Depression 4\%, south Interior Plateau 2\%, Northwestern $2 \%$, Georgia Depression 1\%, and Liard Plain 1\%.

Six percent of the total wetland area occurs below 300 m elevation, almost all in the coastal Depressions. The largest area, $46 \%$, occurs in the 300 to $600 \mathrm{~m}$ category, $96 \%$ of that in the Fort Nelson Lowlands of northeastern BC. The 600 to $900 \mathrm{~m}$ category includes the second largest area of wetland (34\%), $49 \%$ of that in the Peace River Lowland of northeastern BC. Above $900 \mathrm{~m}$, wetland area decreases consistently with each $300 \mathrm{~m}$ increase in elevation to the $>1500 \mathrm{~m}$ category, inclusive. The 300 to $1200 \mathrm{~m}$ elevation range includes $89 \%$ of the total area of $\mathrm{BC}$ wetlands.

The amount of wetland, however is less important than the quality of soil characteristics and climate for production of agricultural crops. Wetland soils with well decomposed organic surface layers are generally the most fertile. Agriculture potential of wetlands in each of the physiographic region is discussed in relation to their areal and elevational extent, Canadian Wetland Region Class, climatic capability for agriculture, and soil characteristics.

Climate of the Hecate Depression along the west coast of $\mathrm{BC}$ is not generally suited for agricultural crops due to excessive precipitation leading to drainage difficulties, cool temperatures and low solar radiation. However, climate of the Georgia Depression in the extreme southwest of $\mathrm{BC}$ is among the best in the province, capable of supporting a wide range of horticultural and forage crops. About $10 \%$ of the Georgia Depression wetlands have well decomposed surface 
layers with high fertility. Proper water control structures can effectively control drainage and in many instances provide subirrigation during periodic summer droughts.

Wetlands of the north Interior Plateau produce about one-half of the forage required for the beef cattle herds of that area. The dominant wetlands have moderately well decomposed Organic soils, requiring fertilizer to produce high forage yields. They are especially useful in this area of recurrent summer drought when perennial water tolerant forage species are grown under properly managed water control systems. This type of management results in little deterioration of the Organic soil resource.

Wetland area of the south Interior Plateau and the southern Mountains is limited. Those at lower elevations in the major valleys are useful for horticultural and forage crops during the drought-prone summers when water control is properly managed. At higher elevations under harsher climates, only natural forage species are grown for domestic livestock.

The climate of the northern Mountains, Northwestern, Liard Plain and Fort Nelson and Peace River Lowlands generally support only forage crops on wetland soils because cool air temperatures do not warm the saturated wetland soils quickly enough and lead to frost hazards in low lying areas. Guide outfitters use forage from these areas mainly for horses. 


\section{Les terres humides de la Columbie-Britannique : leur superficie et leur utilisation en agriculture}

\section{RÉSUMÉ}

Dans les terres humides, la nappe phréatique se situe soit à la surface même du sol, soit juste en dessous ou au-dessus. On retrouve aussi dans cette catégorie les terres saturées d'eau pendant des périodes assez longues pour créer les conditions propres aux zones humides ou aux processus aquatiques. Les terres humides sont une source reconnue de ressources renouvelables et servent, entre autres, d'habitat à une vaste gamme d'espèces sauvages animales ou végétales et d'écosystème unique à des activités récréatives; elles sont aussie propices à la régulation des régimes hydrologiques, à la production de bois d'ouvre aisni qu'à la production horticole et fourragère lorsque le climat s'y prête.

La présente étude contient des cartes et des tableux dans lesquels les terres humides de la Columbie-Britannique (C.-B.) sont classées d'après la superficie et l'altitude; on y traite également des publications qui portent sur l'utilisation de ces zones en agriculture. Les terres son réparties en neuf subdivisions physiographiques, qui sont elles-mêmes divisées en catégories d'altitude de $300 \mathrm{~m}$ chacune. On s'est servi de cartes des sols ou de l'Inventaire des terres du Canada (ITC) pour distinguer les zones humides à sols organiques ou gleysoliques pour une proportion de $40 \%$ des terres de la C.-B. Pour le reste des terres, on a utilisé le Système de référence cartographique national qui comporte un catégorie unique pour l'ensemble des zones humides.

La superficie totale des zones humides est de $52883 \mathrm{~km}^{2}$, soit 5,6\% de la surface totale des terres de la C.-B. $\left(948000 \mathrm{~km}^{2}\right)$. La région répertoriée par les cartes des sols ou l'ITC correspond à $27110 \mathrm{~km}^{2}$, soit 46\% des zones humides de la C.-B., dont $10068 \mathrm{~km}^{2}$ (42\%) sont des sols gleysoliques.

La région physiographique de la Cordillère occupe $89 \%$ de la superficie totale des terres de la C.-B.; $2 \%$ des terres de cette région sont humides, ce qui équivaut á $29 \%$ de la totalité des zones humides de la C.-B. Le reste des terres humides (11\%) est situé dans la région des plaines Intérieures du nord-est de la provicne, dont $36 \%$ de la superficie est couverte par des zones humides, qui représentent $70 \%$ de l'ensemble des terres humides de la C.-B. Par ordre décroissant, la répartition des zones humides de la C.-B. entre les neufs subdivisions physiographiques est la suivant: basses-terres de Fort Nelson $52 \%$, basses-terres de la rivière de la Paix $18 \%$, plateau Intérieur du Nord $12 \%$, montagnes $8 \%$, bassin d'Hécate $4 \%$, plateau Intérieur du Sud 2\%, Nord-Ouest 2\%, bassin de la George 1\% et plaine de la Liard 1\%.

La presque totalité des $6 \%$ de zones humides qui se trouvent à moins de $300 \mathrm{~m}$ d'altitude occupe des bassins côtiers. La plus grande superficie de zones humides, à savoir $46 \%$, se situe entre 300 et $600 \mathrm{~m}$ d'altitude; $96 \%$ d'entre elles se rencontrent dans la région des basses-terres de Fort Nelson au nord-est de la C.-B. C'est entre 600 et $900 \mathrm{~m}$ que l'on trouve la deuxième superficie en importance (34\%), dont $49 \%$ sont dans la région des basses-terres de la rivière de la Paix au nord-est de la province. Au-dessus de $900 \mathrm{~m}$, la superficie des zones humides diminue graduellement à chaque tranche de $300 \mathrm{~m}$ d'altitude, y compris la zone de $1500 \mathrm{~m}$ et plus. Quartre-vingt-neuf pour cent des zones humides de la C.-B. se situent entre 300 et $1200 \mathrm{~m}$ d'altitude. 
Pour ce qui est de l'agriculture, la superficie des zones humides revêt une importance beaucoup moindre que la qualité des sols et le climat. Les sols humides dont les couches superficielles sont composées de matière organique décomposée sont généralement les plus fertiles. Le potentiel agricole de chaque groupe physiographique est évalué en fonction de la superficie et de l'altitude, du système de classification des terres humides du Canada, du climat et des caractéristiques des sols.

Le climat du bassin d'Héctate, situé le long de la côte ouest de la C.-B., est en général peu propice à l'agriculture en raison des précipitations très abondantes qui nuisent au drainage, des températures fraîches et de la faiblesse des radiations solaires. En outre, le climat du bassin de Géorgie, à l'extrême sụd-ouest de la C.-B., est l'un de ceux, dans la province, qui se prêtent le mieux à un large éventail de production horticoles et fourragères. Environ $10 \%$ des zones humides du bassin de Géorgie possèdent des couches superficielles bien décomposées et très fertiles. En ayant recours à des aménagements hydrologiques, on peut faciliter le drainage et, dans bien des cas, procurer une irrigation souterraine pendant les séchesresses périodiques de l'été.

Les zones humides du plateau Intérieur de Nord produisent environ la moitié du fourrage consommé par les troupeaux de bovins de boucherie du centre Intérieur de la C.-B. Les principales zones humides possèdent des sols organiques plus ou moins bien décomposés qui doivent être fertilisés pour produire un rendement élevé en fourrage. Dans cette zone frappée de sécheresses estivales périodiques, l'utilité des zones humides pour la culture des espèces fourragères vivaces depend de la régularité des régimes hydrologiques, car, grâce à une bonne gestion, on peut grandement réduire la détérioration des sols organiques.

II y a peu de zones humides sur le plateau Intéreur et dans les montagnes du Sud. Celles des basses altitudes, qu'on trouve dans les grandes vallées, peuvent servir á la production horticole et fourragère même si les étés y sont particulièrement secs, á condition de bien gérer le régime hydrologique. Aux altitudes plus élevées et sous des climats plus rudes, on ne cultive que des plantes fourragères indigènes pour nourrir le bétail.

Dans les zones humides des montagnes du Nord, de la région de Nord-Ouest, de la plaine de la Liard et des basses-terres de Fort Nelson et de la rivière de la Paix, le climat n'est en général propice qu'à la culture des plantes fourragères, parce que les températures fraîches ne réchauffent pas les sols saturés d'eau assez rapidement pour éliminer les risques de gel liés aux basses altitudes. Les fourrages qu'on y récolte servent principalement à l'alimentation des chevaux des pourvoyeurs et guides. 


\section{INTRODUCTION}

\subsection{Definition}

Wetlands referred to in this report are those "dominated by the persistent presence of excess water" (Zoltai 1988). Tarnocai (1980) provided an expanded definition of wetland as "land that has the water table at, near, or above the land surface or which is saturated for a long enough period to promote wetland or aquatic processes as indicated by hydric soils, hydrophytic vegetation, and various kinds of biological activity that are adapted to the wet environment". Unlike many other ecosystems, wetlands are found in all parts of the nation; offer unparalleled and highly diverse values for biological, hydrological, ecological and socioeconomic purposes; are often critical to the livelihood of many Canadians; and are strategically important in sustaining biological life.

\subsection{Purpose and Background}

Wetlands are recognized as a renewable resource with values that include habitat for a wide variety of wildlife, recreation opportunities in unique ecological systems, regulation of water regimes, production of timber and production of horticulture and forage crops in suitable climates (Rubec et al. 1988). Although these values are recognized, the areal and altitudinal distribution and extent of wetlands in British Columbia (BC) are less well defined. The purpose of this study is to summarize the area occupied by wetland, compiled from available sources, in map and tabular form by elevation categories, to provide an overview on a province-wide basis that may be useful for assessing wetland values. Special reference to literature relating to agricultural uses is made.

Large areas of wetlands in the Chilcotin-Cariboo region, centering around Williams Lake, were recognized for their natural forage production value following the fur trade and gold rush periods. Ranches were established in the late 1800's and early 1900's to utilize the most productive and accessible wetlands adjacent to grassland range for beef cattle production (Weir 1964). About one-half of the grazed forage and stored winter feed was estimated to be produced on wetlands in this region (C.F. Cornwall, retired District Agriculturist, Williams Lake, personal communication).

$\mathrm{BC}$ produces about $5 \%$ of Canada's beef cattle, a disporportionate share in relation to $\mathrm{BC}$ 's human population, about $10 \%$ that of Canada's. About one-half of $B C$ 's beef cattle is produced in the southern interior (east of the Coast Mountain divide). One-half again of that is produced in the Chilcotin-Cariboo.

Significant areas of wetlands are cultivated for forage and horticultural crops in the lower Fraser Valley (Luttmerding 1981a) and on southern Vancouver Island (Maas 1972). Wetlands in the northern half of BC are usually not cultivated for any crop, including forages, but may supply grazing or browsing for wildlife or domestic horses and cattle, mainly for guide outfitters.

Maynard (1988) notes that, although drainage is necessary to lower the water content of the upper layers of peat (organic deposits) sufficiently to lower it's water content to provide a surface firm enough to carry production equipment for either mining or farming, evaluation of the environmental impact should include such items as local hydrogeology and groundwater, drainage 
rates, radius of influence of the lowered water table, and quality of the drained water. Furthermore, developers should be required to carry out environmental and socioeconomic studies to justify the worth of a peat harvesting operation in comparison to the value of retaining the peatland in its natural state for wildlife habitat, water regulation, recreational opportunities and/or aesthetic purposes. Similarly, evaluation should be made of possible environmental problems caused by agricultural use, such as contamination of groundwater and surface runoff water from applications of lime and fertilizer.

\subsection{Wetland Formation}

Wetland formation is dependent on several climatic factors. Organic wetlands occur in areas where precipitation plus water inflow is greater than evaporation plus runoff, creating a positive water balance. Under these conditions, organic material derived from vegetation accumulates when its rate of accumulation is greater than its rate of decomposition. Where temperature is so low that precipitation falls mainly as snow, glacier formation is favored but vegetation growth is not, so little organic material accumulates. Under high temperature, such as occurs in the tropics, vegetation growth is favored but the rate of decomposition is rapid so that accumulation of organic matter is low. Under moderate temperatures, decomposition is slower so organic matter accumulation is significant. In Canada, most wetlands have formed since the end of the last ice age well after the continental and Cordilleran ice sheets melted in response to warming climate during the period of about 13000 to 8000 years ago. Significant peat formation did not occur until the large areas inundated by glacial lakes had been partially drained by rivers establishing an effective drainage system, oceanic inundation was reduced by isostatic rebound of submerged land, and after the warm, dry Hypsithermal period terminated about 4000 to 5000 years ago, particularly in the south (Zoltai 1988).

Organic deposits occur in topographic depressions, along drainage ways, especially those on nearly level areas with poorly organized drainage systems, and also on slopes where precipitation is high and evaporation is low, such as along the windward coast of BC. Dam building activities of beavers in some areas have enhanced wetland formation in the past and are again becoming a significant influence. Terasmae (1977) and several authors (National Wetlands Working Group [NWWG] 1988) provide more detailed discussions of wetland formation in Canada. 


\section{CANADIAN WETLAND CLASSIFICATION SYSTEMS}

\subsection{Wetland Classification Systems}

In Canada, wetlands have been classified by two systems. Historically they have been included in the Canadian System of Soil Classification (Agriculture Canada Expert Commitee on Soil Survey [ACECSS] 1987) as it was developed by the Agriculture Canada, Research Branch in cooperation with provincial counterparts. More recently, Environment Canada, Lands Directorate has sponsored the development of a Canadian Wetland Classification System in cooperation with other agencies, including the Research Branches of Agriculture Canada and Forestry Canada (NWWG 1987). The Canadian National Topographic Map Series (NTS) includes an undifferentiated "marsh" (swamp) category.

Other wetland classification systems have been developed in $\mathrm{BC}$ but relate specifically to the Chilcotin-Cariboo region and have not been used for extensive mapping of wetlands. Terrain and surficial geology classifications and maps prepared by BC Ministry of Environment and Environment Canada, Geological Survey of Canada include the "Organic Deposit" category.

\subsection{Canadian Soil Classification}

Wetland soils have been classified as members of the Cryosolic, Gleysolic and Organic soil orders (Appendix 9.1) of the Canadian System of Soil Classification (ACECSS 1987). Organic soil classification is based on characteristics of the control section (160 cm depth). These soils are classified into three soil great groups, Fibrisol, Mesisol and Humisol, based on increasing degree of decomposition of the organic material in the middle tier (40 to $120 \mathrm{~cm}$ depth) or in the middle and surface tiers, if the organic material is less than $120 \mathrm{~cm}$ in depth. By definition, Organic soils must have an accumulation of organic material, containing $17 \%$ organic carbon or more by weight, that is at least $60 \mathrm{~cm}$ thick for Fibrisols and $40 \mathrm{~cm}$ for Mesisols and Humisols.

Soils of the Folisol Great Group of the Organic Order (ACECSS 1987) are not included in this study. The folic organic material of this great group is generally of forest origin, at least $10 \mathrm{~cm}$ thick, and rarely water saturated. Folisols often occur on upper slope, water shedding positions in cool, moist, humid forest ecosystems, particularly on the west coast of $\mathrm{BC}$ where the surface folic material commonly exceeds $40 \mathrm{~cm}$.

Gleysolic soils may have organic layers, thinner than those required for Organic soils, overlying mineral substrata. These occur commonly in shallow depressions or on level lowlands and have features that are indicative of prolonged or periodic saturation with water leading to reducing conditions because of lack of oxygen. Three great groups are defined based on characteristics of the mineral substratum. The Humic Gleysol has a humus enriched Ah horizon that is more than $10 \mathrm{~cm}$ thick while the Ah of the Gleysol, if present, is less than $10 \mathrm{~cm}$ thick. The Luvic Gleysol has an underlying clay enriched horizon. Dull gray to greenish-gray colors of Gleysolic soils are attributed to reduction of iron compounds resulting from prolonged saturation. Prominent reddish mottles, developed during periodic drying, are due to oxidation of iron compounds.

Cryosolic soils have permafrost near the surface and may be formed on either mineral or organic material. Organic Cryosols are reported to occur in the extreme northeast of $\mathrm{BC}$. These 
soils have an active layer (summer thawed) above permafrost, that is about $50 \mathrm{~cm}$ thick near the Northwest Territories border and deeper, between 1 and $2 \mathrm{~m}$, at their southern extremity (NWWG 1986). Gleysolic Cryosols may occur in association with Organic Cryosols.

The publication "Soil Landscapes of BC" (BC Ministry of Environment [BCME] 1978b) presented an extensive overview of the nine Canadian soil orders occurring in $B C$, including the Organic, Gleysolic and Cryosolic Orders. The authors used a pedological landscape approach with a minimum of technical terms. The development of $\mathrm{BC}$ soils was explained in relation to climate, geology and geological materials, physiography and vegetation for five regions, based on physiographic subdivisions. Historical aspects of BC Soil Canada Land Inventory (CLI) and Terrain surveys were presented by several authors (BCME 1978b, Part 4).

Farley (1979) presented a soil map, based on the Canadian System, of BC (approx. 1:6 500000 scale) indicating that Gleysols dominate on the floodplain and delta of the Fraser River west of Agassiz, the Kootenay Valley south of the inlet of Kootenay Lake near Creston, the Pemberton Valley, and a large portion of the upper Columbia Valley north and south of Golden, $5115 \mathrm{~N} 11700 \mathrm{~W}$ (51 $1^{\circ} 5^{\prime}$ North Latitude, $117^{\circ} 00^{\prime}$ West Longitude). Organic soils dominate on gently sloping areas along the north coast of BC south of Alaska, and on the north end of the Queen Charlotte Islands, while Organic Cryosols and Gleysols dominate in the extreme northeast of $\mathrm{BC}$ (Fort Nelson Lowland).

More precise definitions of the great groups of the Cryosolic, Gleysolic and Organic and respective subgroups and phases have been reported by ACECSS (1987). These definitions, as well as those of well-drained soil orders in the Canadian Classification System, are the basis by which soil surveys classify, describe and map soils, including those for surveyed areas of $B C$. Agriculture capability maps were derived by the joint federal provincial CLI program (Environment Canada, Lands Directorate 1970, 1976) from soil survey information and summarized for BC by BCMAFF (1976).

\subsection{Canadian Wetland Classification}

A Canadian Wetland Classification System has been prepared by the NWWG (1988) and discussed by Zoltai (1988) which represents a synthesis of existing systems at the national level and in this context was defined by Tarnocai (1980). Wetlands include organic wetlands (peatlands) characterized by more than $40 \mathrm{~cm}$ of peat accumulation on which organic soils develop; and mineral wetlands characterized by areas of Gleysols or peaty phases of Gleysols, or areas of shallow open water generally less than $2 \mathrm{~m}$ deep. The Canadian Classification System contains three hierarchical levels: class, form and type (NWWG 1987). The five wetland classes: bog, fen, marsh, swamp and shallow open water are recognized on the basis of the overall genetic origin of wetland ecosystems. Seventy wetland forms are differentiated on the basis of surface morphology, surface pattern, water type and the morphology of the underlying mineral soil. Wetland types are classified according to vegetation physiognomy. General descriptions of the five wetland classes and classification keys differentiating the wetland forms of each class (NWWG 1987) have been excerpted (Appendix 9.2).

A wetland region map folio (NWWG 1986) of Canada with expanded legend has been prepared based on the Canadian Wetland Classification System. Two maps, 1:7 500000 scale, present categories of wetland density and of wetland regions and/or region subdivisions (WR), respectively. A special interim report with maps "Peatlands of the Pacific Coast of British 
Columbia", was prepared using aerial and Landsat imagery complemented by field inspection, sampling and analysis (Dendron Resource Surveys Ltd. [Dendron] 1985) and is based on the NWWG (1988) system.

\subsection{National Topographic Map Series Classification}

For areas that have not been surveyed and mapped for soil or CLI, NTS maps provide a limited measure of information on wetland distribution. The undifferentiated "marsh" (or "swamp") category indicates wetland, usually interpreted from aerial photographs. 


\section{OTHER CLASSIFICATION SYSTEMS}

The BCME Assessment and Planning Division, as well as the Geological Survey of Canada, have published several studies on surficial geology and/or terrain analysis. These studies include descriptions of, and maps indicating locations of, organic deposits. Poorly drained mineral areas however are not delineated. Data from these publications were not used for the compilation of wetland area but reference is made in this text to certain of these studies where soil-CLI data is lacking.

Beets and Sidney (1975) compiled an inventory of all of the 564 wetland map polygons ( $80 \%$ are 24 to $240 \mathrm{ha}$ ) within a defined area surrounding Williams Lake showing CLI capabilities for agriculture, waterfowl, ungulate and forestry uses. This report reflected the growing need to gain more information on wetland characteristics relevant to a growing number of perceived and conflicting uses, particularly in the Chilcotin-Cariboo area of B.C. The authors recommended the continuance of a moratorium, already in place, on further tenure alienation of meadows (wetland and adjacent land transitionary to uplands) until further indepth studies could be carried out to define the relevant characteristics and lead to a practical system to classify these lands for various uses.

Selby (1983) summarized the then current wetland studies in BC. Specific inventories are conducted by Ducks Unlimited (Canada) for certain attributes of wetlands that are significant for waterfowl use. Runka and Lewis (198I) prepared a preliminary wetland managers' manual for trial use in the Chilcotin-Cariboo area of BC. They presented a hierarchical classification of seven wetland classes: shallow open water, marsh, fen, bog, swamp, shrub-carr and meadow. These classes were divided into subclasses and variants based on soil and water attributes.

Moon and Selby (1983) further developed a wetland classification consisting of nine wetland systems composed of recurring combinations of individual classes, defined on the basis of vegetation and soil components to be used for mapping and management purposes also based on field work in the Chilcotin-Cariboo. Selby and Moon (1988) presented a hydrologic model that explains how water regime influences vegetation zonation. The model offers a framework for evaluating the development of wetlands that, with further testing, may provide a useful tool for wetland management. Fenger (1987) has proposed a multi-agency inventory for CaribooChilcotin wetlands.

The Runka and Lewis (1981) and Moon and Selby (1988) classifications relate only to the Chilcotin-Cariboo region of $\mathrm{BC}$ and have not as yet been used for formal mapping of wetlands. However, the BCME Fish and Wildlife Branch has adapted the Runka and Lewis (1981) system for defining wild ungulate habitat. This system is still in use by the Williams Lake offices of the BCME Fish and Wildlife Branch and of Agriculture, Fisheries and Food (BCMAFF) for site-specific assessments of wetlands.

Guides to wetland ecosystems were prepared by Roberts (1984) for the Sub-boreal Spruce Biogeoclimatic Zone (BGCZ) (see below) and by Steen and Roberts (1988) for the Interior Douglas-fir BGCZ of the Cariboo Forest Region (BC Ministry of Forests [BCMF]) using the approaches of Runka and Lewis (198I) and Moon and Selby (1983).

A biogeoclimatic ecosystem classification has been presented on a revised BGCZ map (scale 1:2 000000 ) (BCMF 1988) to aid in forest and range management. The $14 \mathrm{BGCZ}$, each named 
for its dominant vegetation species, are based on the system of Krajina (1965) and developed further by Pojar et al. (1987).

Within the BGCZ, there are subzones and/or variants, defining ranges of different ecosystems, which have been classified and presented in field guides and reports. A twodimensional edatopic grid, used to define these ranges or ecosystem site units, utilizes a range of soil moisture regimes (very dry to very wet) along one axis and of soil nutrient regimes along the other. Wetlands occur within the moist (subhygric) to very wet (subhydric) moisture regimes. The ecosystem site units are used to prepare management interpretations for silviculture, wildlife and recreation.

The 14 BCGZ may be grouped into five broad categories as follows:

Coastal (dry/wet) Three BGCZ, Coastal Douglas-Fir, Coastal Western Hemlock and Montane Hemiock (subalpine) are distributed, generally in that order, with increasing elevation, north latitude and wetness in the Georgia and Hecate Depressions, the Insular Mountains, and the windward (west) side of the Coast Mountains.

South Interior (dry) Six BGCZ, Bunchgrass, Ponderosa Pine, Interior Douglas-Fir, Montane Spruce, Engelmann Spruce - Subalpine Fir, and Sub-boreal Pine - Spruce are distributed, generally in that order, with increasing elevation, north latitude and wetness from the bottoms of the major valleys to the plateaux, highlands and adjacent mountains south of about $5300 \mathrm{~N}$.

Interior Mountains (wet) The Interior Cedar - Hemlock BGCZ occupies the wet windward (west) side of the Columbia Mountains in southeastern BC as well as the Hazelton Mountains and the southwestern portion of the Skeena Mountains and the Nass Basin in west-central $B C$.

Central and Northern The Sub-boreal Spruce BGCZ lies in the plateaux, basins, plains and highlands north of about $5700 \mathrm{~N}$ on the east side of the Coast Mountains and extends into the valleys of the Rocky Mountains. The Engelmann Spruce - Subalpine Fir BGCZ lies above this BGCZ extending into the area of this category from the South Interior (dry). The Boreal White and Black Spruce BGCZ occupies the bottoms of the major valleys north of $5700 \mathrm{~N}$ and on the Liard and Alberta Plateaux and is replaced by the Spruce - Willow - Birch BGCZ at higher elevations.

Alpine The Alpine Tundra BGCZ occupies positions near the top of all high mountains adjacent to the subalpine BGC zones and subzones.

A fifteenth category, glaciers and ice fields, occupies the topmost positions of the highest mountains, generally dominant on northeast-facing slopes and cirque valleys.

A broad view of vegetation distribution is shown by the elevational position of the upper treeline (diffuse boundary between Subalpine and Alpine Tundra BGCZ). This boundary increases generally from northwest to southeast ( 900 to $2100 \mathrm{~m}$ ) and from southwest to northeast $(1000$ to $1500 \mathrm{~m})$ as estimated for north facing slopes across the approximate geographic centre of BC. The treelines on south facing slopes are generally higher because of warmer microclimates. A similar relationship can be shown for the lower treeline (diffuse boundary between Bunchgrass and Interior Douglas-Fir). 
Tree vegetation on wetlands is generally curtailed because of cold soil temperatures, excessive moisture or lack of aeration. In many of the drier zones, fen wetlands are dominated by sedge and grass forage species and shrub browse species that respond to the richer nutrient regimes. Mosses tend to dominate on wetlands in zones of higher precipitation. Wetland formation is related more to water regime than to regional climate. However the BGCZ descriptions do provide an assessment of growing season climate and give some indication of the agricultural crop productivity that may be expected. For operational management of specific sites, these classifications are presented on more detailed biogeoclimatic maps (scale 1:100 000 to 1:500 000) which, along with the field guides and reports, are available from the various BCMF Regional offices. 


\section{METHODS}

\subsection{Map Sources}

Wetland areas were recorded, originally by acre units, from various available map sources (Fig. 1) covering all of $\mathrm{BC}$ by individual map areas, $0015 \mathrm{~N}$ by $0030 \mathrm{~W}$ ( $0015 \mathrm{~N}$ latitude by $0030 \mathrm{~W}$ longitude) according to the grid notation for the NTS map series for Canada. The data for each map area were listed by $300 \mathrm{~m}$ (1000 ft) elevation intervals and by wetland categories, as wetland Organic or Gleysolic, where provisional and/or published soil or CLI agriculture capability maps were available; or Marsh (swamp) as total wetland derived from the category of NTS maps where neither soil nor CLI were available. The data are presented here in metric units, elevation categories to the nearest $100 \mathrm{~m}$ and area to the nearest square kilometer. They are also summarized by $0100 \mathrm{~N}$ by $0200 \mathrm{~W}$ map areas (Appendix 9.3).

Map polygon areas on CLI maps indicated as organic (O) and with wetness limitation (W) were recorded as Organic, while those with $W$ limitation but not $O$ were recorded as Gleysolic. However, if $W$ was combined with the topographic limitation $(T)$, considered to indicate a gleyed member of a non-Gleysolic soil subjected to aerated waters, the polygon area was not recorded. Areas of wetland soil were taken directly from microfiche copies of the original planimetered provisional CLI maps, 1:50 000 scale. One published CLI series (82 G, l:I 257000 scale) and unplanimetered provisional copies of CLI maps for coastal and north western map areas were obtained and map polygons were planimetered using an electronic graphics calculator (dot planimeter with totalizing feature). Published CLI Soil Capability for Agriculture maps with legend may be available from Maps BC, BC Ministry of Crown Lands, Victoria or from Environment Canada, Ottawa.

Organic and Gleysolic soil areas indicated on provisional or published (Fig. 1) soil survey maps, and on one published biophysical (part of $93 \mathrm{H}$ ) map, (usually l:125 000 scale) were also estimated by dot planimeter. Polygons containing gleyed members of non-Gleysolic soil orders were not recorded. Soil survey maps not included with soil survey reports, in the final draft or published form are so indicated under literature cited.

The proportion of each component in multiple component map polygons was indicated on CLI and on most soil maps. The area of wetland soil represented in these polygons was calculated. Where proportions were not given, the first named (dominant) soil was recorded to represent the polygon.

NTS maps (usually l:250 000) were used for areas of the province not covered by CLI or soil maps. The area of wetland indicated by marsh designation was estimated by dot planimeter and considered as total wetland. Coastal wetlands had not been surveyed at the time of this compilation. However, their maximum estimated extent was delineated on NTS maps, generally at $300 \mathrm{~m}$ elevations (T.M. Lord, personal communication). This area was arbitrarily recorded as $100 \%$ organic wetland for computer purposes and designated as Coastal Slope bog. Thus, the area of wetland for these coastal wetlands was grossly overestimated by this method.

Total land area covered by planimetered CLI map areas was taken from microfiche copies of original draft CLI maps as the total planimetered area of each map area which included water bodies and unclassified areas. It was assumed that this procedure would give truer values for percent of wetland than using tabled values. These total areas usually differed by less than $1 \%$ 
from tabled values, supplied by BC CLI staff, for corresponding map areas. Total land area for published CLI ( $82 \mathrm{G}$ ), soil surveyed and NTS map areas south of $5500 \mathrm{~N}$ were taken from the total area by planimetery of the nearest adjacent provisional CLI map area at the same latitude. Total land area for all map areas north of $5500 \mathrm{~N}$ were taken from tabled values. The total land area was estimated by dot planimeter only for those map areas that contained recorded wetland area and were bisected by irregular boundaries with Alaska, Alberta or the Pacific Ocean. These totals were used for calculation of percent of total land area occupied by the wetland categories for each map area.

\subsection{Data Treatment}

Data were entered into the computer by NTS map designation. The percent of wetland in each elevation and wetland category was computed for each map area. Isoline maps depicting distribution of wetland density as percent of total land area were then generated by a computer program for all elevation and wetland categories and for certain combinations of elevational categories. Certain of these maps were manually transferred to NTS base maps of BC for total wetland density (Gleysolic plus Organic, or Marsh) and for total Gleysolic wetland density (CLI and soil surveyed area) for each of three elevation categories; all elevations (Fig. 2 and 3 , respectively), 300 to $600 \mathrm{~m}$ (Fig. 4 and 5, respectively) and 600 to $1200 \mathrm{~m}$ (Fig. 6 and 7 , respectively). These six figures were drafted and printed by the Information Systems and Cartography Unit, Land Resource Research Centre, Research Branch, Agriculture Canada, Ottawa.

All of the figures, depicting the map of BC, were closely adjusted to a scale of $1: 8000000$ scale. This allows the reader to photocopy any figure onto a transparent sheet which may be superimposed on any other for the purpose of making direct comparisons. Indeed, certain printing shops and/or office equipment stores now have photocopiers with exchangeable colour cartridges. The $0200 \mathrm{~N} \times 0400 \mathrm{~W}$ intersect points can be used to align coincident portions of the maps in order to mitigate small errors of scale. The wire-o binding allows this bulletin to lie flat for this purpose.

Wetland areas for BC were summarized by total wetland (Organic and Gleysolic soils and Marsh), total Organic and total Gleysolic soil wetlands, and by elevation categories. The total land area of BC was taken as $948600 \mathrm{~km}^{2}$ (Farley 1979) and used to calculate total BC wetland $(5.6 \%)$.

Total wetland areas were summarized (Table 1) by nine selected groups of physiographic subdivisions (Holland 1976) delineated to the nearest $0015 \mathrm{~N} \times 0030$ map area boundary (Fig. 8, Table 1). These are subdivisions of the western, interior and eastern systems of the Canadian Cordilleran and of the Canadian Interior Plains physiographic regions described by Holland (1976).

The boundary for the Hecate Depression subdivision group extends somewhat beyond that of Holland (1976). However, this extension facilitated the use of data given by Dendron (1985) for compiling areal values for the 0 to $300 \mathrm{~m}$ elevation category for the Hecate Depression (Table 1). The relevant NTS map sheets used were $92 \mathrm{~L}$ and $M, 102$ I (estimated), $102 \mathrm{P}, 103 \mathrm{~A}, \mathrm{~F}, \mathrm{G}$, $\mathrm{H}, \mathrm{J}$ and K. Dendron (1985) listed $1912 \mathrm{~km}^{2}(24 \%)$ of peat landforms compared to $8098 \mathrm{~km}^{2}$ ha for the present study where $100 \%$ Organic wetland area was arbitrarily assigned to the land area below $300 \mathrm{~m}$ elevation. 


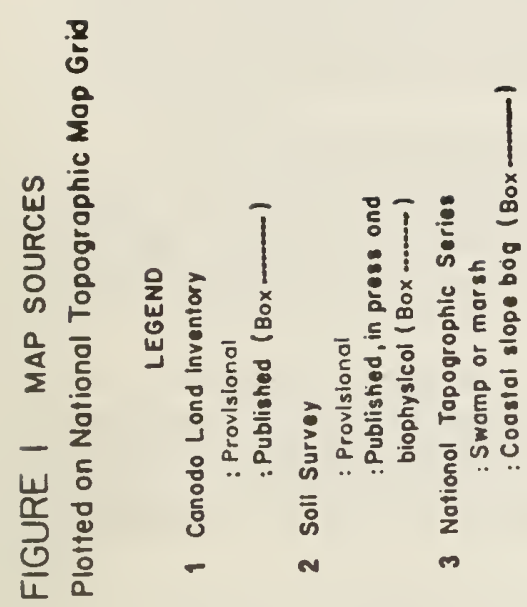

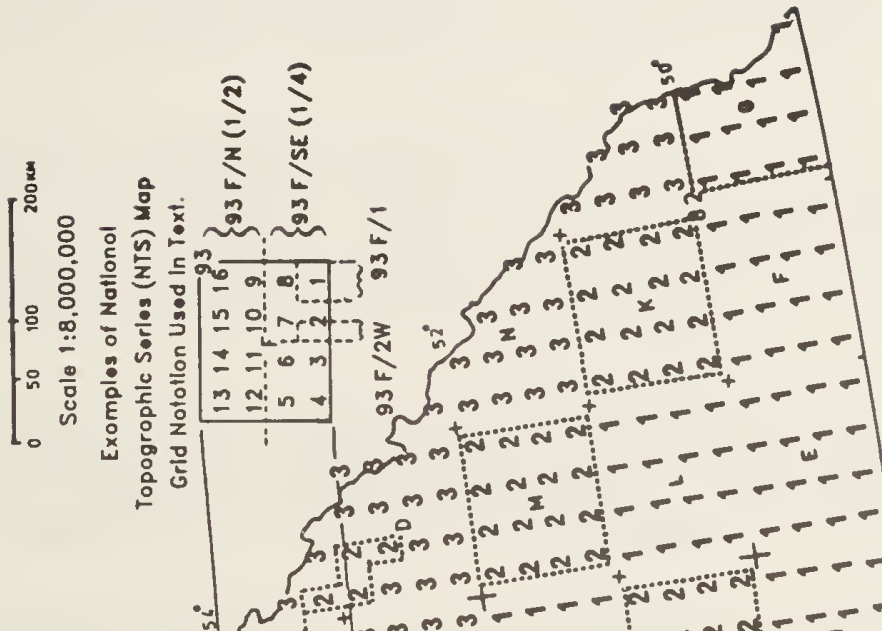

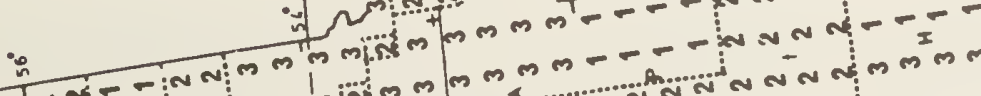
-

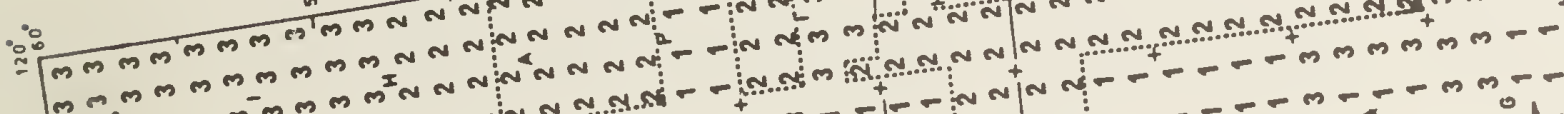

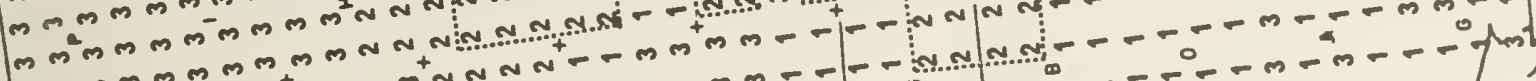

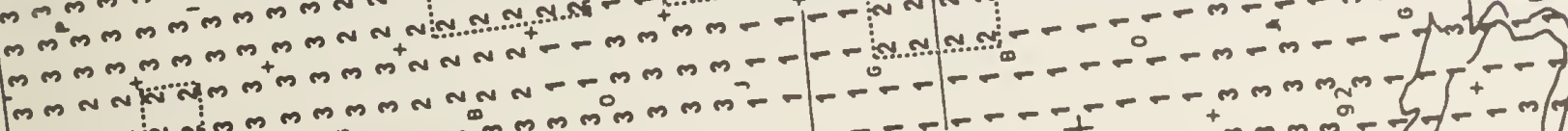
m ñ

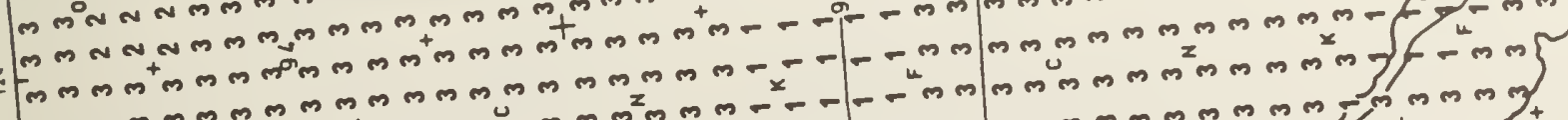

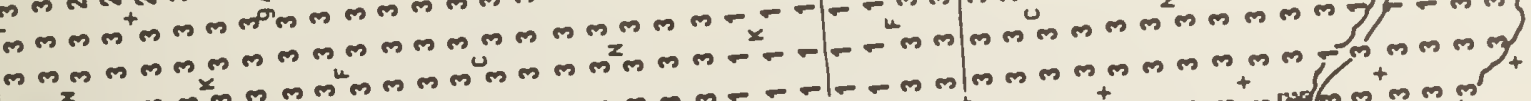
作

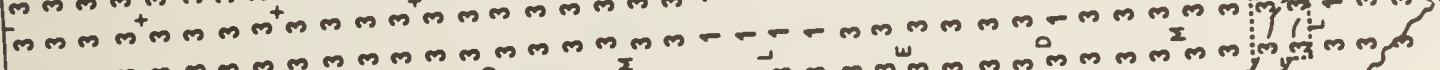

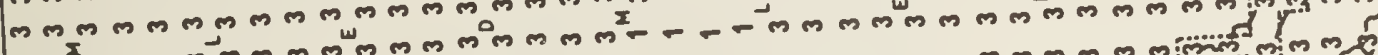

-

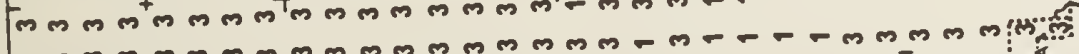

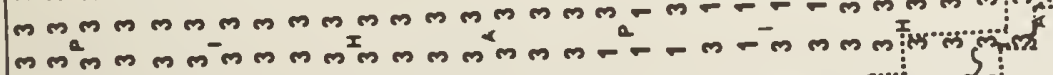
m

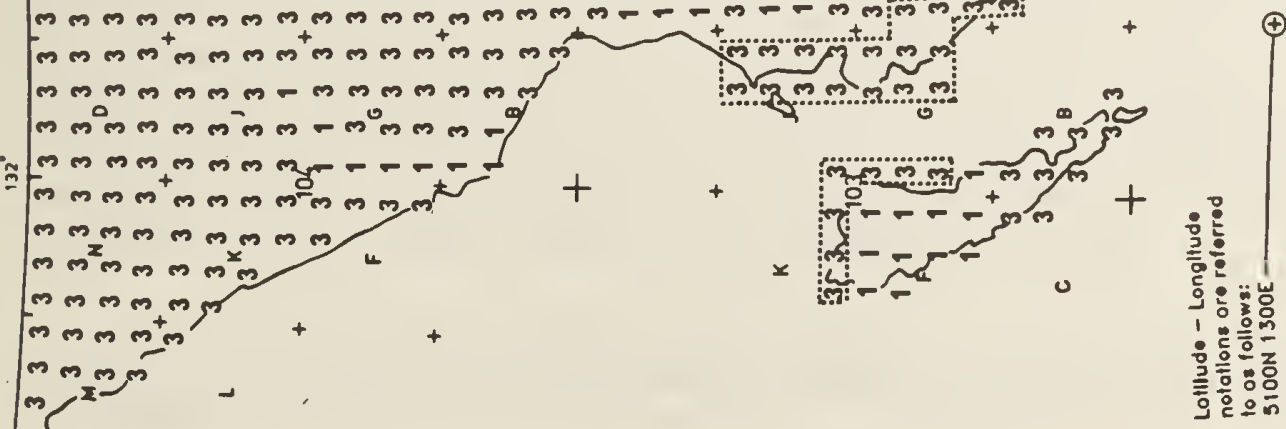


4. Methods 
Total land area for the Mountain subdivision group (Table 1) was calculated by subtracting the total land area for all other subdivision groups from that for BC $\left(948600 \mathrm{~km}^{2}\right)$ because map areas at the irregular boundaries of $\mathrm{BC}$ for which no wetland was shown were not planimetered. Further tabular summaries relating to certain physiographic subdivision groups are included throughout the following text.

Four selected east-west transects across BC were diagrammed to indicate certain major features of wetland distribution and extent (Fig. 9). The percentage of wetlands indicated for Hecate Depression on the $5400 \mathrm{~N}$ cross section was estimated by taking $24 \%$ of the wetland assigned to Coastal Slope bog below $300 \mathrm{~m}$ (see 4.3 Reliability and Errors).

The wetland areal data were further summarized according to 0100N 0200W NTS map area and to the elevation categories (Appendix 9.3). The areal values for Marsh (NTS) wetlands were added to those for the combined Organic and Gleysolic wetlands to provide the total wetland category in addition to separate Organic and Gleysolic wetland categories.

A copy of the original computer printout listing, with an explanation of the coding, is stored at the Research Station, Agriculture Canada, Kamloops along with a limited number of copies of this bulletin, both of which will also be stored with Maps BC, Ministry of Crown Lands, Victoria; Pedology Unit, Land Resource Research Centre, Agriculture Canada, Research Branch, Vancouver, BC; and Geographic Information Centre, Department of Geography, University of BC.

\subsection{Reliability and Errors}

The NTS maps are probably the least reliable for estimation of wetland area, particularly under forest or alpine vegetation, because field checking would be limited and the map scale was small (I:250 000). A study of peat resources (Maynard 1988) included data from more recently published surficial geology, terrain and soil maps as well as certain data from this present study. D.E. Maynard (personal communication) indicated that small scattered areas of organic soil occur along valleys that do not appear on certain NTS maps.

Significant areas of Organics were indicated for the Manson River-Fort Fraser (Epp and Kenk 1983; $94 \mathrm{~N}$ and $\mathrm{K} / \mathrm{N}$ ) and Hazelton map areas (Wittneben 1984, $93 \mathrm{M} / \mathrm{N}$ ) which were not available for this study. The study of coastal peatlands (Dendron 1985) indicated a wetland area of about $24 \%$ of that arbitrarily recorded as Coastal Slope bog (Fig. 2) for corresponding map areas in this present study. The soil survey of the upper part of the Fraser Valley (Hortie et al. 1970) was conducted along the main valley of the Fraser River. Data from NTS maps for uplands adjacent to the main valley for certain of those map areas (parts of $83 \mathrm{D}$ and $\mathrm{E}, 93 \mathrm{H}$ and I) were used to supplement data, as marsh category for the Organic soil wetlands.

Known errors, that were not corrected because of computer and time constraints before printing, are noted on copies of the computer listing. Most minor errors occurred where wetlands occupied less than $2 \%$ of the land area.

Known significant errors are noted here. Data for $93 \mathrm{H} / 11$ and $93 \mathrm{H} / 4$ appear to be interchanged and data for Gleysols on map areas $92 \mathrm{P} / 6,11,13$ and 14 are underestimated. Gleysols for $94 \mathrm{~J} / \mathrm{NE}$ were underestimated by a factor of about $5,2 \%$ compared to $10 \%$ of total map area. Only organic areas were estimated for 94 1/9-16 from biophysical maps. 
The map sheets $83 \mathrm{E} / 3,93 \mathrm{H} / 1,2,7$ and 9 should not have been included as map sources for Gleysolic soils (Fig. 3, 5, 7); their source was NTS maps. Gleysols for $82 \mathrm{M}$ were estimated from CLI maps but Organics were estimated from a published soil map (Kowall 1980).

Wetland area values reported for soil surveyed map areas may not coincide exactly with those reported in corresponding soil survey reports, possibly because of differing methods of compilation and presentation of multiple component map polygons or of accuracy of planimetering. 


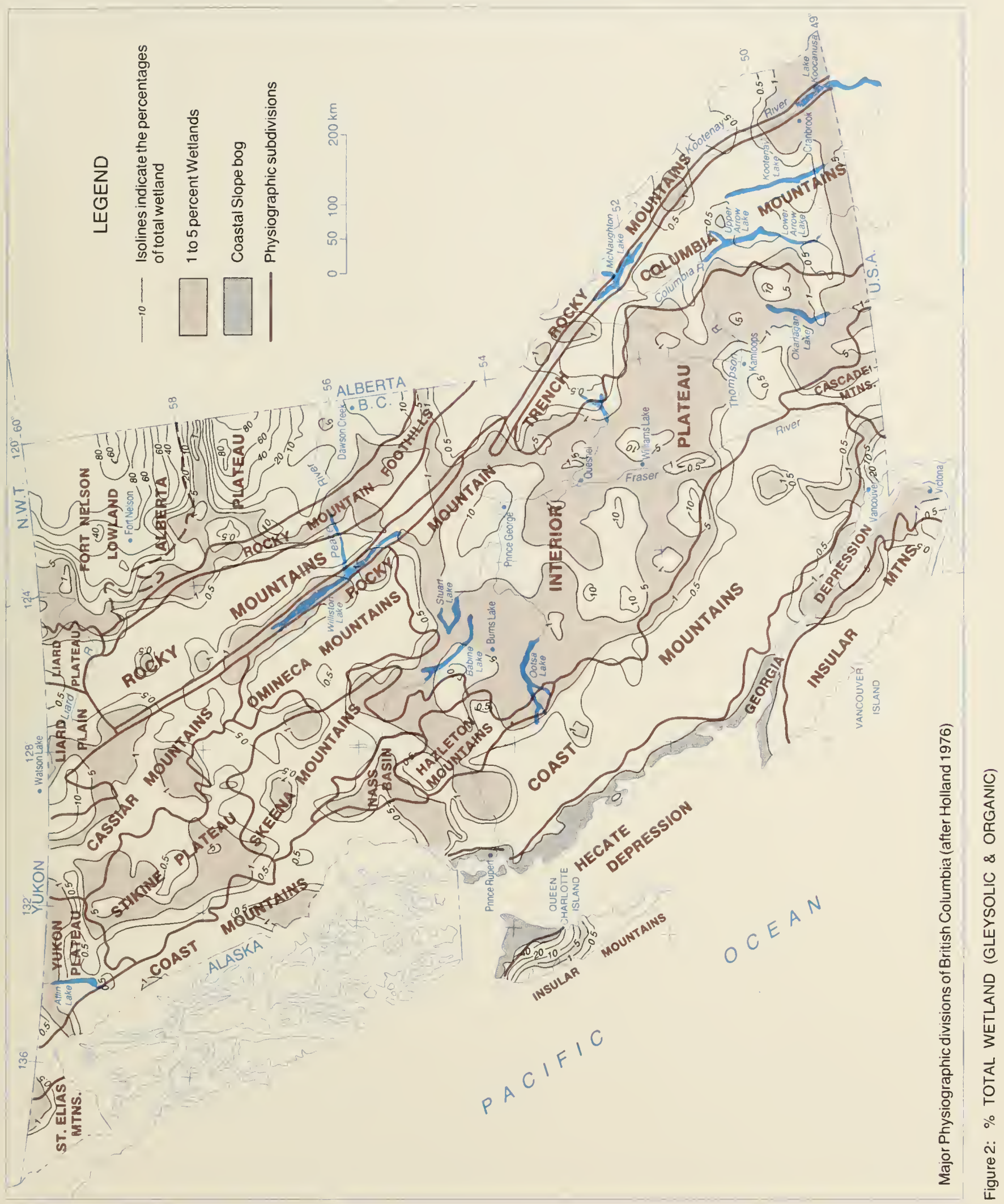





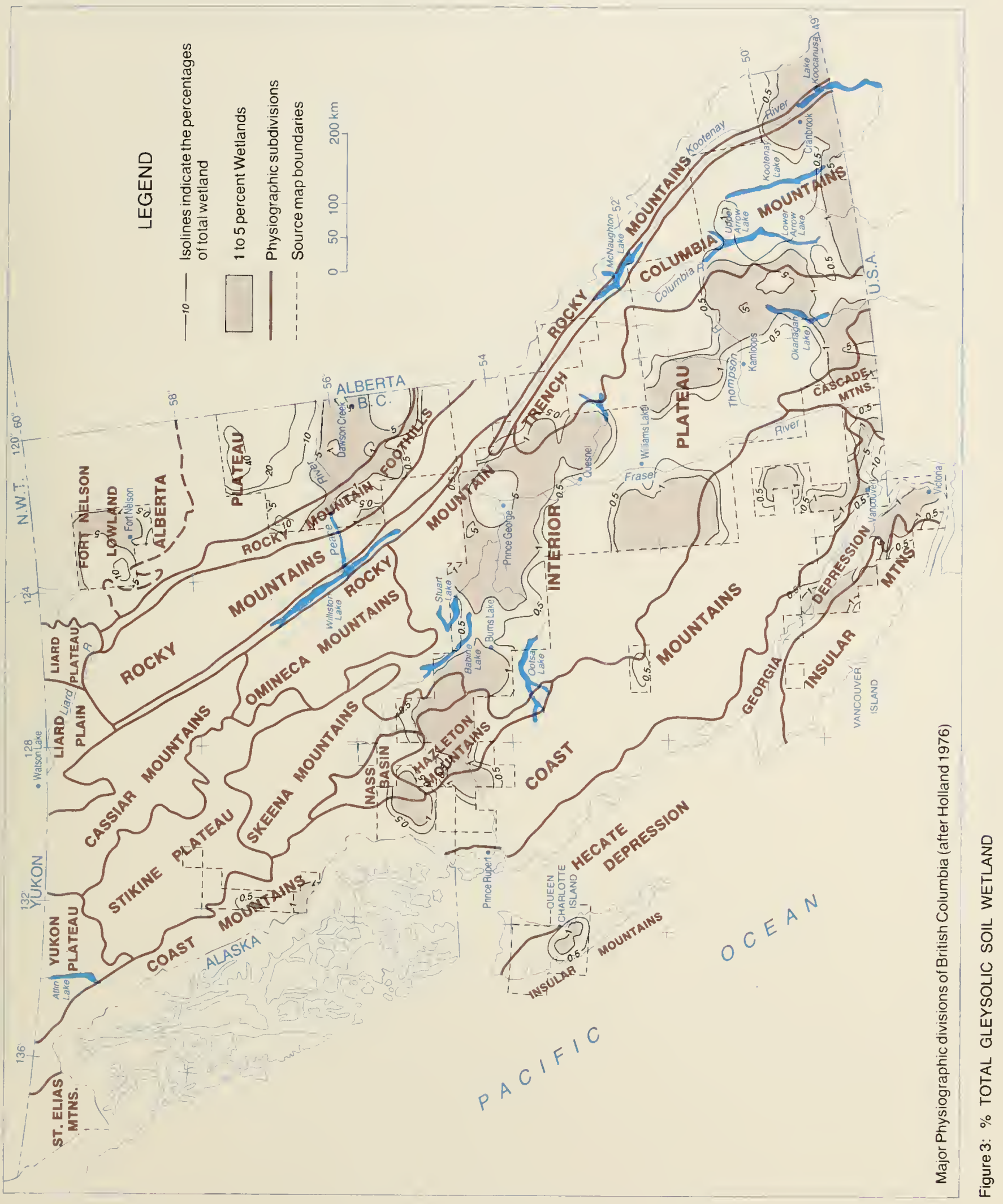





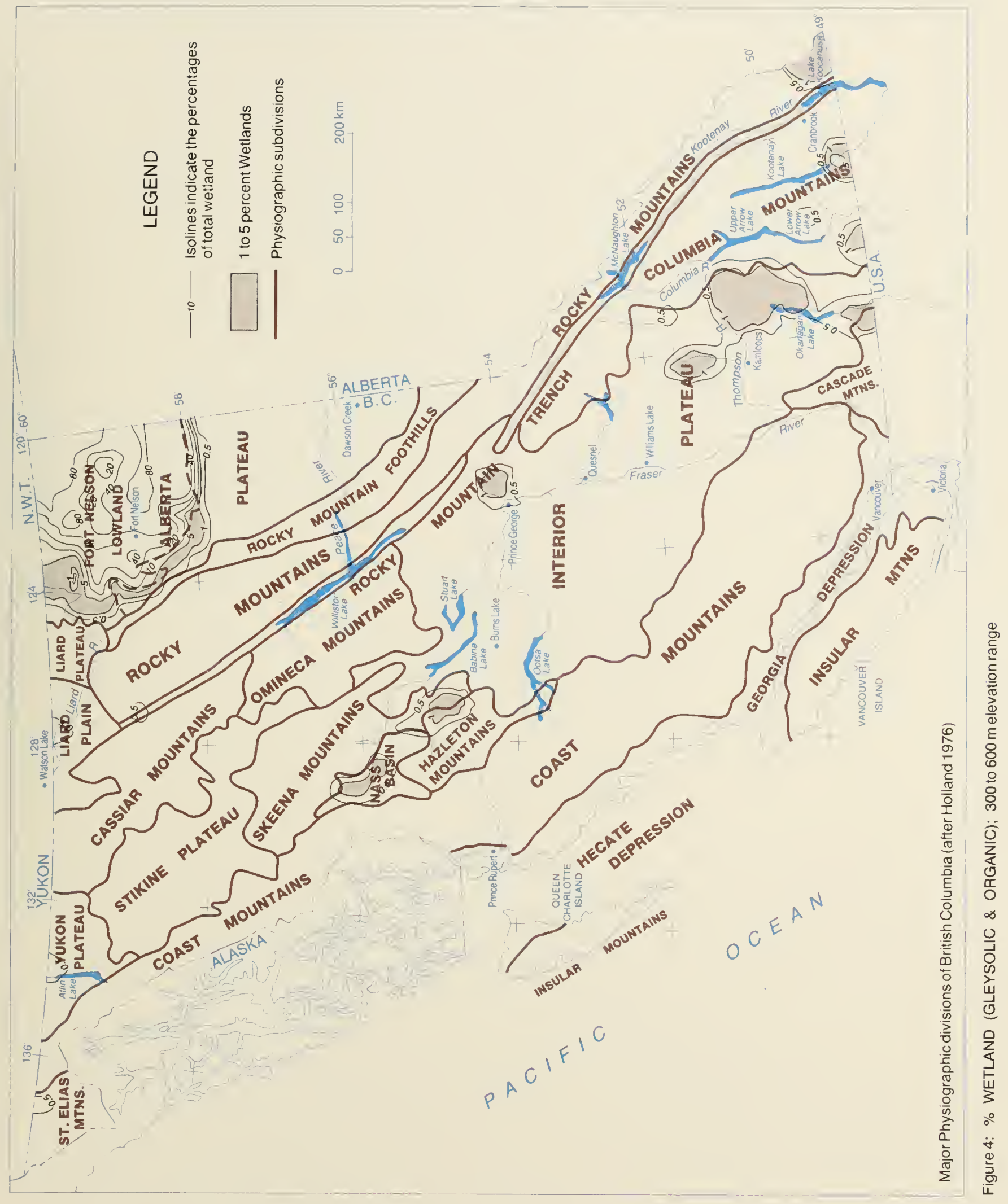





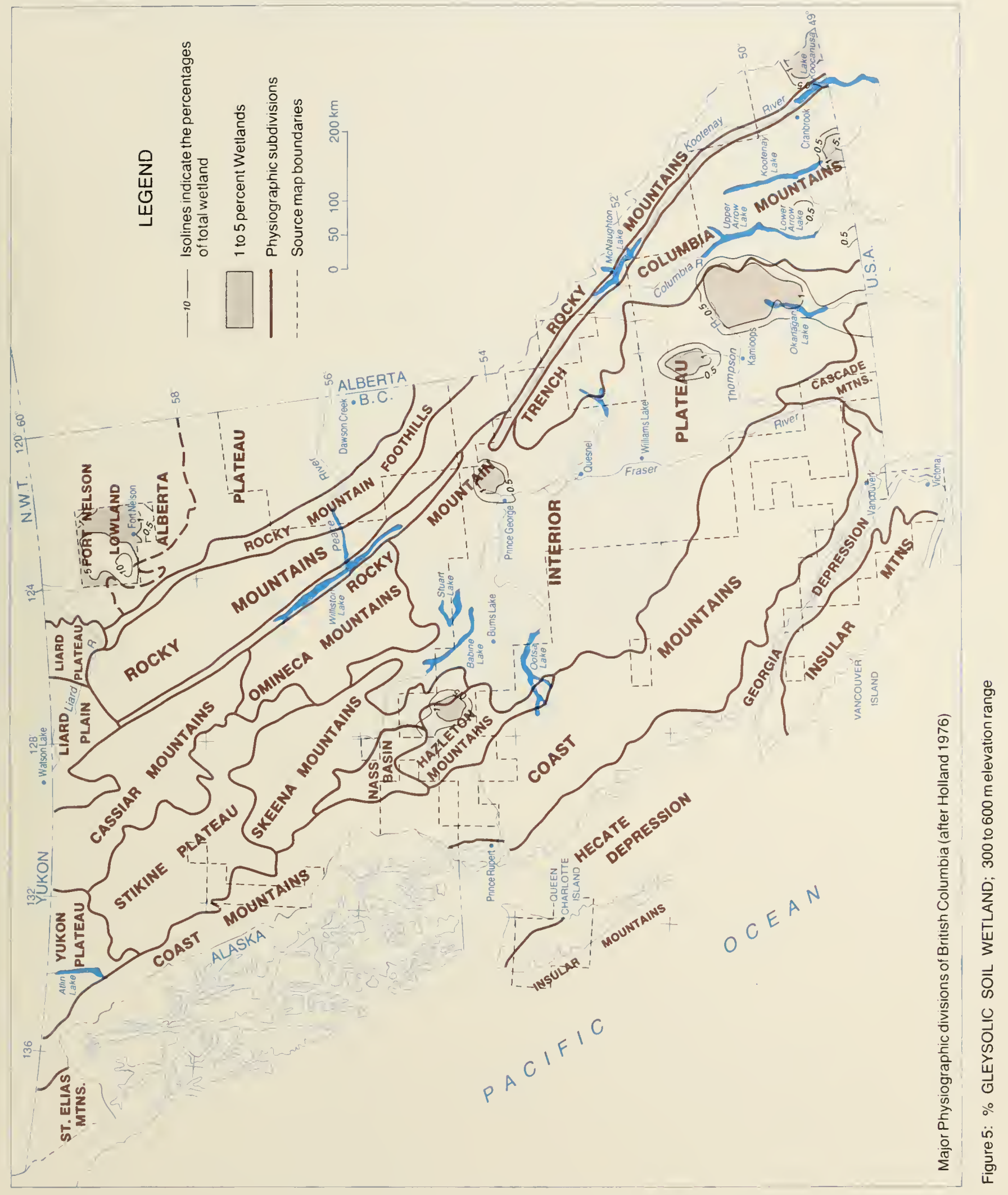





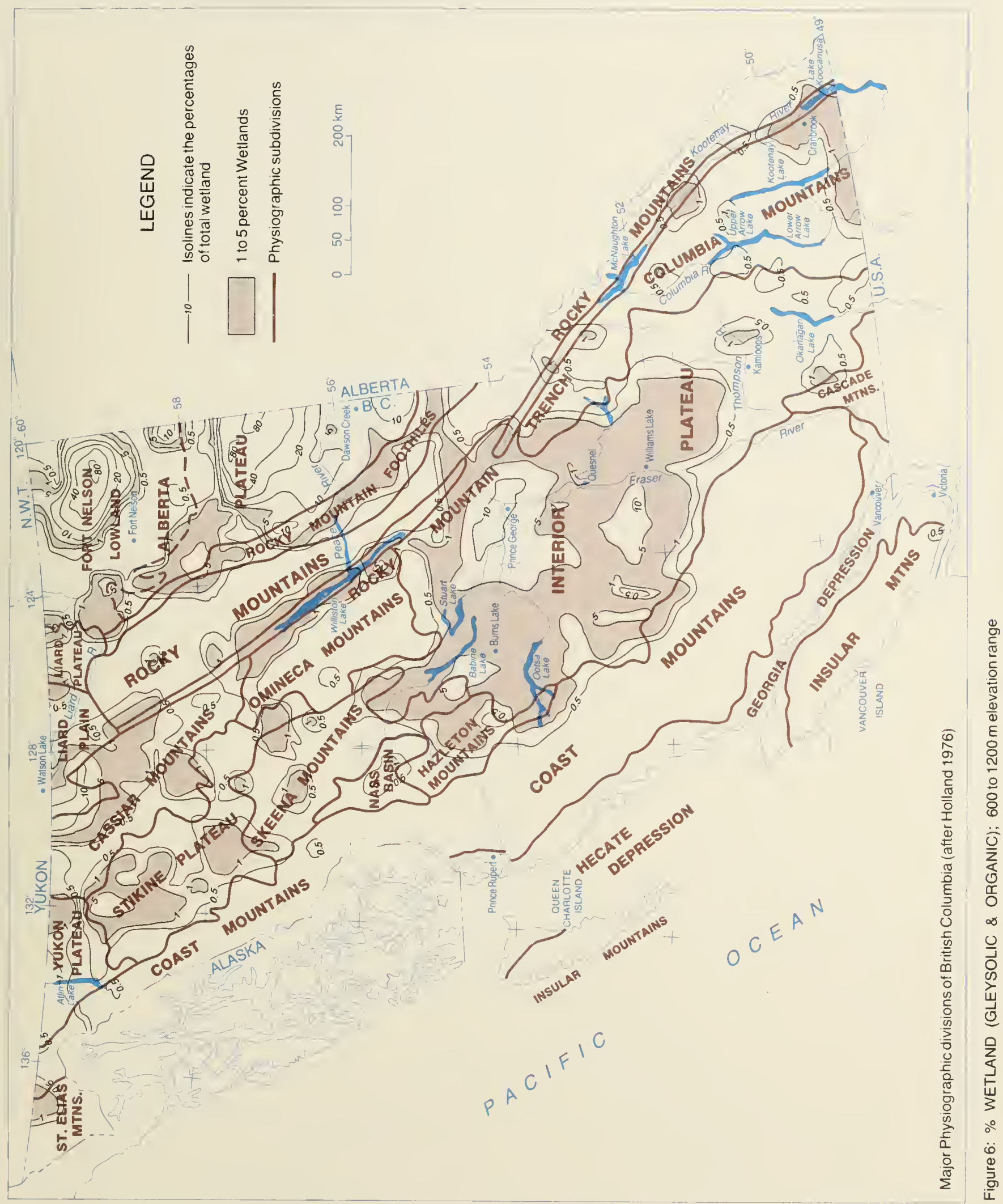





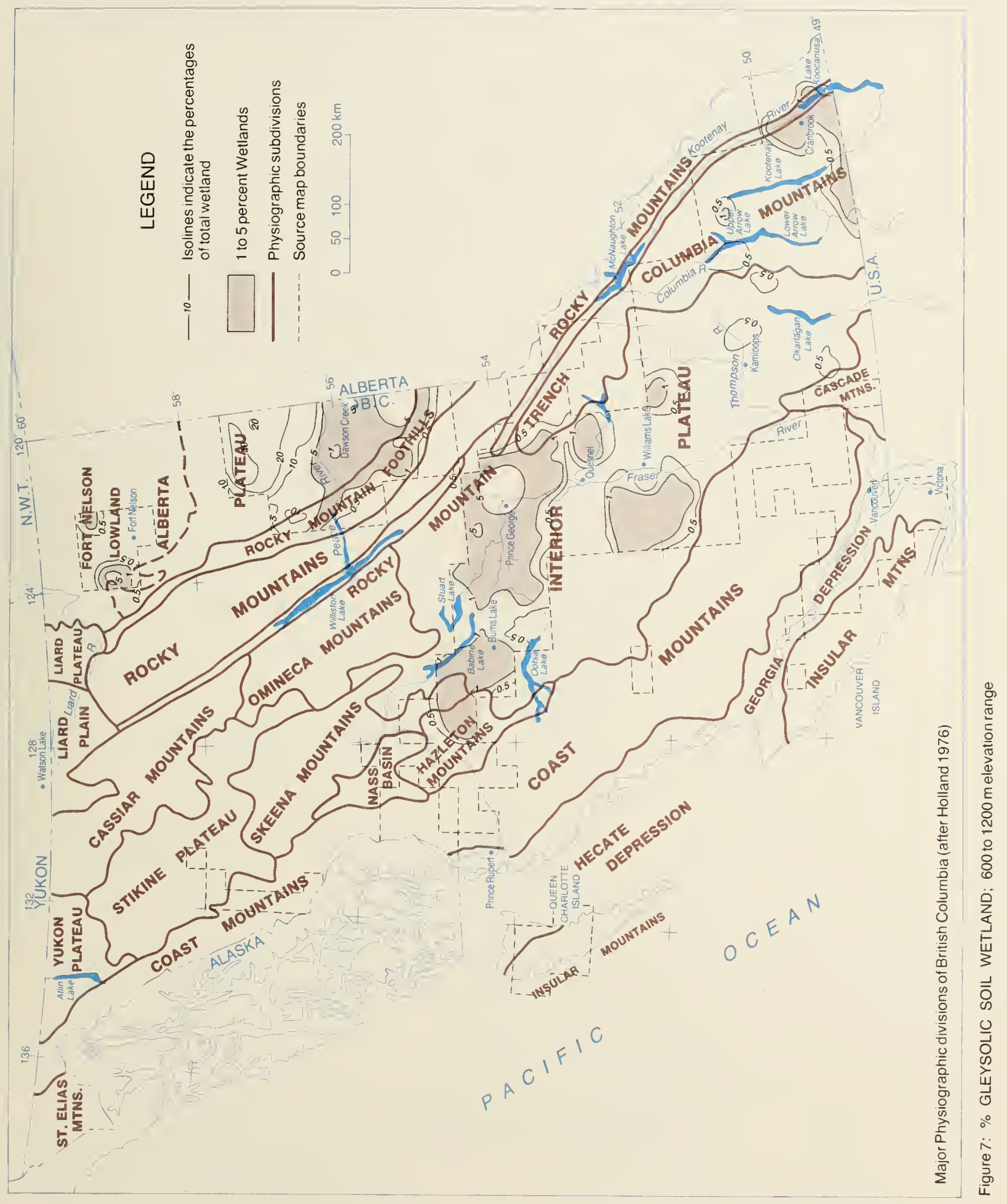



Table 1. British Columbia wetland areal distribution by physiographic subdivision groups.

\begin{tabular}{|c|c|c|c|c|c|}
\hline \multirow[b]{3}{*}{ Physiographic subdivision group ${ }^{3}$} & & & \multicolumn{3}{|c|}{ Total wetland area for: } \\
\hline & \multicolumn{2}{|c|}{$\begin{array}{l}\text { Total map } \\
\quad \text { area }\end{array}$} & \multicolumn{2}{|c|}{ Group ${ }^{1}$} & \multirow{2}{*}{ B.C. } \\
\hline & $\begin{array}{c}1000 \text { 's } \\
\mathrm{km}^{2}\end{array}$ & $\%$ & $\begin{array}{c}1000 ' \mathrm{~s} \\
\mathrm{~km}^{2}\end{array}$ & $\%$ & \\
\hline CORDILLERAN REGION & 845.8 & 89 & 15.5 & 2 & 29 \\
\hline Hecate Depression & 20.0 & 2 & $1.9^{4}$ & 9 & 4 \\
\hline Georgia Depression & 12.1 & 1 & 0.7 & 6 & 1 \\
\hline $\begin{array}{l}\text { Interior Plateau: } \\
\text { North (Nechako, Fraser, McGregor } \\
\text { Plateaux, Nechako Plain; Fraser } \\
\text { Basin; Quesnel Highland) }\end{array}$ & 151.7 & 16 & 6.1 & 4 & 12 \\
\hline $\begin{array}{l}\text { South (Thompson Plateau; Shuswap, } \\
\text { Okanagan Highlands) }\end{array}$ & 52.3 & 6 & 1.0 & 2 & 2 \\
\hline $\begin{array}{l}\text { Northwestern (Yukon, Stikine Plateaux; } \\
\text { Nass Basin) }\end{array}$ & 68.7 & 7 & 0.8 & 1 & 2 \\
\hline Liard Plain (including Dease Plateau) & 15.7 & 2 & 0.8 & 5 & 1 \\
\hline $\begin{array}{l}\text { Mountain (including Rocky Mountain } \\
\text { Foothills, Trench; Liard Plateau) }\end{array}$ & 525.3 & 55 & 4.2 & 1 & 8 \\
\hline $\begin{array}{l}\text { INTERIOR PLAINS REGION (ALBERTA } \\
\text { PLATEAU) }\end{array}$ & 102.8 & 11 & 37.4 & 36 & 71 \\
\hline Fort Nelson Lowland & 50.3 & 5 & 27.8 & 55 & 52 \\
\hline Peace River Lowland & 52.5 & 6 & 9.6 & 18 & 18 \\
\hline TOTAL FOR BC & 948.6 & 100 & $52.9^{4}$ & 5.6 & 100 \\
\hline
\end{tabular}

'Wetland density, based on total land area for each subdivision group.

${ }^{2}$ Wetland density, based on total wetland area $\left(52883 \mathrm{~km}^{2}\right)$ for BC.

${ }^{3}$ Adapted from Holland (1976) (Fig. 8).

${ }^{4}$ Adjusted using Dendron (1985) data. 


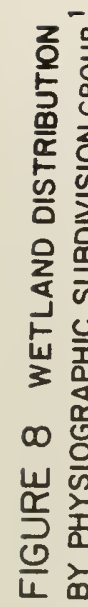
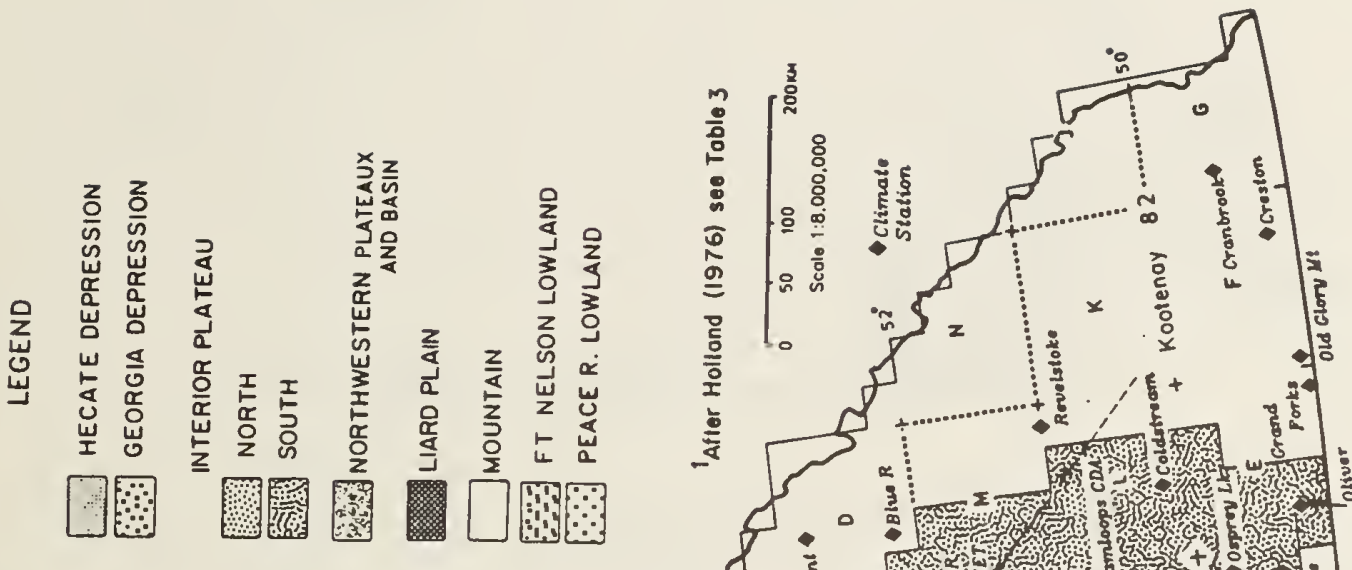

$\therefore \quad \mid$

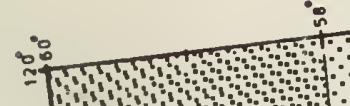

ह

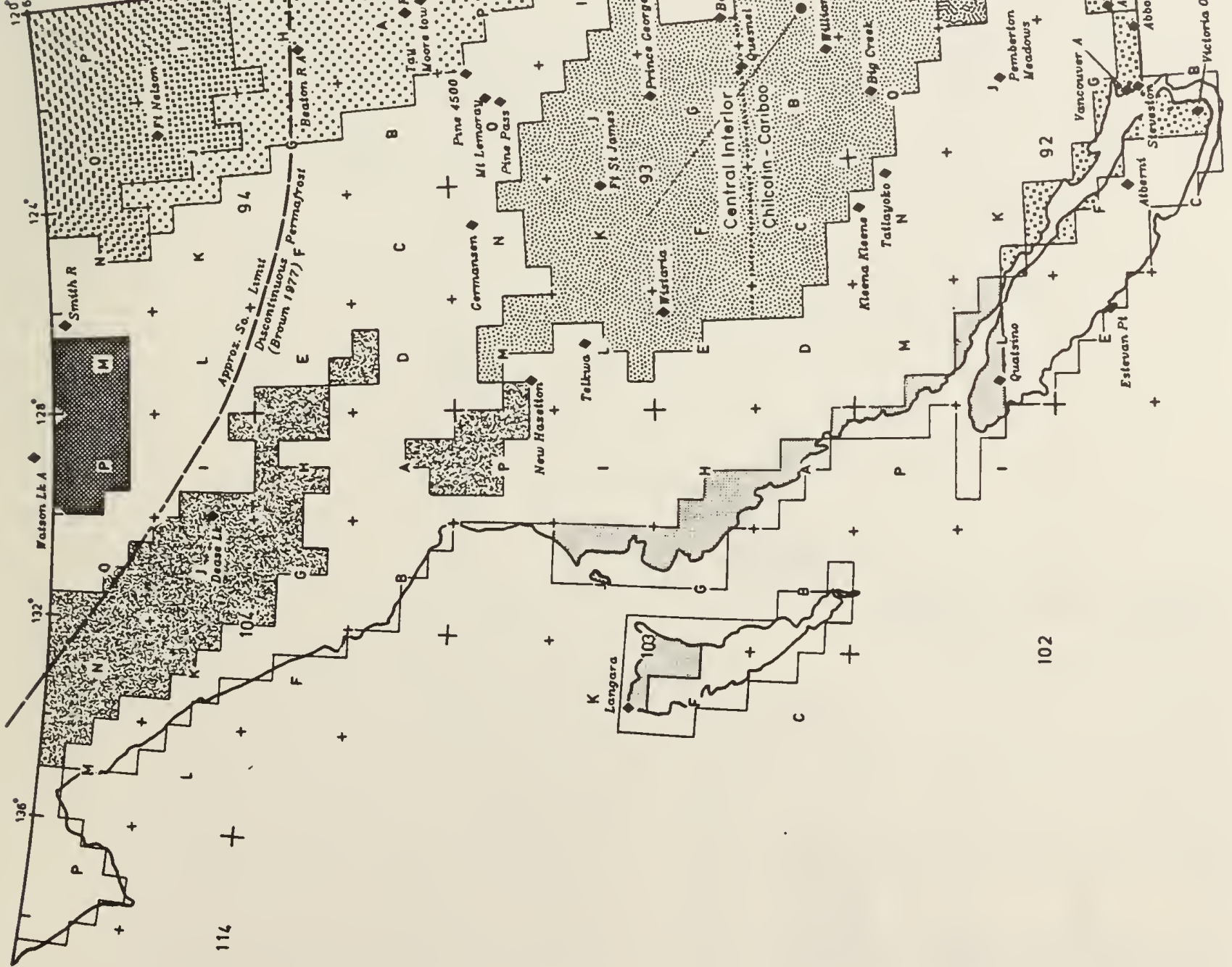


4. Methods 


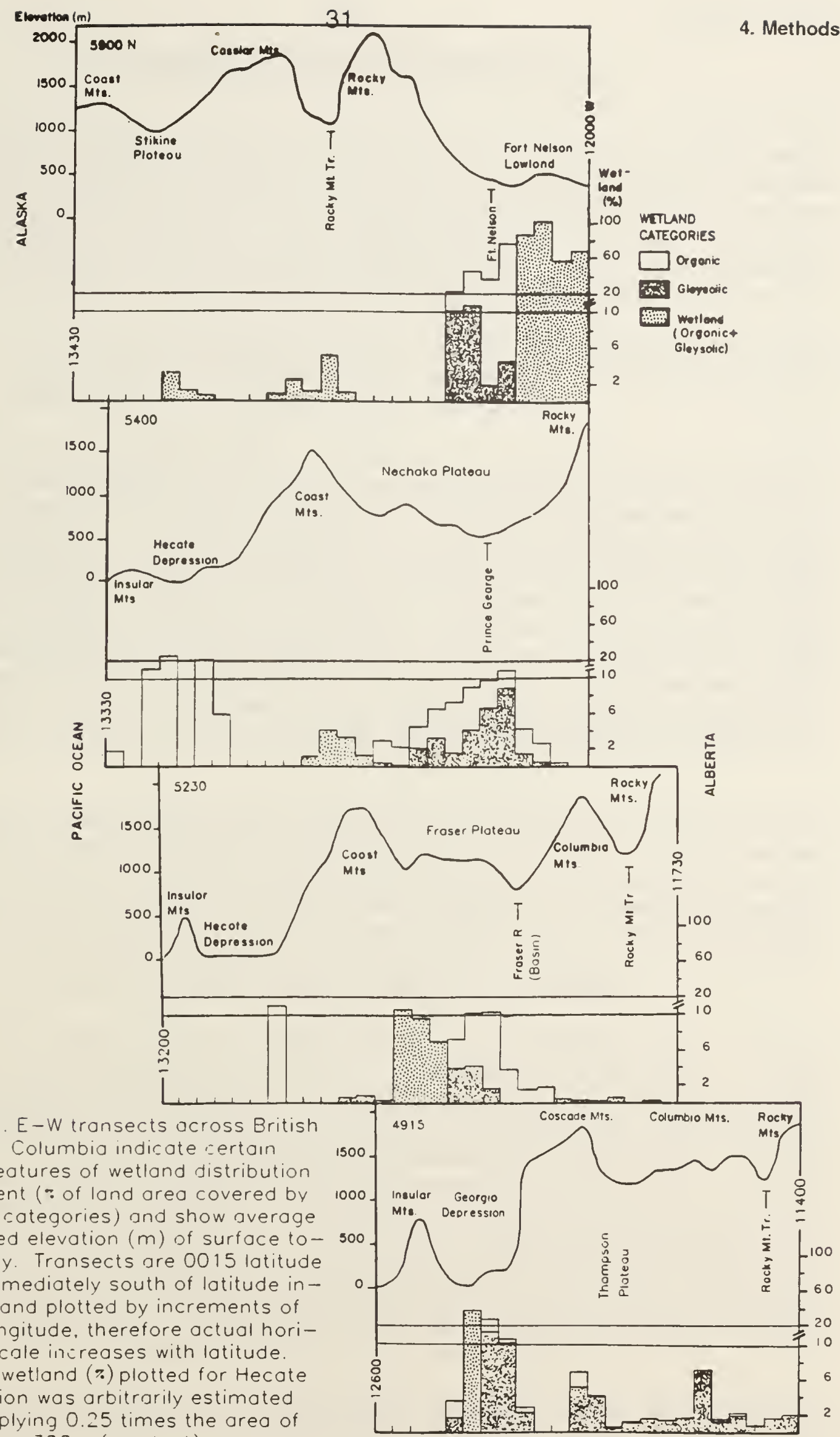


4. Methods 


\section{AGRICULTURAL USE OF WETLANDS}

Organic soils are desirable for crop production because they retain and supply water. Nutrients become available for new plant growth when the accumulated organic materials decompose. These soils offer little mechanical resistance for cultivation or root growth. The latter is especially important for root crops. The possible agricultural uses of wetland soils are determined by several other factors, including severity of climate, soil fertility level, ease of water management, susceptibility to subsidence and decomposition, and type of underlying materials.

Schaefer (1978) presented a concise summary of general characteristics of BC climate (Appendix 9.4). The best (lowest numerical rating) land capability class for agriculture is limited by its climatic capability for producing agricultural crops (BCME 1981).

Climatic capability for agriculture (CCA) classification, for an average calendar year, takes into account the following thermal and moisture parameters: freeze free period (FFP, consecutive days free of temperatures $0^{\circ} \mathrm{C}$ or less); growing degree days (GDD, accumulated daily mean temperature $5^{\circ} \mathrm{C}$ or greater, between the beginning of the first five and the end of the last five consecutive days with mean daily temperatures $5^{\circ} \mathrm{C}$ or greater); May through September climatic moisture deficit/surplus or balance (CMB, potential evapotranspiration subtracted from precipitation, where negative values indicate a deficit); and the ratio of climatic moisture surplus to potential evapotranspiration. The class ranges for each parameter are listed (Table 3). Class 1 is further subdivided for tree fruits (BCME 1981). This classification does not take into account stored soil moisture. Knowledge of at least monthly $\mathrm{CMB}$ and soil water holding characteristics of individual sites is required to calculate annual soil water storage, repletion and depletion at a particular site.

GDD for coastal areas, however, were over-rated compared to Interior BC areas because a significant portion of coastal GDD are accumulated over the longer coastal growing season near the threshold value $\left(5^{\circ} \mathrm{C}\right)$. This type of GDD contributes little to crop growth because the temperature-crop development relationship is not linear. A procedure was developed to calculate effective growng degree days (EGDD) for coastal climates (BCME 1981). GDD were considered under-rated for northern latitude areas because of long summer day-length (Cheesman and Davis 1982), however, this factor has not been taken into account for these areas.

The parameters listed above were defined and discussed, and CCA classes and their limitations were listed for representative long-term BC climatic stations (BCME 1981, see 1978a for CLI Soil Capability for Agriculture classifications and maps prepared before 1981). Limitations include aridity $(A)$, minimum temperatures near freezing $(F)$, insufficient heat units $(G)$, extreme minimum temperatures $(E)$ and excess growing season precipitation $(Y)$. Interim maps (1:100 000 scale) have been prepared by BCME depicting the parameters and climatic capability for certain of the agriculturally-important areas of BC. The CCA class rating system, best (1) to poorest (7), is defined in terms of these parameters and of the range of crops that can be grown for each class (BCME 1981). Wetland is often situated in basins and low-lying areas and is subject to cold air drainage and therefore more subject to frost than adjacent uplands - a further microclimatic limitation. Areas of Class 2 and 3 CCA generally occur adjacent to those of Class 1 , which are generally at the lowest elevations of the major valleys of southern $\mathrm{BC}$.

The Agriculture Land Reserve (ALR) included lands of Capability Class 1 to 4 and of other classes to include certain critical domestic livestock spring range to achieve areal continuity and 
a manageable system (Farley 1979). Some "fine tuning" of ALR boundaries has since occurred. The distribution of ALR lands and areas used for livestock grazing (Farley 1979) are shown (Appendix 9.5).

Table 2. Climatic capability for agriculture (CCA) classes for British Columbia'.

\begin{tabular}{|c|c|c|c|c|c|c|}
\hline & \multicolumn{2}{|c|}{$\mathrm{FFP}^{2}$} & \multirow{2}{*}{$\begin{array}{l}\mathrm{GDD}^{3} \\
{ }^{\circ} \mathrm{C} \text { day }\end{array}$} & \multirow{2}{*}{$\begin{array}{l}\mathrm{EGDD}^{4} \\
{ }^{\circ} \mathrm{C} \text { day }\end{array}$} & \multirow{2}{*}{$\begin{array}{l}\mathrm{CMB}^{5} \\
-\mathrm{mm}\end{array}$} & \multirow{2}{*}{$\begin{array}{c}\text { ratio }\end{array}$} \\
\hline & Interior day & Coastal day & & & & \\
\hline Class 1d & $>150$ & & 2225 & & & \\
\hline Class 1c & $>150$ & & $2060-2225$ & & & \\
\hline Class $1 \mathrm{~b}$ & $>150$ & & $1780-2059$ & & & \\
\hline Class 1a & $120-150$ & & $1505-1779$ & & & \\
\hline Class 1 & $90-119$ & $>150$ & $1310-1504$ & $>825$ & $>40$ & $>0.33$ \\
\hline Class 2 & $75-89$ & $120-150$ & $1170-1309$ & $736-825$ & $40-115$ & $0.34-0.55$ \\
\hline Class 3 & $60-74$ & $100-119$ & $1030-1169$ & $650-735$ & $116-190$ & $0.56-0.75$ \\
\hline Class 4 & $50-59$ & $80-99$ & $1030-1169$ & $491-649$ & $191-265$ & $0.76-1.00$ \\
\hline Class 5 & $30-40$ & $60-79$ & $780-1029$ & $421-490$ & $266-340$ & $<1.00$ \\
\hline Class 6 & $<30$ & $40-59$ & $670-779$ & $245-420$ & $341-415$ & \\
\hline Class 7 & $<30$ & $<40$ & $<670$ & $<245$ & $<415$ & \\
\hline
\end{tabular}

'Adapted from BC Ministry of Environment (1981).

${ }^{2} \mathrm{FFP}$ - Freeze-free period (base $0^{\circ} \mathrm{C}$ ).

${ }^{3} \mathrm{GDD}$ - Growing degree days $\left(5^{\circ} \mathrm{C}\right.$ or greater mean temperature).

${ }^{4} \mathrm{EGDD}$ - Effective growing degree days $\left(5^{\circ} \mathrm{C}\right.$ or greater mean temperature). Applies to Coastal area.

${ }^{5} \mathrm{CMB}$ - Climatic moisture balance, where negative indicates deficit.

${ }^{6} \mathrm{CMS} / \mathrm{PET}$ - Ratio, climatic moisture surplus to potential evapotranspiration.

Long term records from the Atmospheric Environment Service (Canada) where 'A' signifies Airport and

'CDA' Agriculture Canada, were used to determine the calculated climatic parameters quoted in tables of the text following.

Further, land capability limitations are related to soil characteristics. The application of these limitations, and those of climate, to land capability classification for agriculture in BC were given by Kenk and Cotic (1983). They discussed capability classes and sub-classes specifically for Organic soils based on 1) wood in the profile that might interfere with cultivation; 2) depth of organic deposit over bedrock; 3 ) degree of decomposition that may affect subsidence; and 4) the occurrence of continuous mineral soil layers in the profile that may affect crop growth and internal drainage.

Mathur and Levesque (1988) have suggested a revised agricultural rating scheme for Organics in Canada based on the Ontario system. They presented an expanded rating guide based on penalty points for undesirable features of seven factors: decomposition, wood content, reaction ( $\mathrm{pH}$ value), depth of organic deposit, underlying materials, climate and excess water. They thoroughly discussed how features of each factor relates to agricultural use.

Poor drainage (excess water) is the major limitation on the capability of wetland soils for growing agricultural crops. Poor drainage is mainly related to position in the landscape, low soil water permeability, and susceptibility to soil structure deterioration and organic material 
decomposition (Wood 1983, Driehuzen 1983, 1988). Water control structures will maintain water table levels and control flooding to accommodate the growth of specific climatically-adapted crops. Maintenance of a controlled water table is a distinct advantage for the many areas of BC that are subject to growing season drought (van Ryswyk 1983). Other agricultural limitations on wetland soils may include low nutrients, salinity, high acidity, coarse texture (enhanced drought) or fine texture (difficult drainage).

The distribution of agricultural land capability classes are summarized, from 1:50 000 scale CLI maps, by class groups in map (unimproved classes) and in tabular form (unimproved and improved classes) for each of the $\mathrm{BC}$ agriculture reporting regions and for each regional district (BCMAF 1976). Land capability classes 1, 2 and 3 are all capable of growing a wide range of crops; classes 4 and 5 are generally suitable only for forage crops with improvement potential; class 6 supports grazable native and/or introduced grasses and other forbs or shrubs; and class 7 has no potential for agricultural crops.

Wetlands in the unimproved (undrained, nonirrigated) state are usually rated class 4 to 6 but are rated one to two classes better (lower class number) in the improved state. In the lower Fraser Valley and southeast Vancouver Island, the improved state may result in a rating of class 1,2 or 3 , depending on climate. In the BC Interior, improved wetlands are usually rated only class 4 or 5 due to the harsher continental climate at higher elevations and only occasionally rate class 3 at the lowest elevations with the best climates. Only small areas of wetland soils occur in locations of class 1 or 2 climate in the BC Interior.

Fertility levels of wetland soils are highest in those that are most decomposed, increasing from Fibrisol, Mesisol to Humisol or Humic Gleysol. Lowe (1988) and Levesque et al. (1987) have given extensive discussions on chemical characterstics of Organic soils related to decomposition.

Water management is necessary on wetland soils to provide adequate aeration and to maintain a water table high enough to supply adequate water for the particular crop being grown. The size of each individual wetland area and the possibility of obtaining an adequate outlet to conduct excess water away, as well as the kinds of soil involved, determines the cost of developing water control structures. Fibrisol and Humisol are the most difficult Organic soils to drain because they have the lowest saturated hydraulic conductivity. Humic Gleysols, underlain by silty or clayey materials, are also difficult to drain. An extensive discussion on the hydrophysical characteristics of Organic soils has been given by de Vries (1988).

Fibrisols are the most susceptible to subsidence, particularly during the initial years following drainage and cultivation. This is due to the high potential for decomposition (high carbon to nitrogen ratio) which is reflected by their low bulk density. Continued cultivation for annual crops promotes aeration. Therefore, cultivation and fertilization, particularly with nitrogen, increase decomposition of all organic materials. The use of water-tolerant perennial forage species, however, allows for the least decomposition because of less aeration when the water table can be kept higher and only one or two cultivations may be needed to establish the perennial grass crop which will remain for several decades if properly managed.

When subsidence and decomposition reduce the thickness of the surface organic layers, underlying compact mineral layers cause root crops such as carrots, to become distorted, severely downgrading them for market. Mathur (1988) has shown that judicious application of 
copper can substantially reduce the decomposition of cultivated Organic soils growing horticultural crops in Ontario.

There is currently strong interest in global methane production because of its probable influence on global warming by a "greenhouse" effect. Levelton (1991) has presented and discussed methane prouction for BC. Total world methane production has doubled since preindustrial times, increasing at about $1 \%$ per year. Recently it has been estimated as 300000 kilotonnes per year (kt/yr) and Levelton (1991) estimated $686 \mathrm{kt} / \mathrm{yr}$ for BC for 1990. They separated this BC total into nine man-made sources, $532 \mathrm{kt} / \mathrm{yr}$, and four natural sources, 154 $\mathrm{kt} / \mathrm{yr}$. Of these 13 sources, landfill methane production was the largest, estimated at $290 \mathrm{kt} / \mathrm{yr}$, while the combined total.for domestic animals (eructation, respiration and flatulation) and manure was $95 \mathrm{kt} / \mathrm{yr}$. The largest natural source estimate was for wetlands, $130 \mathrm{kt} / \mathrm{hr}$, accounting for $19 \%$ of the BC total. Estimates project total BC methane production for the year 2005 to be about $5 \%$ over that for 1990 . Total methane production for BC accounts for only about $0.04 \%$ of the world total.

The following discussions were extracted from Talisman (1991) in regard to wetlands. Methane production is carried out by bacteria under strong anaerobic (oxygen deprived = reducing) conditions. It occurs from waterlogged (anaerobic) soils, aquatic-attached emergent plants, and organic matter under strong anaerobic conditions. Aerobic (well drained upland) soils are considered to act as methane absorbers, a small but significant sink in the global methane budget. Considerable uncertainly still exists, however, on the estimate of methane production, particularly for northern North American wetlands because of scarcity of field research.

When wetlands are drained for urban, commercial and/or agriculture development, methane production is expected to decrease. Alternately, hydroelectric projects which flood carbon stores, such as peat, forest floors or vegetation, will increase methane production. Similarly, flooding of wetlands by beaver activity, which has increased since 1950, will increase methane production over that of unflooded wetlands in the order of decreasing magnitude: beaver pond $>$ marsh $>$ rich fen > poor fen > bog.

Beaver ponds and other shallow water bodies contribute to methane production by creating 1) anaerobic conditions; 2) large surface areas for efficient absorption of solar energy; 3 ) great thermal inertia (water acts as a heat sink) to maintain high temperatures; 4) habitat for aquatic plants which transfer methane directly from sediments, circumventing oxidation of methane in the water column; and 5) accumulation of great quantities of carbon. 


\section{AGRICULTURAL USE AND EXTENT OF WETLANDS BY PHYSIOGRAPHIC SUBDIVISION GROUPS}

\subsection{Introduction}

The total area of wetland estimated from all map sources for all eievation categories is $52883 \mathrm{~km}^{2}$ (Table 1), or $5.6 \%$ of the total land area (948 $600 \mathrm{~km}^{2}$, Farley 1977) of BC. Soil-CLI mapped areas cover $382730 \mathrm{~km}^{2}$, or $40 \%$ of the total area of BC and account for $24110 \mathrm{~km}^{2}$ $(46 \%)$ of wetland. Gleysolic soils cover $10068 \mathrm{~km}^{2}(42 \%)$ of these soil-CLI wetlands.

The Cordilleran Physiographic Region occupies $89 \%$ of total BC land area, and contains $2 \%$ wetland, representing $29 \%$ of total BC wetland (Table 1). The remainder $(11 \%)$, is occupied by the Interior Plains Region in northeastern BC, and contains $36 \%$ wetland, representing $71 \%$ of BC wetland. Total BC wetland is distributed, in descending order, among the 9 physiographic subdivision groups: Fort Nelson Lowland 52\%, Peace River Lowland 18\%, north Interior Plateau $12 \%$, Mountains $8 \%$, Hecate Depression $4 \%$, south Interior Plateau $2 \%$, Northwestern $2 \%$, Georgia Depression 1\%, and Liard Plain 1\% (Table 1, Fig. 8). However, the groups can be arranged from the original group in decreasing order of wetland density: Fort Nelson Lowland $(55 \%)$, Peace River Lowland (18\%), Hecate $(9 \%)$ and Georgia $(6 \%)$ Depressions, Liard Plain $(5 \%)$, north Interior Plateau (4\%), south Interior Plateau (2\%), Northwestern (1\%) and Mountain $(1 \%)$.

Six percent of the total wetland area occurs below 300 m elevation (Table 2), almost all in the coastal Depressions (compare Fig. 2 to Fig. 4). The largest area, $46 \%$, occurs in the 300 to $600 \mathrm{~m}$ category, $96 \%$ of that in the Fort Nelson Lowlands of northeastern BC (Fig. 2 and 4). The 600 to $900 \mathrm{~m}$ category includes the second largest area of wetland (34\%), $49 \%$ of which occurs in the Peace River Lowlands of northeastern BC (Fig. 2 and 6). Above $900 \mathrm{~m}$, wetland area decreases consistently with each $300 \mathrm{~m}$ increase in elevation to the $>1500 \mathrm{~m}$ category, inclusive. The 300 to 1200 m elevation range includes $89 \%$ of the total area of BC wetlands.

The proportion of Organics to Gleysols varies with elevation category (Table 2) and with physiographic subdivision for the Soil-CLI surveyed areas. Organic soils dominate in the 0 to 300 and 300 to $600 \mathrm{~m}$ categories, particularly in the Fort Nelson Lowland (Fig. 2,4,5) and in the 600 to $1200 \mathrm{~m}$ category in the north Interior Plateau (Fig. 6,7,9). Gleysolic soils dominate in the 0 to $300 \mathrm{~m}$ category for the Georgia Depression (Fig. 2,3,9) and in all elevation categories for the soilCLI surveyed Mountain group (Kootenay) of southeastern BC (Fig. 6,7,9).

The amount of wetland, however, is less important than the quality of climate and soil characteristics for production of agricultural crops. Extent and agricultural use of wetlands are presented in this report by physiographic subdivision groups and, where possible, in relation to the areal and elevational extents, WR, climate and CCA rating, and soil classification and characteristics. In addition to grazing and browsing by domestic animal species, wetlands are also used for rećreational purposes, for sustenance by local or aboriginal peoples and by wildlife, production of tree and horticultural crops as well as regulation of water regimes. However, these other uses are given as understood and are not discussed at any length in the context of this bulletin. Supplementary wetland soil information is given (Section 7.1 to 7.9 ) for certain aspects of the groups. 
Soil survey reports and maps and the specific areas each cover are indicated by NTS designation under Literature Cited (Chapter 6). Soil maps which are not included with a particular report are so indicated. Where the areas of wetland soil map units are given, those areas $\left(\mathrm{km}^{2}\right)$ and the percent of wetland based on total surveyed area, which may or may not include water bodies and other miscellaneous areas depending on the report, are indicated in tabular form or text. Soil map scales are 1:100 000 unless otherwise noted. Many BCMAFF and BCME reports, maps and related publications are available from Maps BC, Ministry of Crown Lands, Parliament Buildings, Victoria, B.C. V8V 1 X4.

Table 3. Elevational distribution' of British Columbia wetland area in $\mathrm{km}^{2}$ and $\%$ of total $\mathrm{km}^{2}$.

\begin{tabular}{lcccccccc}
\hline \hline & \multicolumn{7}{c}{ Elevation category $(\mathrm{m})$} \\
\cline { 2 - 8 } Wetland & $0-300$ & $300-600$ & $600-900$ & $900-1200$ & $1200-1500$ & $>1500$ & Total \\
\hline \multirow{2}{*}{ Total } & 3375 & 24427 & 17677 & 4861 & 1667 & 873 & $52883^{2}$ \\
& 6 & 46 & 34 & 9 & 3 & 2 & 100 \\
Organic $^{3}$ & 2171 & 3846 & 5384 & 1760 & 493 & 389 & $14042^{2}$ \\
& 16 & 27 & 38 & 13 & 3 & 3 & 100 \\
Gleysolic $^{3}$ & 884 & 1098 & 6098 & 1184 & 391 & 413 & 10068 \\
& 9 & 11 & 60 & 12 & 4 & 4 & 100 \\
\hline
\end{tabular}

${ }^{1}$ Based on total wetland area for each wetland category.

${ }^{2}$ Adjusted using Dendron (1985) data for ârea of peatlands for relevant portions of NTS map sheets $92 \mathrm{~L}, \mathrm{M}$; 102 I (estimated); 102 P; 103 A,F, G,H,J,K (1912 km² instead of $\left.8098 \mathrm{~km}^{2}\right)$.

${ }^{3}$ Based on a total land area of $382730 \mathrm{~km}^{2}$ (Soil-CLI surveyed area).

A series of interim soil survey reports and proceedings were prepared by the BCMAFF, Soils Branch, Kelowna in the 1950's and 60's under the auspices of a Reclamation Committee. The proceedings outlined in detail irrigation water requirements by soil map unit for several agriculturally developed soils and soils which would have the potential for development in portions of the drainage basins of the Kootenay-Columbia, Fraser, Okanagan and Thompson Valleys. A few of these reports, but none of the proceedings, are referred to in this bulletin. However, some of the reports and proceedings may be available from the relevant BCMAFF offices.

Many authors have discussed further details of settlement history, natural resources, physiography and drainage patterns, bedrock and surficial geology, vegetation, associated welldrained soils, climate and climatic capability ratings for agriculture as well as for other uses, for the respective map areas.

Only research studies relating to fertility and crop production on wetland soils are referred to in the scope of this bulletin. Relevant nutrient extraction, incubations and greenhouse/growthroom techniques for evaluating soil fertility or physical status are noted but not discussed. 


\subsection{Hecate Depression}

Extent Wetlands assigned to the Hecate subdivision group cover $1868 \mathrm{~km}^{2}$ (Dendron 1985), or $9 \%$ of the area of that group, and account for about $4 \%$ of total BC wetland area (Table 1). Most of the Hecate wetlands occur below $300 \mathrm{~m}$ elevation. These were assigned to the undifferentiated Gleysolic/Organic category but designated Coastal Slope bog (Fig. 2).

Wetland Region The Hecate group roughly coincides with the North Coast Pacific Oceanic WR but includes northern portions of the South Coast Pacific Oceanic and Pacific Temperate WR (NWWG 1986). Wetlands of the North Coast are characterized by flat and slope bog wetland forms that cover $83 \%$ of the wetland area and have an average depth of organic material of 1.6 and $1.9 \mathrm{~m}$ (coefficients of variation, 54 and $61 \%$ ), respectively along with basin bogs (Dendron 1985). Stream fens $(<2 \mathrm{~m})$, basin swamps, and along the coast, coastal and estuarine marshes are common, and cover most of the remainder of the area. Some individual bog wetlands occupy areas greater than 5000 ha. Fen-bog complexes and undifferentiated wetlands were identified in the South Coastal and Pacific Temperate WR (Dendron 1985).

Wetlands of the lowland portion of northeastern Queen Charlotte Islands are dominantly flat bogs whereas those of the Insular Mountain portion are dominantly slope bogs. The west coast of the Queen Charlotte Islands (Graham and Moresby) and the Brooks Peninsula (94 L/4) on Vancouver Island (not shown on Fig. 8) have extensive areas of "coastal slope bog" (J. Pojar, personal communication). Pojar also notes that a very sharp break occurs between the high density "coastal slope bog" and adjacent steeply sloping areas, closely following the $300 \mathrm{~m}$ elevation contour. However, severity of the slope is not necessarily a limiting factor. Slope bogs cover the western slopes of the Insular Mountains due to direct exposure to Pacific storms but do not cover corresponding slopes of the Coast Mountains to the same extent.

Bogs are composed of poorly humified (undecomposed) sphagnum moss peats overlying well humified amorphous peats and are characterized as extremely acid and low in nutrients. They support woody shrub, sphagnum moss and tree species in tall or shrub forms that can thrive without the influence of nutrient-rich ground waters. A medium to light cover of tree species include yellow cedar (Chamaecyparis nootkatensis), shore pine (Pinus contorta var. contorta), western red cedar (Thuja plicata) and western hemlock (Tsuga heterophylla). Several shrub indicator species and the most common moss (Sphagnum spp.) occur indicating the bog environment (Dendron 1985).

In contrast, the fen peatlands consist of less acidic, moderately humified sedge and amorphous peat that is higher in calcium and has developed under the influence of nutrient-rich waters. The plant communities are characterized by sedges (Carex spp.), very sparse shore pine and the indicator specie, sweet gale (Myrica gale) (Dendron 1985).

The development of these wetlands since deglaciation, the vegetation and peat characteristics, the value of their organic deposits for fuel and horticultural uses have been addressed by Dendron (1985). Their vegetation has been further discussed by Selby (1983). Banner et al. (1986) presented characteristics of representative wetland types of the north Pacific Oceanic wetlands and discussed the successional development of forest and peatland vegetation in relation to the processes of bog and fen peat formation since deglaciation. Indeed, they suggest that the development of these wetlands is as much due to the cool, humid, wet oceanic climate as it is to edaphic (soil) and/or topographic characteristics. Wetlands of Pacific Canada have been thoroughly discussed by Banner et al. (1988) and the estuarine and coastal salt 
marshes that occur in both the Hecate and Georgia Depression have been discussed by Glooschenko et al. (1988).

Climate The Hecate group receives the highest precipitation of any part of $B C$ because it is situated on the windward (west) side of the Coast and Insular Mountains, receiving the full force of the Pacific Ocean storms. The high precipitation together with poor accessibility (Maynard 1988) make it extremely difficult to drain wetlands for agricultural and/or peat extraction purposes and to dry peat for the latter. Although storms abate during the growing season, cloudy weather persists, resulting in cool conditions. The cool, wet, cloudy climate of the north and south Coast Pacific Oceanic wetlands are characterized by a range of 13 to $16^{\circ} \mathrm{C}$ for mean daily July temperatures, $2420 \mathrm{~mm}$ mean annual total precipitation and 900 hours of average bright sunshine for May through September averaged for all stations (Dendron 1985). Values for the cool wet climate of the north Pacific Oceanic WR are 6.7 to $8.5^{\circ} \mathrm{C}$ mean annual temperature with no month below $0^{\circ} \mathrm{C}$ nor above $10^{\circ} \mathrm{C}$ from May through September and 1150 to $4400 \mathrm{~mm}$ mean annual total precipitation gives a continuous high relative humidity (Banner et al. 1986). Positive CMB values were calculated (BCME 1981) for Langara (+289 mm) in the north and for Quatsino (+65 $\mathrm{mm}$ ) in the south (Table 4, Fig. 8). The improved (drained) CCA for these respective stations were 4 and 2 with limitations due to insufficient heat units (EGDD) when the excess water limitation was removed. For these reasons the climate is generally unsuitable for growth of most commercial agricultural crops.

Table 4. Elevation, climatic parameters and climatic capability for agriculture of selected stations ${ }^{1}$ for Hecate, Depression and Mountain (Insular) and for Georgia Depression groups.

\begin{tabular}{|c|c|c|c|c|c|c|}
\hline \multirow[b]{2}{*}{ Station } & \multirow[b]{2}{*}{$\begin{array}{c}\text { Elevation } \\
\mathrm{m}\end{array}$} & \multirow{2}{*}{$\begin{array}{c}\text { Effective } \\
\text { growing } \\
\text { degree days } \\
\left(>5^{\circ} \mathrm{C}\right) \\
{ }^{\circ} \mathrm{C} \text { day }\end{array}$} & \multirow{2}{*}{$\begin{array}{c}\text { Freeze free } \\
\text { period } \\
\left(<0^{\circ} \mathrm{C}\right) \\
\text { day }\end{array}$} & \multirow{2}{*}{$\begin{array}{c}\text { Climatic } \\
\text { moisture } \\
\text { balance } \\
\mathrm{mm}\end{array}$} & \multicolumn{2}{|c|}{$\begin{array}{l}\text { Climatic capability } \\
\text { for agriculture }\end{array}$} \\
\hline & & & & & $\begin{array}{l}\text { Improved } \\
\text { class }^{2}\end{array}$ & $\begin{array}{c}\text { Unimproved } \\
\text { class }^{2}\end{array}$ \\
\hline & \multicolumn{6}{|c|}{ Hecate Depression and Mountain (Insular) } \\
\hline Estevan Pt. & 7 & 734 & 225 & +309 & $3 G$ & $4 Y$ \\
\hline Quatsino & 8 & 783 & 212 & +65 & $2 G$ & $2 G$ \\
\hline \multirow[t]{2}{*}{ Langara } & 41 & 536 & 236 & +289 & $4 G$ & $5 Y$ \\
\hline & \multicolumn{6}{|c|}{ Georgia Depression } \\
\hline Agassiz $\mathrm{CDA}^{3}$ & 15 & $2052^{4}$ & 210 & +29 & 1 & 1 \\
\hline Abbotsford A. & 58 & 976 & 169 & -98 & 1 & $2 A$ \\
\hline Steveston & 1 & 928 & 172 & -177 & 1 & $3 A$ \\
\hline Duncan & 6 & 1158 & 164 & -304 & 1 & $5 A$ \\
\hline
\end{tabular}

${ }^{1}$ From BCME (1981) Station locations indicated on Fig. 8.

${ }^{2}$ Class limitation indicated by: A-aridity (negative climatic moisture balance), G-insufficient heat units (growing degree days), $Y$-excess precipitation, May to September.

${ }^{3} \mathrm{CDA}$ - Agriculture Canada station (Luttmerding 1981a), climatic capability for agriculture estimated.

${ }^{4}$ Growing degree days. 
Wetland soil Mesisols and Humisols are typically associated with the bog and fen wetland classes of the north Pacific Oceanic WR but Gleysolic soils also occur, all associated with Folisols. Bogs cover virtually all ranges of topographic classes but fens are most common along drainage systems of the Queen Charlotte lowlands (Banner et al. 1986).

The surficial layers of sphagnum peat of these wetland soils may be suitable for horticultural peat but are relatively thin. The underlying well-humified sedge peat would be a potential source for fuel peat. However, problems related to drainage, drying and accessibility would limit development of peat extraction for either use (Maynard 1988).

\subsection{Georgia Depression}

Extent Georgia group wetlands cover $721 \mathrm{~km}^{2}$ and occupy $6 \%$ of the total area of this group accounting for $1 \%$ of BC wetland area (Table 1). These wetlands occur mainly below $300 \mathrm{~m}$ and are dominated $(70 \%)$ by Gleysols (Table 5$)$. The concentration of wetlands varies from less than $1 \%$ near Hope to more than $20 \%$ near the Strait of Georgia (Fig. 2).

Table 5. Elevational distribution of wetland area in $\mathrm{km}^{2}$ and $\%$ of total map area for the Georgia Depression group ${ }^{1}$.

\begin{tabular}{lrrrr}
\hline & & \multicolumn{3}{c}{ Elevation category $(\mathrm{m})$} \\
\cline { 3 - 5 } $\begin{array}{c}\text { Wetland } \\
\text { category }\end{array}$ & $\begin{array}{c}\text { Total map } \\
\text { area }\end{array}$ & $0-300$ & $300-600$ & Total \\
\cline { 3 - 4 } Total & 12095 & 720 & 1 & 721 \\
& 100 & 6.0 & $<0.1$ & 6.0 \\
Organic & 11752 & 174 & 1 & 175 \\
& 100 & 1.5 & $<0.1$ & 1.5 \\
Gleysolic & 11752 & 417 & $<1$ & 417 \\
& 100 & 3.5 & $<0.1$ & 3.5 \\
\hline
\end{tabular}

'See Fig. 8. Organic and Gleysol wetland areas derived from Soil-CLI surveyed map sheets (Fig. 1).

Wetland Region These wetlands lie in the Pacific Temperate WR that is characterized by horizontal fens (peat $<4 \mathrm{~m}$ thick), basin swamps ( 4 to $5 \mathrm{~m}$ ), flat and basin bogs $(2 \mathrm{~m}$ ), with local coastal marshes, especially on deltaic areas and other marshes on flood plains (NWWG 1986).

Climate The Pacific Temperate WR climate is humid with mild winters, warm summers and high annual precipitation (NWWG 1986). However, in contrast to the north Coast Pacific Oceanic WR climate, it has higher daily July temperature $\left(18-19^{\circ} \mathrm{C}\right)$, less total annual precipitation (1250 $\mathrm{mm}$ ) and more hours (1100) of bright sunshine, all averaged for selected stations (Dendron 1985).

The Langley-Vancouver map area is generally characterized by warm, rainy winters and relatively cool dry summers (Luttmerding 1981a, Vol. 3, portion $92 \mathrm{G} / \mathrm{S}$ ). Indeed, much of this area suffers from negative CMB (range from $+29 \mathrm{~mm}$ at Agassiz to $-177 \mathrm{~mm}$ at Steveston) (Table 
4, Fig. 8), indicating that growing season drought can occur over much of the lower Fraser Valley depending on water holding capacities of the individual soils.

Calculated EGDD for certain coastal stations include 928 for Steveston, near Vancouver, and 1158 for Duncan on Vancouver Island (Table 4). Average total hours of bright sunshine for Vancouver International Airport are 1925, 1420 of which occur during May to September inclusive.

Luttmerding (1981a, Vol. 3) gives further detailed climate data for several stations. Day et al. (1959; portions of 92 B/W, C9, F/SE and NW; 1:63 360) give an extensive discussion of three fairly well defined types of the Inner Coast climate for southeastern Vancouver Island, including aspects of soil moisture deficiency, ranging from $305 \mathrm{~mm}$ for the Dominion Observatory near Victoria to $145 \mathrm{~mm}$ for Alberni. Average CMB is $-177 \mathrm{~mm}$ for Steveston and $-304 \mathrm{~mm}$ for Duncan, both with Class 1 improved (irrigated) CCA.

Climate of most of the Georgia Depression has been rated among the best in $\mathrm{BC}$ for production of a wide range of horticulture, forage and other field crops (BCME 1981). Thus, the major land use has been agriculture on suitable soils. The agricultural area of the lower Fraser Valley accounted for $51 \%$ of the 1980 total farm gate value ( $\$ 750$ million) of BC agricultural production (Luttmerding 1981a, Vol. 3). Of 41 agriculture soil management groups discussed by Luttmerding (1984, Vol. 5), 21 involve wetland soils, indicating the importance of these soils for agriculture.

Wetland Soil Soils of the Langley-Vancouver map area (Luttmerding 1981a, $92 \mathrm{G} / \mathrm{S}$ ) include a wide range of Orthic and Peaty Gleysols and Humic Gleysols; and Organic Humisols, Mesisols and Fibrisols. The Gleysols occur mainly on silty and clayey fluvial, glaciomarine or marine, or lacustrine deposits and Organics occur on organic deposits 40 to greater than $160 \mathrm{~cm}$ deep. About $10 \%$ of these wetlands have well decomposed surface layers.

Luttmerding (1984, Vol. 5) presented a thorough discussion of the characteristics of each wetland soil management group and management considerations for best crop production. Control of the water table with adequate drainage structures was the prime consideration. Water control was not only necessary for best crop growth but also to ensure good trafficability during planting and harvesting operations in the spring and fall. Bertrand et al. (1991) prepared a producers' interpretive handbook, based on data and experience of Luttmerding (1984) and several other soil specialists, which outlined management techniques for successful crop production for 39 soil management groups. Ten of these soil groups included wetland soils. Special attention was given to the soil structure problems of compaction and puddling, especially important for the clayey Gleysolic soils but also for certain Organics, and to drainage and irrigation for all of the wetland soils.

The availability of potential irrigation water can be beneficial for crops on wetland soils because of the negative $\mathrm{CMB}$ that can occur. In some instances, on certain soils, subirrigation can be effected by using modified drainage structures.

Safo and Lowe (1973) reported on the manganese status of six Fraser Lowland (portion of Georgia Depression roughly equivalent to Lower Fraser Valley, Holland 1976) soils including Orthic Humic and Humic Eluviated Gleysols (now Humic Luvic Gleysol, ACECSS 1987) for total manganese and for three available manganese methods. Parasher and Lowe (1970) studied three dispersion methods to isolate clay-sized organo-mineral complexes from seven Fraser Lowland soils including Orthic, Orthic Humic and humic Eluviated Gleysols. Kowalenko and Lowe 
(1975a) evaluated several incubation methods for estimating soil sulfur mineralization and its relationship to soil carbon, nitrogen and phosphorus (Kowalenko and Lowe 1975b) of four Fraser Lowland soils, one a Gleysol. Lowe and Hinds (1983) utilized an aerobic incubation procedure to evaluate the susceptibility to mineralization of nitrogen and sulfur of five Fraser Lowland Gleysolic soils and for four respective mineral particle-size fractions. Lowe et al. (1971) found that the ratio of sulfur 34:sulfur 32 of the humic acid fraction of a Humisol did not change from that of the standard but the ratio for a Humic Eluviated Gleysol increased. This type of analysis may be useful to study soil sulfur transformation.

Gu and Lowe (1990) studied the adsorption of boron (as boric acid) on three precipitated humic acids derived from each of three surface soils including a Humic Luvic Gleysol (Fraser Lowland, Langley Soil Series) and concluded that "the role of humic acid is expected to be minor in most acid and near neutral soils, but may be of greater significance in soils of high $\mathrm{pH}$ and above average organic matter content."

Lowe and Bustin (1985) reviewed several studies on the forms of sulfur in the Fraser Lowland (Delta municipality) peats indicating that "sulfur contents of peat can be highly variable and related to vegetation inputs, which in turn are influenced by the $\mathrm{pH}$ and presence or absence of salt water in the depositional environment." They concluded that "the large proportions of sulfur and carbon resistant to hydrolysis indicated a rather high degree of chemical (and perhaps biological) stability."

Olson and Lowe (1990a,b) subsequently studied the effects of long-term intensive vegetable production on some chemical properties and nutrient (carbon, nitrogen, sulfur) mineralization of a Humisol in the Fraser Lowlands (Serpentine and Nicomekel River floodplains near Cloverdale) and on hydrolyzeable portions of these nutrients (Olson and Lowe 1990b). Paired soil profile samples were collected from two transects, one in a 40-year old vegetable field, the other in an adjacent fence row, each positioned to collect respective samples from each of a relatively deep organic deposit, and from a shallow deposit where a ridge of mineral soil had been exposed by cultivation.

Initial analysis showed that cultivation had changed some chemical properties only in the plow layer (Olsen and Lowe 1990a). The exception was $\mathrm{pH}$, which was highest throughout the sampled depth of each deposit of the cultivated transect. Organic matter loss from the cultivated transect was estimated at $28 \%$ by weight, based on ash accumulation. In the cultivated deep organic deposit (west of ridge), organic matter and carbon content were reduced by 7.1 and $5.6 \%$, respectively, whereas on the cultivated ridge the following content reductions applied: organic matter (43\%), carbon (42\%), nitrogen (43\%) and sulfur (26\%); and mineralized amounts: carbon $(43 \%)$, nitrogen $(61 \%)$ and sulfur $(53 \%)$. On an ash-free basis, there were no changes in the deep organic deposit but on the ridge, the organic matter sulfur content had increased and the amount of nitrogen and sulfur mineralized weredecreased compared with the uncultivated transect. In the cultivated surface layer, increased sulfur content in the organic matter was caused by incorporation of a sulfur-rich subsurface layer during tillage operations. Increases in phosphorus content in the cultivated transect were attributed to phosphorus fertilization. Within the cultivated transect, carbon, nitrogen and sulfur content in the exposed ridge were 48, 48 and $44 \%$, respectively, lower than in the deep organic surface layer. The carbon-nitrogen ratio remained at about 16 . The chemical stability of organic matter was attributed to its welldecomposed nature, its degradation due to excess cultivation being manifested mainly in organic matter loss rather than in changes in organic matter quality. A producers' main concern is to reduce or prevent further organic matter loss. 
Guthrie and Bomke (1980) studied the effects of two nitrification inhibitors, N-Serve, which cannot be conveniently coated on solid fertilizer due to its volatility, and ATC which can because it is nonvolatile and water soluble. Neither inhibitor coated on urea affected nitrification when broadcast on either a silty Rego Humic Gleysol (Fraser Lowland, Delta Municipality) or a loamy sand Humic Podsol. On the Gleysol, both were equally effective in delaying nitrification when banded, however, on the Podsol, ATC had a $\mathrm{NH}_{4} / \mathrm{NO}_{3}$ ratio that was five times higher than $\mathrm{N}$ Serve three weeks after application. The effectiveness of $\mathrm{N}$-Serve to maintain a high ratio persisted longer on the silt ( 86 days) than on the sand ( 23 days), suggesting limited effectiveness on sand. Neither inhibitor significantly improved yield of silage corn on either soil. Guthrie and Bomke (1981), using the surface layer of the same silty Rego Humic Gleysol, indicated that these same inhibitors had no effect on the urea hydrolysis rate at urea application rates 2 or 22 times the recommended rate but the hydrolysis rate at $2^{\circ} \mathrm{C}$ was about half of that at $12^{\circ} \mathrm{C}$.

Bomke and Maynard (1980) studied the response of a grass-legume sward to poultry manure (rates 0 to $40 \mathrm{t} / \mathrm{ha}$ ) applied to an Orthic Gleysol in the Fraser Lowland (Chilliwack District Municipality). The dry matter yield of the orchardgrass component increased with increasing manure rates but at rates above 2.5 tha, ladino clover was nearly eliminated. In the establishment year, total yield from two cuts was 7 tha with application of 40 tha manure, although the rate of yield increase was greatest for rates of 10 tha or less. In the second year, yield was 16 tha with application of 20 t/ha split into three applications and about 1.2 tha higher than a single application of manure at the 5 to 20 tha rates. Manure significantly increased forage nitrogen (crude protein), especially at the 20 tha rate but nitrate-nitrogen did not exceed toxic levels (>0.02\%) even with application of 20 and 40 tha of manure. Good forage yields were obtained with the 10 tha rate without damage to the grass component and without toxic levels of nitrate. However, for manure disposal, rates up to 20 t/ha could be used.

Bomke and Lowe (1991) showed substantial dry matter increases of grass-legume forage to applications of up to 20 t/ha of deep-pit poultry manure on a silty clay loam Orthic Gleysol in the Fraser Lowland near Chilliwack. There was no indication of toxicity for several micro (trace) elements in forage samples even with manure applications of 40 tha but copper and zinc concentrations were increased and manganese to copper ratios tended to decrease.

John (1972) et al. conducted a growth-chamber treatment, including three Gleysols, to study the effects of liming alfalfa. Increased dry matter yields and number of havests were associated with increased rate of lime application. The major benefits were the reduction of aluminum and manganese from toxic levels but a reduction in available forms of iron and zinc also occurred.

Kowalenko et al. (1980) studied residual effects five years after a field trial involving application of coarse limestone at rates from 0 to 44 tha with varying rates of phosphorus, potassium and magnesium on a Rego Humic Gleysol at the Agriculture Canada Research Station at Agassiz, BC. Dry matter yield of oats (grain and straw) decreased with increasing limestone rates, plant manganese and zinc uptake also decreased, and plant concentrations of both elements fell below critical levels for plant growth, which were reflected in extractable soil values only for manganese.

Kowalenko and Maas (1982) conducted a field fertilizer trial with seven fertilizer nutrients on two soils, a Rego Humic Gleysol and a Degraded Eutric Brunisol, for filbert orchards (Fraser Lowland near Chilliwack). There were no significant filbert nut yield responses on these soils; leaf potassium concentration was increased by potassium fertilization on the Gleysol, leaf zinc by zinc fertilization on the Brunisol; in both trials, leaf boron was increased by boron fertilization and leaf 
manganese was increased by nitrogen fertilization and to a lesser extent by potassium fertilization. There was only a limited increase in leaf nitrogen, phosphorus, calcium and magnesium by fertilizer treatment, probably because these nutrients were already adequately supplied by these soils. Positive correlations between soil extraction values and leaf concentrations for phosphorus, potassium and manganese suggest the former as a promising diagnostic method for fertilizer recommendations but not for calcium or magnesium.

Bomke and Bertrand (1983) conducted a field fertilizer trial on Orthic Gleysolic soil (Fraser Lowland, Delta Municipality) on an orchardgrass-perennial ryegrass sward. The trial consisted of four rates of nitrogen, $0,75,150$ and $300 \mathrm{~kg} / \mathrm{ha}$, each rate was applied as urea or ammonium nitrate, either in a single spring application or one-third split in spring and after first and second cuts. There was significant linear dry matter response to applied nitrogen in each of the three years but yield differences between sources and between application methods were obtained in only one of the years. Split applications at every rate of ammonium nitrate gave $8 \%$ higher yield than single applications. In all years, split applications of both sources increased forage yield from cuts two and three.

Many of the crops are cultivated annually. Cultivation, particularly when fine-textured (clayey) soils are too wet, leads to deterioration of soil structure, development of compact layers, especially in the lower part of the cultivated layer and result in reduction of soil water and air permeabilities and holding capacities, all of which result in greater drainage difficulties and decreased crop productivity.

Compact layers will also lead to irrigation problems. Surface applied irrigation water will infiltrate into the soil and move into the lower part of the soil profile only very slowly. Likewise, subirrigation from water provided in drainage ditches and tile systems will move, by capillarity, only very slowly into the upper part of the profile because of restricting compact layers. Root penetration of many annual crops can be severely restricted by compact layers. Roots of certain perennial forages may penetrate and loosen compact layers. However, continued annual cropping and cultivation with inappropriate implements (e.g. moldboard plow) when soils are too wet will develop compact layers in clayey soils, thereby effectively restricting the rooting volume to only part of the cultivated surface layer.

Paul and de Vries (1979a) developed methods to determine soil strength measured by cone penetration resistance and from soil hydrological properties. Paul and de Vries (1979b) further related efficient vehicle traction to water table depth for a Mesisol and a silty clay loam Gleysol. The effect of subsurface drainage allowing for earlier trafficable dates was predicted by two field procedures and confirmed by field observations (Paul and de Vries 1983 a,b).

When cultivated, Organic soils, particularly the shallow Humisols and peaty Gleysols, suffer from organic matter decomposition and subsidence, both of which result in decreased drainage, workability and root penetration into underlying mineral layers. Driehuyzen (1988) discussed water management strategies for organic soils that can reduce decomposition. Low bearing strength is also a characterstic of Organic soils.

A guide (BCMAFF 1989) for commercial vegetable production outlines certain management practices to reduce organic soil loss by decomposition and subsidence, which is continuous at about $1 \mathrm{~cm} /$ year under annually cultivated management systems. Flooding in the winter will reduce this loss but is not recommended because of the compaction and erosion that can result. A practical compromise is to hold the winter water table at about $10 \mathrm{~cm}$ below the surface so that 
decomposition is reduced and a porous surface layer is still maintained. The guide also outlines the use of copper sulfate to reduce decomposition and recommends against the excessive use of rototilling and other traffic to control compaction and decomposition. In commercial practices, however, the copper amendment is rarely used due to cost ( $G$. Hughes-Games, personal communication).

Burns bog is a $25 \mathrm{~km}^{2}$ tract of organic deposit classified as an extremely acíd Typic Fibrisol (Luttmerding 1980a, 1981a, b). About one-half is still in its natural state but would be rated for agriculture as class $02 \mathrm{X}$ and $03 \mathrm{X}$, after improvement (Wood 1981, portion of $92 \mathrm{G} / 2,3$ ). The other half has been disturbed by peat extraction and has a class $03 \mathrm{X}$ after improvement. Improvement costs are considered above average because it is feasible to drain only a large area. However, because of the high CCA of this land area, these soils are capable of growing a wide range of vegetables and forage crops, as well as cranberries and blueberries which require acid soils but not necessarily Organic ones. The bog is adjoined on two sides by currently farmed Agricultural Land Reserve and is close to food markets, transportation and agricultural services (Wood 1981, portion of $92 \mathrm{G} / 2,3$ ). A large portion of Burns Bog now consists of a garbage landfill for the Vancouver Regional District. Maynard (1988) reported that the accessible peat deposits of the lower Fraser Valley (Burns bog being the largest) and of eastern Vancouver Island have been largely depleted and/or pre-empted for sphagnum peat (horticultural) extraction.

In the Chilliwack (Comar et al. 1962, portions 92 G/1, H/4. 1:24 000) and Agassiz (Luttmerding and Sprout 1967, portions $92 \mathrm{H} / 4,5$ and 6. 1:24 000) areas, Humic Gleysols and Terric and Typic Humisols will grow a wide range of crops where adequate drainage is provided in the Class 1 CCA. Supplemental irrigation may be economical in some years, especialiy on coarse textured Gleysols or those with sand or gravel lenses. Rego Gleysols may often be difficult to drain due to undulating topography, inadequate natural outlets or because they occur in small scattered areas. The strongly acid Humisols are suitable for blueberries.

Maas (1972) reported and discussed agricultural interpretations of field, chemical and physical characteristics of 41 Organic soil sites from four agricultural areas of southeastern Vancouver Island, paying particular attention to the effects of wetting and drying on bulk density, shrinkage and subsidence of various kinds of peats encountered. He further discussed management considerations, including conservation and drainage, irrigation, crop selection, as well as soil fertility and fertilization of the poorly decomposed (bog peat) and well decomposed (marsh peat) Organics.

On southeastern Vancouver Island, soil moisture deficiency could be minimized for potatoes by confining the crop to Organic soils (Maas 1963). Moisture is usually adequate on deep Organics (Typic Mesisols, i.e. Arrowsmith, Jungen et al. 1985) but not on shallow Organics (Typic Humisols, shallow phase, i.e. Metchosin, Jungen et al. 1985). Maas' (1963) recommendation, based on field trials with the Netted Gem potato cultivar and favoring large and medium sized marketable tubers, was to plant whole-seed tubers at $50 \mathrm{~cm}$ spacing (rows $90 \mathrm{~cm}$ apart) on either soil. On the Metchosin soil, cull yield was not affected by either spacing differences (30 to $60 \mathrm{~cm}$ ) or nitrogen fertilization rates but on Arrowsmith soil, cull yield was increased with wider spacing and the highest nitrogen rate. Further field trials showed that the high nitrogen rate increased yield but decreased tuber specific gravity on an Organic soil cultivated for 10 years but not on a recently cultivated soil (Maas 1968). These responses were related to nitrate-nitrogen release rates measured by growth chamber and laboratory incubation tests. Different methods of nitrogen placement, including urea foliar spray, did not increase tuber yield. 
Organic soils of the Gulf Islands survey area (van Vliet et al. 1987, 1991; Kenney et al. 1988, 1990; Green et al. 1989; portions of $92 \mathrm{~B} / \mathrm{NW}, 92 \mathrm{G} / 4,1: 20000$ ) are dominated by very strongly to strongly acid Typic Humisols and have little agricultural use except for blueberry and cranberry production. These soils require lime (except for blueberry and cranberry) and macronutrients for maximum production. When phases with diatomaceous earth or sedimentary peat near the surface are tilled, these materials dry and become difficult to rewet and breakdown (Kenney et al. 1988). Humic Luvic Gleysols underlain by silty clay loam marine deposits are one of the most important agricultural soils, particularly on Saltspring (van Vliet et al. 1987), Galiano (Green et al. 1989) and Gabriola and lesser Islands (Kenney et al. 1990) Islands. Undrained, the use of these soils is limited to hay and pasture but, if drained and adequately fertilized, a wide variety of crops may be grown on these acid soils. Orthic Humic Gleysols are generally used very little because they often occur in small pockets frequently between rock ridges and are difficult to drain so are left under natural vegetation to be used for hay or pasture.

Jungen et al. (1985; portions $92 \mathrm{~B} / \mathrm{NW}, \mathrm{F} / 1$ and 8, G/4 and 5, 1:20 000) indicated that Orthic Humic Gleysols developed on marine or marine/fluvial materials, or Humic Luvic and Rego Humic Gleysols on marine materials, and Typic Humisols and Typic Mesiscls in their surveyed area of southeastern Vancouver Island are capable of growing a wide range of crops when adequately drained. The strongly acid Humisols are well suited to blueberries. Coarse textured Orthic Humic Gleysols suffer from drought and often occur in small scattered areas so are unsuitable for agriculture.

Cranberries have experienced die-back problems growing on a Vancouver Island organic soil developed on a nonfibrous compact sedimentary peat deposit, even though the peat is acid. The difficulty may have resulted from irrigation water which was high in sodium, as well as the very slow rewetting of the peat soil after it had dried. Cautious implementation of certain practices was recommended (Green 1988, portion 92 F/14). Tarnocai and Schuppli (1987) discussed the characteristics and development of acidic Canadian sedimentary peats, including three soil profiles from southern Vancouver Island.

\subsection{Interior Plateau, North}

Extent The extent of the north Interior Plateau, Chilcotin-Cariboo portion roughly coincides with the combined extent of the Fraser Plateau and Quesnel Highland physiographic subdivisions (not shown on Figs. 2-7) of the Interior Plateau. That of the Central Interior portion roughly coincides with those of the Nechako and McGregor Plateaux, Fraser Basin and Nechako Plain (not shown) subdivisions (Holland 1976).

Wetlands of the north Interior Plateau cover $6075 \mathrm{~km}^{2}$ (Table 6) and account for $4 \%$ of the total land area of this group and $12 \%$ of $\mathrm{BC}$ wetland area (Table 1). The concentration of wetlands in the Chilcotin-Cariboo and Central Interior portions of this group are about the same, $4 \%$ (Table 6). Most of the wetlands of the Chilcotin-Cariboo are above $900 \mathrm{~m}$ elevation $(60 \%$ between 900 and $1200 \mathrm{~m}$ ) while most of those of Central Interior are between 600 and $1200(70 \%$ between 600 and $900 \mathrm{~m}$ ). The proportion of Gleysols is somewhat less for the Chilcotin-Cariboo portion (29\%) than for the Central Interior (36\%) (Figs. 2-4). However, the small area of wetlands in the 300 to $600 \mathrm{~m}$ elevation range is dominated by Gleysols in both portions (Figs. 4,5,9). 
Table 6. Elevational distribution of wetland area in $\mathrm{km}^{2}$ and $\%$ of total map area for the Interior Plateau, north group'.

\begin{tabular}{|c|c|c|c|c|c|c|}
\hline \multirow{2}{*}{$\begin{array}{l}\text { Wetland } \\
\text { category }\end{array}$} & \multirow{2}{*}{$\begin{array}{l}\text { Total } \\
\text { map } \\
\text { area }\end{array}$} & \multicolumn{5}{|c|}{ Elevation category $(\mathrm{m})$} \\
\hline & & $300-600$ & $600-900$ & $900-1200$ & $>1200$ & Total \\
\hline & \multicolumn{6}{|c|}{ Chilcotin-Cariboo portion } \\
\hline \multirow[t]{2}{*}{ Total } & 63877 & 2 & 190 & 1511 & 886 & 2589 \\
\hline & 100 & $<0.1$ & 0.3 & 2.4 & 1.4 & 4.1 \\
\hline \multirow[t]{2}{*}{ Organic } & 43965 & 0 & 132 & 829 & 296 & 1257 \\
\hline & 100 & 0.0 & 0.3 & 1.9 & 0.7 & 2.9 \\
\hline \multirow[t]{3}{*}{ Gleysol } & 43965 & 2 & 48 & 308 & 166 & 523 \\
\hline & 100 & $<0.1$ & 0.1 & 0.7 & 0.4 & 1.2 \\
\hline & \multicolumn{6}{|c|}{ Central Interior portion } \\
\hline \multirow[t]{2}{*}{ Total } & 87839 & 39 & 2266 & 950 & 231 & 3486 \\
\hline & 100 & 0.0 & 2.6 & 1.1 & 0.3 & 4.0 \\
\hline \multirow[t]{2}{*}{ Organic } & 51488 & 6 & 1171 & 534 & 74 & 1785 \\
\hline & 100 & 0.0 & 2.3 & 0.1 & 0.1 & 3.5 \\
\hline \multirow[t]{2}{*}{ Gleysol } & 51488 & 33 & 790 & 144 & 52 & 1019 \\
\hline & 100 & 0.1 & 1.5 & 0.3 & 0.1 & 2.0 \\
\hline
\end{tabular}

'See Fig. 8. Organic and Gleysolic wetland areas derived from Soil-CLI surveyed map sheets (Fig. 1).

Wetland Region The continental Mid-Boreal WR coincides closely with the northern part of the Chilcotin-Cariboo and Central Interior portions of the north Interior Plateau (NWWG 1986). Flat and basin bogs occur in association with horizontal and ribbed fens at high elevations. Plateau bogs occasionally occur in large fens. Marshes are found along gently sloping lake shores. Peat thickness averages $4 \mathrm{~m}$. The southern part of the Chilcotin-Cariboo is covered by the northern part of the Intermountain Prairie WR which contains marshes, usually bordering fresh to saline ephemeral or semipermanent shallow water, in a semi-arid climate and peat development is generally absent. However, at higher elevations, Organic soils have been noted in the southern part of this WR (Young and Fenger 1992; $92 \mathrm{I}$ ).

Climate Climate varies with elevation, latitude and distance from the Coast Mountains (Table 7, Fig. 8). Decreases in GDD and FFP occur with increases in elevation and latitude, and the $\mathrm{CMB}$ increases (becomes wetter). However, the rain shadow effect of the Coast Mountains is dramatically illustrated by comparison of $\mathrm{CMB}$ for two stations at roughly similar elevation, Big Creek $(-235 \mathrm{~mm})$ on the western edge of the Interior Plateau with Barkerville $(+165 \mathrm{~mm})$ on the eastern edge, adjacent to the Columbia Mountains. Improved (irrigated) CCA was rated 3 or better for stations below 700 m elevation (Williams Lake, Quesnel, Prince George, Telkwa and Fort St. James). An unimproved CCA rating of 5 or poorer was given to certain stations at 900 $\mathrm{m}$ or higher elevation (Kleena Kleene, Big Creek, Barkerville). However, just beyond the extreme 
north of the Central Interior portion at $747 \mathrm{~m}$, Germansen rated CCA class 5 but in the extreme south of the Chilcotin-Cariboo portion at $848 \mathrm{~m}$, Tatlayoko rated CCA 4 (improved, irrigated).

Many of the wetlands of Chilcotin-Cariboo portion rate CCA class 4 or poorer because they are mostly above $900 \mathrm{~m}$. A large part of the wetlands of the Central Interior portion would rate up to CCA class 4 because they occur in the vicinity of Prince George and Fort St. James (Fig. 2) where elevations are lowest, ranging between 600 and $900 \mathrm{~m}$ (Fig. 9). The remaining wetlands of the Central Interior portion would rate CCA class 4 or poorer. The poor ratings are due to reduced frost free periods and/or insufficient heat units.

An improved rating for irrigated as well as drained wetlands was given for Organics lying west of an anecdotal southeast-northwest line through Horsefly (Fig. 8) where aridity is a serious limitation (BCME 1976). The line roughly divides the arid interior from the "wet belt" of the interior.

Wetland SoilWetlands have been particularly important in the Chilcotin-Cariboo where livestock production has been practiced for over a century, beginning with the use of native wetland forage species, especially the sedges and grasses, for summer grazing and winter feeding. Therefore if about half of the livestock feed supply of the Chilcotin-Cariboo is produced on wetlands, then the importance to the BC cattle industry of wetlands is illustrated by the 1986 census of agriculture which indicated that $22 \%$ (about 46550 head) of the total BC beef cow herd was raised in the Cariboo agriculture region by 535 reporting producers (Talisman 1989; summary table, detailed producer file). Talisman (1989) also indicated that in 1986, Cariboo beef producers had the lowest "cropping expense per animal unit" ( $\$ 130 /$ head), the lowest "cropping expense per animal unit month" (grazing season, $\$ 10 / \mathrm{AUM}$ ), and the lowest "feed expense per animal unit" $(\$ 70 /$ head), except for the Peace area $(\$ 65 /$ head). The average for all BC beef producers was $\$ 167 /$ head, $\$ 13 / A \cup M$ and $\$ 116 /$ head, respectively for the expenses listed above. Average farm value (1985) however was the highest $(\$ 14063)$ for the South Interior reporting region followed by the Cariboo ( $\$ 11274$ ) as compared to the BC average ( $\$ 8500$ ). Further documentation indicated that the Cariboo Regional District has been a prime beef production area for over 140 years, has the opportunity for further development, and will remain an integral part of the economy of the district (Equus 1990; Telford 1991).

Recently, Sparks/KenAgra (1992) concluded that feed availability and cost are the most important factors influencing profitability within the various segments of the beef producing industry. Next to the Peace River and north-central Alberta regions, the Bulkley-Nechako and Cariboo (i.e. Central BC and Chilcotin-Cariboo) regions have the most suitable situations for the cow-calf segment because of the availability of low-cost forage for grazing and stored winter feed. However, all BC regions are at a disadvantage for drylot-backgrounding operations because inexpensive grain feeds and processor wastes are not readily available. Within BC, other than the Peace region, drylot-backgrounding is the most competitive in the Central $\mathrm{BC}$ and ChilcotinCariboo because irrigation costs (not usually necessary on wetlands) are higher in the ThompsonOkanagan and Kootenay regions and other production costs are higher in the Lower Fraser Valley. 
Table 7. Elevation, climatic parameters and climatic capability for agriculture of selected stations ${ }^{1}$ for Interior Plateau, north and south groups.

\begin{tabular}{|c|c|c|c|c|c|c|}
\hline Station & $\begin{array}{c}\text { Elevation } \\
\mathrm{m}\end{array}$ & $\begin{array}{l}\text { Growing } \\
\text { degree } \\
\text { days } \\
\left(>5^{\circ} \mathrm{C}\right) \\
{ }^{\circ} \mathrm{C} \text { day }\end{array}$ & $\begin{array}{c}\text { Freeze free } \\
\text { period } \\
\left(<0^{\circ} \mathrm{C}\right) \\
\text { day }\end{array}$ & $\begin{array}{c}\text { Climatic } \\
\text { moisture } \\
\text { balance } \\
\text { mm }\end{array}$ & $\begin{array}{l}\text { Climatic } \\
\text { for agri } \\
\text { Improved } \\
\text { class }^{2}\end{array}$ & $\begin{array}{l}\text { apability } \\
\text { ulture } \\
\text { Unimproved } \\
\text { class }^{2}\end{array}$ \\
\hline & \multicolumn{6}{|c|}{ Interior Plateau, north } \\
\hline & \multicolumn{6}{|c|}{ Chilcotin-Cariboo portion } \\
\hline Williams Lk. A. & 674 & 1404 & 101 & -157 & $1 \mathrm{GF}$ & $3 A$ \\
\hline Tatlayoko Lk. & 848 & 1128 & 57 & -301 & $4 \mathrm{~F}$ & $5 A$ \\
\hline Kleena Kleene & 899 & 935 & 25 & -314 & & $6 \mathrm{~F}$ \\
\hline \multirow[t]{2}{*}{ Big Creek } & 1134 & 984 & 41 & -235 & & $5 \mathrm{GF}$ \\
\hline & \multicolumn{6}{|c|}{ Central Interior portion } \\
\hline Quesnel A. & 545 & 1425 & 98 & -165 & $1 \mathrm{GF}$ & $3 A$ \\
\hline Prince George A. & 676 & 1181 & 78 & -68 & $2 G F$ & 2AGF \\
\hline Telkwa & 683 & 1077 & 80 & -137 & $3 G$ & $3 A G$ \\
\hline Fort St. James & 686 & 1069 & 76 & -124 & $3 G$ & $3 A G$ \\
\hline Germansen Lndg. & 747 & 894 & 54 & -116 & & $5 G$ \\
\hline Wistaria & 873 & 923 & 67 & -112 & & $5 G$ \\
\hline \multirow[t]{2}{*}{ Barkerville } & 1274 & 732 & 47 & +165 & & $6 G$ \\
\hline & \multicolumn{6}{|c|}{ Interior Plateau, south } \\
\hline Oliver & 305 & 2225 & 137 & -498 & $1 \mathrm{aF}$ & $7 A$ \\
\hline Kamloops CDA & 351 & 2337 & 152 & -444 & $1 b E$ & $7 \mathrm{~A}$ \\
\hline Coldstream Ranch ${ }^{3}$ & 482 & 1905 & 153 & -295 & $1 \mathrm{bG}$ & $5 A$ \\
\hline Blue River & 689 & 1288 & 106 & +5 & & $2 G$ \\
\hline Osprey Lake ${ }^{4}$ & 1098 & 1810 & 62 & -58 & & $3 F$ \\
\hline Nickel Plate & 1767 & 526 & 32 & & & $6 \mathrm{GF}$ \\
\hline
\end{tabular}

${ }^{1}$ From BCME (1981), Station locations indicated on Fig. 8.

${ }^{2}$ Class limitation indicated by $\mathrm{A}$-aridity (negative climatic moisture balance), E-extreme minimum winter temperature, F-reduced freeze free period, G-insufficient heat units (growing degree days).

${ }^{3}$ Vernon.

${ }^{4}$ From Lord and Green (1974). Climatic capability estimated.

${ }^{5}$ From Green and Lord (1979). Growing degree days $>5.6^{\circ} \mathrm{C}$. Climatic capability estimated. 
Most wetlands occur in the middle and higher elevations where the climate is suited only for forage and possibly coarse grain (barley and oat) production. These climatic limitations were summarized in map and tabular form by agriculture land capability classes for Cariboo and Omineca agriculture reporting regions (BCMAFF 1976) which cover most of the north Interior Plateau.

Levesque et al. (1987) described and analyzed in detail two contrasting groups of Mesisols and Humisols. The first group included grassy sedge peats and mossy sedge peats of the Interior Plateau fens; the other included woody sedge peats and ericaceous sphagnum peats of the southwest coast. Most soils of both groups were underlain by sedimentary (limnic) peats but soils of the coastal group were overlain by peat materials more acidic than those of the interior. The Mesisols of the Interior Plateau had thicker organic overlays that subsided less than did those of the degraded coastal Humisols, which had developed a shallow compact layer over the limnic layer. Levesque et al. (1987) concluded that the intensive cropping management of the southwest coast was considerably more conducive to degradation and decomposition of peat than was the perennial forage production systems used for wetland soils of the Interior Plateau. These forage production systems represent the most benign and natural use of these soils by agricultural producers.

Gough (1988 92 P?E) discussed soil and climatic capabilities for agriculture in the Bonaparte River - Canim Lake map area, $32 \%$ of which rates capability class 1 to 5 . He furhter indicated crop suitablity for each soil map unit and its geographic location. Similarly engineering and forestry capabilities were given. Dawson (1989 $93 \mathrm{G} / \mathrm{N}, \mathrm{J} / \mathrm{S}$ ) presented a similar discusion for Prince George - McLecd Lake map area.

At the higher elevations of the Interior Plateau and Chilcotin River Valley, about $65 \%$ of the total wetlands can be utilized for hay production and pasture for domestic livestock with native vegetation or established cultivars (CCA class 4 to 6 ). CCA class 1 occurs on less than $5 \%$ of the area along the fluvial benches of the Fraser River at low elevations (Lord and Walmsley $1988 \mathrm{~b}, 93 \mathrm{~B} / \mathrm{S})$. The main factor that restricts the CCA at the Canim Lake No. 1 Indian Reserve is short FFP but certain cool season vegetables will grow well on some of these soils if water control devices can be installed (Leskiw and Farstad 1973, portion $92 \mathrm{P} / 14 \mathrm{E}, 15 \mathrm{~W}$ ). Hay can be produced from native vegetation on the better portions of the poorly drained bottom lands on the Williams Lake No. 1 (Sugar Cane) Indian Reserve, but fertilization has been recommended (Leskiw et al. 1973a; portion $93 \mathrm{~A} / 4, \mathrm{~B} / 1$ ).

Wetlands are especially valuable in the arid southwest of the Interior Plateau. At locations where water control structures can be economically constructed by producers, using their own resources to remove excess water and to retain storage water for use by subirrigation or flooding during drought periods, production can be maintained. Such structures are also important for the prevention of peat fires in the wetlands, such as occurred during the drought period of the 1930's, particularly in the Sub-boreal Pine - Spruce BGCZ. Driehuzen (1982) reported preliminary trials, with slotted plastic drain tubing, conducted west of Williams Lake.

Management practices that have proven useful for forage production on Organic soils of the Interior Plateau include water control, selection and establishment of introduced cultivated species, and fertilization (Cariboo Poorly Drained Soils Development Extension Committee 1992). The recommended introduced grass species (cultivars) include reed canarygrass (Phalaris arundinacea) and creeping foxtail (Alopecurus arundinaceus var. Garrison). These produce better yield and quality feed than most native species when adequately fertilized. Two hay cuttings, or one cutting plus a substantial regrowth, can be realized at elevations up to about $900 \mathrm{~m}$. Between 
900 and $1200 \mathrm{~m}$, usually only one cutting is obtained from introduced species. Above $1500 \mathrm{~m}$, cultivar introduction would not likely be economical.

Harmful alkaloids characteristic of reed canarygrass rarely reach toxic levels when this species is grown on wetlands (Majak et al. 1979a,b). Certain native sedges and grasses (unfertilized) adapted to the more fertile Humisols and Humic Gleysols at low elevations will produce yields nearly as high as yields from fertilized introduced grasses on Mesisols or Fibrisols (van Ryswyk 1988). The areal extent of these humic soils however is rather limited.

The Engineering Branch of the BCMAFF has recently developed a wetland plow, based partly on previous producer experience (van Dalfsen 1989). It has successfully operated for three years to severely retard all existing native vegetation and leave the overturned sod firm enough to allow for good trafficability. Alternate procedures of rototilling or discing do not usually retard vegetation adequately and leave the soil loose with poor trafficability, particularly when wet. The final important step for seedling establishment, after seeding and fertilizing, is to firmly pack the surface soil to allow moisture to move through the surface by capillarity and prevent dessication of seedling plants. This is difficult to achieve after rototilling because the pre-existing sod is severely broken (Cariboo Poorly Drained Soils Development Committee 1992).

Experimental trials to assess the fertilizer nutrient requirements of several Organic soils were conducted in the growth room using native sedge and reed canarygrass (Pringle and van Ryswyk 1965; van Ryswyk et al. 1974) and in the field (Pringle and van Ryswyk 1968; van Ryswyk 1988). Mesisols require higher rates of nitrogen, phosphorus and potassium fertilizer than Humisols to achieve maximum yields. One deep-plowed Mesisol required sulfur for production of reed canarygrass for two years following cultivar establishment. Lime (calcium) was of little benefit for the soils tested with near neutral reaction $(\mathrm{pH})$.

Pringle and van Ryswyk (1968) reported a significant carryover effect of phosphorus and potassium fertilizer for several years during field trials but showed that the main effect of nitrogen usually lasted only one year on a sedge-grass stand on a Mesisol. Fertilized and unfertilized sedge-grass hays from a Mesisol gave the same liveweight gains when fed to yearling steers. This indicated that quality of forage was not improved with fertilization but that only forage quantity was greatly increased, average of $3800 \mathrm{~kg} / \mathrm{ha}$ compared to $1400 \mathrm{~kg} / \mathrm{ha}$ for unfertilized during a two-year study (van Ryswyk et al. 1973).

Lowe and Milne (1979) conducted a survey of extractable soil micronutrients for a group of soils from the Vanderhoof-Fort Fraser area west of Prince George. Only two Organic soils were included which averaged, on a weight basis, $14.6 \mathrm{ppm}$ copper, 3.6 zinc and 17.6 manganese compared to the average for 39 mineral soils, $0.7 \mathrm{ppm}$ copper, 2.5 zinc and 15 manganese. However, since bulk densities of Organic soils are much lower (Mesisols, 0.075 to $0.195 \mathrm{gm} / \mathrm{cm}^{3}$, ACECSS 1987) than those of mineral soils (about $1.0 \mathrm{gm} / \mathrm{cm}^{3}$ ), the values for Organic soils, on a volume basis, would be reduced by a factor of about 0.1 to 0.2 . Thus all of these soils would be considered low in extractable copper $(<2 \mathrm{ppm})$ compared to a group of soils from the Lower Fraser Valley $(3.6 \mathrm{ppm})$. In the same study, the authors indicated that 30 samples of timothy and/or bromegrass forage averaged $4 \mathrm{ppm}$ copper, a minimum recommended level for beef cattle feed and well below $10 \mathrm{ppm}$ for dairy cattle feed (National Academy of Science - National Research Council (NAS-NRC) 1976), and averaged 23 ppm zinc, well below the recommended minimum of $50 \mathrm{ppm}$ (NAS-NRC 1976). These results substantiated findings by Miltimore et al. (1970) on 254 grass or sedge hay samples collected throughout B.C. They found $97 \%$ of the samples were below the recommended (NAS-NRC 1976) $10 \mathrm{ppm}$ copper, $96 \%$ below recommended $50 \mathrm{ppm}$ zinc but only $23 \%$ below recommended $30 \mathrm{ppm}$ iron. However, the sedge 
hays grown on wetland sites were a small portion of the grass-sedge group. Miltimore et al. (1975) analysed selenium in a group of B.C. feeds, including 46 sedge hays, most of which came from wetlands of the Chilcotin-Cariboo, and averaged $0.13 \mathrm{ppm}$ selenium with $76 \%$ below the recommended $0.1 \mathrm{ppm}$ level (NAS-NRC 1970). Although these micronutrients were below recommended levels for livestock feed, supplementation of feeds grown on wetlands by supplying appropriate mineral salts directly to livestock is the most economical solution. The few field fertilizer trial treatments that have included micronutrients did not show any significant yield increases on wetland soils.

Agriculture development on wetlands in the Central Interior portion has been limited mainly to use of native forage species for grazing or hay. Authors of most of the soil survey reports indicated the development costs for water control were not considered economically feasible at the times of the surveys. The main climatic limitation was a short frost free season that may be even shorter where these soils are located in frost pooling pockets compared to adjacent uplands. However, with more modern machinery, wetland development is becoming economically feasible, particularly for small-area projects that can be done by an individual producer on his own land. This is particularly true when the project will result in more livestock feed produced on a smaller area close to ranch headquarters.

Maynard (1988) explained that large fens and contiguous peatlands in central BC (roughly bounded by the north Interior group) could provide potentially good sources of fuel peat because climate, access and transportation facilities are good. However, good sources of horticultural peat are limited.

\subsection{Interior Plateau, South}

Extent The south Interior Plateau wetlands cover $1016 \mathrm{~km}^{2}$ or nearly $2 \%$ of this group's total land area and $2 \%$ of $\mathrm{BC}$ wetland area (Table 1,8). The largest area (1\%) occurs above $1200 \mathrm{~m}$ and the next largest (0.6\%) between 300 and $600 \mathrm{~m}$ (Table 8 ). Gleysolic soil areas are equal to or dominate over Organic areas, particularly between 300 to $600 \mathrm{~m}$ (Fig. 4,5). The small area of Gleysols that occurs below $300 \mathrm{~m}$ is located in the south Similkameen and Okanagan Valleys.

Wetland Region The south Interior Plateau group is covered almost entirely by the Intermountain Prairie Wetland Region (NWWG 1986) with wetlands similar to those of the southern part of the Chilcotin-Cariboo portion of the north Interior Plateau. Peat development is generally absent, except at high elevations (Young and Fenger 1992; 92 I).

Climate Climate is dominated by aridity resulting from the rain shadow effect of the Coast and Cascade Mountains. Generally GDD and FFP decrease while CMB increases from south to north and with increasing elevation (Table 7, Fig. 8).

Wetland soil A series of interim soil survey reports were prepared by the BCMAFF, Soils Branch during the 1950's and 1960's for arable/irrigable land in many of the major and tributary valleys in the southern part of $\mathrm{BC}$, including those of the Mountain physiographic subdivision group. Under the auspices of a Reclamation Committee, a series of proceedings outlined in detail soil capability ratings for irrigated agriculture and irrigation water requirements for described soil map units. These proceedings complemented the soil survey reports. None of the Reclamation Committee's proceedings and only certain interim soil survey reports, wherein agricultural use information would supplement that of subsequent reports, are referred to in this section. 
However, some of these reports and proceedings may still be found at relevant BCMAFF district offices.

Saline and calcareous phases of Gleysols in the Ashcroft-Savona area, 320 to $700 \mathrm{~m}$, were considered irrigable in this area of high moisture deficit (CMB approx. $-400 \mathrm{~mm}$ ) although these soils would probably be restricted to appropriate forage crops and would require subdrainage to remove salts (Sprout and Kelley 1963, portion $92 \mathrm{I} / 10,11,14,15)$. Young and Fenger (1992, $92 \mathrm{I}$ ) indicated that Typic Mesisols occur between 1200 to 1830 m, CCA Class 6 but Humic Gleysols and Gleyed Regosols (improved CCA class 4 to 5) occur between 330 and $480 \mathrm{~m}$ in the main valley bottoms. Humic Mesisol (muck) soils of the Eagle River Valley, 1140 to $1750 \mathrm{~m}$ elevation, are considered excellent for vegetables when adequately drained and fertilized (Dawson and Kelley 1964, portion 82 L/15). Gleysols and Humic Gleysols of the Shuswap Lakes area, 500 to $700 \mathrm{~m}$, are also arable (improved CCA class 3 to 5) although certain areas are hard to drain (Dawson and Kelley 1965, 92 L/NW and portion L/6).

Table 8. Elevational distribution of wetland area in $\mathrm{km}^{2}$ and $\%$ of total map area for the Interior Plateau, south group'.

\begin{tabular}{|c|c|c|c|c|c|c|c|}
\hline \multirow{2}{*}{$\begin{array}{l}\text { Wetland } \\
\text { category }\end{array}$} & \multirow{2}{*}{$\begin{array}{l}\text { Total } \\
\text { map } \\
\text { area }\end{array}$} & \multicolumn{6}{|c|}{ Elevation category $(m)$} \\
\hline & & $0-300$ & $300-600$ & $600-900$ & $900-1200$ & $1200+$ & Total \\
\hline & 52344 & 18 & 317 & 74 & 105 & 502 & 1016 \\
\hline Total & 100 & $<0.1$ & 0.6 & 0.1 & 0.2 & 1.0 & 1.9 \\
\hline & 51390 & 0 & 43 & 19 & 48 & 266 & 376 \\
\hline Organic & 100 & 0.0 & 0.1 & 0.0 & 0.1 & 0.5 & 0.7 \\
\hline & 51390 & 18 & 274 & 55 & 53 & 236 & 635 \\
\hline Gleysolic & 100 & $<0.1$ & 0.5 & 0.1 & 0.1 & 0.5 & 1.2 \\
\hline
\end{tabular}

${ }^{1}$ See Fig. 8. Organic and Gleysolic wetland areas derived from Soil-CLI surveyed map sheets (Fig. 1).

Much of the area of wetlands of the North Okanagan Valley was cultivated during the early European settlement period (Sprout and Kelley 1960, portion 82 L/2,3,6,7,11,10). Crops utilized in this area are dependent on soil texture and on the hazards of frost, water table, or alkalinity/salinity/calcareousnous. Irrigation is often needed on both Gleysols and Organics in the latter part of the season when the water table drops below the root zone, particularly on the medium to coarse textured soils. Surface water drainage installations are usually necessary. Underdrainage may be required to control salinity. When the organic layers have decomposed to muck (humic material), the resultant higher fertility produces good yields of those forage and vegetable crops which are suited to the climate.

Much of the drier portions of the wetlands of the Okanagan and Similkameen Valleys have been cleared of forest, drained and used for a wide range of vegetable, cereal and forage crops because of the suitable climate (Kelley and Spilsbury 1949). Wittneben (1986) also reported that vegetable and forage crops can grow on certain drained calcareous and saline phases of Gleysolic soils but that tree fruits do not do well on these soil phases. Grapes are not well suited to any of the wetland soils because of wetness, coldness or salinity (Agriculture Canada 1984). 
The wetlands of the Tulameen and Princeton areas at the lower elevations would rate CCA class 2 or 3 (drained) and those at higher elevations class 4 or 5 (drained). Most are used for forage production in their natural state but those at lower elevations can produce cultivated grain and forage crops (Lord and Green 1974, Green and Lord 1979). Peaty Gleysols and Mesisols of the Kettle River Valley and tributaries, 600 to $1200 \mathrm{~m}$, allow a wide range of crops without the need for irrigation, albeit forest clearing costs are high. Carbonated Gleysols can support only appropriate forage crops (Sprout and Kelley 1964, portions 82 E/1,2,7-10).

Care should be taken to preserve organic matter so that water holding capacity and soil structure are maintained. Excessive cultivation and draining enhances aeration and subsequent organic matter decomposition, leading to rapid soil structure deterioration. This aspect of soil management is particularly important for wetland soils at lower elevations in the major valleys of the southern part of $B C$ where the yearly climate is relatively warmer than for the rest of $B C$, thereby promoting greater organic matter decomposition.

With the exception of the Thompson and Okanagan Valleys and tributaries, the agricultural use of wetlands in the south Interior Plateau is mainly for grazing in the natural state. The productivity and response to commercial fertilizer of an acid Hydric Mesisol, with mainly sedge vegetation at $1460 \mathrm{~m}$, has been reported by McLean et al. (1963). Further growthroom trials (van Ryswyk et al. 1974) and field trials (van Ryswyk 1988) indicated that nitrogen (reapplied annually), phosphorus and potassium were required to produce near maximum yields from the test crop reed canarygrass on most Organic soils below $1200 \mathrm{~m}$ and the addition of lime was also required on acid soils from $1460 \mathrm{~m}$ elevation.

\subsection{Northwestern Plateaux and Basin}

Extent Wetlands of the northwestern Plateau and Basin occupy $841 \mathrm{~km}^{2}$, accounting for about $1 \%$ of this group's total land area for both the Yukon-Stikine Plateau and the Nass Basin, and for $2 \%$ of $B C$ wetland area (Table 1). Most of the recorded wetlands occur between 600 and $1200 \mathrm{~m}$ except for those in the Nass Basin that occur below $600 \mathrm{~m}$ (Fig. 2,4,6).

Wetland Region The Central Interior Mountain WR (NWWG 1986) covers most of this group. Flat bogs, horizontal and ribbed fens with delta marshes, flood plains and shallow basin marshes occur in valleys. Small basin bogs and fens occur in alpine areas. Average peat thickness is usually 2-3 m. The Nass Basin is generally covered by the Continental Mid-Boreal WR. Flat and basin bogs are associated with horizontal and ribbed fens, plateau bogs occassionally occur in larger fens. Marshes can be found along gently sloping lakeshores. The average peat thickness is approximately $4 \mathrm{~m}$. Permafrost is absent in both of these WR.

Climate Climate of a major portion of the northern part of the northwestern Plateaux system is illustrated by the data for Dease Lake $(816 \mathrm{~m})$ which indicate CCA class 6G (Table 9). In contrast, the data for New Hazelton $(314 \mathrm{~m})$ at the southeastern edge of the Nass Basin in the Bulkley Valley show improved CCA class $2 \mathrm{G}$.

The Telegraph Creek area in the Stikine River Valley is a notable exception, where a warm variant of the Boreal Black and White Spruce BGCZ occurs on the lower slopes and terraces which are rated CCA class 2C (Pojar et al. 1983). Runka (1972) indicated CCA class 3 to 4 (unimproved) for a southern portion of Nass Basin in the main valley of the Kispiox and Babine River tributaries of the Skeena River. 
Table 9. Elevation, climatic parameters and climatic capability for agriculture for selected stations ${ }^{1}$ for northern and Mountain groups.

\begin{tabular}{|c|c|c|c|c|c|c|}
\hline \multirow[b]{2}{*}{ Station } & \multirow[b]{2}{*}{$\begin{array}{c}\text { Elevation } \\
\mathrm{m}\end{array}$} & \multirow{2}{*}{$\begin{array}{l}\text { Growing } \\
\text { degree } \\
\text { days } \\
\left(>5^{\circ} \mathrm{C}\right) \\
{ }^{\circ} \mathrm{C} \text { day }\end{array}$} & \multirow{2}{*}{$\begin{array}{c}\text { Freeze free } \\
\text { period } \\
\left(<0^{\circ} \mathrm{C}\right) \\
\text { day }\end{array}$} & \multirow{2}{*}{$\begin{array}{c}\text { Climatic } \\
\text { moisture } \\
\text { balance } \\
\mathrm{mm}\end{array}$} & \multicolumn{2}{|c|}{$\begin{array}{l}\text { Climatic capability } \\
\text { for agriculture }\end{array}$} \\
\hline & & & & & $\begin{array}{l}\text { Improved } \\
\text { class }^{2}\end{array}$ & $\begin{array}{c}\text { Unimproved } \\
\text { class }^{2}\end{array}$ \\
\hline & \multicolumn{6}{|c|}{ Northwestern, Plateaux and Basin } \\
\hline \multirow{3}{*}{$\begin{array}{l}\text { New Hazleton } \\
\text { Dease Lake }\end{array}$} & 314 & 1247 & 93 & -135 & $2 \mathrm{G}$ & $3 \mathrm{~A}$ \\
\hline & 816 & 757 & 44 & -81 & & $6 \mathrm{G}$ \\
\hline & \multicolumn{6}{|c|}{ Liard Plain } \\
\hline \multirow{3}{*}{$\begin{array}{l}\text { Smith River(Army) } \\
\text { Watson Lake } A^{3} \\
\text { (Yukon) }\end{array}$} & 673 & 888 & 52 & -53 & & $5 \mathrm{G}$ \\
\hline & 685 & 973 & 93 & & & $5 G^{4}$ \\
\hline & \multicolumn{6}{|c|}{ Mountain } \\
\hline Mt. Lemoray ${ }^{5}$ & 680 & 1078 & $96^{4}$ & $+56^{4}$ & & $3 G^{4}$ \\
\hline Pine Pass ${ }^{5}$ & 945 & 810 & 79 & +299 & & $5 G^{4}$ \\
\hline Pine $4500^{5}$ & 1363 & 587 & $48^{4}$ & & & $7 G^{4}$ \\
\hline Revelstoke & 456 & 1856 & 140 & -176 & $1 \mathrm{aF}$ & $3 A$ \\
\hline Valemount & 797 & 1288 & 73 & -234 & $3 F$ & $4 \mathrm{~A}$ \\
\hline Grand Forks & 532 & 1951 & 121 & -441 & $1 \mathrm{aF}$ & $7 \mathrm{~A}$ \\
\hline Creston & 596 & 1881 & 148 & -287 & $1 \mathrm{aF}$ & $5 \mathrm{~A}$ \\
\hline Cranbrook & 939 & 1550 & 91 & -353 & $1 \mathrm{~F}$ & $6 \mathrm{~A}$ \\
\hline Old Glory Mtn. & 2348 & 421 & 22 & +186 & & 7YGF \\
\hline \multirow[t]{2}{*}{ Pemberton Meadows ${ }^{6}$} & 223 & 1801 & 150 & -281 & $1 \mathrm{aF}$ & $5 \mathrm{~A}$ \\
\hline & \multicolumn{6}{|c|}{ Fort Nelson Lowland } \\
\hline \multirow[t]{2}{*}{ Fort Nelson A. } & 375 & 1274 & 104 & -24 & & $2 G$ \\
\hline & \multicolumn{6}{|c|}{ Peace River Lowland } \\
\hline Tay Moore low ${ }^{5}$ & 460 & 1320 & $105^{4}$ & & $1^{4}$ & $2 A^{4}$ \\
\hline Dawson Creek A. ${ }^{5}$ & 655 & 1127 & 78 & -32 & & $2 G-3 G$ \\
\hline Beatton River A. & 840 & 963 & 74 & -20 & & $5 G$ \\
\hline
\end{tabular}

${ }^{1}$ From BCME (1981), Station locations indicated on Fig. 8.

${ }^{2}$ Class limitation indicated by A-aridity (negative climatic moisture balance); F-reduced freeze free period; G-insufficient heat units (growing degree days); Y-excess precipitation, May to September.

${ }^{3}$ From Wahl et al. (1987). $\quad{ }^{4}$ Estimate.

${ }^{5}$ From Lord and Green (1986), $\quad{ }^{6}$ From Beale-Kuurne (1980). 
Wetland soil Agricultural uses of wetland soils are quite limited in the northern part of this physiographic subdivision group because of adverse climate, including discontinuous permafrost and a short growing season with high frost hazard. However, though summers may be short, day length is long, precipitation low and temperature very warm so that wetlands could have an advantage for forage growth. Wetlands are mainly used for summer grazing/browse and/or stored winter forage, sometimes on improved land, for guide outfitting and some cattle/horse/buffalo ranching operations. Agriculture and wildlife capabilities are also limited because of deep snow. Recreation potential is much lower because of denser forest in both the Interior Cedar - Hemlock and Engelman Spruce - Subalpine Fir BGCZ than in the Spruce - Willow - Birch BCGZ (Pojar et al. 1983).

\subsection{Liard Plain}

Extent Wetlands of the Liard Plain occupy $762 \mathrm{~km}^{2}(5 \%)$ of this group's total land area and $1 \%$ of $\mathrm{BC}$ wetland area (Table 1). Most recorded wetlands are between 600 and $1200 \mathrm{~m}$ elevation (Fig. 2 and 6).

Wetland Region This group is covered almost entirely by the southern portion of the Continental High Boreal Wetlands. Peat plateau bogs and palsa bogs with collapsed scars are common, and veneer bogs are characteristic but fens are minor. Discontinuous permafrost occurs in peat plateaux and palsa bogs and the amount of collapsing decreases in the northern areas. The active (thawed) layer ranges from 40 to $60 \mathrm{~cm}$ in the north to 1 to $2 \mathrm{~m}$ at the southern fringe. Veneer bogs, common in the northern areas, are characterized by active layers of varying depths and discontinuous permafrost. Stream swamps are common. The average peat thickness is 2 to $3 \mathrm{~m}$ (NWWG 1986).

Climate Data from the Smith River military station at $673 \mathrm{~m}$ and Watson Lake Airport $(685 \mathrm{~m})$ in the Yukon portion of the Liard Valley indicate climate for the lower elevations of the Liard Plain which was rated CCA class 5 G (Table 9).

Wetland soil. Agriculture uses of these wetland soils are generally severely constrained by climate, except for improved pasture and limited hay production to support horses of guideoutfitters for many of the same reasons as given for the northern parts of the Northwestern Plateaux and Basin group (Pojar et al. 1983).

Many of these wetland soils provide shrub species used for browse, while adjacent shallow water bodies provide aquatic plant food, escape from insects and/or temperature regulation for moose. Agricultural crops on wetlands are generally restricted to forages due to cool, short growing seasons; although a limited area at lower elevations may allow production of hardier vegetables because of long daylight hours (British Columbia Hydro and Power Authority [BCHPA] 1980).

\subsection{Mountain}

Extent The Mountain group occupies the largest total area (526 $237 \mathrm{~km}^{2}$ ) about $56 \%$ of $\mathrm{BC}$ land area but, along with the Northwestern group, it has one of the lowest wetland densities, $1 \%$, and accounts for $8 \%\left(4211 \mathrm{~km}^{2}\right)$ of the total BC wetland (Table 1). 
A contiguous soil-CLI surveyed area in the Kootenay River drainage basin ( 82 F,G, K, portions $E$ and $L$; southeastern portion of $B C$ ) has $0.8 \%$ total wetland but about $90 \%$ is made up of Gleysols (Table 10, Fig. 2,3,9). About $73 \%$ of this wetland occurs between 300 and $900 \mathrm{~m}$ elevation (Fig. 4-7). The small area of Organics is evenly distributed over all elevation categories.

Wetland Region Wetlands of the North Coastal Mountain WR, which occupies the St. Elias Mountains in extreme northwestern $B C$, include flat bogs and horizontal fens in valleys, ribbed fens at higher elevations, and small basin bogs and fens in alpine areas (NWWG 1986). Peat thickness is usually less than $1 \mathrm{~m}$.

The Central Coastal Mountain WR occupies the Coast Mountains north of about $5200 \mathrm{~N}$ and includes flat bogs, horizontal and ribbed fens in valleys, with small basin bogs and fens in alpine areas (NWWG 1986). Marshes occur in deltaic areas along the inlets. Average peat thickness is approximately $1.5 \mathrm{~m}$.

The South Coastal Mountain WR occupies the south Coast Mountains, the Cascade Mountains and a portion of the Insular Mountains of the northern interior of Vancouver Island (NWWG 1986). These wetlands include horizontal fens and shore marshes in valleys, with ribbed fens at higher elevations. Peat thickness is usually $1 \mathrm{~m}$ or less.

The northwestern interior mountains of $B C$ and the adjacent Northwestern Plateau group are covered by the Central Interior Mountain WR (NWWG 1986). These wetlands are characterized by flat bogs, horizontal and ribbed fens with delta marshes, floodplain marshes and shallow basin marshes in valleys. Small basin bogs and basin fens occur in alpine areas. Average peat thickness is usually 2 to $3 \mathrm{~m}$.

The Central Rocky Mountain WR occupies the BC Rocky Mountains north of about 5500N (NWWG 1986). It is characterized by peat plateau bogs, palsa and veneer bogs in valleys and the lower slopes, and by small basin bogs and basin fens in alpine areas. Average peat thickness is usually 0.5 to $1.0 \mathrm{~m}$.

Table 10. Elevational distribution of wetland area in $\mathrm{km}^{2}$ and $\%$ of total map area for the southeastern (Kootenay) portion of the Mountain group ${ }^{1}$.

\begin{tabular}{|c|c|c|c|c|c|c|}
\hline \multirow{2}{*}{$\begin{array}{l}\text { Wetland } \\
\text { category }\end{array}$} & \multirow{2}{*}{$\begin{array}{l}\text { Total } \\
\text { map } \\
\text { area }\end{array}$} & \multicolumn{5}{|c|}{ Elevation category (m) } \\
\hline & & $300-600$ & $600-900$ & $900-1200$ & $>1200$ & Total \\
\hline \multirow[t]{2}{*}{ Total } & 72565 & 172 & 243 & 66 & 90 & 571 \\
\hline & 100 & 0.2 & 0.3 & $<0.1$ & $<0.1$ & 0.8 \\
\hline \multirow[t]{2}{*}{ Organic } & 72565 & 4 & 29 & 9 & 5 & 47 \\
\hline & 100 & $<0.1$ & $<0.1$ & $<0.1$ & $<0.1$ & $<0.1$ \\
\hline \multirow[t]{2}{*}{ Gleysolic } & 72565 & 168 & 214 & 57 & 85 & 524 \\
\hline & 100 & 0.1 & 0.3 & $<0.1$ & $<0.1$ & 0.7 \\
\hline
\end{tabular}

${ }^{1}$ See Fig. 8. Soil-CLI surveyed portions of 82 E,F,G,K,L,M for Mountain group (Fig. 1,8). 
The southern Rocky Mountains are covered by the South Rocky Mountain WR that includes flat bogs, horizontal fens, floodplain marshes, with shallow basin marshes occurring in valleys, and small basin fens and basin bogs occurring in alpine areas (NWWG 1986). Peat thickness is usually less than $1 \mathrm{~m}$.

The Columbia Mountains in the southeast of $\mathrm{BC}$ are covered by the South Interior Mountain WR (NWWG 1986). These include flat bogs, basin bogs and shallow basin marshes. Small basin fens and basin bogs occur in alpine areas. Peat thickness usually averages 1 to $2 \mathrm{~m}$. A narrow band of Intermountain Prairie wetlands occurs in the upper valleys of the Columbia and Kootenay Rivers.

Glaciers occur as discontinuous units in the higher elevations of all the mountain subdivisions but concentrate, particularly in the South Rocky, South Interior, North Coastal, north part of Central Coastal and South Coastal (only in Coast Mountains) Mountain WR (NWWG 1986). They contain a tremendous reserve of stored water, part of which melts each spring and summer to provide replenishing water for many wetlands, ground water and rivers at lower elevations. These glaciers, wetlands, ground water and rivers are important sources of the year-long water supply in these areas of $\mathrm{BC}$.

Climate Climate generally becomes cooler and moister with increasing elevation and increasing westerly longitude and northerly latitude, so that GDD and FFP decrease while CMB increases (becomes moister) (Table 9). Aridity (negative CMB) increases on the lee side (east) of the mountains.

Low elevations of the major southern valleys rate CCA class 1 (irrigated) where tree fruits and many horticultural crops can be grown but CCA becomes progressively poorer toward the north; compare Cranbrook or Grand Forks to Dawson Creek Airport, New Hazelton or Smith River (Table 9). Severe aridity in southern $\mathrm{BC}$ gives the wetland soils a distinct advantage where water control structures are feasible to provide sub- or flood-irrigation. However, the area of wetlands is very limited.

Old Glory Mountain station at $2348 \mathrm{~m}$, the only long term BC station located at such a high altitude, reflects the extreme climate and extremely poor CCA rating for high mountain locations due to minimal GDD, FFP and excessive moisture. A map depicting CCA was prepared for the east Kootenay area by Marshall (1969; S of 5115N, E of $11630 \mathrm{~W})$.

In the Tofino-Uclulet Lowland surveyed area (145 km²; Valentine 1971a, portion $102 \mathrm{~F} / \mathrm{SW}$ ) on the west coast of Vancouver Island, little agriculture is practised due to excess precipitation and low EGDD (similar to Estevan Point, Table 5), as compared to an east coast site such as Duncan.

Wetland soil Discussion of the soils of this group follow the approximate order of south to north coastal, then north to south for the interior.

After dyking, the project area of the Pemberton Valley (Beale-Kuurne 1980, portion $92 \mathrm{~J} / 6$, 9-11) rated improved CCA class 1aF (Pemberton Meadows, Table 9). Included in this report is a map showing CCA along with an extensive legend of suitable crops that can be grown. Over the remainder of the surveyed area, improved classes ranged between $1 \mathrm{aF}$ and $2 \mathrm{~F}$ with GDD and FFP limiting production of sensitive crops. 
Wetland sites of the Stikine River Valley floodplain area were rated CCA class 2 (improved) or class 7 (unimproved) for agricultural soil capability. Flooding and high water tables would probably make water control management practices economically impractical under the current economic conditions (Epp and Fenger 1978, portion $104 \mathrm{G} / \mathrm{NW}$ ). In the east central Rocky Mountains and Foothills (Vold et al. 1977, 93 I/9-16, portions $93 \mathrm{~J} / 9$ and $93 \mathrm{P} / 1-12$ ), low to nil CCA is due to excess moisture, flooding and other adverse climatic features of these wetlands. Low to moderate capability ratings for ungulates result mainly from the low natural forage supply.

In the upper part of the Fraser Valley in the Rocky Mountain Trench between Valemount and Prince George, a Gleysol rates CCA class 3 to 4 . Heavy forest cover, poor drainage and local climate limits the agricultural development but, when drained, this soil will produce good forage yields (Hortie et al. 1970, portions of $83 \mathrm{D} / 11,13,14 ; 83 \mathrm{E} / 4 ; 93 \mathrm{AV} 16 ; 93 \mathrm{H} / 8-11,13,14 ; 93$ I/4; 93 $\mathrm{G} / 16 ; 93 \mathrm{~J} / 1,8)$.

If drained and developed, wetland soils (CCA rating class 6, 7 and minor inclusions of 5, all unimproved) on the Columbia, Kootenay and Lower Elk River flood plains (Jungen and Runka 1969 ; S of $5115 \mathrm{~N}, \mathrm{E}$ of $11630 \mathrm{~W}$ ) could produce agricultural crops if land use was restricted to crops tolerant of local climatic conditions: grass, clover, oats, potatoes and some other coolseason vegetables. However, care should be taken in the choice of crops, as the moderate to high lime content of the parent material derived from limestones of the adjacent Rocky Mountains, can have adverse effects on crop production. Some soils adjacent to the Columbia River are used for limited grazing wherever river levels are low enough and for production of sedge hay on some of the higher wet areas. The alpine wetland soils are unsuitable for cultivation and use for grazing by domestic animals is limited, although native forage production can be quite good. Kelley and Sprout (1956) and Kelley and Holland (1961) give detailed discussion on the agricultural use, including irrigation/drainage for the soil map units of the Upper Columbia River Valley and the Upper Kootenay and Elk River Valleys, respectively.

Marshall (1969; S of 5115 N, E of 11630W) and Jungen and Runka (1969) gave extensive discussions on climatic and soil agricultural capabilities for the East Kootenay. The latter related the agricultural capabilities to those for other uses, including wildlife. The better CCA (class 1 to 3) areas occur mainly in the bottoms of the major valleys where the wetlands occur. Adverse climate nearly precludes CCA class 1 in most areas, and especially on wetlands, mainly due to limited FFP (Tables 9, see Cranbrook). Organic soils (class 6 or 7 unimproved) occupy only $0.04 \%$ of the East Kootenay survey area (Table 10, compare Figs. 2 to 3). Lacelle (1990; S of $5108 \mathrm{~N}, \mathrm{E}$ of $11600 \mathrm{~N}$ ) presented a tabular outline of CCA and soil capability for agriculture for each soil association that was described and added further discussion on their capabilities.

Organics and Gleysols at low elevations of Seymour Arm map area (Kowall 1980, 82M) are capable of producing perennial forage crops but at higher elevations only livestock grazing of native forage species is feasible (CCA class 6).

Improved Gleysols and Organics in the main valley bottoms of the Lardeau map area (Wittneben $1980,82 \mathrm{~K}$ ) rate similar to those of other Kootenay stations, CCA class 1 aF (Table 9 , Fig. 8).

The dyked and drained wetlands of the Creston Flats (Wittneben and Sprout 1971, 82 F/SE) rate CCA class $1 \mathrm{aF}$ (Table 9 , Creston). Phosphate and potash fertilizers are required to produce top alfalfa yields on the better drained members of these soils (Neville Gough, personal communication). 
The main agricultural use of wetlands in areas above the alpine/forest boundary in the southern interior of BC, such as in the Princeton map area, is for summer grazing of domestic livestock on lush sedge and forb vegetation that thrive, along with shrubs. Adjacent well-drained soils in the driest parts of this southern interior BC area are not capable of producing much useable forage in these harsh, dry climates (Green and Lord 1979, 92 H/SE; van Ryswyk 1969, portion $92 \mathrm{H} / 1$ ).

\subsection{Fort Nelson Lowland}

Extent Wetlands of the Fort Nelson Lowland cover $27852 \mathrm{~km}^{2}$, or $55 \%$ of the group's total land area and $52 \%$ of BC wetland area (Table 1). All of the wetlands occurs below $900 \mathrm{~m}$ and most between 300 and $600 \mathrm{~m}$ with a minor amount below $300 \mathrm{~m}$ (Table 11). In the soil surveyed portion of this group, the area of Organic wetland dominates over that of Gleysolic wetland by up to eight-fold above $300 \mathrm{~m}$ but neither Organic nor Gleysolic wetlands were recorded below $300 \mathrm{~m}$ (Table 11, Figures 2-7, 9).

Table 11. Elevational distribution of wetland area in $\mathrm{km}^{2}$ and $\%$ of total map area for the Fort Nelson Lowland group'.

\begin{tabular}{lrrrrr}
\hline \hline \multirow{2}{*}{$\begin{array}{l}\text { Wetland } \\
\text { category }\end{array}$} & Total & \multicolumn{5}{c}{ Elevation category $(\mathrm{m})$} \\
\cline { 3 - 6 } & marea & $0-300$ & $300-600$ & $600-900$ & Total \\
\hline Total & 50290 & 4 & 23454 & 4393 & 27851 \\
& 100 & $<0.1$ & 46.6 & 8.7 & 55.4 \\
Organic & 9587 & 0 & 3675 & 211 & 3886 \\
& 100 & 0.0 & 38.3 & 2.2 & 40.5 \\
Gleysolic & 9587 & 0 & 480 & 23 & 503 \\
& 100 & 0.0 & 5.0 & 0.2 & 5.2 \\
\hline
\end{tabular}

${ }^{1}$ See Fig. 8. Organic and Gleysolic wetland areas derived from soil-CLI surveyed map sheets (Fig. 1).

Wetland Region Most of the area of this group (NWWG 1986) is covered by the southern portion of the Continental High Boreal WR but a part of the most northeastern portion is covered by a southern outlier of the Low Subarctic WR. The latter is characterized by peat plateau bogs, palsa bogs, ribbed and horizontal fens with discontinuous permafrost under the bogs but not under the fens. The thickness of the active (thawed) layer reaches a maximum of $60 \mathrm{~cm}$. Average peat thickness is $2-3 \mathrm{~m}$.

Climate Climate of the Fort Nelson area is characterized by short cool summers, severe winters, a wide annual range of temperature and a modest total annual precipitation, most of which falls in the summer (Valentine 1971b, $94 \mathrm{~J} / \mathrm{NE}$ ). He estimated that between the elevation range of 300 and $760 \mathrm{~m}$, the GDD would range between 1350 and $723^{\circ} \mathrm{C}$ days and the FFP would range between 100 and 17 days. Drought is not usually a problem because of the near zero CMB (-24 mm), except possibly on sandy soils. 
The climate for Fort Nelson station is indicative for the lower elevations of the eastern part of this group (CCA class 2G, Table 9). The extra long hours of summer daylight in the northern latitudes have been perceived to promote better plant growth than at lower latitudes for the same GDD but this phenomenon has been difficult to evaluate and is not currently accountable in the CCA ratings. Cheesman and Davis (1982) however state that, "consideration of the day length factor equates some elements of the (Peace River) Valley's agricultural potential to many locations in the Lower Fraser Valley and southeastern Vancouver Island. The ability to grow corn in select locations in the Peace River Valley lends credence to this conclusion." They have developed a day length factor related to latitude (expressed as a fraction of the day length at $4000 \mathrm{~N}$ ) to arrive at a heliothermic index for several BC locations.

Meidinger and Lewis (1983) stated that although there was a lack of climate stations in this northern area, it seemed that the climate was warmer in the summer (May through September) but likely cooler in the winter (October through April) and that precipitation was lower in all seasons in the Northern subzone than in the Montane BGC subzone on the higher elevations of the Alberta Plateau to the west.

Wetland soil Agricultural uses of wetland soils in this group are quite limited for many of the same reasons as for the Northwestern Plateaux and Basin and Liard Plain groups. However, part of the area of this group has a climate favorable for cultivated crops. Organic soils are very acid and difficult to drain because they cover such extensive areas on flat terrain underlain by slowly permeable fine textured materials. Only a limited area of Organic and Gleysolic wetlands occur on undulating terrain that may be drainable. Coldness, due to wetness, retards early season plant growth. For these reasons, the most suitable agricultural use for these wetland soils was considered to be for growing adapted native forage species (Valentine 1971b).

Maynard (1988) indicated that peat bogs in northeastern BC contain acceptable horticultural and fuel quality peat. Although these bogs are extensive, climate and remoteness limits the possibility for extraction, as does the permafrost north of the southern limit of discontinuous permafrost (Fig. 8).

\subsection{Peace River Lowland}

Extent Wetlands of the Peace River Lowlands cover $9582 \mathrm{~km}^{2}$ accounting for $18 \%$ of this group's total land area and for $18 \%$ of BC wetland area (Table 12). Most of this group's wetland (17\%) occurs between 600 and $900 \mathrm{~m}$ elevation but small amounts occur at other elevations between 300 and $1200 \mathrm{~m}$ (Table 12). In the soil-CLI surveyed area between 600 and $900 \mathrm{~m}$, Gleysols dominate, consisting of $14 \%$ of the area compared to $11 \%$ for Organics. Small areas of wetlands occur up to $1200 \mathrm{~m}$ (Fig. 2-7).

Wetland Region A portion of the northern part of this group is covered by the Continental High Boreal WR (NNWG 1986). However, the area of this group south of about $5700 \mathrm{~N}$ is covered by the Continental Mid-boreal WR. Here flat and basin bogs are common often in association with horizontal and ribbed fens, marshes occur along gently sloping lakeshores. Average peat thickness in wetlands is about $4 \mathrm{~m}$. Permafrost is absent.

Climate Farstad et al. (1965, within $5530 \mathrm{~N}$ to $5715 \mathrm{~N}$ and $12000 \mathrm{~W}$ to $12200 \mathrm{~W}$ ) reported the climate was a moderate continental type with moderately warm summers and relatively cold winters. They listed data for several stations where the average FFP ranged between 20 and 123 
days but the duration of growing period $\left(>6.1^{\circ} \mathrm{C}\right.$ mean temp.) was remarkably constant, 151 to 165 days. Selected stations (Table 9 ) indicate a decrease of GDD and FFP with increasing elevation and a near zero CMB. A CCA class 1 (improved) rating is given for the Peace River valley at Tay Moore low station, $460 \mathrm{~m}$ elevation, but at Mt. Lemoray, $680 \mathrm{~m}$, the rating was CCA class $3 \mathrm{G}$ (Lord and Green 1986, $93 \mathrm{P} / \mathrm{N}, 94 \mathrm{~A} / \mathrm{S}$ ). They presented a map depicting CCA ratings for agriculture.

Table 12. Elevational distribution of wetland area in $\mathrm{km}^{2}$ and $\%$ of total map area for the Peace River Lowland group".

\begin{tabular}{|c|c|c|c|c|c|c|}
\hline \multirow{2}{*}{$\begin{array}{l}\text { Wetland } \\
\text { category }\end{array}$} & \multirow{2}{*}{$\begin{array}{l}\text { Total } \\
\text { map } \\
\text { area }\end{array}$} & \multicolumn{5}{|c|}{ Elevation category $(\mathrm{m})$} \\
\hline & & $300-600$ & $600-900$ & $900-1200$ & $1200-1500$ & Total \\
\hline \multirow[t]{2}{*}{ Total } & 52450 & 267 & 8740 & 569 & 5 & 9581 \\
\hline & 100 & 0.5 & 16.7 & 1.1 & $<0.1$ & 18.3 \\
\hline \multirow[t]{2}{*}{ Organic } & 34258 & 100 & 3713 & 114 & 0 & 3927 \\
\hline & 100 & 0.3 & 10.8 & 0.3 & 0.0 & 11.4 \\
\hline \multirow[t]{2}{*}{ Gleysolic } & 34258 & 86 & 4788 & 399 & 0 & 5273 \\
\hline & 100 & 0.3 & 14.0 & 1.2 & 0.0 & 15.5 \\
\hline
\end{tabular}

'See Fig. 8. Organic and Gleysolic wetland areas derived from soil-CLI surveyed map sheets (Fig. 1).

Agriculture Canada, Land Resource Research Centre, Pedology Unit, Vancouver is currently revising the ratings of soil capability for agriculture for soil map polygons of the Peace River map sheets based on a revised climatic capability for agriculture provided by the BCME, Air Management Branch. A new capability rating system (1988) based on soil and climate, which improved upon the 1974 system, has been developed to an interim stage and applied to at least one map area (93 P/NW Chetwynd) by the Centre for Land and Biological Resources Research, Research Branch, Agriculture Canada, Vancouver (Corinne Selby, personal communication). The new system includes a computer file designed to obtain information from numbered map polygons, based on the Fort St. John - Dawson Creek soils report (Lord and Green 1986) to integrate information on topography, depth to bedrock, rock outcrop and drainage factors thus creating an improved soil rating system.

Wetland Soil The land capability for agriculture of the Organics may be low due to coldness and drainage difficulty and, especially on the sphagnic phases, due to low fertility associated with strong acidity (Lord and Green 1986). The Gleysols that can be drained would rate class 3 to 4 (improved), useful mainly for forage crops only because a frost hazard is ever present. The Humic Gleysols and their peaty phases likely have higher fertility than Luvic Gleysols. The organic matter of these Humic Gleysols could be expected to decompose quite slowly if water table levels were maintained appropriately for adapted forage crops. The areas of CCA class 1 and 2 (irrigated) in the lower Pine and Peace River Valleys contain virtually no wetland. The wetlands, however, have moderate to high capability for recreation, hunting and for wildlife, especially as winter habitat. 


\section{SUPPLEMENTARY WETLAND SOIL INFORMATION}

\subsection{Introduction}

The following detailed discussions of wetland soil information, gleaned mainly from soil survey reports and maps are included here, by physiographic subdivision groups, for those readers with further academic interest in specific topics.

\subsection{Hecate Depression}

Mesisols and Humisols are typically associated with the bog wetland class, forested or woodland type, in the north Pacific Oceanic WR but Gleysols, Humic Gleysols and Folisols with thick (10 to $55 \mathrm{~cm}$ ) surface organic horizons also occur according to Banner et al. (1986). They further described open and shallow minerotrophic blanket bog types; the latter occur with complexes of Gleysols, Humic Gleysols, Gleyed Podzols, Folisols and shallow Humisols and Mesisols covered by shore pine, yellow cedar and western red cedar, less than $2 \mathrm{~m}$ tall, as well as ombrotrophic bog vegetation types occupying Mesisols and Fibrisols. The forested and woodland bog types cover virtually all ranges of topographic slope classes and occur as organic blankets and veneer over bedrock, and morainal, colluvial or fluvial deposits.

Fen types were described by Banner et al. (1986), usually with Mesisols or Humisols and in some places Humic Regosols. The fens are most common along drainage systems of the eastern lowlands of the Queen Charlotte Islands. Marsh and swamp wetland classes are localized and do not dominate the landscape. Gleysols, Humic Gleysols or Mesisols dominate in the swamp class.

Moon and Selby (1988, portion $\left.92 \mathrm{~L} / \mathrm{SW}, 60 \mathrm{~km}^{2}\right)$ described one map unit $\left(6 \mathrm{~km}^{2}, 10 \%\right)$ that contains inclusions of peaty phase Gleysols (probably Folisol ACECSS 1987) and an extremely acid Organic soil (probably Terric, ACECSS 1987) with a humic horizon overlain by a fibric horizon. They considered the well drained organic seposit to have Fibri-humimor and Humimor humus forms. These wetland soils are found at elevations above $600 \mathrm{~m}$ in the Power River watershed on the northeast coast of Vancouver Island.

\subsection{Georgia Depression}

The first soil survey for this area was published by Kelley and Spilsbury (1939, portions of $92 \mathrm{G} / 1-3$ and $\mathrm{H} / 4,5$ ) covering the Lower Fraser Valley (i.e. Fraser Lowland portion of Georgia Depression, Holland 1976) from Agassiz to Richmond. Luttmerding (1980a,b Vol. 1 and 2, portion $92 \mathrm{G} / \mathrm{S}$ ) prepared 'Soils of the Langley-Vancouver Map Area' which collated, summarized, and presented in a uniform manner, all the information in previous published and interim reports. The area lies between $4900 \mathrm{~N}$ and $4930 \mathrm{~N}$ and between $12200 \mathrm{~W}$ (Chilliwack) and the Strait of Georgia. Soil maps are presented at 1:25 000 scale for the southern portion (Lower Fraser Valley, Vol. 1) and 1:50 000 scale for the northern portion (Sunshine Coast and Southern Coast Mountains, Vol. 2) for all except urbanized and industrialized areas. Detailed descriptions of soils and their general suitability or limitations for a variety of uses are given in Luttmerding (1981a, Vol. 3). Limitations of agriculture soil management groups are discussed and agriculture capability maps,including drained and/or irrigated ratings, are presented (Luttmerding 1984, Vol. 5). Detailed soil profile descriptions, chemical and physical analysis data are given (Luttmerding 1981b, Vol. 6). 
Soils of the Langley-Vancouver map area include a wide range of Orthic and Peaty Gleysols, and Humic Gleysols; Organic Humisols, Mesisols and Fibrisols (Table 13). The Gleysols occur mainly on silty and clayey fluvial, glaciomarine, marine or lacustrine deposits and the Organics on organic deposits 40 to greater than $160 \mathrm{~cm}$ deep (Table 14).

The Langley-Vancouver soil-surveyed map area covers $4020 \mathrm{~km}^{2}, 1890 \mathrm{~km}^{2}$ in the Lower Fraser River Valley portion and $2130 \mathrm{~km}^{2}$ on the "Sunshine Coast", generally north of Vancouver and in the Coast Mountains (Table 13; Luttmerding 1980a and 1980b; Vols. 1 and 2, respectively). Many of the wetlands occur in the Lower Fraser River Valley portion below $300 \mathrm{~m}$ elevation. Total wetland, including simple (pure) and compound (complex) map units, covers 685 $\mathrm{km}^{2}(17 \%$ of the total surveyed area). About $13 \%$ is occupied by Gleysols, $4 \%$ by Organics (excluding Folisols). Saline phases of the Gleysols, developed due to seepage of ocean water, account for $73 \mathrm{~km}^{2}(2 \%)$; peaty phases account for $70 \mathrm{~km}^{2}(2 \%)$; and a peaty, saline phase for $16 \mathrm{~km}^{2}(0.4 \%)$ (Luttmerding 1981). Soils containing well humified organic material in their surface horizons (Humic Luvic Gleysol, Humic Gleysol, peaty phases of Gleysols, and Humisols) account for $416 \mathrm{~km}^{2}(10 \%)$, over half of the area's wetlands.

Over one-half ( $9 \%$ of the total surveyed area) of the wetlands occur on fluvial materials deposited by rivers and streams (Table 14). About $10 \%$ are materials of marine origin. The subsoils of certain of these soils contain sulfurous compounds that produce high acidity upon weathering (Lowe and Bustin 1985). Lacustrine (lake deposited) materials account for $59 \mathrm{~km}^{2}$ $(2 \%)$ and silty aeolian (wind deposited) materials for $13 \mathrm{~km}^{2}(0.3 \%)$ of the surveyed area.

Soils of the eastern part of the Fraser Lowland were described in two preliminary reports covering the Chilliwack and Agassiz areas. Wetland soil forming materials include those on uplands derived from glacial till and outwash, colluvial, stream, slide or aeolian deposits, and those on lowlands derived from Fraser floodplain, swamp, stream, slide, or organic deposits.

The Chilliwack area, $362 \mathrm{~km}^{2}$, contained Orthic Meadow and Orthic Dark Gray Gleysol (both probably Orthic Humic Gleysol, ACECSS 1987), $44 \mathrm{~km}^{2}(12 \%)$ with Orthic (11\%) dominant, Orthic and Rego (normal and peaty phases); Gleysols $35 \mathrm{~km}^{2}(10 \%)$ with Orthic $(8 \%)$ dominant, and Muck (probably Terric and Typic Humisols, ACECSS 1987) $7.3 \mathrm{~km}^{2}$ (2\%) (Comar et al. 1962 , portion $92 \mathrm{G} / 1, \mathrm{H} / 4 ; 1: 24000)$. Agassiz area, $282 \mathrm{~km}^{2}$, contained Orthic and Rego Humic Gleysols, $12 \mathrm{~km}^{2}$ (4.1\%) with Rego (3.9\%) dominant, Rego Gleysol $6.7 \mathrm{~km}^{2}(2.4 \%)$, and Muck (probably Terric and typic Humisols, ACECSS 1987), $3.5 \mathrm{~km}^{2}(1.2 \%)$ (Luttmerding and Sprout 1967, portion $92 \mathrm{H} / 4,5$ and $6 ; 1: 24$ 000).

Soils of southeastern Vancouver Island and Gulf Islands (Day et al. 1959, portion 92 B/W, C/9, F/SE and NW; 1:63 360) include Gleysols, and well and poorly decomposed Organics that would likely be equivalent to Humisols and Fibrisols, respectively (ACECSS 1987). A recent report by Jungen (1985, between $12300 \mathrm{~W}$ and $12600 \mathrm{~W}$ ) gave further details for southern Vancouver Island on climate, vegetation and soil associations; including six Terric Mesisols and one Terric Humisol, all of which were strongly to very strongly acid, and six Humic Gleysols, most of which were medium to slightly acid. These associations were differentiated by BGCZ or subzone and surficial geologic deposit as well as by soil profile characteristics (soil great group, subgroup) and subdivided by component groups, each with its defined range of variability. Chatterton et al. (1980, W of 12600W, 1:50 000) gave descriptions of soils of northern Vancouver Island, differentiated in a similar manner to that of Jungen et al. (1985) and included Terric Mesisol, Terric Humisol and Gleysol. 
Table 13. Summary of wetland area $\left(\mathrm{km}^{2}: \%\right.$ of total map area, i.e. $\left.4020 \mathrm{~km}^{2}=100 \%\right)$ occupied by classified soils in the Langley-Vancouver map area'.

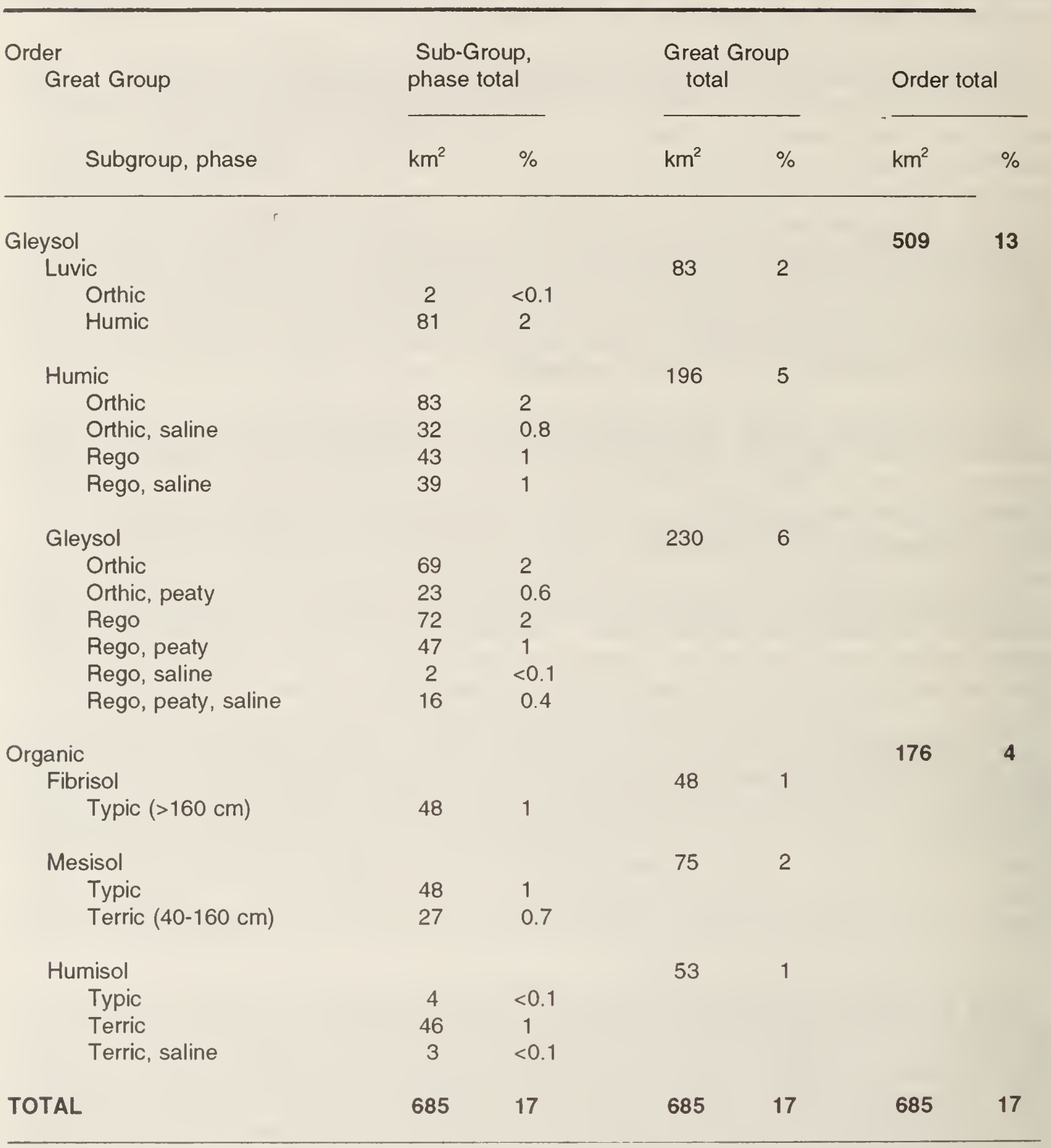

'Luttmerding 1981a, b. 
Table 14. Summary of wetland area $\left(\mathrm{km}^{2}: \%\right.$ of total map area, i.e. $\left.4020 \mathrm{~km}^{2}=100 \%\right)$ by surficial deposits (materials) in the Langley-Vancouver map area'.

\begin{tabular}{|c|c|c|c|c|c|c|}
\hline \multirow{2}{*}{$\begin{array}{l}\text { Material } \\
\text { Source } \\
\text { Texture/depth }\end{array}$} & \multicolumn{2}{|c|}{$\begin{array}{l}\text { Texture/depth } \\
\text { total }\end{array}$} & \multicolumn{2}{|c|}{ Source total } & \multicolumn{2}{|c|}{$\begin{array}{l}\text { Material } \\
\text { total }\end{array}$} \\
\hline & $\mathrm{km}^{2}$ & $\%$ & $\mathrm{~km}^{2}$ & $\%$ & $\mathrm{~km}^{2}$ & $\%$ \\
\hline Fluvial & & & & & 338 & 9 \\
\hline Deltaic & & & 145 & 4 & & \\
\hline sandy, silty/clayey & 145 & 0.8 & & & & \\
\hline Floodplain & & & 155 & 4 & & \\
\hline silty/clayey & 155 & 4 & & & & \\
\hline Local stream & & & 34 & 1 & & \\
\hline sandy & 8 & 0.2 & & & & \\
\hline silty/clayey & 26 & 0.7 & & & & \\
\hline Fan & & & 4 & $<0.1$ & & \\
\hline sandy/gravelly & 4 & $<0.1$ & & & & \\
\hline Glaciomarine & & & & & 44 & 1 \\
\hline silty/clayey & 44 & 1 & 44 & 1 & & \\
\hline Marine & & & 55 & 1 & 55 & 1 \\
\hline sandy/gravelly & 20 & 0.5 & & & & \\
\hline clayey & 35 & 0.9 & & & & \\
\hline Lacustrine & & & 59 & 2 & 59 & 2 \\
\hline sandy & 27 & 0.7 & & & & \\
\hline silty/clayey & 32 & 0.8 & & & & \\
\hline Eolian & & & 13 & 0.3 & 13 & 0.3 \\
\hline silty & 13 & 0.3 & & & & \\
\hline Organic & & & 176 & 4 & 176 & 4 \\
\hline $40-160 \mathrm{~cm}$ & 76 & 2 & & & & \\
\hline$>160 \mathrm{~cm}$ & 100 & 2 & & & & \\
\hline TOTAL & 685 & 17 & 685 & 17 & 685 & 17 \\
\hline
\end{tabular}

${ }^{1}$ Luttmerding 1981a, b. 
Jungen et al. (1985, portion $92 \mathrm{~B} / \mathrm{NW}, \mathrm{F} / 1$ and $8, \mathrm{G} / 4$ and $5 ; 1: 20000$ ) in a detailed survey reported on soils of an area of southeast Vancouver Island lying on the transition zone between Brunisolic and well drained Podsolic upland soils and within the Coastal Grand Fir - Western Red Cedar (presumably subzone) of the Coastal Douglas fir BGCZ. The western boundary of this area coincides with the transition to the Coastal Western Hemlock BGCZ. Each named soil was subdivided according to variant or phase. They coordinated these more narrowly-defined soil names with those first published by Day et al. (1959) for their surveyed area covering $765 \mathrm{~km}^{2}$. It included Orthic Humic Gleysol $8 \mathrm{~km}^{2}(1.1 \%)$, Humic Luvic Gleysol $28 \mathrm{~km}^{2}(3.7 \%)$, Rego Humic Gleysol $19 \mathrm{~km}^{2}(2.5 \%)$, typic Mesisol $5 \mathrm{~km}^{2}(0.7 \%)$ and Typic Humisol $14 \mathrm{~km}^{2}(1.9 \%)$. The Gleysols occurred on marine, fluvial or morainal surficial geologic deposits.

The Gulf Islands of southwestern BC occupy a total area of $521 \mathrm{~km}^{2} ; 3.5 \mathrm{~km}^{2}(0.7 \%)$ contain Organic soils and $38 \mathrm{~km}^{2}(7 \%)$ Gleysols (van Vliet et al. 1987, 1991; Kenney et al. 1988, 1990; Green et al. 1989; portion $92 \mathrm{~B} / \mathrm{NW}, 92 \mathrm{G} / 4 ; 1: 20000$ ). Typic Humisols are dominant in the one Organic map unit with inclusions of mainly Terric Humisols, some Limno and Terric Mesic Humisols, and some Limno and Terric Mesisols. Diatomaceous earth, sedimentary peat or shallow organic phases occupy certain map polygons along with Gleysols in a few instances. A Humic Luvic Gleysol $\left(11 \mathrm{~km}^{2}, 2 \%\right)$ and four Orthic Humic Gleysols $\left(27 \mathrm{~km}^{2}, 5 \%\right)$ with inclusions of Orthic Gleysols and/or Rego humic Gleysols occur on a variety of geologic materials. Phases (deep, imperfectly drained, shallow-lithic, gravelly, sandy, loam, silt loam, strongly mottled and saline) and a sombric variant further characterize certain of the dominantly Gleysolic soil map polygons. The authors described map units (one or more named soils) and defined the expected ranges of variability within each one.

\subsection{Interior Plateau, North}

Soil reports of Gough (1988, 92 P/E), Valentine and Shori (1980, 92 P/W) and Valentine et al. $(1987,92$ O) cover the southern part of the Chilcotin-Cariboo. The combined total land area is $30842 \mathrm{~km}^{2}$ containing Gleysols $\left(222 \mathrm{~km}^{2}, 0.72 \%\right)$ and Organics $\left(218 \mathrm{~km}^{2}, 0.71 \%\right)$. They described a Carbonated Rego Humic Gleysol occurring over a wide range of elevations. A Rego Humic Gleysol occurs in the Interior Douglas Fir BGCZ below $500 \mathrm{~m}$ (Gough 1988, 92 P/E) and another is widespread up to $1500 \mathrm{~m}$ (Valentine et al. 1987). Two Terric and one Typic Mesisols account for a large proportion of the Organic soils through the Interior Douglas Fir and into the Englemann Spruce - Subalpine Fir BGCZ. These soils are generally neutral to slightly acid due partly to the arid climate and partly to basic parent materials. Further north at the boundary of the Central and Chilcotin - Cariboo portions Lord and Walmsley (1988a 93 B/NW, G/SW 7454 $\mathrm{km}^{2}$ ) indicated $26 \mathrm{~km}^{2}(0.004 \%)$ of carbonated Rego Humic Gleysols and $104 \mathrm{~km}^{2}(1.4 \%)$ Typic Mesisols covering that map area.

The vegetation of these wetlands consists of few trees, willows (Salix spp.), bog birch (Betula glandulosa) and other shrubs, sedges (Carex spp.) and grasses. Specific vegetation communities and their relation to wetland ecosystems have been described by Moon and Selby (1983), Steen and Roberts (1988), and Runka and Lewis (1981) who evaluated wildlife, waterfowl and domestic livestock uses for certain ecosystems.

A Mesic Fibrisol occurs above $1200 \mathrm{~m}$ in the southeast part of the Chilcotin-Cariboo (Gough 1988). Luvic and Humic Gleysols and Terric Humisols occur in the northeastern part of the Chilcotin-Cariboo and southeastern part of the Central Interior on the Fraser Plateau and Quesnel Highland below about 1200 m (Lord 1984, 93 AW; Lord and Green 1985, 93 H/W). Very acidic Terric Fibric Mesisols and strongly acidic Typic Mesisols also occur on the Quesnel Highlands whereas acidic ones occur on the Fraser Plateau. Vegetation includes sparse tree cover of black 
spruce (Picea mariana), lodgepole pine (Pinus contorta), and of labrador tea (Ledum groenlandicum), ericaceous shrubs, herbs, sedges and mosses. These soils occur in the Engelmann Spruce - Subalpine Fir BGCZ and extend into the Interior Cedar - Hemlock BGCZ of the interior wet belt on the western edge of the Columbia Mountains. The combined area of Horsefly (Lord and Green 1984) and Barkerville (lord 1985) map area is $14055 \mathrm{~km}^{2}$ and contains $32 \mathrm{~km}^{2}(0.2 \%)$ Gleysols and $270 \mathrm{~km}^{2}(1.9 \%)$ Organaics of which $0.6 \%$ are Humisols and the remainder Mesisols.

The Williams Lake - Alexis Creek soil-surveyed map area $\left(7592 \mathrm{~km}^{2}\right)$ occurs in an elevational range of 450 to $1665 \mathrm{~m}$ (Lord and Walmsley 1988b, $93 \mathrm{~B} / \mathrm{S}$ ). It contains pure and complex map units of Rego Humic Gleysol, carbonated phase $\left(133 \mathrm{~km}^{2}, 2 \%\right)$ generally associated with Dystric Brunisols; of Fibrisols and Mesisols with inclusions of Humic Mesisols, terric subgroups and Gleysols $\left(288 \mathrm{~km}^{2}, 3 \%\right)$ generally associated with Orthic Gray Luvisols; and of Terric Mesisols with inclusions of Typic subgroups and Gleysols $\left(144 \mathrm{~km}^{2}, 2 \%\right)$. The Fibrisols and Mesisols are generally found on bog and fen peat landforms, respectively. Bog vegetation consists of black spruce, lodgepole pine, ericaceous shrubs and mosses. The fens are nonforested but covered with sedges, mosses and grasses.

The soil survey (Leskiw and Farstad 1973, portion $92 \mathrm{P} / 14 \mathrm{E}, 15 \mathrm{~W}$ ) of the Canim Lake Indian Reserve No. ? $\left(19 \mathrm{~km}^{2}\right)$ indicated that soil units dominated by Gleyed Regosols $\left(3 \mathrm{~km}^{2}, 17 \%\right)$ and associated with Carbonated Rego Humic Gleysols, and those dominated by Terric Humisols $(0.2$ $\mathrm{km}^{2}, 1 \%$ ) occur along the valley bottom of Bridge Creek leading into Canim Lake, just below 800 $\mathrm{m}$ elevation.

The Anahim [Anahim's Flat 1] Indian Reserve covers $30 \mathrm{~km}^{2}, 0.75 \%$ of which consists of poorly drained, calcareous silty and clayey deposits occurring in nearly level to depressional areas (Leskiw et al. 1973b, portion $93 \mathrm{~B} / 3 \mathrm{SE}$ ). Soils have a dark gray calcareous humified silt loam surface layer overlying a brownish gray calcareous, silt loam or silty clay loam subsoil (probably Humic Gleysol, calcareous phase, ACECSS 1987).

The Williams Lake 1 [Sugar Cane] Indian Reserve (1700 ha) does not have any soils classified as Organic or Gleysolic but Leskiw et al. (1973a, portion 93 A/4, B/1; 1:14 480) report $3-2 \mathrm{~km}^{2}(19 \%)$ of Carbonated Gleyed Regosols on the bottom lands adjacent to the junction of the San Jose River with Williams Lake. The surface texture of these soils ranged from silty clay loam to sandy loam in the upper part of the bottom lands.

The earliest soil reports covering the south central part of the central interior portion were prepared by Kelley and Farstad (1946, 93G/10,15, J/2,7) and Farstad and Laird (1954). They referred to wetland soils described as muck, peaty meadow, peat bog, muskeg and Dark Grey Gleysolic.

Lord and Mackintosh (1982, $93 \mathrm{~B} / \mathrm{NE}$ and G/SE, $1202 \mathrm{~km}^{2}$ ) reported on soils in the vicinity of Quesnel with over $2 \%$ associated wetland soils. Fibric Mesisols occur on bog wetlands east of the Fraser River in the wetter portions of the Sub-boreal Spruce BGCZ in the Fraser Plateau and Basin, generally below $1200 \mathrm{~m}$, whereas Humic and Terric Mesisols are found on fen wetlands in the drier portions of the zone. Gleysols are associated with these Organics and extend below $600 \mathrm{~m}$. The bog land forms are commonly covered with sphagnum mosses, scattered black spruce and lodgepole pine. Dawson (1989 $93 \mathrm{G} / \mathrm{N}, \mathrm{J} / \mathrm{S}, 14645 \mathrm{~km}^{2}$ ) indicated complexed Organics (410 km², $2.8 \%$ ) and Gleysolic $\left(220 \mathrm{~km}^{2}, 1.5 \%\right)$ soils with Regosols $\left(278 \mathrm{~km}^{2}, 1.9 \%\right)$ complexed with Gleysols for the Prince George - McLeod Lake map area. 
Forested Humic Gleysols occur in the Central Interior portion south of Fort St. James (Cotic 1974, $93 \mathrm{~K} / \mathrm{S}$ and $\mathrm{F} / \mathrm{N}$ ). Forest growth consisting of trembling aspen (Populus tremuloides), willow, birch, black spruce and white spruce (Picea glauca) is inhibited on the wetter of these Gleysols. Gleysols develop on glaciolacustrine clays in the Fraser Basin and on moderately fine textured glacial till. Forested Organics support black spruce, labrador tea and moss and the wetter of these have sedges and mosses on elevated positions.

Gleysolics, similar to those described by Cotic (1974), occur in the northwestern part of the central interior in the Nechako Plateau (Runka 1972, 93 LSE, LN, M/SW). Nonforested Gleysols also occur on silty alluvial materials underlain by sand or gravel along with forested (Mesisols) and nonforested (Fibrisols) Organics.

Strongly acidic Typic Fibrisols, saturated with stagnant water and Typic Mesisols saturated with moving water, occur in the northern part of the central interior in the Nechako Plateau between 600 and $1200 \mathrm{~m}$. Terric and Fibric Mesisols, Terric and Mesic Fibrisols and peaty phases of Humic Gleysols associate with these soils (Epp and Kenk 1983, 93 K/N, N).

The Hazelton soil map area covers about $10800 \mathrm{~km}^{2}$. That portion covered by the Nechako Plateau includes two Typic Mesisols and two Typic Fibrisols. Both of these Organic types occur within two elevational ranges: 720 to $1100 \mathrm{~m}$ and 1100 to $1600 \mathrm{~m}$, and both are associated with Rego Humic Gleysols (peaty phase). Humic Luvic and Rego Humic Gleysols are associated with one Gleyed Cumulic Regosol map unit occurring between 720 and 1100 m (Wittneben 1984, 93 $M / N, S E)$.

\subsection{Interior Plateau, South}

The earliest soil survey was conducted by Kelley and Spilsbury $(1949,4900 \mathrm{~N}$ to $5045 \mathrm{~N}$ along $11930 \mathrm{~W}$ ) for the bottoms and adjacent slopes of the Okanagan and Similkameen Valleys and their side valleys, an area of $1397 \mathrm{~km}^{2}$, about $190 \mathrm{~km}$ by 5 to $10 \mathrm{~km}$. They describe ground water soils that include two mineral soil series; one with loam or clay loam textures, probably Orthic Gleysol (ACECSS 1987) covering $4 \%$ of the mapped area; the other with sandy loam, loam, silt loam, clay loam and clay textures, probably Humic Gleysol (ACECSS 1987) (no areal extent given); and a well decomposed bog soil (muck) probably a Humisol (ACECSS 1987) covering $1 \%$ of the mapped area. Many of these mineral soils are covered by vegetation common to the wetter adjacent biogeoclimatic zones that include such tree species as red cedar (Thuja plicata), Douglas-fir (Pseudotsuga menziesii), Engelmann spruce (Picea engelmanni), cottonwood (Populus trichocarpa), birch (Betula occidentalis), aspen (Populus tremuloides) and alder (Alnus spp.) as well as the shrubs willow (Salix spp.), dogwood (Cornus stolonifera), Rocky mountain maple (Acer glabrum), hawthorn (Crataegus), Saskatoon (Amelanchier), chokecherry (Prunus spp.) and hazel (Corylus spp.). The muck soils support grasses, sedges, cattail (Typha latifolia), and rushes (Scirpus spp.) in the wetter parts, and in the drier parts trees and shrubs similar to those of the mineral soils.

Wetland soils of the North Okanagan Valley (Sprout and Kelley 1960, portion $82 \mathrm{~L} / 2,3,6,7,10,11)$ covering a surveyed map area of $601 \mathrm{~km}^{2}$ between 345 and $670 \mathrm{~m}$ elevation, consisted of Gleysols (6.8 \% of that map area) and Organics (2.0\%). Medium textured Orthic Gleysols occupied $1.7 \%$ and a peaty phase $1.1 \%$. Medium to heavy textured Dark Gray Gleysolics (probably Humic Gleyso, ACECSS 1987) were divided into one slightly acidic (0.5\%) and two calcareous (1.5\%) map units, and medium textured ones into a slightly acidic (1.9\%) 
and a calcareous $(0.1 \%$ ) unit. A peat occupied an area of $0.2 \%$ and a muck $1.8 \%$ (probably Mesisol and Humisol ACECSS 1987, respectively).

Dawson and Kelley (1964, portion $82 \mathrm{~L} 15$ ) reported on the Eagle River Valley soil-surveyed map area $\left(403 \mathrm{~km}^{2}\right.$ ) which contains Rego and peaty Gleysols (6.5\% of map area) developed on fine to sandy (coarse) textured materials between 1140 and $1750 \mathrm{~m}$ elevation with deciduous tree, shrub and sedge vegetation. These soils were rated class 3 to 5 (improved) but cost of clearing the forest would be high. A muck (possibly Humic Mesisol, ACECSS 1987) (2\%) is excellent for vegetables when adequately drained and fertilized.

Dawson and Kelley $(1965,82$ LNW and portion L/6) reported on the Shuswap Lakes soil survey area $\left(2918 \mathrm{~km}^{2}\right.$ ) which contains $3 \%$ of pure and complex map units, of Rego, peaty or carbonated Rego Gleysols between 500 and 730 m elevation. Those near Shuswap and Mabel Lakes are hard to drain, requiring dyking and pumping but medium acid (non-carbonated) ones can produce good forage and grain crops (class 3-5). Orthic and Rego Humic Gleysols (2\%) between 540 and 1080 m, like the Gleysols, are good arable soils (class 3-5) with adequate drainage and fertilization. Organics (1.3\%) include shallow and deep mucks (probably Humisols, ACECSS 1987) and calcareous phases of each (class 3-5) and lie between 450 and $730 \mathrm{~m}$ elevation. A peat (probably Terric Mesisol, ACECSS 1987) occurs between 630 and $670 \mathrm{~m}$.

The area of the Okanagan and Similkameen Valleys south of $5000 \mathrm{~N}$ has been resurveyed on a more detailed scale by Wittneben (1986) who classified two organic soils, a Terric Humisol and a Typic Mesisol with a calcareous phase as well as ten Humic Gleysols, some with saline, calcareous or peaty phases.

Wetland soils on the Thompson Plateau of the Princeton (Green and Lord 1979, 92 H/SE) and Tulameen (Lord and Green 1974, $92 \mathrm{H} / \mathrm{NE}$ ) map areas (8059 $\mathrm{km}^{2}$ ) include two Terric Mesisols (0.8\%); two Humic Eluviated Gleysols (probably Luvic Gleysol, ACECSS 1987) (0.2\%); as well as four Humic Gleysols $(0.3 \%)$, one of which is carbonated. Vegetation of the Gleysols at lower elevations consist of cottonwood, willow, sedges, grasses and reeds, while that of Mesisols at lower elevations are dominated by sedges, grasses and shrubs. Mesisols and Gleysols at higher elevations are more acidic and vegetation includes willows, glandular birch and labrador tea with sedges dominating.

The soil-surveyed area $\left(563 \mathrm{~km}^{2}\right.$ ) of the Kettle River Valley and tributaries (Sprout and Kelley 1964, portion $82 \mathrm{E} / 1,2,7-10$ ) contains $0.5 \%$ Carbonated Rego Humic Gleysol which lies between 600 and $1200 \mathrm{~m}$ elevation. Some areas require drainage but others are subject to drought, salinity and erosion. Suitable forage crops are recommended. Peaty Rego Gleysol (1\%) in the same elevational range support a dense forest of cedar, spruce, cottonwood, willow and alder which would entail high development costs but would enable good crops to be grown without irrigation. Peat (probably Mesisol, ACECSS 1987) (0.3\%) between 800 and $900 \mathrm{~m}$ requires adequate drainage and fertilization for forage and coarse grains.

Sprout and Kelley (1963, portion 92 l/10,11,14,15) described a silt loam Calcareous Meadow soil (1.3\% of total land area) and a silt loam Saline Meadow (probably Humic Gleysol, calcareous and saline phases, respectively, ACECSS 1987) (0.8\%); and a silt loam Saline Gleysol in the Ashcroft-Savona area $\left(208 \mathrm{~km}^{2}\right.$ ) all between 370 and $700 \mathrm{~m}$ elevation in the main valleys of the Thompson and Bonaparte River systems. These soils support mainly reeds (probably rushes or cat-tail), meadow foxtail (probably Hordeum jubatum), sedges and grasses but all were considered irrigable in this area of high moisture deficit $(-400 \mathrm{~mm} \mathrm{CMB})$. 
Young and Fenger (1992, $92 \mathrm{I}$ ) reported three Organics; two Typic Mesisols (1200 to $1800 \mathrm{~m}$ and 975 to $100 \mathrm{~m}$ elevation ranges) in the Montane Spruce and Interior Douglas - Fir BGCZ, respectively; a Fibrisol (1700 to $1830 \mathrm{~m}$ ) in the Engelmann Spruce and Subalpine Fir zone; and an Orthic Gleysol with silt loam or fine sandy over loamy sand or sand texture in the Interior Douglas-Fir BGCZ associated with Orthic Humic Gleysol and Gleyed Regosol (330 to $480 \mathrm{~m}$ ), improved CCA class 1 to 5 (drained) depending on inundation, saltiness, low moisture holding capacity, topography or stoniness. The Organics were rated class 5 or 6 because of short frostfree period.

\subsection{Northwestern Plateaux and Basin}

Pojar et al. (1983) classified a Cordilleran Boreal subzone of the Boreal White and Black Spruce BGCZ which occupies the northwestern plateaux where black spruce - sphagnum muskeg (bog) occurs but was not as widespread as were minerotrophic wetlands with black and white spruce. Humic Gleysols and Organics occur along with Organic Cryosols, especially on northern aspects in the Alpine Tundra BGCZ.

Wittneben (1984, $93 \mathrm{M} / \mathrm{N}, \mathrm{SE})$ reported one Typic Mesisol which occurs within the 350 to $1050 \mathrm{~m}$ elevation range, three within 1050 to $1700 \mathrm{~m}$ and one Typic Fibrisol within 1100 to $1700 \mathrm{~m}$ elevation in the southern part of the Skeena and/or Omineca Mountains. Most of these Organic map units have Rego Humic Gleysols (peaty phase) associated with them.

Wetlands are not extensive in the subalpine and alpine (J. Pojar, personal communication 1984). Some notable exceptions occur on broad bottoms of the upper valleys of the Stikine, Klappan, Spatsizi and Jennings Rivers of the Stikine Plateau and especially of the Teslin valley of the Yukon Plateau. Extensive alpine wetlands occur only on the Kawdy portion of the Stikine Plateau above Tuya Lake. Discontinuous permafrost may occur on the plateaux, and often can be found in the Organics (Pojar et al. 1983).

\subsection{Liard Plain}

The Boreal White and Black Spruce BGCZ, Northern Boreal subzone (Pojar et al. 1983) almost entirely covers the Liard Plain and Dease Plateau (not shown, Figs 2-7). Black Spruce communities on organic soils are abundant and most bogs have permafrost although it is of minor extent. Tamarack (Larix laricina) and leatherleaf (Chamaedaphne calyculata), an ericaceous shrub, are typical species restricted to the wetlands of this subzone which are best developed in the Liard Plain. Tamarack forms pure stands only on rich (minerotrophic) fens and swamps mainly on the Liard Plain (Pojar et al. 1983). The Spruce - Willow - Birch BGCZ almost entirely covers the Liard Plateau, immediately adjacent in the Mountain group to the east.

A contracted study of the Liard River drainage Basin (Watson Lake to about 5915N 12400W) vegetation covered a map area of $18780 \mathrm{~km}^{2}$, about $2 \%$ of BC total map area (BCHPA 1980). In Alpine areas, moderately gleyed soils, possibly Humic Gleysols (ACECSS 1987) occur but in the upper elevation forest type, Alpine Fir, significant accumulations of moss peat often occur. Gleysolic and/or Organic soils, associated with Podsols and Brunisols, occur under Alpine Fir and Black Spruce - Labrador Tea vegetation types. Willow Shrubland and Bog Birch Scrubland vegetation types occupy Gleysol and Organic sites. The Black Spruce - Tamarack vegetation type is associated with Organic soils derived from a mixture of moss and sedge peats, where its establishment may be due to fire and/or higher nutrient inflow than occurs for other Black Spruce 
types. Black Spruce - Bog - Rosemary - Cassandra vegetation type, associated with Organics derived from moss peats, are extremely mounded due to mossy hummocks and occur at low elevations in the eastern part of the study area. Organic soils associated with Luvisols maintain a Lodgepole Pine - Black Spruce vegetation type. A Sedge Meadow type is found on Organics comprised of sedge peat with Gleysolics commonly occurring. No wetland types were reported for 17 other vegetation types described.

BCHPA (1982) contracted a second study, covering a smaller area (1492 $\left.\mathrm{km}^{2}\right)$ along the Liard River Basin, approximately $0.5 \mathrm{~km}$ beyond the proposed maximum flood area and below $570 \mathrm{~m}$ elevation, the highest of five proposed dam sites. Four major vegetation habitats were identified with these 18 vegetation types. An alluvial vegetation habitat occupies $352 \mathrm{~km}^{2}(24 \%$ of total surveyed area) and a lowland habitat occupies $38 \mathrm{~km}^{2}(3 \%)$. On the basis of vegetation types, these two habitats would likely contain wetland soils - Organic and Gleysol - but the alluvial habitat probably also includes Gleyed Regosol as well as gleyed members of other upland soil orders. Within the alluvial habitat, a riparian type occupies $17 \mathrm{~km}^{2}(1 \%)$, cottonwood forest type $75 \mathrm{~km}^{2}(5 \%)$ and white spruce type $106 \mathrm{~km}^{2}(7 \%)$ for a total of $200 \mathrm{~km}^{2}(13 \%)$. The lowland habitat contains sedge meadow type which occupies $3 \mathrm{~km}^{2}(0.2 \%)$, bog birch scrubland type 110 $\mathrm{km}^{2}(8 \%)$, and white spruce-cottonwood type $231 \mathrm{~km}^{2}(12 \%)$.

The area of alluvial habitat (24\%) and of lowland (3\%) falls only very roughly within the range indicated (Fig. 2) for the Liard Plain and Plateau that was derived from NTS maps. Probably the white spruce - cottonwood type of ailuvial habitat contains little wetland. If this type were not considered, the riparian and cottonwood types would account for $6 \%$. This $6 \%$, plus the lowland $3 \%$ totals $9 \%$, a more compatible amount to that indicated in Figure 2. However, Figure 4 indicates little or no wetland between 300 to $600 \mathrm{~m}$ elevation which is within the elevational range covered by BCHPA (1982). Thus, areal estimates for wetlands taken from BCHPA (1982) might describe the area more accurately if added to those from NTS maps. Probably percent wetland area derived from BCHPA (1982) is overestimated while that from NTS is underestimated.

Walmsley and Lavkulich (1973) developed an in situ procedure for measurement of dissolved materials from organic terrain types. They showed that fen terrain-type material has a higher activity of sodium, chloride and calcium, and a lower concentration of oxygen than bog terraintype material. Their results were explained with reference to organic terrain morphology and the distribution of permafrost in the Watson Lake (southern Yukon) and the Fort Simpson (Northwest Territories) areas.

\subsection{Mountain}

Discussion of soils in this group follows the approximate order of south to north coastal, then north to south for the interior.

Soils of the Tofino-Uclulet Lowland surveyed-area (145 km²; Valentine 1971a, portion 102 $\mathrm{F} / \mathrm{SW}$ ) on the west coast of Vancouver Island include only one wetland soil series represented by a Rego Humic Gleysol covering $3 \%$ of the surveyed area.

Moon and Brierly (1988, portion $92 \mathrm{G} / 11,65 \mathrm{~km}^{2}$ ) reported Orthic Gleysols, peaty phase or Terric Mesisols occurring in the Mountain Hemlock BGCZ parkland subzone and occupying components of three of 22 described soil map units and Gleysols occurring in the Coastal Western Hemlock BGCZ, wet subzone, as inclusions of two other components for the Mill Creek and Woodfibre Creek watersheds. 
The detailed, 1:20 000 scale, soil survey of the Pemberton Valley reports $200 \mathrm{~km}^{2}$ of wetland (Beale-Kuurne 1980, portion $92 \mathrm{~J} / 6,9-11$ ). It includes descriptions of three peaty Rego Gleysols, three peaty Rego Humic Gleysols, 13 Rego Gleysols; a Terric Mesic Fibrisol and a Cumulo Terric Fibrisol; and a Terric Mesisol. Wetland soils of the floodplains include Rego and Rego Humic Gleysols with lesser amounts of Organics. Wetland soils of the Lillooet Valley portion of the survey area are predominantly Cumulo Rego and Rego Gleysols with minor amounts of peaty Rego Gleysols and associated Orthic Regosols and Terric Fibrisols. In this portion of the study area, substantial changes in soil characteristics have occurred and continue to occur due to a major dyking, drainage and river training program initiated in 1946 to improve soil drainage by straightening the river and lowering Lillooet Lake.

The soil survey of the Alta Lake area $\left(38 \mathrm{~km}^{2}\right)$ along the Green River valley leading into Lillooet Lake indicates $2.8 \mathrm{~km}^{2}(7.4 \%)$ Rego Gleysols and $1.3 \mathrm{~km}^{2}(3.4 \%)$ Terric and Typic Fibrisols (Luttmerding 1971, portion $92 \mathrm{~J} / 2,3 ; 1: 15840$ ). This report gives soil interpretations for engineering uses based on qualitative field and limited laboratory data.

Coastal wetlands of the northwestern Coastal Mountains (J. Pojar, personal communication 1984) are not extensive in BC but do occur in southeast Alaska. However, wetlands of the northwestern interior mountains of $\mathrm{BC}$ occur in the broad bottoms of the upper valleys of the Little Rancheria, Turnagain (including Kutcho Creek), Kechika, and Finlay Rivers of the Cassiar Mountains and of the Skeena and Nass Rivers of the Skeena Mountains. Wetlands that occur in a mosaic with grassland and shrub fields along Kluayetz Creek, tributary to the Spatsizi River in the Skeena Mountains, are merely indicated as treeless areas on NTS maps; therefore would not have been included in this study.

An inventory was conducted (Epp and Fenger 1978, portion $104 \mathrm{G} / \mathrm{NW}$ ) along a $60 \mathrm{~km}$ portion of the Stikine River Valley southwest of Telegraph Creek, which covers $270 \mathrm{~km}^{2}$ of surveyed area up to about $600 \mathrm{~m}$ elevation and placed emphasis on areas of CCA class 4 or better. Many soils on the flood plains ( $17 \mathrm{~km}^{2}$ of surveyed area) along the Stikine River are classified as Gleyed Cumulic Regosol (12 km², $5 \%)$. However, Gleysols $\left(2 \mathrm{~km}^{2}, 1 \%\right)$ are common on the lowest portions of these plains where water tables are high and flooding is common. These soils are generally formed on well-sorted, stratified, sandy or silty materials over gravelly deposits. Mesisols and Fibrisols ( $2 \mathrm{~km}^{2}, 1 \%$ combined) occupy scattered depressions on the flood plains. On these soils, organic material is often greater than $60 \mathrm{~cm}$ thickness.

Ryder $(1984,104$ F, G and portion 104 B, H) of the Stikine-Iskut area indicates that areas of organic sediments are widespread in depressions and on poorly drained, level surfaces but are more common than shown on the map scale presented. The thermal properties of organic sediments allow for permanently frozen conditions where other materials will thaw for part of the year. In late summer, permafrost was found in Organics at sites between $750 \mathrm{~m}$ and $1188 \mathrm{~m}$ elevation. Permafrost is likely widespread above $1200 \mathrm{~m}$ but becomes rarer at lower elevations where small pockets exist only in Organics which occur on shaded, moist sites in narrow valleys. Merdinger et al. (1986) report that in the permafrost areas in the Alpine Tundra of the Mackenzie timber supply area of the northern interior mountains, Turbic and Static Cryosols occur and on the wetter sites Organic Cryosols and Organic soils. Permafrost occurs in wet and steep northfacing sites.

In the east central Rocky Mountains and Foothills (Vold et al. 1977, 93 I/9-16 and portion 93 $\mathrm{J} / 9$ and $93 \mathrm{P} / 1-12$ ), two Orthic and one Orthic Luvic Gleysol associated with a peaty phase and a Rego Gleysol, Humic and Humic Luvic Gleysols occur between 600 and $1200 \mathrm{~m}$. In the same elevational range, four Mesisols on bog or fen wetlands are associated with a Lithic Mesisol and 
two Fibrisols are associated with a Sphagno Fibrisol. A Fibrisol at 300 to $1000 \mathrm{~m}$ is associated with a Terric Mesisol and a Terric Fibrisol on bog wetland. Humisols were also reported.

The mapped portion ( $2670 \mathrm{~km}^{2}$ between 600 and $1200 \mathrm{~m}$ elevation) of the upper part of the Fraser Valley in the Rocky Mountain Trench between Valemount and Prince George (Hortie et al. 1970, portions of $83 \mathrm{D} / 11,13,14,83 \mathrm{E} / 4,93 \mathrm{~A} / 16,93 \mathrm{H} / 8-11,13,14,93 \mathrm{I} / 4,93 \mathrm{G} / 16,93 \mathrm{~J} / 1,8$ ) includes a slightly acid Low Humic Eluviated Gleysol (probably Orthic Luvic Gleysol, ACECSS 1987). It covers about $2 \%$ of the mapped portion and about $60 \%$ of it rates CCA class 4 and $6 \%$ class 3 (unimproved). One complex soil map unit (8\%) contains Gleysols and Organics associated with Podzol and Gray Wooded (Luvisol, ACECSS 1987) soils, and a very strongly acid Mesisol, sphagnic phase (4\%), all soil capability 7.

Although commercial agricultural development is not encouraged and its value is low in most of the Canada National Parks of BC, reference is made here to significant studies of these parks for completeness of this report. Similar studies were made for Jasper, Banff, Lake Louise and Waterton National Parks located in the Rocky Mountains of Alberta adjacent to BC. Detailed analyses and interpretations for numerous park uses are made in most of these reports.

The Yoho National Park study (Coen et al. 1977, portion 82 N/E; 1:50 000) covers $1300 \mathrm{~km}^{2}$ from valley bottoms above $1000 \mathrm{~m}$ to mountain peaks up to $3540 \mathrm{~m}$ elevation. The climate is classified as humid to subhumid cold cryoboreal. Gleysols and Organics, with neutral reaction, occur in seepage and pond areas generally near the valley bottoms.

An ecological land classification study (Alberta Institute of Pedology 1984b, portions $82 \mathrm{M} / 1$, 82 N/SW; 1:50 000) of the Mount Revelstoke and Glacier National Parks indicates that Gleysols have a wider distribution than Organics. Episodes of fluvial (mineral) decomposition preclude the buildup of thick organic layers and allow only Rego Gleysolic development. Orthic Gleysols, however, develop on stable landscapes. Organic Fibrisols on fen peat predominate over Mesisols. Most Organics are thought to be Terric subgroups. Some Organics develop, or are enhanced, by dam-building activity of beavers. Humic horizons and Humisols are rare. The wetland soils support shrub thickets, spruce open-forest and other wetland species. They occur in vegetation zones equivalent to the Interior Cedar - Hemlock and Engelmann Spruce Subalpine Fir BGCZ of BC. Wetlands occur only rarely in the Alpine because of steep topography. Wetland soil development was discussed in relation to that of gleyed subgroups (imperfectly drained) of the three upland soil orders (Podsol, Brunisol and Regosol) that occur in these two National Parks.

Similar wetland soils are described for Kootenay National Park (Alberta Institute of Pedology $1984 \mathrm{a}$, portions of $82 \mathrm{~J} / 12,13,82 \mathrm{~K} / 9,16,82 \mathrm{~N} / 1,2,7,8,82 \mathrm{O} / 4$ ) that occur in vegetation zones equivalent to Montane Spruce and Englemann Spruce - Subalpine Fir BGCZ of BC.

Wetland soils of a surveyed area $\left(1111 \mathrm{~km}^{2}\right)$ of the upper Columbia River Valley of the East Kootenay District of BC (Kelley and Holland 1961, portion within $5009 \mathrm{~N}$ to $5132 \mathrm{~N}$ and $11456 \mathrm{~W}$ to $11716 \mathrm{~W}$ ), cover $224 \mathrm{~km}$ in the Rocky Mountain Trench below about $1000 \mathrm{~m}$ elevation, including a poorly drained complex and originally covered about $186 \mathrm{~km}^{2}(2 \%)$ of the surveyed area. Much of this complex area is now flooded by McNaughton Lake created by the BC Hydro Mica Creek dam. A medium acid, deep peat, calcareous at depth, (probably Mesisol, ACECSS $1987)$ covers only $0.5 \mathrm{~km}^{2}(0.05 \%)$ of the surveyed area. Other poorly drained areas occupy 11 $\mathrm{km}^{2}(1 \%)$. 
The soil surveyed area (3544 $\left.\mathrm{km}^{2}\right)$ of the upper Kootenay and Elk River Valleys in the East Kootenay District of BC (Kelley and Sprout 1956, portions from 4900N between $11554 \mathrm{~W}$ and $11514 \mathrm{~W}$ to $5038 \mathrm{~N}$ [Kootenay] and to $5007 \mathrm{~N}$ [Elk]) below about $1000 \mathrm{~m}$ elevation includes groundwater soils (probably Orthic Gleysol and/or Gleyed Regosol, ACECSS 1987) with silt loam texture which covers $116 \mathrm{~km}^{2}(3 \%)$ of the surveyed area. Over $75 \%$ of this area, which was mostly good arable land, is now flooded by Lake Koocanusa created by the Libby Dam in adjacent Montana, USA. A small amount of that remaining land is arable (soil capability for agriculture Class 4 or better). Similar soils with sandy loam texture $\left(53 \mathrm{~km}^{2}, 2 \%\right)$, a muck soil (probably Humisol, ACECSS 1987) $\left(4 \mathrm{~km}^{2}, 0.1 \%\right)$ and another $10 \mathrm{~km}^{2}(0.3 \%)$ of swamp land make up these wetland soils.

Alluvial wet soils are present in every major valley of the east Kootenay map area (25 $028 \mathrm{~km}^{2}$; Wittneben 1969; S of $5115 \mathrm{~N}, \mathrm{E}$ of $11630 \mathrm{~W}$ ) and are dominant on the wide flood plains of the two major rivers, the Kootenay and Columbia, and often have a Regosolic and/or Gleysolic development. Their texture ranges from coarse through medium to fine. Gleysols are found mostly in depressional and poorly to very poorly drained areas on the flood plains. The morphology of these soils is often a function of the variable intensity and permanency of restricted drainage and local conditions and thus are classified as either Humic Gleysols, Gleysols or Eluviated Gleysols (Luvic Gleysols, ACECSS 1987). The land forms upon which these soils occur are usually the old meander channels and oxbows expressed by a microtopography of shallow depressions, ponds and swamps. Where local conditions of parent material in the alpine areas favour impeded drainage or where patches of snow last for much of the year, the soils become water-saturated and develop to Gleysols or gleyed members of the related alpine Dystric or Eutric Brunisol upland soils. These wet soils (probably Gleysol, peaty phase, ACECSS 1987) would often develop on a peaty layer that may be up to two feet thick over gleyed mineral materials.

Lacelle (1990; S of $5108 \mathrm{~N}, \mathrm{E}$ of $11600 \mathrm{~W}$ ) described wetland soils occurring as common and less common porportions of several imperfectly, poorly and very poorly drained components of various soil associations developed on different geologic materials in the East Kootenay area. Rego Gleysol, some grading to Gleyed Cumulic Regosol, Rego Gleysol calcareous phase and Terric Mesisols occur in the Interior Douglas Fir BGCZ between 700 to $1800 \mathrm{~m}$ elevation, the Interior Cedar Hemlock BGCZ between 1200 and $1800 \mathrm{~m}$, and the Engelmann Spruce Subalpine Fir BGCZ between 1350 and $2300 \mathrm{~m}$. Typic Mesisol components occur in the Interior Douglas-Fir and Engelmann Spruce - Subalpine Fir BGCZ with less common proportions of Terric Mesisol and Rego Gleysol, calcareous phase but also with Typic Fibrisol in the Engelmann Spruce - Subalpine Fir BGCZ. Lacelle(1990, pp 357-359) provides a table correlating his current survey soil associations with previous surveys in, or adjacent to, the East Kootenay area.

Lardeau map area (15 $801 \mathrm{~km}^{2}$. Wittneben 1980, $82 \mathrm{~K}$ ) contains $29 \mathrm{~km}^{2}(0.2 \%)$ of one map association of medium textured Orthic Humic Gleysol often associated with Orthic Gleysol and gleyed Orthic Regosol, often calcareous. Most are being used for production of a wide range of agricultural crops. Seepage phases of upland soil orders occur on steep slopes in the mountainous terrain and are periodically saturated with nutrient-rich, oxygenated waters. They, and other wetland soils, are characterized by lush vegetation of the Interior Cedar - Hemlock BGCZ, including cottonwood. The seepage phase soils have high organic matter accumulations. These soils are not included in this present study. Gleysols and Organics greater than $50 \mathrm{~cm}$ depth $\left(2 \mathrm{~km}^{2}, 0.01 \%\right)$ occur in the main valley bottoms.

Nelson map area (16 $128 \mathrm{~km}^{2}$, Jungen 1980, 82 F) includes Orthic and Rego Humic Gleysols (0.4\% of map area, pure and complex map units), Carbonated (calcareous phase, ACECSS 1987), Rego and Orthic Gleysols, and Rego Gleysols (0.5\%) associated with gleyed Regosols 
and Low Eluviated Humic Gleysols (Humic Luvic Gleysols, ACECSS 1987). A detailed soil survey of the Creston area (Wittneben and Sprout 1971, portion 82 F/SE) which lies within the Nelson soil-survey map area has been updated.

The Carbonated Gleysols occupy deep silty calcareous alluvial deposits of the Kootenay River at the south end of Kootenay Lake known as Creston Flats, much of which is dyked and drained. Most of these Gleysols lie between 460 and 540 m elevation, with a few up to $1370 \mathrm{~m}$. Mesisol and Humisol Organics (0.02\%) occur in the drier parts of the Interior Cedar - Hemlock BGCZ. Seepage phases of upland soil orders also occur in this map area (82 F) but are not included in this present review.

The Seymour Arm soil-surveyed map area (15 452 km², Kowall 1980, 82 M) includes mainly acid Organics; two sphagno Fibrisols, one (0.3\% of map area) above $1500 \mathrm{~m}$ elevation in the Interior Cedar - Hemlock BGCZ and the other (0.6\%) between 1200 and $2000 \mathrm{~m}$ in the Engelmann Spruce - Subalpine Fir BGCZ; and one Typic Mesisol (0.01\%) at less than $1400 \mathrm{~m}$ in the Interior Douglas-Fir. There are limited areas, mainly at low elevation, in which impeded drainage is dominant and Gleysolics $(0.08 \%)$ occur in association with Organics.

The south and west portions of the Princeton soil-surveyed area (Green and Lord 1979, 92 H/SE) cover most of the southeast portion of the Cascade Mountains. Here two medium acid, fine textured Rego Humic Gleysols and a Typic Mesisol with Terric Mesisol inclusions are associated with the well-drained alpine soils, Sombric and Orthic Humo-Ferric Podsol and Degraded Dystric Brunisol at high elevations. A detailed soil survey of a subalpine-alpine transect above $2100 \mathrm{~m}$, on the north facing slope of Lakeview Mountain in Cathedral Park, covering $6 \mathrm{~km}^{2}$ indicated that $0.3 \mathrm{~km}^{2}(5 \%)$ is occupied by wetland soils (van Ryswyk 1969, portion of $92 \mathrm{H} / 1$ ).

\subsection{Fort Nelson Lowland}

Green and Lord (1978) presented a concise overview of wetland landscapes of the BC portion of the Alberta Plateau subdivision of the Canadian Interior Plains physiographic region (Holland 1976). An excerpt from their report follows:

The Luvic Gleysol landscape This soil landscape occurs on the wetter margins of the Gray Luvisol landscape. The moisture regime is humid for most of the year, but there are short periods of complete saturation (subaquic regime). The landscape is found most commonly on the northern border of the lowlands where fine textured, nearly impervious materials occupy poorly drained level to depressional areas with sedge, willow and other moisture-loving forms of vegetation.

A typical Luvic Gleysol has a thin layer of raw organic litter on the soil surface; a bleached, gray, mottled, platy Aeg horizion, 5 to $10 \mathrm{~cm}$ thick; a dark gray, mottled Btg horizon with rounded or subangular blocky structures (when dry), 10 to $15 \mathrm{~cm}$ thick; and a mottled light olive brown $\mathrm{C}$ horizon.

Although saturated for short periods they are well enough aerated for clay translocation to have occurred. Since they occupy areas that receive runoff from surrounding higher areas, they usually have more bases than the Gray Luvisols. However, like the Gray Luvisols they need the addition of nitrogen and organic matter for crop production. Poor natural drainage and the promotion of poor physical 
condition if worked when too wet are also important factors limiting the agricultural productivity of Luvic Gleysols.

The Organic soil landscape The Fibrisols and Mesisols that make up these landscapes occupy extensive tracts of level or depressional ground in the Peace River and Fort Nelson lowlands as wetter associates of the Luvic Gleysols.

They are saturated for moderately long periods of time (aquic regime), and organic matter accumulates on the surface of the mineral soil. These landscapes (with the Organic Cryosol discussed below) are the "muskeg" that is such a fascinating but perplexing part of northern Canada. It has been perplexing mainly to engineers who have had to build roads, railways or pipelines through this very wet, very cold and often very unstable land. The organic surface is usually quite thin, commonly less than $1 \mathrm{~m}$. But it acts as a huge sponge that regulates stream flow by holding and slowly transmitting vast quantities of water. If the sponge is disturbed by route construction the water may be released quickly to cause extensive erosion.

The peat is moderately (Mesisol) or poorly (Fibrisol) decomposed plant residues, mainly mosses and sedges. It is usually reddish to yellowish brown in colour and below it there will be strongly gleyed sands, silts or clays. It is moderately to very strongly acid and very low in nutrients. This is because most of the soil water is derived from precipitation; it has not accumulated as runoff from surrounding uplands from which it would have carried dissolved nutrients, as is the case with the organic soils of the Interior Plateau. Mesisols have a vegetation cover of sedges, hypnum mosses, blueberries and bog glandular birch. Fibrisols have sphagnum mosses, common Labrador tea and stunted black spruce and tamarack.

The Organic Cryosol landscape This soil landscape which occurs in the Fort Nelson Lowland consists of organic soils [Organic Cryosols; ACECSS 1987] that have permafrost within $1 \mathrm{~m}$ of the surface. The southern limit of discontinuous permafrost is just south of the $-1{ }^{\circ} \mathrm{C}$ mean annual isotherm which crosses the region at about $58 \mathrm{~N}$ latitude [5800N]. From here to the 60 th parallel [6000N] parts of the organic terrain will have layers that do not thaw in the summer, because they are effectively insulated by the surface peat. Not all the peatland will be frozen, neither will all of it have a thick organic cover. Therefore, there is a very complicated pattern of Organic Cryosol, Organic and Luvic Gleysol landscapes in the Fort Nelson Lowland.

The surface of these soils is poorly decomposed reddish or yellowish brown fibric peat. Below this the frozen peats looks very similar. It just feels hard. There are no large ice lenses only ice coatings on all the organic fibres that bind them together. The vegetation cover is also similar to the Fibrisol landscape with sphagnum mosses, Labrador tea, stunted black spruce and tamarack.

With the unfrozen Organic soil landscape this forms part of the muskeg terrain of the north. It presents all the same problems of use as the unfrozen soils with the added difficulty of a frozen layer whose upper surface fluctuates in depth throughout the year. 
Valentine (1971b, $94 \mathrm{~J} / \mathrm{NE}, 3108 \mathrm{~km}^{2}$ ) reported that wetland soils cover $66 \%$ of the surveyed area with strongly acid Cryic Fibric Mesisol or Cryic Fenno Fibrisol (Cryosols, ACECSS 1987) covering $39 \%$ of the surveyed area with acid Terric Fibric Mesisol (10\%), neutral Terric Humic Fibrisol (7\%), Rego Gleysol (4\%), Rego Humic Gleysol (4\%), and one Carbonated Orthic Humic Gleysol (2\%). Kowall (1982, $94 \mathrm{O} / \mathrm{S}$ and portions of $94 \mathrm{~J} / \mathrm{NW}$ ) reported similar wetland soils for an adjacent area but included several others classified as Organic Cryosols. Meidinger and Lewis (1983) described the vegetation on various wetland sites that included black spruce as a common tree species but with different undercover communities depending on wetness and nutrients.

\subsection{Peace River Lowland}

Farstad et al. (1965, within $5530 \mathrm{~N}$ to $5715 \mathrm{~N}$ and $12000 \mathrm{~W}$ to $12200 \mathrm{~W}$ ) prepared the first soil report for the Peace River map area. Subsequently Lord and Green (1986, 93 P/N, 94 AVS) updated the report according to newer mapping and classification systems (Canada Expert Committee on Soil Survey 1983, Canada Soil Survey Committee 1978, respectively) and revised certain map unit descriptions and delineations for a large portion (total map area $13900 \mathrm{~km}^{2}$ ) of the same area covered by Farstad et al. (1965). Lord and Green (1986) described two Organics (covering $4 \%$ of the total map area), two Orthic Luvic Gleysols (3\%), two Orthic Humic Gleysols $(3 \%)$, one with a peaty phase, and one Carbonated Rego Humic Gleysol (1\%). Green and Lord (1973, 94 H/S), Lord (1974, 94 B/NE) and Lord and Green (1973, 94 A/N) prepared soil maps for adjacent areas as indicated.

A Terric Mesisol occurs on medium acid to neutral sedge fen peat at 600 to $700 \mathrm{~m}$ elevation while another Terric Mesisol, with sphagnic phases, occurs on strongly acidic sphagnum moss or forest peat in flat bog wetland at 600 to $900 \mathrm{~m}$. Frozen layers sometimes persist into late summer on these latter Mesisols.

The Gleysols generally occur below $750 \mathrm{~m}$ on fine textured morainal or lacustrine material but one Orthic Humic Gleysol occurs at $900 \mathrm{~m}$ on sandy silty sediments. Natural vegetation of these Gleysols include the usual wetland species -- white spruce, willow, ground (glandular) birch, Labrador tea, sedges, grasses, reeds and mosses.

The soil survey of the East Moberly Lake Indian Reserve No. $169\left(34 \mathrm{~km}^{2}\right)$ indicates that Terric Mesisol and Terric Mesisol, sphagnic phase (Wiken and Farstad 1973a, portion 93 P/13E)) map units occur in association with several well-drained soils on $17 \mathrm{~km}^{2}(50 \%)$ of this area. These Organics have a high water table throughout the year but the areal extent of each map polygon was considered to be too small to warrant its development at the time of the survey. A portion of the $10 \mathrm{~km}^{2}$ of arable land of the West Moberly Indian Reserve No. 168A contains Terric Mesisol (Wicken and Farstad 1973b, portion $93 \mathrm{P} / 13 \mathrm{~W}$ ). 


\section{LITERATURE CITED}

Agriculture Canada. 1984. Atlas of suitable grape growing locations in the Okanagan and Similkameen valleys of British Columbia. Available from Agriculture Canada Research Station, Summerland, B.C. VOH IZO. 141 pp.

*Agriculture Canada Expert Committee on Soil Survey (ACECSS). 1987. The Canadian System of Soil Classification. Agric. Can. Pub. 1646, 2nd edition. Can. Govt. Pub. Centre, Supply and Services, Ottawa. 164 pp.

*Alberta Institute of Pedology. 1984a. Ecological land classification of Kootenay National Park, British Columbia. Vol. I: Integrated Resource Description, Chap. I and II, pp. 1-133. P.L. Achuff, W.D., Holland, G.M. Coen and K. van Tighem (eds.). Environment Canada, Agriculture Canada and Alberta Institute of Pedology. Alberta Institute of Pedology Pub. No. M-84-10. 373 pp. (portion 82 J/12,13; 82 K/9,16; 82 N/SE; 82 O/4; $1: 50$ 000)

*Alberta Institute of Pedology. 1984b. Ecological land classification of Mount Revelstoke and Glacier National Parks, British Columbia. Vol. I: Integrated Resource Description, Chap. II and III, pp. 23-82. P.L. Achuff, W.D. Holland, W.D., G.M. Coen and K. van Tighem (eds). Environment Canada, Agriculture Canada and Alberta Institute of Pedology. Alberta Institute of Pedology Pub. No. M-84-11. 261 pp. (portions $82 \mathrm{M} / 1 ; 82 \mathrm{~N} / \mathrm{SW} ; 1: 50000$ )

Banner, A., Hebday, R.J., Oswald, E.T., Pojar, J. and Trowbridge, R. 1988. Wetlands of Pacific Canada, Chap. 8:304-346 National Wetlands Working Group (NWWG) in Wetlands of Canada. Ecological Land Classification Series No. 24. Sustainable Development Branch, Environment Canada, Ottawa, Ontario, and Polyscience Publications Inc., Montreal, Quebec. 452 pp.

"Banner, A., Pojar, J. and Trowbridge, R. 1986. Representative wetland types of the northern part of the Pacific Oceanic Wetland Region. Research Report RR 85008-PR, B.C. Min. of Forests, Victoria, B.C. $45 \mathrm{pp}$.

"Beale-Kuurne, R.L. 1980. Soil Survey of the Pemberton Valley British Columbia. RAB Bull. 16., B.C. Min. Environ., Resource Analysis Br., Victoria, B.C. 234 pp (portion 92 J/7,9-11; 1:20 000).

Beets, M.L. and Sidney, M. 1975. Cariboo meadow land report. Mimeo presented to the Cariboo (Region v) Inter-Sector Committee by B.C. Min. Environ., Fish and Wildlife Br., Williams Lake, B.C. 18 pp. Appendices.

*Bertrand, R.A., Hughes-Games, G.A. and Nikkel, D.C. 1991. Soil management handbook for the Lower Fraser Valley. 2nd Ed. B.C. Ministry of Agriculture, Fisheries and Food. Abbotsford, B.C. 109 pp. (Appendices).

Bomke, A.A. and Bertrand, R.A. 1983. Response of an orchardgrass-perennial ryegrass sward to rate and method of urea and ammonium nitrate application. Can. J. Soil Sci. 63:719-725.

Bomke, A.A. and Lowe, L.E. 1991. Trace element uptake by two British Columbia forages as affected by poultry manure application. Can. J. Soil Sci. 71(3): 305-312.

"Specifically cited in "Supplementary Wetland Soil Information" section 7. 
British Columbia Department of Agriculture (BCMAFF). 1976. Agriculture land capability in British Columbia. A report coordinated and published by the British Columbia Environment and Land Use Committee Secretariat for the B.C. Dept. Agric. and the Canada Department of Regional Economic Expansion under ARDA Project No. 89077. 44 pp.

*British Columbia Hydro and Power Authority (BCHPA). 1980. Liard River Basin vegetation studies. Final draft report prepared by Techman Ltd. and Ceska Geotechnical Res. Co. for B.C. Hydro and Power Auth. Vancouver, B.C. 75 pp.

*British Columbia Hydro and Power Authority (BCHPA). 1982. Liard River Hydroelectric project: vegetation habitat mapping. Preliminary draft prepared by Hugh Hamilton Ltd. B.C. Hydro and Power Auth., Vancouver, B.C. 18 pp. Appendices and maps. (Watson Lake to 5915N 12400W; $1: 50$ 000).

British Columbia Ministry of Agriculture and Fisheries (BCMAFF). 1989. Vegetable production guide for commercial growers. B.C. Min. Agric. and Fish., Victoria, B.C. 114 pp.

*British Columbia Ministry of the Environment (BCME). 1978a. Climatic capability classification for agriculture in British Columbia. RAB Technical Paper I. Climate Division, Resource Analysis Br., B.C. Min. Envir., Victoria, B.C. 23 pp.

British Columbia Ministry of Environment. 1978b. The soil landscapes of British Columbia. Valentine, K.W.G., Sprout, P.N., Baker, T.E. and Lavkulich, L.M. (eds.). B.C. Min. Envir., Victoria, B.C. $197 \mathrm{pp}$.

British Columbia Ministry of the Environment. 1981. Climatic capability classification for agriculture in British Columbia. APD Technical Paper 4, Assessment and Planning Division, B.C. Min. Envir., Victoria, B.C. 23 pp.

British Columbia Ministry of Forests (BCMF). 1988. Biogeoclimatic Zones of British Columbia. B.C. Min. Forests, Victoria, B.C. (map 1:2 000 000; expanded legend).

Brown, R.J.E. 1977. Muskeg and Permafrost. pp 148-163 in Muskeg and the Northern Environment in Canda. N.W. Radforth and C.O. Browner(eds). Proceedings 15th Muskeg Research Conference. 1973. Edmonton, Alta. Muskeg Subcommittee of the National Research Council Associate Committee on Geotechnical Research. University of Toronto Press. 399 pp.

*Canada Expert Committee on Soil Survey. 1983. The Canada Soil information system (CANSIS) manual for describing soils in the field (rev.) Agriculture Canada Land Resource Research Institute. Contrib. No. 82-52, Ottawa, Ont. 97 pp.

Canada Soil Survey Committee. 1978. The Canadian system of soil classification. Can. Dept. Agric. Publ. 1646. - Supply and Services Canada, Ottawa, Ont. 164 pp.

Cariboo Poorly Drained Soils Development Extension Committee. 1992. Forage production on poorly drained soils in the southern interior of British Columbia. B.C. Min. Agric., Food and Fisheries, B.C. 28 pp. 
Chatterton, A., Senyk, J.P. and Vold, T. 1980. Description of soils for northern Vancouver. Island. Working report. B.C. Min. Envir., Victoria, B.C. 115 pp. (W. of 12600W; 1:50 000 map not included).

*Cheesman, G.E. and Davis, R.L. 1982. The agroclimate of the Peace River valley and a comparison with other locations in British Columbia. Technical report presented to British Columbia Utilities Commission, June 1982. B.C. Min. Envir., Victoria, B.C. 14 pp.

${ }^{*}$ Coen, G.M., Epp, P.F., Tajek, J. and Knapik, L. 1977. Soil survey of Yoho National Park, Canada. Alberta Soil Survey Report No. 37. Alberta Institute of Pedology, No. S-77-37. Agric. Can., Research Br., Edmonton, Alta. Land Resources Research Institute Pub. No. 1. Alberta Institute of Pedology, University of Alberta, Edmonton, Alta. 208 pp. (portion 82 N/E; 1: 125000 and 1:50 000).

${ }^{*}$ Comar, V.K., Sprout, P.N. and Kelley, C.C. 1962. Soil survey of Chilliwack map area. Preliminary Report No. 4 of the Lower Fraser Valley Soils Survey. B.C. Dept. Agric., Kelowna, B.C. 92 pp. (92 G/1, H/4; 1:24 000 map not included).

*Cotic, I. 1974. Soils of the Nechako-Francois Lake area. Mimeo. Interim Report, B.C. Dept. Agric., Soils Br., Kelowna, B.C. 218 pp. (93 K/S, F/N; 1:125 000).

*Dawson, A.B. 1989. Soils of the Prince George-McLeod Lake area. B.C. Soil Survey Report No. 23. B.C. Min. Envir. Tech. Rpt. 29. B.C. Min. Environ. and B.C. Min. Agric. and Fish., Soils Br., Victoria, B.C. 219 pp. (93 G/N, J/S map not included).

*Dawson, A.B. and Kelley, C.C. 1964. Soil survey of the Eagle River Valley British Columbia. Mimeo. Interim Report. B.C. Dept. Agric., Kelowna, B.C. 71 pp. (portion 82 L/15; 1:31 680 map not included).

*Dawson, A.B. and Kelley, C.C. 1965. Soil survey of the Shuswap Lakes area, British Columbia. Mimeo. Interim Report. B.C. Dept. Agric., Kelowna, B.C. 232 pp. (82 LNWW; portion of 82 L/6; 1:31 680 map not included).

*Day, J.H., Farstad, L. and Laird, D.G. 1959. Soil survey of southeast Vancouver Island and Gulf Islands, British Columbia. Can. Dept. Agric., Research Br., Univ. of B.C. and B.C. Dept. Agric. B.C. Soil Survey Report No. 6. Can. Dept. Agric., Research Br., Queen's Printer, Ottawa. 104 pp. (portion 92 BN; C/9; F/SE NW; 1:63 360).

*Dendron Resource Surveys Ltd. 1985. Peatlands of the Pacific coast of British Columbia. Mimeo. Scientific Authority, C. Tarnocai. Agric. Can., Research Br., Land Resource Research Inst., Ottawa, Ont. 75 pp.

de Vries, J. 1988. Hydrophysical characteristics of organic soils and horizon, pp. 34-60 in Organic soils and horizons. Proc. 11th B.C. soil science workshop, Feb. 19-20, 1987, Vancouver, B.C. B.C. Min. Agric. and Fish., Victoria, B.C. 213 pp.

Driehuzen, M.G. 1982. Preliminary results of water control with subsurface drains on interior wetlands in British Columbia. Mimeo. Presented at Agric. Institute Agrology Annual Meeting, July 11-15, 1982, UBC, Vancouver, B.C., Soils Branch, BCMAFF, Cloverdale, B.C. 16 pp. 
Driehuyzen, M.G. 1983. Degradation effects of improper water management, pp. 132-142 in Soil degradation in British Columbia. Proc. 8th B.C. soil science workshop, Feb. 17-18, 1983, Harrison Hot Springs, B.C. B.C. Min. Agric. and Food, Victoria, B.C. 273 pp.

Driehuyzen, M.G. 1988. Water management of organic soils, pp. 116-133 in Organic soils and horizons. Proc. 11th B.C. soil science workshop, Feb. 19-20, 1987, Vancouver, B.C. B.C. Min. Agric. and Fish., Victoria, B.C. 213 pp.

Environment Canada Lands Directorate. 1970. Canada land inventory. Objectives, scope and organization. Revised edition. Min. of Regional Economic Expansion, Supply and Services Canada, Ottawa, Ont. 61 pp.

Environment Canada Lands Directorate. 1976. Canada land inventory. Land capability for agriculture. Prelim. Report. Envir. Can., Lands Dir., Ottawa, Ont. 27 pp.

״Epp, P.L. and Fenger, M.A. 1978. Soil and agricultural capability inventory of the Telegraph Creek area, British Columbia. Mimeo. B.C. Min. Envir., Resource Analysis Branch, Kelowna, B.C. 21 pp. (portion $104 \mathrm{G} / \mathrm{NW} ; 1: 50$ 000).

${ }^{\star}$ Epp, P.L. and Kenk, E. 1983. Soils of the Manson River-Fort Fraser map area. B.C. Soil Survey Report No. 46 B.C. B.C. Min. Envir. Tech. Report No. 1. B.C. Min. Envir., Surveys and Resource Mapping Br., Victoria, B.C. 119 pp. (93 K/N, N; map not included).

*Equus Consulting. 1990. Into the nineties: a sectoral profile and situation analysis of the beef industry of British Columbia. A study for the B.C. Beef Industry Development Council, Vancouver, B.C. $65 \mathrm{pp}$.

Farley, A.L. 1979. Atlas of British Columbia. University of B.C. Press, Vancouver, B.C. 136 pp.

*Farstad, L. and Laird, D.G. 1954. Soil survey of the Quesnel, Nechako, Francois Lake and Bulkley-Terrace areas in the central interior of British Columbia. B.C. Soil Survey Report No. 4. Can. Dept. Agric., Exper. Farm. Serv., Univ. B.C. and B.C. Dept. Agric. Queen's Printer, Ottawa, Ont. 88 pp. (Major valleys west and south of Prince George; 1:126 720).

*Farstad, L., Lord, T.M., Green, A.J. and Hortie, H.J. 1965. Soil survey of the Peace River area in British Columbia. B.C. Soil Survey Report No. 8. Univ. of B.C., B.C. Min. Agric. and Can. Dept. of Agric., Research Br. Queen's Printer, Ottawa, Ont. 114 pp. (within 5530 to $5715 \mathrm{~N}$ and 12000 to 12200 W; $1: 126$ 720).

Fenger, M.A. 1987. A proposal for a multi-agency inventory for the Cariboo-Chilcotin wetlands, pp.403-410 in Wetlands/Peatlands '87, C.D.A. Rubec and R.P. Overend (eds.). Proc. Symposium Wetlands/Peatlands 1987. Ottawa, Ont. 704 pp.

Glooschenko, W.A., Martini, I.P., Clark-Whistler, K. 1988. Salt marshes in NWWG 1988 Wetlands of Canada, Ecological Land Classification Series, No. 24. Sustainable Development Branch, Environment Canada, Ottawa, Ontario, and Polyscience Publications Inc., Montreal, Quebec. 452 pp.

*Gough, N.A. 1988. Soils of the Bonaparte River - Canim Lake map area. B.C. Soil Survey Report No. 24. B.C. Min. Envir. and Parks, Tech. Report 24. B.C. Min. Agric. and Fish., B.C. Min. of Envir. and Parks, Victoria, B.C. 229 pp. (92 P/E) 
Green, A.J. 1988. An Organic soil problem on a Vancouver Island cranberry farm, pp.106-115 in Organic soils and horizons. Proc. 11th B.C. soil science workshop, Feb. 19-20, 1987, Vancouver, B.C. B.C. Min. of Agric. and Fish., Victoria, B.C. 213 pp.

*Green, A.J. and Lord, T.M. 1973. Soils of the Nig Creek-Big Arrow Creek area, British Columbia. B.C. Soil Survey Report No. 19. Agric. Can., Vancouver, B.C. (94 H/S map only; $1: 125000)$.

*Green, A.J. and Lord, T.M. 1978. The great plains, pp. 161-172 in The soil landscapes of British Columbia, K.W.G. Valentine et al. (eds.). B.C. Min. Envir., Victoria, B.C. 197 pp.

*Green, A.J. and Lord, T.M. 1979. Soils of the Princeton area, British Columbia. B.C. Soil Survey Report No. 14. Agric. Can., Research Br., Supply and Services Canada, Ottawa, Ont. 134 pp. (92 H/SE; 1:125 000).

*Green, A.J., van Vliet, L.J.P. and Kenney, E.A. 1989. Soils of the Gulf Islands of British Columbia. Vol. 3. Soils of Galiano, Valdes, Thetis, Kuper and lesser islands. B.C. Soil Survey Report No. 43. Land Resource Research Centre Contr. No. 86-37. Agric. Can., Research Br., Ottawa, Ont. 123 pp. (portion $\mathrm{B} / 13,14, \mathrm{G} / 4 ; 1: 20000$ ).

Gu, B. and Lowe, L.E. 1990. Studies on the adsorption of boron on humic acids. Can. J. Soil Sci: $70: 305-311$.

Guthrie, T.F., and Bomke, A.A. 1980. Nitrification inhibition by N-Serve and ATC in soils of varying texture. Soil Sci. Soc. Am. J. 44:314-320.

Guthrie, T.F. and Bomke, A.A. 1981. Effects of low temperature and nitrification inhibitors on urea hydrolysis. Can. J. Soil Sci. 61:529-532.

*Holland, S.S. 1976. Landforms of British Columbia, a physiographic outline. Bull. No. 48. B.C. Min. Mines and Petroleum Resources, Victoria, B.C. 138 pp. (one map; 1:1 900800 ).

*Hortie, J.J., Green, A.J. and Lord, T.M. 1970. Soils of the upper part of the Fraser Valley in the Rocky Mountain Trench of British Columbia. B.C. Soil Survey Report No. 10. Agric. Can., Research Br. and B.C. Forest Service, Research Div. Queen's Printer, Ottawa, Ont. 55 pp. (portion 83 $\mathrm{D} / 11,13,14 ; 83 \mathrm{E} / 4 ; 93 \mathrm{~A} / 16 ; 93 \mathrm{H} / 8-11,13,14 ; 93 \mathrm{I} / 4 ; 93 \mathrm{G} / 16 ; 93 \mathrm{~J} / 1,8 ; 1: 126$ 720).

John, M.K., Case, V.W. and van Laerhoven, C. 1972. Liming of alfalfa (Medicago sativa L.), I. Effect on plant growth and soil properties. Plant and Soil 37: 353-361.

*Jungen, J.R. 1980. Soil resources of the Nelson map area. B.C. Soil Survey Report No. 28. RAB Bull. No. 20. B.C. Min. Envir., Resource Analysis Br., Kelowna, B.C. 217 pp. (82 F).

*Jungen, J.R. 1985. Soils of Southern Vancouver Island. B.C. Soil Survey Report No. 44. B.C. Min. Envir. Tech. Report 17. B.C. Min. Envir., Surveys and Resource Mapping Br., Victoria, B.C. 198 pp. (between $12300 \mathrm{~N}$ and $12600 \mathrm{~N}$; map not included). 
Jungen, J.R. and Runka, G.G. 1969. Agriculture. Soil capability for agriculture, pp. 86-120 in Lands of the East Kootenay: their characteristics and capability for agriculture and forestry, G.G. Runka (compiler). Mimeo. Report to B.C. Soil Capability for Agriculture and Forestry Committee from a cooperative interim report as part of the Canada Land Inventory Program, B.C. Min. Agric., Victoria, B.C. $180 \mathrm{pp}$. (S of $5115 \mathrm{~N}, \mathrm{E}$ of $11630 \mathrm{~W}$; soil capability overlays for agriculture and forestry, sample area $82 F / 1 E ; 1: 50$ 000).

*Jungen, J.R., Sanborn, P. and Christie, P.J. 1985. Soils of southeast Vancouver Island Duncan-Nanaimo area. MOE Tech. Report No. 15. B.C. Min. Envir., Victoria, B.C. 188 pp. (portions 92 B/NW, F/1, 8; G/4, 5; 1:20 000; maps not included).

"Kelley, C.C. and Farstad, L. 1946. Soil survey of the Prince George area, British Columbia. B.C. Soil Survey Report No. 2. B.C. Dept. Agric. and Dominion Dept. Agric., Exper. Farm. King's Printer, Ottawa, Ont. 58 pp. (93 G/10,15; J/2 and portions 7; 1:190 040).

*Kelley, C.C. and Holland, W.D. 1961. Soil survey of the Upper Columbia River Valley in the East Kootenay District of British Columbia. B.C. Soil Survey Report No. 7. B.C. Dept. Agric. and Can. Dept. Agric., Research Br. Queen's Printer, Ottawa, Ont. 107 pp. (portion within $5009 \mathrm{~N}$ to $5132 \mathrm{~N}$ and $11456 \mathrm{~W}$ to $11716 \mathrm{~W} ; 1: 63360)$.

"Kelley, C.C. and Spilsbury, R.H. 1939. Soil survey of the lower Fraser Valley. B.C. Dept. Agric. and Dominion Dept. Agric. Public. 650, Tech. Bull. 20. Dominion of Can., Dept. of Agric., Ottawa, Ont. 67 pp. (portion of each of $92 \mathrm{G} / \mathrm{l}-3 ; \mathrm{H} / 4,5 ; 1: 63360$ ).

"Kelley, C.C. and Spilsbury, R.H. 1949. Soil survey of the Okanagan and Similkameen Valleys, British Columbia. B.C. Soil Survey Report No. 3. B.C. Dept. Agric. and Dominion Dept. Agric., Exper. Farm. King's Printer, Ottawa, Ont. 88 pp. (4900N to $5045 \mathrm{~N}$ centering on $11930 \mathrm{~W} ; 1: 84480$ ).

"Kelley, C.C. and Sprout, P.N. 1956. Soil survey of the Upper Kootenay and Elk River Valleys in the East Kootenay District of British Columbia. B.C. Soil Survey Report No. 5. B.C. Dept. Agric. and Can. Dept. Agric., Exper. Farm. Queen's Printer, Ottawa, Ont. 99 pp. (portion from 4900N between $11504 \mathrm{~W}$ and $11514 \mathrm{~W}$ to $5038 \mathrm{~N}$ [Kootenay] and to 5007 [Elk]; 1:63 360).

Kenk, E. and Cotic, I. 1983. Land capability classification for Agriculture in British Columbia. B.C. Min. Envir. Manual 1. B.C. Min. Agric. and Food, Soils Br. and Min. Envir., Surveys and Resource Mapping Br., Victoria, B.C. 62 pp.

"Kenney, E.A., van Vliet, L.J.P. and Green, A.J. 1988. Soils of the Gulf Islands of British Columbia. Vol. 2. Soils of North Pender, South Pender, Prevost, Mayne, Saturna, and lesser islands. B.C. Soil Survey Report No. 43. Land Resource Research Centre Contr. No.86-76. Agric. Can., Research Br., Ottawa, Ont. 137 pp. (portion $92 \mathrm{~B} / 11,14 ; 1: 20$ 000).

*Kenney, E.A., van Vliet, L.J.P. and Green, A.J. 1990. Soils of the Gulf Islands of British Columbia. Vol. 4. Soils of Gabriola and lesser islands. B.C. Soil Survey Report No. 43. Land Resource Research Centre Contr. No. 89-61. Agric. Can., Res. Br., Ottawa, Ont. 131 pp. (portion 92 $\mathrm{G} / 4 ; 1: 20$ 000).

Kowalenko, C.G. and Lowe, L.E. 1975a. Evaluation of several extraction methods and of a closed incubation method for studying soil sulfur mineralization. Can. J. Soil Sci. 55:1-8. 
Kowalenko, C.G. and Lowe, L.E. 1975b. Mineralization of sulfur from four soils and its relationship to soil carbon, nitrogen and phosphorus. Can. J. Soil Sci. 55:9-14.

Kowalenko, C.G., Maas, E.F. 1982. Some effects of fertilizer and lime application to filbert orchards in the Fraser Valley of British Columbia. Can. J. Soil Sci. 62:71-77.

Kowalenko, C.G., Maas, E.F. and van Laerhoven, C.J. 1980. Residual effects of high rates of limestone, $\mathrm{P}, \mathrm{K}$ and $\mathrm{Mg}$ applications: evidence of induced $\mathrm{Mn}$ and $\mathrm{Zn}$ deficiency in oats. Can. J. Soil Sci. 60:757-761.

"Kowall, R.C. 1980. Soil and terrain of the Seymour Arm area. B.C. Soil Survey Report No. 16. RAB Bull. No. 19. B.C. Min. Envir., Resource Analysis Br., Kelowna, B.C. 115 pp. (82 M).

"Kowall, R.C. 1982. Soils of the Fort Simpson Trail area. B.C. Soil Survey Report No. 58. APD Bull. No. 25. B.C. Min. Envir., Assessment and Planning Div., Kelowna, B.C. 44 pp. (Appendix) (94 $0 / \mathrm{S}$, portion $94 \mathrm{~J} / \mathrm{NW})$.

Krajina, V.J. 1965. Biogeoclimatic zones and classification of British Columbia. Ecol. West. N. Am. 1:1-17.

"Lacelle, L.E.H. 1990. Biophysical resources of the east Kootenay area: Soils. B.C. Soil Survey Report No. 20. Wildlife Technical Monograph TM 1. B.C. Min. Envir., Wildlife Br., Parliament Buildings, Victoria, B.C. 359 pp. (S. of 5108 N, E of $11600 W$ ).

"Leskiw, L.A. and Farstad, L. 1973. A soil resource and land use survey of the Canim Lake 1 Indian Reserve. Report No. 280. Mimeo. R.E. Carlyle (ed.). Agric. Can., Research Br., Vancouver, B.C. 22 pp. (portion $92 \mathrm{P} / 14 \mathrm{E} ; 15 \mathrm{~W} ; 1: 17850$ ).

"Leskiw, L.A., Farstad, L. and Lord, T.M. 1973a. A soil resource and land use survey of the Williams Lake 1[Sugar Cane] Indian Reserve. Report No. 278. Mimeo. R.E. Carlyle (ed.). Agric. Can., Research Br., Vancouver, B.C. 21 pp. (portion 93 A/4, B/1W; 1:18 365).

"Leskiw, L.A., Farstad, L. and Sneddon, J.I. 1973b. A soil and Land Use Survey of the [Anahim's Flat 1] Indian Reserve. Report No. 274. Mimeo. R.E. Carlyle (ed.). Agric. Can. Research Br., Vancouver, B.C. 26 pp. (portion 93 B/3E; 1:16 900).

Levelton, B.H. and Associates Ltd. Richmond B.C. 1991. An inventory and analysis of control measures for methane for British Columbia. Prepared for B.C. Min. Environ., Air Management Br. (R.J. Williams, Supervisor) Victoria, B.C. 139 pp (Appendices).

Levesque, M., Dinel, H., Lord, T. and Lortie, G. 1987. The characterization of organic soils developed on peat and limnic materials in British Columbia. Agric. Can. Tech. Bull. 1987-5E. Land Resource Research Centre Contr. No. 87-06. Agric. Can., Res. Br., Ottawa, Ont. 49 pp.

*Lord, T.M. 1974. Soils of the Halfway River area of British Collumbia. Map sheet 94 B/NE. B.C. Soil Survey Report No. 18. Agric. Can., Research Br., Vancouver, B.C. (94 B/NE map only; 1:125 000).

"Lord, T.M. 1984. Soils of the Horsefly area, British Columbia. B.C. Soil Survey Report No. 32. Land Resource Research Inst. Contr. No. 84-11. Agric. Can., Res. Br., Supply and Services Canada, Ottawa, Ont. 108 pp. (93 A/W). 
"Lord, T.M. and Green, A.J. 1973. Soils of the Rose Prairie-Blueberry River area, map sheet 94 A/N 1/2, Peace River district, British Columbia. B.C. Soil Survey Report No. 17. Agric. Can., Research Br., Vancouver, B.C. (94 A/N map only; 1:125 000).

*Lord, T.M. and Green, A.J. 1974. Soils of the Tulameen area, British Columbia. B.C. Soil Survey Report No. 13. Agric. Can., Research Br., Information Canada, Ottawa, Ont. 163 pp. (92 H/NE; $1: 126720)$.

"Lord, T.M. and Green, A.J. 1985. Soils of the Barkerville area, British Columbia. B.C. Soil Survey Report No. 40. Land Resource Research Inst. Contr. No. 82-35. Agric. Can., Research Br., Supply and Services Canada, Ottawa, Ont. 79 pp. (93 H/W).

*Lord, T.M. and Green, A.J. 1986. Soils of the Fort St. John-Dawson Creek area, British Colum bia. B.C. Soil Survey Report No. 42. Land Resource Research Centre Contr. No. 85-27. Agric. Can., Research Br., Ottawa, Ont. 130 pp. (93 P/N; 94 AVS).

*Lord, T.M. and Mackintosh, E.E. 1982. Soils of the Quesnel area, British Columbia. B.C. Soil Survey Report No. 31. Land Resource Research Inst. Contr. No. 92. Agric. Can., Research Br., Ottawa, Ont. 93 pp. (93 B/NE, G/SE).

"Lord, T.M. and Walmsley, M. 1988a. Soils of the Nazko area, British Columbia. B.C. Soil Survey Report No. 38. Land Resource Research Centre Contr. No. 85-55. Agric. Can., Research Br., Supply and Services Canada, Ottawa, Ont. 62 pp. (93 B/NW, G/SW).

*Lord, T.M. and Walmsley, M. 1988b. Soils of the Williams Lake-Alexis Creek area, British Columbia. B.C. Soil Survey Report No. 53. Land Resource Research Centre Contr. No. 85-54. Agric. Can., Research Br., Supply and Services Canada, Ottawa, Ont. 72 pp. (93 B/S).

Lowe, L.E. 1988. Chemical characterization of organic soils and horizons, pp. 14-33 in Organic soils and horizons. Proc. 11th B.C. soil science workshop, Feb. 19-20, 1987, Vancouver, B.C. B.C. Min. Agric. and Fish., Victoria, B.C. 213 pp.

Lowe, L.E. and Bustin, R.M. 1985. Distribution of sulphur forms in six facies of peats of the Fraser River Delta. Can. J. Soil Sci. 65:531-541.

Lowe, L.E. and Hinds, A.A. 1983. The mineralization of nitrogen and sulfur from particle-size separates of Gleysolic soils. Can. J. Soil Sci. 63:761-766.

Lowe, L.E. and Milne, I.H. 1979. The copper status of soils and forage in the Vanderhoof-Fort Fraser area of British Columbia. Can. J. Soil Sci. 59:325-327.

Lowe, L.E., Sasaki, A., and Krouse, H.R. 1971. Variations of sulfur 34:sulfur 32 ratios in soil fractions in western Canada. Can. J. Soil Sci. 51:129-131.

Luttmerding, H.A. 1971. Soil survey of the Alta Lake area. Mimeo. B.C. Min. Agric., Soils Div., Kelowna, B.C. 26 pp. (portion $92 \mathrm{~J} / 1,3$; map not included; 1:15 840).

"Luttmerding, H.A. 1980a. Soils of the Langley-Vancouver Map area. B.C. Soil Survey Report No. 15. Vol. 1. Soil map mosaics and legend, Lower Fraser Valley. RAB Bull. No. 18. B.C. Min. of Environ., Assessment and Planning Div., Victoria, B.C. 40 pp. (92 G/S; 1:25 000). 
*Luttmerding, H.A. 1980b. Soils of the Langley-Vancouver Map area. B.C. Soil Survey Report No. 15. Vol. 2. Soil map, mosaics and legend, Southern Sunshine Coast and Southern Coast Mountains. RAB Bull. No. 18. B.C. Min. Envir., Assessment and Planning Div., Victoria, B.C. 19 pp. (92 G/S; $1: 50$ 000).

*Luttmerding, H.A. 1981a. Soils of the Langley-Vancouver Map area. B.C. Soil Survey Report No. 15. Vol. 3 Description of the soils. RAB Bull. No. 18. B.C. Min. Envir., Assessment and Planning Div., Victoria, B.C. 227 pp. (92 G/S; map not included).

*Luttmerding, H.A. 1981b. Soils of the Langley-Vancouver Map area. B.C. Soil Survey Report No. 15. Vol. 6 Technical data soil profile descriptions and analytical data. RAB Bull. No. 18. B.C. Min. Envir., Assessment and Planning Div., Victoria, B.C. 345 pp. (92 G/S; map not included).

*Luttmerding, H.A. 1984. Soils of the Langley-Vancouver Map area. B.C. Soil Survey Report No. 15. Vol. 5 Agriculture Soil Management Groups. RAB Bull. No. 18. B.C. Min. Envir., Assessment and Planning Div., Victoria, B.C. 104 pp. (92 G/S; maps not included).

*Luttmerding, H.A. and Sprout, P.N. 1967. Soil Survey of Agassiz area. Lower Fraser Valley Soil Survey Prelim. Report No. 8. B.C. Min. Agric., Kelowna, B.C. 112 pp. (portions 92 H/4,5,6; 1:24 000; map not included).

Maas, E.F. 1963. The effect of seed spacing and nitrogen levels on the size of Netted Gem potatoes. Amer. Potato J. 40:133-136.

Maas, E.F. 1968. Nitrogen deficiency of potatoes on organic soil. Amer. Potato J. 45:379-382.

Maas, E.F. 1972. The organic soils of Vancouver Island. Mimeo. Agric. Can., Research Br., Agassiz, B.C. 135 pp.

Majak, W., McDiarmid, R.E., van Ryswyk, A.L., Broersma, K. and Bonin, S.G. 1979a. Alkaloid levels in reed canarygrass grown on wet meadows in British Columbia. J. Range Manage. 32:322-326.

Majak, W., McDiarmid, R.E., Powell, T.W., van Ryswyk, A.L., Stout, D.G., Williams, R.J. and Tucker, R.E. 1979b. Relationships between alkaloids in reed canarygrass (Phalaris arundinaceae), soil moisture and nitrogen fertility. Plant, Cell and Environ. 2:335-340.

Marshall, J.R. 1969. The climate of the east Kootenay region, pp. 33-45 in Lands of the East Kootenay: their characteristics and capability for agriculture and forestry, G.G. Runka (compiler). Mimeo. Report to B.C. Soil Capability for Agriculture and Forestry Committee from a cooperative interim report as part of the Canada Land Inventory Program, B.C. Min. of Agriculture, Victoria, B.C. 180 pp. ( $\mathrm{S}$ of $5115 \mathrm{~N}, \mathrm{E}$ of $11630 \mathrm{~W}$ )

Mathur, S.P. 1988. The use of copper for slowing down the biochemical oxidation and resultant subsidence of cultivated Organic soils, pp. 61-70 in Organic soils and horizons. Proc. 11th B.C. soil science workshop, Feb. 19-20, 1987, Vancouver, B.C. B.C. Min. Agric. and Fish., Victoria, B.C. 213 pp. 
Mathur, S.P. and Levesque, M.P. 1988. A revised agricultural capability rating scheme for organic soils in Canada, pp. 1-13 in Organic soils and horizons. Proc. 11th B.C. soil science workshop, Feb. 19-20, 1987, Vancouver, B.C. B.C. Min. Agric. and Fish., Victoria, B.C. 213 pp.

Maynard, D.E. 1988. Peatland inventory of British Columbia. (Open file 1988-73 maps, 1:250 000 not included). B.C. Min. Energy, Mines and Petroleum Resources, Mineral Resources Div., Geol. Survey Br., Victoria, B.C. 73 pp. (103 F; one example map included).

Maynard, D.G. and Bomke, A.A. 1980. The response of a grass-legume sward to poultry manure. Can. J. Soil Sci. 60:451-459.

McLean, A., Nicholson, H.H. and van Ryswyk, A.L. 1963. Growth, productivity and chemical composition of a sub-alpine meadow in interior British Columbia. J. Range Manage. 16:(5):235-240.

Meidinger, D. and Lewis, T. 1983. Biogeoclimatic zones and subzones of the Fort Nelson timber supply area, British Columbia. Northern fire ecology project. Mimeo. B.C. Min. Forests, Research Br., Victoria. 53 pp.

"Meidinger, D., Lewis, T. and Kowall, R. 1986. Biogeoclimatic zones and subzones of the northern portion of the Mackenzie timber supply area, British Columbia. Northern Fire Ecology Project. Mimeo. B.C. Min. Forests, Research Br., Victoria, B.C. 44 pp.

Miltimore, J.E., Mason, J.L. and Ashby, D.L. 1970. Copper, zinc, managanese and iron variation in five feeds for ruminants. Can. J. Anim. Sci. 50:293-300.

Miltimore, J.E., van Ryswyk, A.L., Pringle, W.L., Chapman, F.M. and Kalnin, C.M. 1975. Selenium concentration in British Columbia forages, grains and processed feeds. Can. J. Animal Sci. 55:101-111.

"Moon, D.E. and Brierly, J.A. 1988. Land resource inventory of Mill and Woodfibre creeks, British Columbia. B.C. Soil Survey Report No. 84-01. Land Resource Centre Contr. No. 83-62. Agric. Can., Research Br., Ottawa, Ont. 64 pp. (portion 92 G/11; Soil 1:15 840).

*Moon, D.E. and Selby, C.J. 1988. Land resource inventory of the Power River watershed, British Columbia. B.C. Soil Survey Report No. 64. Land Resource Research Centre Contr. No. 84-29. Agric. Can., Research Br., Ottawa, Ont. 145 pp. (portion 92 L/SW; Soil 1:15 840).

National Academy of Sciences-National Research Council (NAS-NRC) $1976 . \quad$ Nutrient requirements of beef cattle. Washington, D.C.

National Wetlands Working Group, Canada Committee on Ecological Land Classification(NWWG). 1986. Canada's wetlands: Maps of Wetland Regions and Distribution in Canada. Envir. Can., Lands Dir., Ottawa, Ont. 121 pp (2 maps 1:7 500 000, expanded legend).

National Wetlands Working Group, Canada Committee on Ecological Land Classification. 1987. The Canada wetland classification system. Provisional edition. Ecological Land Classification Series No. 21. Land Conservation Branch, Canadian Wildlife Service, Environment Canada, Ottawa, Canada. 18 pp. 
National Wetlands Working Group. 1988. Wetlands in Canada. Ecological Land Classification Series, No. 24. Sustainable Development Branch, Environment Canada, Ottawa, Ontario, and Polyscience Publications Inc., Montreal, Quebec. 452 pp.

Olson, B.M. and Lowe, L.E. 1990a. Effects of intensive vegetable production on chemical properties and nutrient mineralization of a British Columbia humisol. Can. J. Soil Sci: 70:445-460.

Olson, B.M. and Lowe, L.E. 1990b. Effects of intensive vegetable production on the hydrolyzable carbon, nitrogen and sulphur of a British Columbia humisol. Can. J. Soil Sci: 70:621-628.

Parasher, C.D. and Lowe, L.E. 1970. Isolation of clay-size organo-mineral complexes from soils of the Lower Fraser Valley. Can. J. Soil Sci. 50:403-407.

Paul, C.L. and de Vries, J. 1979a. Prediction of soil strength from hydrologic and mechanical properties. Can. J. Soil Sci. 59:301-311.

Paul, C.L. and de Vries, J. 1979b. Effect of soil water status and strength on trafficability. Can. J. Soil Sci. 59: 313-324.

Paul, C.L. and de Vries, J. 1983a. Soil trafficability in spring. 1. Simulation of the drainage process. Can. J. Soil Sci. 63: 15-26.

Paul, C.L. and de Vries, J. 1983b. Soil trafficability in spring. 2. Prediction and the effect of subsurface drainage. Can. J. Soil Sci. 63: 27-35.

Pojar, J. Klinka, K. and Meidinger, D.V. 1987. Biogeoclimatic ecosystem classification in British Columbia. Forest Ecology and Management, 22:119-154.

*Pojar, J., Trowbridge, R. and Lewis, T. 1983. Biogeoclimatic zones of the Cassiar timber supply area, Northwestern British Columbia. Mimeo. B.C. Min. Forests, Prince Rupert Forest Region, Research Sec., Smithers, B.C. 49 pp.

Pringle, W.L. and van Ryswyk, A.L. 1965. Response of water sedge in the growth room to fertilizer and temperature treatments. Can. J. Plant. Sci. 45:60-66.

Pringle, W.L. and van Ryswyk, A.L. 1968. Carry-over effects of high fertilizer rates on native sedge bog vegetation in interior British Columbia. Can. J. Plant Sci. 48:49-55.

Roberts, A. 1984. Guide to wetland ecosystems of the sub-boreal spruce subzone (SBSa) Cariboo forest region, British Columbia. Mimeo. B.C. Min. Forests, Williams Lake, B.C. 47 pp. (Appendix).

Rubec, C.D.A., Lynch-Stewart, P., Wickware, G.M. and Kessel-Taylor, I. 1988. Wetland utilization in Canada in Wetlands of Canada. Chap. 10, pp 379-412. Ecological Land Classification Series, No. 24. Sustainable Development Branch, Environment Canada, Ottawa, Ontario, and Polyscience Publications Inc., Montreal, Quebec. 452 pp.

"Runka, G.G. 1972. Soil resources of the Smithers - Hazelton area. Mimeo. Interim Report. B.C. Min. Agric., Soil Survey Div., Kelowna, B.C. 233 pp. (93 L/SE, L/N, M/SW; 1:126 720). 
8. Literature

*Runka, G.G. and Lewis, T. 1981. Preliminary wetland managers manual Cariboo resource management region. APD Tech. Paper No. 5. B.C. Min. Envir., Victoria, B.C. 113 pp.

*Ryder, J.M. 1984. Terrain inventory for the Stikine-Iskut area. Tech. Report No. 11. B.C. Min. Envir., Surveys and Resource Mapping Br., Victoria, B.C. 85 pp. (map not included; 104 F,G; portion $104 \mathrm{~B}, \mathrm{H})$.

Safo, E.Y. and Lowe, L.E. 1973. Manganese status of some Fraser Valley soils. Can. J. Soil Sci. 53:95-101.

Schaefer, D.G. 1978. Climate, pp. 3-10 in The soil landscapes of British Columbia, K.W.G. Valentine et al. (eds.). B.C. Min. Envir., Victoria, B.C. 197 pp.

Selby, C.J. 1983. Soil and vegetation relationship of coastal peatlands, pp. 31-37 in Report of activities on peatland research. Mimeo. Agric. Can., Research Br., Land Resources Research Inst., Cont. No. 83-02. Ottawa, Ont. 71 pp.

Selby, C.J. and Moon, D.E. 1988. A hydrologic model controlling wetland formation, pp.71-89 in Organic soils and horizons. Proc. 11th B.C. soil science workshop, Feb. 19-20, 1987, Vancouver, B.C. B.C. Min. Agric. and Fish., Victoria, B.C. 213 pp.

Sparks Companies Inc./KenAgra Management Services Ltd. (Sparks/KenAgra). 1992. British Columbia Beef Industry Review. An independent assessment and alternative direction commissioned by B.C. Ministry of Agriculture, Fisheries and Food, Victoria, B.C. 367 pp.

Sprout, P.N. and Kelley, C.C. 1960. Soil Survey of the North Okanagan Valley. Mimeo Interim Report. B.C. Dept. of Agriculture, Kelowna, B.C. 75 pp. (Portion 82 L /2, 3, 6, 7, 11, 10; 1:31 680; 4 maps not included).

*Sprout, P.N. and Kelley, C.C. 1963. Soil Survey of the Ashcroft-Savona area Thompson River Valley, British Columbia. Mimeo. Interim Report. B.C. Min. Agric., Kelowna, B.C. 99 pp. (portion 92 I/10,11,14,15; 1:31 680; 2 maps not included).

*Sprout, P.N. and Kelley, C.C. 1964. Soil survey of the Kettle River Valley in the Boundary District of British Columbia. B.C. Soil Survey Report No. 9. B.C. Min. Agric. and Agric. Can., Research Br., Queen's Printer, Ottawa, Ont. 111 pp. (portion 82 E/1,2,7-10; 1:63 360).

Steen, O.A. and Roberts, A.L. 1988. Guide to wetland ecosystems of the Very Dry Montane Interior Douglas-fir Subzone Eastern Fraser Plateau Variant (IDFb2) in the Cariboo Forest Region. B.C. Land Manage. Report No. 55. B.C. Min. Forests and Lands. 101 pp.

Talisman Land Resource Consultants, Vancouver, B.C. 1989. British Columbia beef industry study: a statistical profile. Prepared for B.C. Min. Forests, Victoria, B.C. 80 pp (Tables, Appendices).

Talisman Land Resource Consultants, Vancouver, B.C. 1991. Methane Inventory for Landforms in British Columbia. Carried out by W.A. Price as Appendix III, 27 pp. in An inventory and analysis of control measures for methane for British Columbia. Prepared by B.H. Levelton and Associates, Richmond, B.C. for B.C. Min. Environ., Air Management Br. (R.J. Williams, Supervisor), Victoria, B.C. 139 pp. (Appendices). 
Tarnocai, C. 1980. Canadian Wetland Registry, pp. 9-38 in Canadian Wetlands, C.D.A. Rubec and F.C. Pollet (eds.). Proc. Workshop on Canadian wetlands. Ecological Land Classification Series No. 12. Envir. Can., Lands Dir., Ottawa, Ont. 90 pp.

Tarnocai, C. and Schuppli, P.A. 1987. Sedimentary peat in Canadian peatlands, pp. 25-37 in Wetlands/Peatlands, C.D.A. Rubec and R.P. Overend (eds.). Proc. Symposium $19 \overline{87}$ Wetlands/peatlands, Edmonton, Alta. Ottawa, Ont. 704 pp.

Telford, J. 1991. Cariboo agriculture. Cariboo Cattlemen's Assoc., Can. Empl. and Immigr. Com. and B.C. Min. Agric., Fish. and Food. 21 pp.

Terasmae, J. 1977. Postglacial history of Canadian muskeg. pp. 9-30 in Muskeg and the Northern Environment in Canada, N.W. Radforth and C.O. Brawner (eds.). Proceedings, 15th Muskeg Research Conference, 1973, Edmonton, Alta. Muskeg Subcommittee of the National Research Council, Assoc. Committee on Geotechnical Research. Univ. of Toronto Press, Toronto, Ont. 399 pp.

*Valentine, K.W.G. 1971a. Soils of the Tofino-Ucluelet lowland of British Columbia. B.C. Soil Survey Report No. 11. Agric. Can., Research Br., Vancouver, B.C. 29 pp. (portion 102 F/SW; 1:50 000).

"Valentine, K.W.G. 1971b. Soils of the Fort Nelson area of British Columbia. B.C. Soil Survey Report No. 12. Agric. Can., Research Br., Vancouver, B.C. 60 pp. (94 J/NE; 1:126 720).

"Valentine, K.W.G. and Schori, A. 1980. Soils of the Lac La Hache-Clinton area, British Columbia. B.C. Soil Survey Report No. 25. Land Resource Research Inst. Contr. No. LLR1 63. Agric. Can., Research Br., Ottawa, Ont. 118 pp. (92 P/W; 1:125 000).

*Valentine, K.W.G., Watt, W. and Bedwany, A.L. 1987. Soils of the Taseko Lakes area, British Columbia. B.C. Soil Survey Report No. 36. Land Resource Research Centre Contr. No. 85-35. Agric. Can., Research Br., Ottawa, Ont. 131 pp. (92 0).

van Dalfsen, B. 1989. Wetland meadow development. B.C. Min. Agric. and Fish., Soils and Engin. Br., Abbotsford, B.C. Engineer. Notes. Order No. 222.500-1 4 pp.

"van Ryswyk, A.L. 1969. Forest and alpine soils of South-Central British Columbia. Mimeo. Ph.D. thesis, Washington State Univ., Dept. of Agronomy. Pullman, WA, USA. 178 pp.

van Ryswyk, A.L. 1983. Organic soils and water management, pp. 239-242 in Soil degradation in British Columbia. Proc. 8th B.C. soil science workshop, Feb. 17-18, Harrison Hot Springs, B.C. B.C. Min. Agric. and Food, Victoria, B.C. 273 pp.

van Ryswyk, A.L. 1988. Wetland management: Cariboo-Chilcotin, pp. 90-105 in Organic soils and horizons. Proc. 11th B.C. soil science workshop, Feb. 19-20, 1987, Vancouver, B.C. B.C. Min. Agric. and Fish., Victoria, B.C. 213 pp.

van Ryswyk, A.L., Hubbard, W.A. and Miltimore, J.E. 1973. Beef production potential and chemical composition of fertilized and unfertilized sedge hays grown on an Organic soil of interior British Columbia. Can. J. Anim. Sci. 53:181-186. 
van Ryswyk, A.L., Pringle, W.L. and Neufeld, J.H. 1974. Response of reed canary grass grown on ten British Columbia Organic soils to N, P, K and lime. Can. J. Soil Sci. 54:273-285.

"van Vliet, L.J.P., Green, A.J. and Kenney, E.A. 1987. Soils of the Gulf Islands of British Columbia. Vol. 1. Soils of Saltspring Island. B.C. Soil Survey Report No. 43. Land Resource Research Centre Contr. No. 84-6. Agric. Can., Research Br., Ottawa, Ont. 136 pp. (portion 92 B/NW; 1:20 000).

*van Vliet, L.J.P., Kenney, E.A. and Green, A.J. 1991. Soils of the Gulf Islands of British Columbia. Vol. 5. Soils of Sidney, James, Moresby, Portland and lesser islands. B.C. Soil Survey Report No. 43. Land Resource Research Centre Contr. No. 87-31. Agric. Can., Research Br., Ottawa, Ont. 123 pp. (portion $92 \mathrm{~B} / 11 ; 1: 20000$ ).

"Vold, T., Maxwell, R. and Hardy, R. 1977. Biophysical soil resources and land evaluation of the northeast coal study area. Vol. 1 and 2. B.C. Min. Envir., Resource Analysis Br., Victoria, B.C. Vol. 168 pp., Vol. 2 Appendices. (93 I/9-16, portions $93 \mathrm{~J} / 9$, 93 P/1-12).

Wahl, H.E., Fraser, D.B., Harvey, R.C and Maxwell, J.B. 1987. Climate of Yukon. Climatological Studies No. 40. Environment Canada, Atmospheric Services, Ottawa. 323 pp.

"Walmsley, M.E. and Lavkulich, L.M. 1973. In situ measurement of dissolved materials as an indicator of organic terrain type. Can. J. Soil Sci. 53:231-236.

Weir, T.R. 1964. Ranching in the southern interior plateau of British Columbia. Memoir 4 (Revised Edition) Geographical Branch, Dept. of Mines and Tech. Surveys. Queen's Printer, Ottawa, Ont. 165 pp.

"Wiken, E.B. and Farstad, L. 1973a. A soil resource and land use survey of the East Moberly Lake Indian Reserve No. 169. Report No. 281 and 282, respectively. Agric. Can., Research Br., Vancouver, B.C. 23 pp. (portion 93 P/13E; 1:50 700).

"Wiken, E.B. and Farstad, L. 1973b. A soil resource and land use survey of the West Moberly Lake Indian Reserve No. 168A. Report No. 282. Agric. Can., Research Br., Vancouver, B.C. 23 pp. (portion $93 \mathrm{P} / 13 \mathrm{~W} ; 1: 50700$ ).

*Wittneben, U. 1969. Soils of the East Kootenay, pp. 17-32 in Lands of the East Kootenay: their characteristics and capability for agriculture and forestry, G.G. Runka (compiler). Mimeo. Report to B.C. Soil Capability for Agriculture and Forestry Committee from a cooperative interim report as part of the Canada Land Inventory Program. B.C. Min. Agric., Victoria, B.C. 180 pp. (S of $5115 \mathrm{~N}$, E of 11630W; 1:1 311500$)$.

"Wittneben, U. 1980. Soil resources of the Lardeau map area. B.C. Soil Survey Report No. 27. RAB Bull. No. 15. B.C. Min. Envir., Resource Analysis Br., Kelowna, B.C. 209 pp. (82 K).

"Wittneben, U. 1984. Soils of the Hazelton map area. B.C. Soil Survey Report No. 47. B.C. Min. Envir. Tech. Report No. 7. B.C. Min. Envir., Surveys and Resource Mapping Br., Kelowna, B.C. 88 pp. (93 M/N, SE). 
"Wittneben, U. 1986. Soils of the Okanagan and Similkameen Valleys. B.C. Soil Survey Report No. 52. B.C. Min. Envir. Tech. Report No. 18. B.C. Min. Envir., Surveys and Resource Mapping Br., Victoria, B.C. 229 pp. ( $4900 \mathrm{~N}$ to $5000 \mathrm{~N}$ centering on 11930W; 1:20 000; map not included).

*Wittneben, U. and Sprout, P.N. 1971. Soil survey of the Creston area. Mimeo. Interim Report of the Creston Valley soil survey. B.C. Min. Agric., Kelowna, B.C. 93 pp. (portion 82 F/SE; 1:31 680; map not included).

Wood, R.C. 1981. Agriculture capability of Burns Bog. Mimeo. B.C. Min. Agric. and Food, Agric. Soils Br. and B.C. Agric. Land Com., Burnaby, B.C. 21 pp. (1:45 700 approx.; map in text).

Wood, R.C. 1983. Organic soil subsidence, pp. 122-131 in Soil degradation in British Columbia. Proc. 8th B.C. soil science workshop, Feb.17-18, 1983, Harrison Hot Springs, B.C. B.C. Min. of Agric. and Food, Victoria, B.C. 273 pp.

"Young, G. and Fenger, M. 1992. Soils of the Ashcroft area. B.C. Soil Survey Report No. 26. B.C. Min. Envir. and Parks Tech. Rep. No. 23. B.C. Min. Envir. and Parks, Surveys and Resource Mapping Br., Victoria, B.C. 245 pp. (92 I).

Zoltai, S.C. 1988. Wetland environments and classification, in Wetlands of Canada, Chap. 1:1-26. NWWG. Wetlands of Canada. Ecological Land Classification Series, No. 24. Sustainable Development Branch, Environment Canada, Ottawa, Ontario, and Polyscience Publications Inc., Montreal, Quebec. $452 \mathrm{pp}$. 
APPENDIX 9.1

\author{
Canadian System of Soil \\ Classification for Cryosolic, \\ Gleysolic and Organic Soil Orders
}

exerpted from

Agriculture Canada Expert Committee on Soil Survey (ACESS). 1987, pp. 63-65, 69-70, 82-84, respectively. The Canadian system of soil classification.

Agriculture Canada Publication, 1646, 2nd edition. Can. Govt. Pub. Centre, Supply and Services, Ottawa, 164 pp. 


\section{Chapter 6 CRYOSOLIC ORDER}

\section{Great Group}

Turbic Cryosol

Static Cryosol

Organic Cryosol

\section{Subgroup}

Orthic Turbic Cryosol O.TC

Brunisolic Turbic Cryosol BR.TC

Regosolic Turbic Cryosol R.TC

Gleysolic Turbic Cryosol GL.TC

\author{
Orthic Static Cryosol O.SC \\ Brunisolic Static Cryosol BR.SC \\ Regosolic Static Cryosol R.SC \\ Gleysolic Static Cryosol GL.SC
}

\author{
Fibric Organic Cryosol FI.OC \\ Mesic Organic Cryosol ME.OC \\ Humic Organic Cryosol HU.OC \\ Terric Fibric Organic Cryosol TFI.OC \\ Terric Mesic Organic Cryosol TME.OC \\ Terric Humic Organic Cryosol THU.OC \\ Glacic Organic Cryosol GC.OC
}

A diagrammatic representation of profiles of some subgroups of the Cryosolic order is shown in Fig. 28. A common horizon sequence is given for each subgroup; diagnostic horizons are underlined and some other commonly occurring horizons are listed. The subgroups include soils having horizon sequences different from those shown.

Soils of the Cryosolic order occupy much of the northern third of Canada where permafrost remains close to the surface of both mineral and organic deposits. Cryosolic soils predominate north of the tree line, are common in the subarctic forest area in fine textured soils, and extend into the Boreal Forest in some organic materials and into some alpine areas of mountainous regions. Cryoturbation of these soils is common, and it may be indicated by patterned ground features such as sorted and nonsorted nets, circles, polygons, stripes, and earth hummocks.

Cryosolic soils are formed in either mineral or organic materials that have permafrost either within $1 \mathrm{~m}$ of the surface or within $2 \mathrm{~m}$ if more than onethird of the pedon has been strongly cryoturbated, as indicated by disrupted, mixed, or broken horizons. They have a mean annual temperature below $0^{\circ} \mathrm{C}$. Differentiation of Cryosolic soils from soils of other orders involves either determining or estimating the depth to permafrost, which is a difficult task near the southern boundary of permafrost.

The Cryosolic order is divided into three great groups: Turbic Cryosol, Static Cryosol, and Organic Cryosol based on the degree of cryoturbation and the nature of soil material, mineral or organic, as indicated below.

\section{Cryosolic Order}

\begin{tabular}{|c|c|c|}
\hline Turbic Cryosol & Static Cryosol & Organic Cryosol \\
\hline Mineral soil & Mineral soil & Organic soil material \\
\hline Marked cryoturbation & No marked cryoturbation & Permafrost within $1 \mathrm{~m}$ of surface \\
\hline Usually patterned ground & Permafrost within $1 \mathrm{~m}$ of surface & \\
\hline Permafrost within $2 \mathrm{~m}$ of surface & & \\
\hline
\end{tabular}



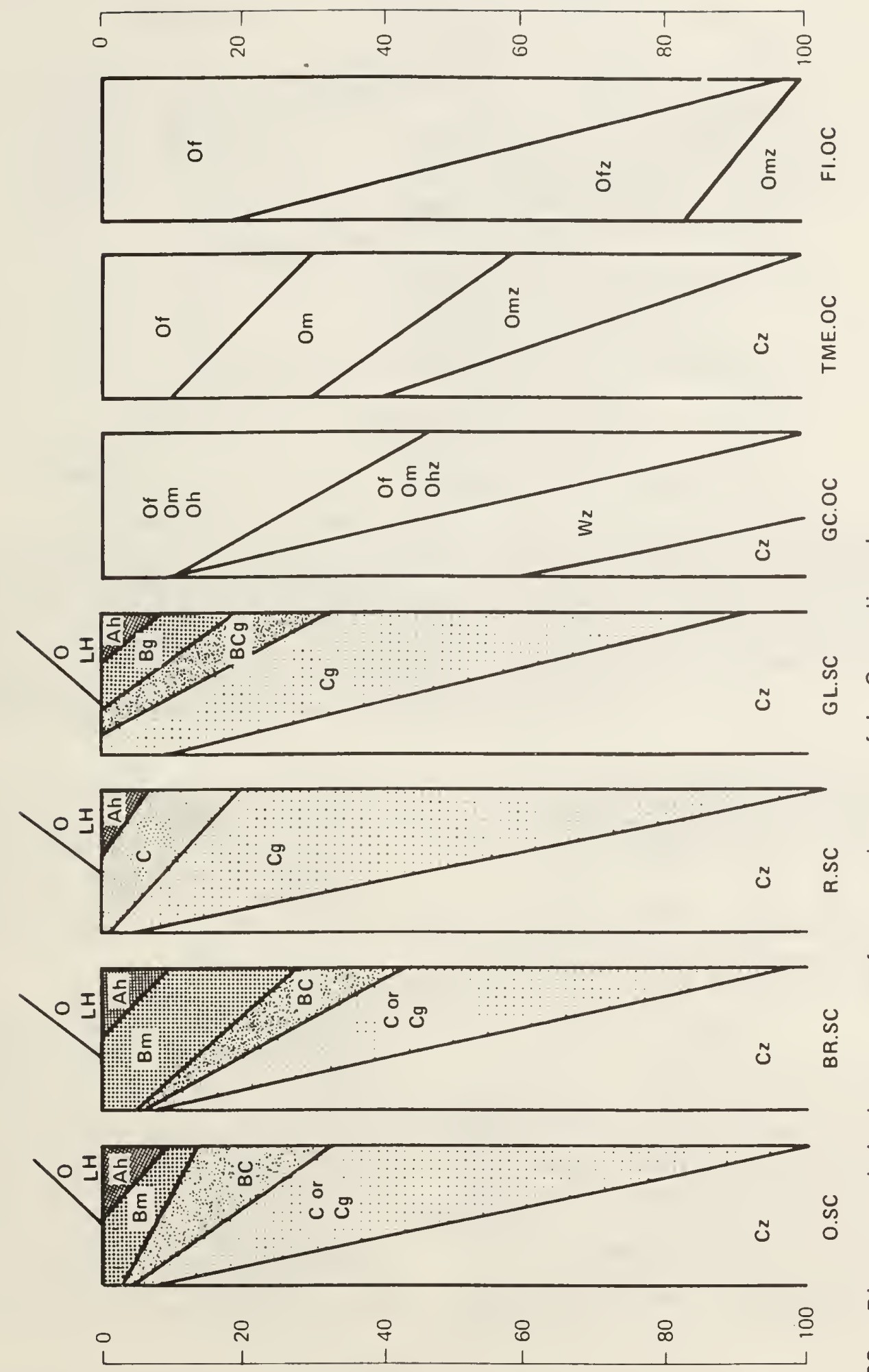

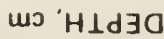

$\stackrel{\infty}{\sim}$

वंن 


\section{O.TC}
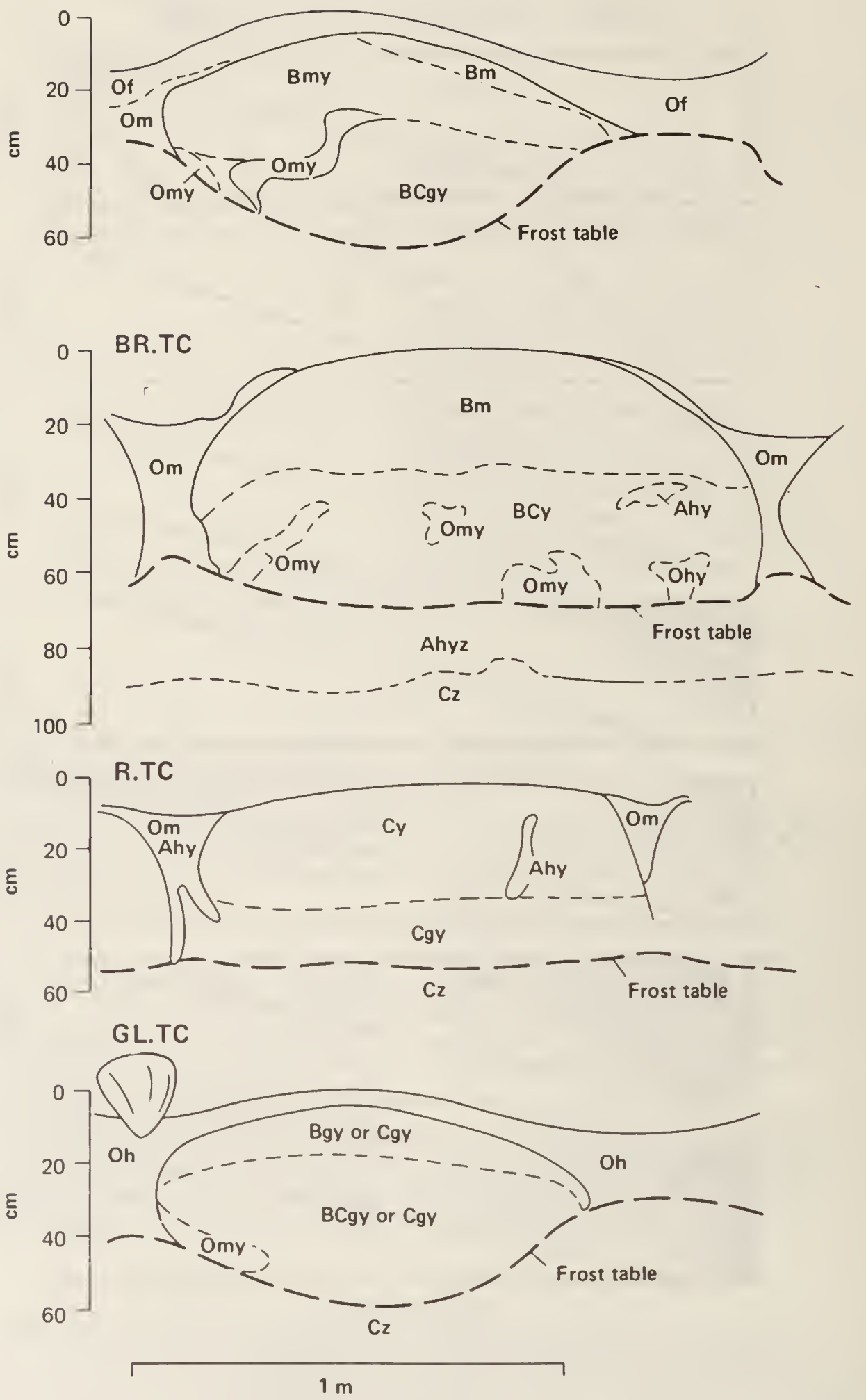

Fig. 28. Diagrammatic horizon pattern of some subgroups of the Cryosolic order. 


\section{Chapter 7 GLEYSOLIC ORDER}

\author{
Great Group \\ Luvic Gleysol
}

Humic Gleysol

Gleysol

\section{Subgroup}

Solonetzic Luvic Gleysol SZ.LG

Fragic Luvic Gleysol FR.LG

Humic Luvic Gleysol HU.LG

Fera Luvic Gleysol FE.LG

Orthic Luvic Gleysol O.LG

Solonetzic Humic Gleysol SZ.HG

Fera Humic Gleysol FE.HG

Orthic Humic Gleysol O.HG

Rego Humic Gleysol R.HG

\author{
Solonetzic Gleysol SZ.G \\ Fera Gleysol FE.G \\ Orthic Gleysol O.G \\ Rego Gleysol R.G
}

Note: The great groups and subgroups are arranged in the order in which they are keyed out. For example. if a Gleysolic soil has a Btg horizon it is classified as a Luvic Gleysol, regardless of whether or not it has any of the following: Ah. Bn, Bgf, or fragipan. The Luvic Gleysol is the first great group keyed out. Similarly, at the subgroup level, if a Luvic Gleysol has a solonetzic B horizon it is classified as a Solonetzic Luvic Gleysol, regardless of whether or not it has any of the following: fragipan, $\mathrm{Ah}$, or Bgf. In essence, any class at the great group or subgroup level as listed does not have the diagnostic properties of classes listed above it. For example, a Rego Gleysol does not have any of the following: a B horizon as defined for Orthic Gleysol, a Bgf horizon, or a solonetzic B horizon.

A diagrammatic representation of profiles of some subgroups of the Gleysolic order is shown in Fig. 29. A common horizon sequence is given for each subgroup; diagnostic horizons are underlined and some other commonly occurring horizons are listed. The subgroups include soils with horizon sequences different from those shown.

Gleysolic soils are defined on the basis of color and mottling, which are considered to indicate the influence of periodic or sustained reducing conditions during their genesis. The criteria that follow apply to all horizons except Ah, Ap, and Ae. However, if the Ae horizon is thicker than $20 \mathrm{~cm}$ and its lower boundary is more than 60 $\mathrm{cm}$ below the mineral soil surface, the criteria do apply to the Ae. In addition, if the Ah or Ap horizon is thicker than $50 \mathrm{~cm}$, the color criteria apply to the mineral horizon immediately below. Apart from these exceptions the criteria are as follows: In Gleysolic soils the upper boundary of a horizon or subhorizon (within $50 \mathrm{~cm}$ of the mineral surface) is at least $10 \mathrm{~cm}$ thick and has moist colors, as follows:

1. For all but red soil material (hue of 5YR or redder and color fades slowly on dithionite treatment).

a. Dominant chromas of 1 or less or hues bluer than $10 Y$ with or without mottles, or

b. Dominant chromas of 2 or less in hues of 10YR and 7.5YR accompanied by prominent mottles $\mathrm{Imm}$ or larger in cross section and occupying at least $2 \%$ of the exposed, unsmeared $10 \mathrm{~cm}$ layer, or c. Dominant chromas of 3 or less in hues yellower than IOYR accompanied by prominent mottles $1 \mathrm{~mm}$ or larger in cross section and occupying at least $2 \%$ of the exposed, unsmeared $10 \mathrm{~cm}$ layer.

2. For red soil materials (hues of $5 Y R$ or redder and color fades slowly on dithionite treatment).

a. Distinct or prominent mottles at least $1 \mathrm{~mm}$ in diameter occupy at least $2 \%$ of the exposed, unsmeared $10 \mathrm{~cm}$ layer.

Soils of the Gleysolic order have properties that indicate prolonged periods of intermittent or continuous saturation with water and reducing conditions during their genesis. Saturation with water may be due either to a high ground water table or to temporary accumulation of water above a relatively impermeable layer, or to both. In contrast, soils saturated periodically with aerated water or saturated for prolonged cold periods, which restricts biological activity without developing properties associated with reducing conditions, are not classified as Gleysols.

Gleysolic soils are associated with a number of different water regimes that may change during the genesis of the soil. They commonly have peraquic or aquic regimes, but some have aqueous regimes and others are now rarely, if ever, saturated with water. Saturated soils presumably had aquic regimes and were under reducing conditions in the past, but drainage, isostatic uplift, or other factors resulted in changed water regimes. 


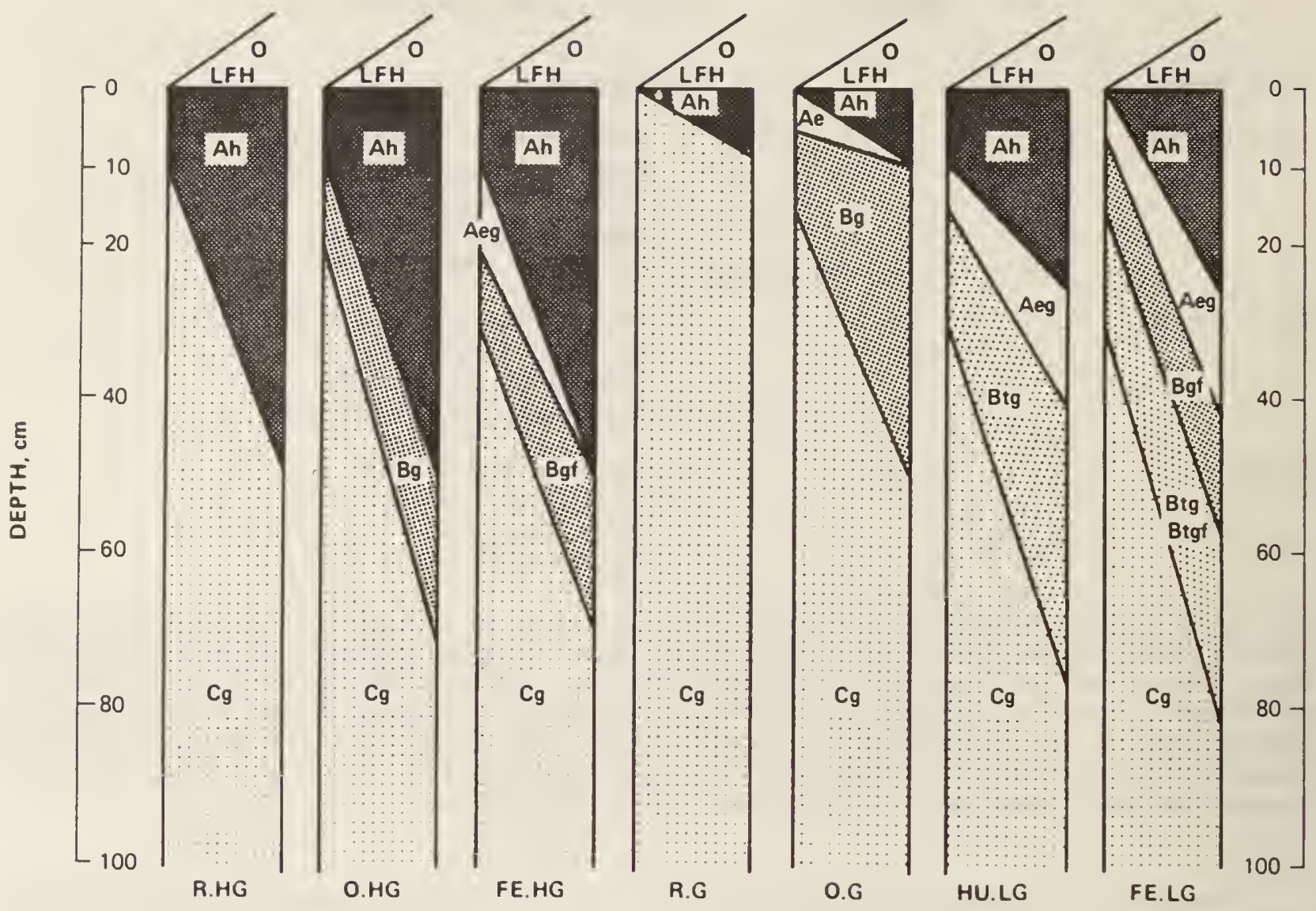

Fig. 29. Diagrammatic horizon pattern of some subgroups of the Gleysolic order.

Gleysolic Order

\begin{tabular}{lll}
\hline Luvic Gleysol & Humic Gleysol & Gleysol \\
\cline { 3 - 4 } $\begin{array}{c}\text { A Btg horizon } \\
\begin{array}{c}\text { Usually an Ahe or } \\
\text { an Aeg horizon }\end{array}\end{array}$ & $\begin{array}{c}\text { Ah horizon at least } \\
10 \mathrm{~cm} \text { thick }\end{array}$ & $\begin{array}{c}\text { No Ah horizon or } \\
\text { an Ah horizon } \\
<10 \mathrm{~cm} \text { thick }\end{array}$ \\
\hline
\end{tabular}




\section{Chapter 9 ORGANIC ORDER}

\section{Great Group}

Fibrisol

Mesisol

Humisol

Folisol

A diagrammatic representation of the depth relationships of tiers and of Typic and Terric subgroups of Organic soils is shown in Fig. 31. Diagrammatic sketches of profiles of some subgroups of the Organic order are shown in Figs. $32 \mathrm{~A}$ and $32 \mathrm{~B}$. A common horizon sequence is given for each subgroup; diagnostic horizons or layers are underlined, and some other commonly occurring horizons are listed. The subgroups include soils having horizon sequences different from those shown.

Soils of the Organic order are composed largely of organic materials. They include most of the soils commonly known as peat, muck, or bog soils. Most Organic soils are saturated with water for prolonged periods. They occur widely in poorly and very poorly drained depressions and level areas in regions of subhumid to perhumid climate and are derived from vegetation that grows in such sites. However, one group of Organic soils (Folisols) consists of upland (folic) organic materials, generally of forest origin. These Folisols are well to imperfertly drained, although they may become saturated after rainfall or snowmelt.

\section{Subgroup}

Typic Fibrisol TY.F

Mesic Fibrisol ME.F

Humic Fibrisol HU.F

Limno Fibrisol LM.F

Cumulo Fibrisol CU.F

Terric Fibrisol T.F

Terric Mesic Fibrisol TME.F

Terric Humic Fibrisol THU.F

Hydric Fibrisol HY.F

Typic Mesisol TY.M

Fibric Mesisol FI.M

Humic Mesisol HU.M

Limno Mesisol LM.M

Cumulo Mesisol CU.M

Terric Mesisol T.M

Terric Fibric Mesisol TFI.M

Terric Humic Mesisol THU.M

Hydric Mesisol HY.M

Typic Humisol TY.H

Fibric Humisol FI.H

Mesic Humisol ME.H

Limno Humisol LM.H

Cumulo Humisol CU.H

Terric Humisol T.H

Terric Fibric Humisol TFI.H

Terric Mesic Humisol TME.H

Hydric Humisol HY.H

Hemic Folisol HE.FO

Humic Folisol HM.FO

Lignic Folisol LI.FO

Histic Folisol HI.FO

Organic soils contain $17 \%$ or more organic C (30\% organic matter) by weight and meet the following specifications.

For organic materials $(\mathrm{O})$ that are commonly saturated with water and consist mainly of mosses, sedges, or other hydrophytic vegetation the specifications are:

1. If the surface layer consists of fibric organic material with or without mesic or humic Op horizons thinner than $15 \mathrm{~cm}$, the organic material must extend to a depth of at least $60 \mathrm{~cm}$.

2. If the surface layer is mesic or humic, the organic material must extend to a depth of at least $40 \mathrm{~cm}$.

3. If a lithic contact occurs at a depth shallower than $40 \mathrm{~cm}$, the organic material must extend to a depth of at least $10 \mathrm{~cm}$. Mineral material less than $10 \mathrm{~cm}$ thick may overlie the lithic contact, but the organic material must be more than twice 


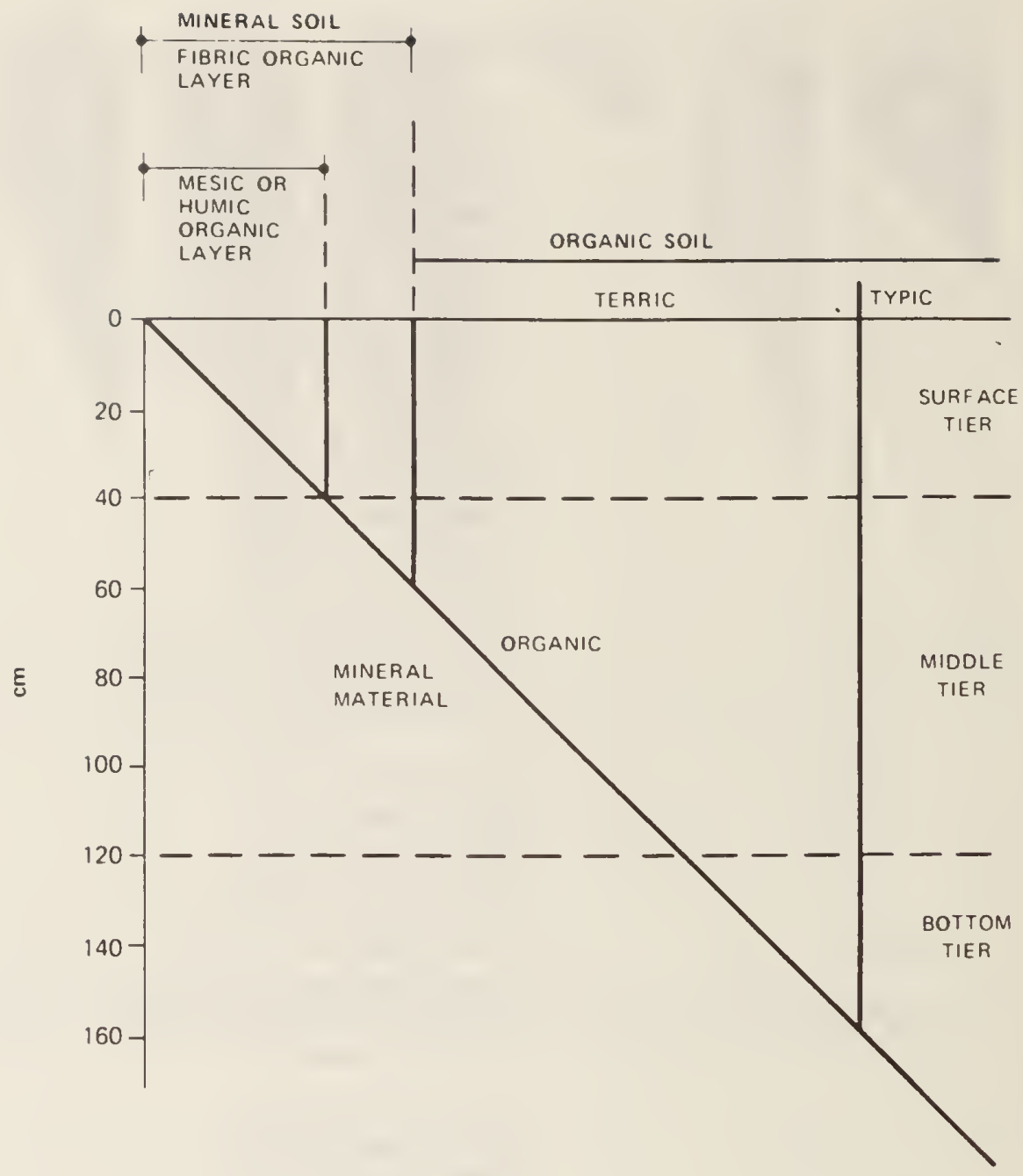

Fig. 31. Diagrammatic representation of depth relationships in the control section used to classify Fibrisol, Mesisol, and Humisol great groups.

Organic Order

\begin{tabular}{|c|c|c|c|}
\hline Fibrisol & Mesisol & Humisol & Folisol \\
\hline $\begin{array}{l}\text { Fibric middle } \\
\text { tier }\end{array}$ & $\begin{array}{l}\text { Mesic middle } \\
\text { tier }\end{array}$ & $\begin{array}{l}\text { Humic middle } \\
\text { tier }\end{array}$ & $\begin{array}{l}\text { Folic materials, rarely saturated with } \\
\text { water. }\end{array}$ \\
\hline
\end{tabular}




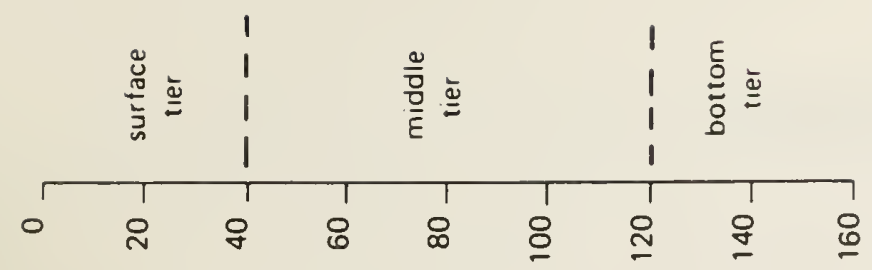

\begin{tabular}{lll|lll}
\hline & 1 & & 1 \\
1 & 5 & 3 & 1 \\
1 & 0 & 1 & 1
\end{tabular}

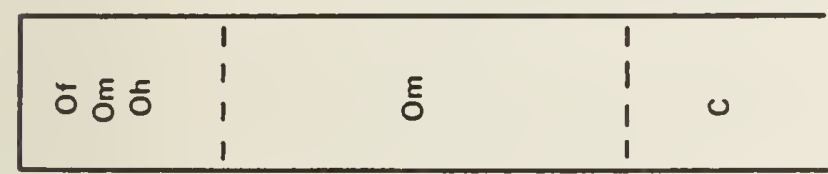

을

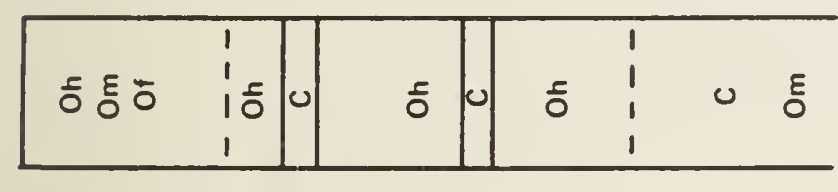

文

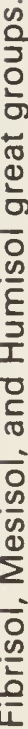
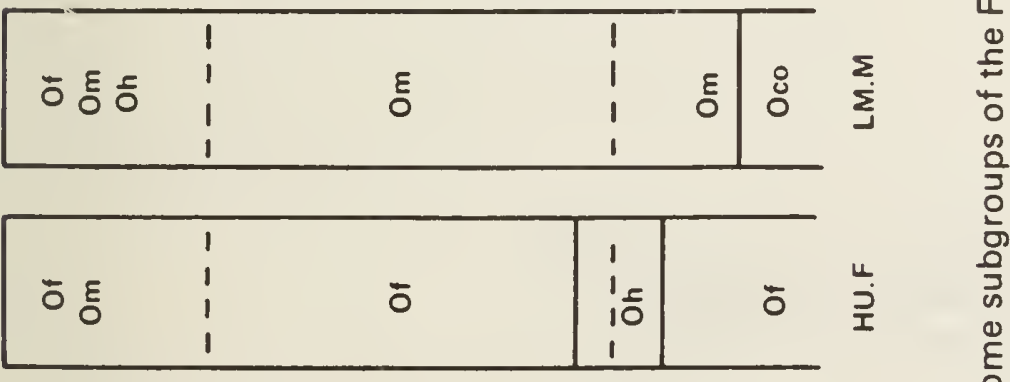

윽

은

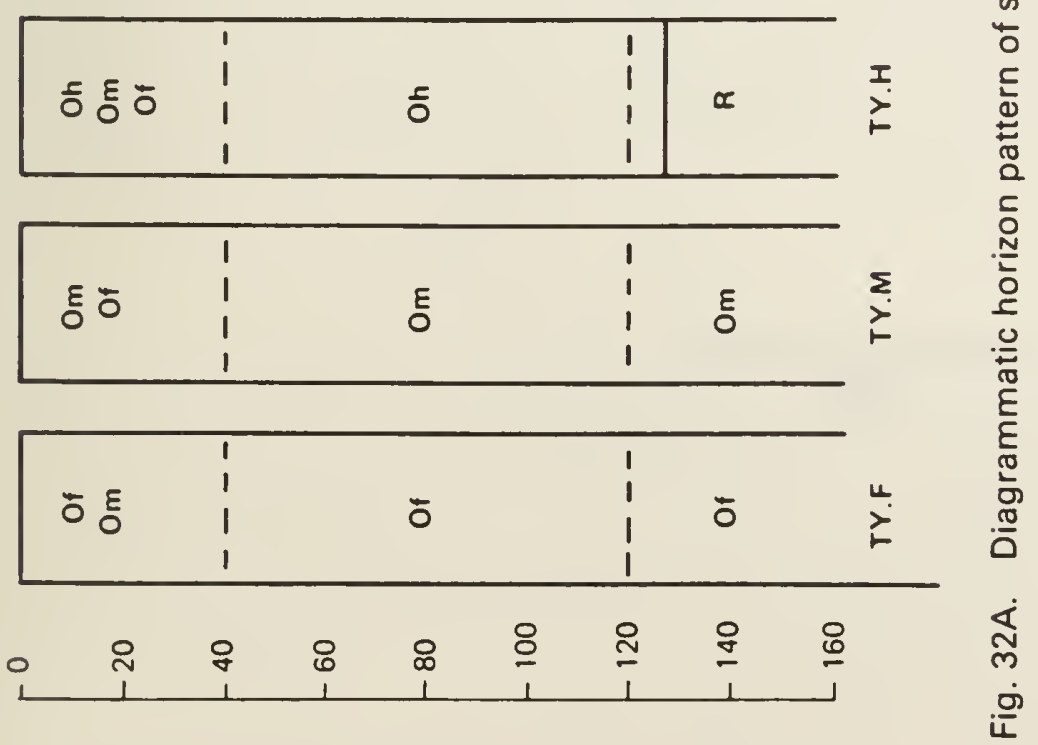

แว ' $H \perp d \exists O$ 


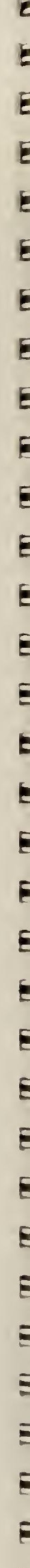




\title{
APPENDIX 9.2
}

The Canadian Wetland Classification System

excerpted from

\author{
National Wetlands Working Group \\ Canada Committee on \\ Ecological Land Classification
}

Provisional Edition

1987 


\section{The Canadian Wetland Classification System}

The development of a nationally applicable wetland classification system in Canada was first envisaged in 1973 with the completion of an organic terrain classification system by the National Committee on Forest Lands. Subsequently, Zoltai et al. (1975) proposed a four-level, hierarchical, ecologically based wetland classification system. This was refined for Canadian wetland classification by Tarnocai (1980). Jeglum et al. (1974) and Millar (1976) refined regional wetland classifications for Ontario and the Prairies. Other regional Canadian systems also exist, including that developed for Quebec by Couillard and Grondin (1986) and for British Columbia by Runka and Lewis (1981). The Canadian Wetland Classification System represents a synthesis of existing systems at the national level.

In its current form, this national classification system has been developed through the National Wetlands Working Group (NWWG) of the Canada Committee on Ecological Land Classification on the basis of the collective expertise and research of many wetland scientists across Canada. The NWWG, created in 1976, promotes holistic, ecologically based management, use, and conservation of Canadian wetlands. It acts through the informal support and contributions of federal, provincial, territorial, and non-government agencies.

The Canadian Wetland Classification System has not been fully applied and tested throughout Canada in all local and regional settings. As such, it remains "provisional" and subject to revision in future editions. Recently, it was used to form the basis of a national perspective on Canada's wetlands (National Wetlands Working Group 1986).

This classification system continues to evolve as new research is undertaken. The classification keys for the wetland forms will be refined based on their field application. In addition, the NWWG is developing a generalized key for wetland classes. Specific experience with the wording of wetland form and type descriptions will also govern future versions of this classification. Breakdown into more specific types for categories such as mosses and forbs may also occur.

A national field description and registry form for wetland ecosystems was developed by the NWWG (Tarnocai 1980). Subsequently, this field form was modified for computerized data entry. Entitled "Canadian Wetland Registry Input Document for Field Data", the form and a companion manual are available from the Land Resource Research Centre, Agriculture Canada, Ottawa. They permit the collection of standardized field data and the organization of descriptive information on the location, soils, hydrology, peat development, and physical and chemical properties of soil and water in Canadian wetlands.

\section{Bog wetland class}

A bog is a peatland, generally with the water table at or near the surface. The bog surface, which may be raised or level with the surrounding mineral soils and is thus generally acid and low in nutrients. The dominant materials are weakly to moderately decomposed Sphagnum and woody peat, underlain at times by sedge peat. The soils are mainly Fibrisols, Mesisols, and Organic Cryosols (permafrost soils.). Bogs may be treed or treeless, and they are usually covered with Sphagnum spp. and ericaceous shrubs. 


\section{Classification Key to Bog Wetland Forms}

1. Surface raised above surrounding terrain

2. Surface convex

3. Core frozen; abruptly domed; usually in fens

4. Over $1 \mathrm{~m}$ high, diameter up to $100 \mathrm{~m}$

4. Less than $1 \mathrm{~m}$ high, diameter up to $3 \mathrm{~m}$

Palsa Bog

3. Core not frozen

Peat Mound Bog

5. Convex surface small (1-3m diameter); occuring in fens

Mound Bog

5. Convex surface often extensive; not occuring in fens

Domed Bog

2. Surface flat to irregular

6. Core perennially frozen

7. Surface with network of polygonal fissures

8. Surface even

Polygonal Peat

8. Surface with high centres in a polygonal network

Plateau Bog

Lowland

Polygon Bog

7. Surface without polygonal fissures;

surface about $1 \mathrm{~m}$ above the surrounding fen

6. Core not frozen

9. Bogs generally teardrop-shaped

Peat Plateau

Bog

9. Bogs not teardrop-shaped; abundance of surface water

Northern

Plateau Bog

Atlantic

Plateau Bog

1. Surface not raised above surrounding terrain

10. Surface relatively level

11. With abrupt marginal peat walls

11. Without marginal peat walls

12. Adjacent to water bodies

13. Floating

13. Not floating

12. Not adjacent to water bodies

Collapse Scar Bog

Floating Bog

Shore Bog

14. Surface flat; topographically confined

15. Basin deposit; depth greatest in centre

15. Flat deposit; depth generally uniform

Basin Bog

Flat Bog

14. Surface flat to undulating, often appreciably sloping

16. Surface pattern of ridges and pools distinct

16. Surface pattern of pools usually absent; extensive

10. Surface not level; appreciably sloping

17. Core not frozen

17. Core perennially frozen

String Bog

Blanket Bog

Slope Bog

Veneer Bog 


\section{Fen Weltand Class}

A fen is a peatland with the water table usually at or just above the surface. The waters are mainly nutrient-rich and minerotrophic from mineral soils. The dominant materials are moderately to well decomposed sedge and/or brown moss peat of variable thickness. The soils are mainly Mesisols, Humisols, and Organic Cryosols. The vegetation consists predominantly of sedges, grasses, reeds and brown mosses with some shrubs and, at times, a sparse tree layer.

\section{Classification Key to Fen Wetland Forms}

1. Surface not raised above surrounding terrain except

in low hummocks and ridges

2. Surface pattern of ridges and depressions

3. Subarallel pattern of ridges and furrows

4. Broad pattern; often very extensive

5. Northern regions; lowland drainage; peat deep

Northern

5. Atlantic regions; mainly upland drainage; peat shallow

Ribbed Fen

Atlantic

Ribbed Fen

4. Narrow ladder-like pattern; along bog flanks

3. Reticulate pattern of ridges

Ladder Fen

Net Fen

2. Without pronounced surface pattern

6. Featureless, adjacent to water bodies

7. Floating

7. Not floating

8. Located in main channel or along banks of continuously flowing or semi-permanent streams

8. Located along shores of semi-permanent or permanent lakes

Floating Fen

Stream Fen

Shore Fen

6. Depressed thaw hollows with high-water content peat; not adjacent to water bodies

Collapse Scar Fen

1. Surface raised above surrounding terrain

9. Surface sloping appreciably

10. With frozen core

11. Mounds in patterned fen

Palsa Fen

11. Surface regular but sloping

Snowpatch Fen

10. Without frozen core

12. Water from underground discharge

12. Water from overland flow

13. Surface with parallel drainage-ways

Spring Fen

Feather Fen

13. Surface smooth or with irregular tracts

Slope Fen

9. Surface flat or depressional

14. Core perennially frozen, surface with network

of polygonal fissures

Lowland

Polygon Fen

14. Core not frozen, surface with network of pronounced surface pattern

15. Basin part of regional drainage system 
16. Occupying broad depressions or plains

16. Occupying well-defined, often eroded channels water
Horizontal Fen

Channel Fen

Basin Fen

\section{Marsh Weltand Class}

A marsh is a mineral wetland or a peatland that is periodically inundated by standing or slowly moving water. Surface water levels may fluctuate seasonally, with declining levels exposing drawdown zones of matted vegetation or mudflats. The waters are rich in nutrients, varying from fresh to highly saline. The substratum usually consists of mineral material, although occasionally it consists of well-decomposed peat. The soils are predominantly Gleysols, with some Humisols and Mesisols. Marshes characteristically show zonal or mosaic surface patterns composed of pools or channels interspersed with clumps of emergent sedges, grasses, rushes, and reeds, bordering grassy meadows and peripheral bands of shrubs or trees. Submerged and floating aquatics flourish where open water areas occur.

\section{Classification Key to Marsh Wetland Forms}

1. Influenced by tidal water

2. Water saline

3. In river estuaries or connecting bays where tidal flats, channels and pools are periodically inundated by water of varying salinity

4. Located above mean high-water levels; inundated only at highest tides and/or storm surges

Estuarine High

4. Located below mean high-water levels; frequently inundated

Estuarine Low

3. On marine terraces, flats embayments, or Marsh lagoons behind barrier beaches, remote from estuaries, where there is periodic inundation by tidal brackish or salt water, including salt spray

5. Located above mean high-water levels; inundated only at flood tides

Coastal High Marsh

5. Located below mean high-water levels

Coastal Low Marsh

2. Water fresh

Tidal

Freshwater Marsh

1. Not influenced by tidal water

6. Located in topographically defined catch basins or valleys

7. Associated with riverine or linear systems

8. Adjacent to, or flooded by, flowing water

9. Located on active fluvial floodplains 
adjacent to channels

Floodplain

Marsh

9. Not on fluvial floodplains

10. Occupying shorelines, bars, streambeds, or islands in continuously flowing water courses

10. Occupying abandoned glacial meltwater spillways, intermittent drainage courses, or open-ended, eroded channels

Stream Marsh

Channel Marsh

8. Located on river deltas

11. Unrestricted water circulation, open connections to river channels and lakes, seasonally inundated

11. Restricted water circulation, inundated only during infrequent high river flows or wind tides

7. Associated with defined basins having poorly integrated surface drainage, fed by local runoff or groundwater

12. Located at the terminus of an internal drainage system, may be flat or concave in topographically low areas, no outflow

12. Located along an internal drainage system; surface or underground water passes through the basin

13. Shallow, gently sloping depressions that occur as natural swales or that occupy intervening areas between ridges or undulations on low-relief landforms

13. Sharply defined, bowl-shaped catch basin, usually located in high or intermediate topographic positions on moderate-to high-relief hummocky moraine, glaciolacustrine or glacio-fluvial landforms

Active Delta Marsh

Inactive Delta Marsh

Terminal Basin Marsh

Shallow Basin Marsh

6. Not located in topographically defined catch basins

14. Occupying groundwater discharge sites, usually on or at the base of slopes

14. Occupying the shores of semi-permanent or permanent lakes, receiving water from lake flooding or surface runoff

Seepage Track Marsh

Shore Marsh 


\section{Swamp Wetland Class}

A swamp is a mineral wetland or a peatland with standing water or water gently flowing through pools or channels. The water table is usually at or near the surface. There is pronounced internal water movement from the margin or other mineral sources; hence the waters are rich in nutrients. If peat is present, it is mainly well-decomposed wood, underlain at times by sedge peat. The associated soils are Meisols, Humisols, and Gleysols. The vegetation is characterized by a dense cover of deciduous or coniferous trees or shrubs, herbs, and some mosses.

\section{Classification Key to Swamp Wetland Forms}

1. Adjacent to water bodies

2. Located along banks of continuously slowing or semi-permanent streams

Stream Swamp

2. Located along shores of semi-permanent or permanent lakes

Shore Swamp

1. Not adjacent to permanent water bodies

3. In topographically defined basins

4. On perimeter of peatlands

Peat Margin

Swamp

4. Basin deposit; depth greatest in centre

Basin Swamp

3. Not in topographically defined basins

5. Acting as a water discharge area

6 . Flat deposit, depth generally uniform

Flat Swamp

6. Poorly drained area, associated with floodplains

Floodplain

Swamp

\section{Shallow Water Wetland Class}

Shallow water is characteristic of intermittently or permanently flooded or seasonally stable water regimes, featuring open expanses of standing or flowing water which are variously called ponds, pools, shallow lakes, oxbows, reaches, channels, or impoundments. Shallow water is distinguished from deep water by mid-summer water depths of less than $2 \mathrm{~m}$, and from other wetlands by summer open water zones occupying $75 \%$ or more of the wetland surface area.

Large open water areas (greater than 8ha), located within wetland complexes, should be classified separately as shallow water units, despite the area or extent of bordering vegetation zones. Periodic flooding may increase water depths, but during droughts, low flows, drainage, or intertidal periods, drawdown flats may be exposed.

Shallow water is distinguished from uplands and bordering wetland complexes by watereroded shorelines, or by the landward margins of mudflats, floating mats, emergents, or shrubs. In the open water zone, living vegetation, if present, is confined to submerged and floating aquatic plant forms. 


\section{Classification Key to Shallow Water Wetland Forms}

1. Inland; fresh to saline water bodies less than $2 \mathrm{~m}$ deep

2. Associated with riverine systems

3. Water continuously flowing in main water course

Stream Water

3. Water not continuously flowing

4. Intermittent flowing water to discontinuous surface flow, confined to glacio-fluvial, eroded spillways

4. Intermittent flow or overbank flooding, impounded behind levees or ridges of alluvial deposits

5. On river floodplains

Oxbow Water

5. On deltas

Delta Water

2. Not associated with riverine systems

6. Surface catchment in topographically defined basin

7. Basin not affected by permafrost

8. Basin at terminus of drainage system

Terminal Basin

8. Basin not at terminus, water passes through the basin

9. Shallow, gently sloping basin with relatively uniform depth

Shallow Basin

9. Relatively deep, bowl-shaped with moderately sloping sides

Water

7. Basin affected by permafrost

Kettle Water

10. Shallow basin with stable, steep shores

Tundra Pool

Water

10. Shallow basin with unstable, collapsing shores

Thermokarst

Water

6. Not in topographically defined catch basin, occupying the shallow shore zone of permanent open water bodies

Shore Water

1. Coastal, estuarine, or marine water bodies less than $2 \mathrm{~m}$ deep

11. Tidal water

12. Estuarine channels or bays periodically inundated by fresh and brackish water

Estuarine

Water

12. Coastal lagoons or bays primarily influenced by tidal action and marine salt water

Tidal Water

11. Non-tidal water

13. Fresh to brackish water bodies located above mean high-tide zone

Non-tidal

Water 


\section{APPENDIX 9.3}

Summary of British Columbia wetland distribution, $\mathrm{km}^{2}(\%)$ by $0100 \mathrm{~N} \times 0200 \mathrm{~W}$ map area, and by elevation category. 


\begin{tabular}{|c|c|c|c|c|c|c|c|c|c|c|c|c|}
\hline \multicolumn{3}{|l|}{ Map area } & \multirow{2}{*}{\multicolumn{2}{|c|}{$\begin{array}{l}\text { Wet } \\
1 \text { ar }\end{array}$}} & \multicolumn{4}{|c|}{ Elevation Category by } & \multicolumn{3}{|c|}{$100 \mathrm{~m}$ 1nterval } & \multirow{2}{*}{$\begin{array}{l}\text { Map } \\
\text { Area } \\
100 \%\end{array}$} \\
\hline Name & $\begin{array}{l}\text { NTS } \\
\text { Des1c } \\
\text { nat1c }\end{array}$ & & & & $0-3$ & $3-6$ & $6-9$ & $9-12$ & $12-15$ & $>15$ & Total & \\
\hline Penticton & 82 & E & $\begin{array}{l}16 \\
16 \\
16\end{array}$ & $\begin{array}{l}T \\
O \\
G\end{array}$ & $\begin{array}{r}18 \\
0 \\
18\end{array}$ & $\begin{array}{c}100(1) \\
2 \\
98(1)\end{array}$ & $\begin{array}{r}26 \\
2 \\
23\end{array}$ & $\begin{array}{l}29 \\
<1 \\
29\end{array}$ & $\begin{array}{r}20 \\
12 \\
7\end{array}$ & $\begin{array}{r}60 \\
4 \\
56\end{array}$ & $\begin{array}{c}253(2) \\
21 \\
231(1)\end{array}$ & $\begin{array}{c}16143 \\
"\end{array}$ \\
\hline Nelson & 82 & F & $\begin{array}{l}16 \\
16 \\
16\end{array}$ & $\begin{array}{l}T \\
O \\
G\end{array}$ & $\begin{array}{l}0 \\
0 \\
0\end{array}$ & $\begin{array}{r}78 \\
1 \\
77\end{array}$ & $\begin{array}{r}73 \\
6 \\
67\end{array}$ & $\begin{array}{r}10 \\
0 \\
10\end{array}$ & $\begin{array}{l}5 \\
1 \\
4\end{array}$ & $\begin{array}{r}10 \\
0 \\
10\end{array}$ & $\begin{array}{r}176 \\
8 \\
168\end{array}$ & $\begin{array}{c}16128 \\
" "\end{array}$ \\
\hline Fernle & 82 & $\underline{G}$ & $\begin{array}{l}13 \\
13 \\
13\end{array}$ & $\begin{array}{l}T \\
0 \\
G\end{array}$ & $\begin{array}{l}0 \\
0 \\
0\end{array}$ & $\begin{array}{r}52 \\
0 \\
52\end{array}$ & $\begin{array}{l}90(1) \\
0 \\
90(1)\end{array}$ & $\begin{array}{r}39 \\
4 \\
36\end{array}$ & $\begin{array}{r}18 \\
0 \\
18\end{array}$ & $\begin{array}{r}32 \\
0 \\
32\end{array}$ & $\begin{array}{c}230(2) \\
4 \\
227(2)\end{array}$ & $\begin{array}{c}13128 \\
" ~\end{array}$ \\
\hline Kananask1s L. & 82 & $\mathbf{J}$ & 9 & $\mathrm{~T}$ & 0 & 0 & 16 & 9 & $<1$ & 8 & 33 & 8904 \\
\hline Lardeau & 82 & $\mathrm{k}$ & $\begin{array}{l}16 \\
16 \\
16\end{array}$ & $\begin{array}{l}T \\
0 \\
G\end{array}$ & $\begin{array}{l}0 \\
0 \\
0\end{array}$ & $\begin{array}{l}3 \\
0 \\
3\end{array}$ & $\begin{array}{r}20 \\
0 \\
20\end{array}$ & $\begin{array}{l}2 \\
1 \\
1\end{array}$ & $\begin{array}{l}3 \\
0 \\
3\end{array}$ & $\begin{array}{l}0 \\
0 \\
0\end{array}$ & $\begin{array}{r}28 \\
1 \\
27\end{array}$ & $\begin{array}{c}15801 \\
" \\
"\end{array}$ \\
\hline Vernon & 82 & $\mathrm{~L}$ & $\begin{array}{l}16 \\
16 \\
16\end{array}$ & $\begin{array}{l}T \\
0 \\
G\end{array}$ & $\begin{array}{l}0 \\
0 \\
0\end{array}$ & $\begin{array}{c}196(1) \\
29 \\
167(1)\end{array}$ & $\begin{array}{r}46 \\
6 \\
40\end{array}$ & $\begin{array}{l}27 \\
11 \\
17\end{array}$ & $\begin{array}{r}23 \\
21 \\
2\end{array}$ & $\begin{array}{c}151(1) \\
22 \\
129(1)\end{array}$ & $\begin{array}{c}442(3) \\
88 \\
354(2)\end{array}$ & $\begin{array}{c}15772 \\
" 1\end{array}$ \\
\hline Seymour Arm & 82 & M & $\begin{array}{l}16 \\
16 \\
16\end{array}$ & $\begin{array}{l}\mathrm{T} \\
0 \\
\mathrm{G}\end{array}$ & $\begin{array}{l}0 \\
0 \\
0\end{array}$ & $\begin{array}{r}15 \\
14 \\
1\end{array}$ & $\begin{array}{r}39 \\
30 \\
9\end{array}$ & $\begin{array}{l}5 \\
4 \\
1\end{array}$ & $\begin{array}{l}11 \\
11 \\
<1\end{array}$ & $\begin{array}{r}71 \\
71 \\
0\end{array}$ & $\begin{array}{l}142(1) \\
131(1) \\
12\end{array}$ & $\begin{array}{c}15559 \\
" "\end{array}$ \\
\hline Golden & 82 & $\mathbf{N}$ & 13 & $\mathbf{T}$ & 0 & 0 & 6 & 48 & 9 & 1 & 64 & 12646 \\
\hline 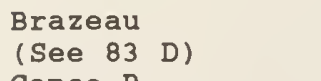 & 83 & C & 1 & $\mathbf{T}$ & 0 & 0 & 0 & 0 & 0 & 0 & 0 & 953 \\
\hline $\begin{array}{l}\text { Canoe R. } \\
\text { (McNaughton L. })^{6}\end{array}$ & 83 & $\mathrm{D}$ & $\begin{array}{r}16 \\
3 \\
3\end{array}$ & $\begin{array}{l}T \\
0 \\
G\end{array}$ & $\begin{array}{l}0 \\
0 \\
0\end{array}$ & $\begin{array}{r}<1 \\
0 \\
<1\end{array}$ & $\begin{array}{l}20 \\
18(1) \\
0\end{array}$ & $\begin{array}{l}8 \\
0 \\
0\end{array}$ & $\begin{array}{r}10 \\
4 \\
0\end{array}$ & $\begin{array}{r}13 \\
9 \\
0\end{array}$ & $\begin{array}{l}51 \\
31(1) \\
<1\end{array}$ & $\begin{array}{c}15186 \\
2826 \\
"\end{array}$ \\
\hline $\begin{array}{l}\text { Mt Robson } \\
\text { (See } 93 \mathrm{H} \\
\text { McBr1de) }\end{array}$ & 83 & $\mathrm{E}$ & $\begin{array}{l}3 \\
2 \\
2\end{array}$ & $\begin{array}{l}\mathrm{T} \\
0 \\
\mathrm{G}\end{array}$ & $\begin{array}{l}0 \\
0 \\
0\end{array}$ & $\begin{array}{l}0 \\
0 \\
0\end{array}$ & $\begin{array}{l}16 \\
16(2) \\
1\end{array}$ & $\begin{array}{l}0 \\
0 \\
0\end{array}$ & $\begin{array}{l}0 \\
0 \\
0\end{array}$ & $\begin{array}{l}0 \\
0 \\
0\end{array}$ & $\begin{array}{l}16 \\
16(2) \\
1\end{array}$ & $\begin{array}{l}2793 \\
934 \\
11\end{array}$ \\
\hline $\begin{array}{l}\text { Cape Flattery } \\
\text { (See } 92 \text { B, C } \\
\text { V1ctor } 1 \mathrm{a})^{6}\end{array}$ & 92 & B & $\begin{array}{l}6 \\
6 \\
6\end{array}$ & $\begin{array}{l}\mathrm{T} \\
0 \\
\mathrm{G}\end{array}$ & $\begin{array}{l}51 \\
14 \\
37(1)\end{array}$ & $\begin{array}{l}1 \\
1 \\
0\end{array}$ & $\begin{array}{l}0 \\
0 \\
0\end{array}$ & $\begin{array}{l}0 \\
0 \\
0\end{array}$ & $\begin{array}{l}0 \\
0 \\
0\end{array}$ & $\begin{array}{l}0 \\
0 \\
0\end{array}$ & $\begin{array}{l}52(1) \\
15 \\
37(1)\end{array}$ & $\begin{array}{l}3256 \\
" 1 \\
"\end{array}$ \\
\hline $\begin{array}{l}\text { Cape Flattery } \\
\text { (See } 92 \text { B, C } \\
\text { V1ctor } 1 \text { a) })^{6}\end{array}$ & 92 & c & $\begin{array}{l}5 \\
1 \\
1\end{array}$ & $\begin{array}{l}\mathrm{T} \\
0 \\
\mathrm{G}\end{array}$ & $\begin{array}{r}2 \\
<1 \\
0\end{array}$ & $\begin{array}{r}<1 \\
0 \\
0\end{array}$ & $\begin{array}{l}8 \\
0 \\
0\end{array}$ & $\begin{array}{l}0 \\
0 \\
0\end{array}$ & $\begin{array}{l}0 \\
0 \\
0\end{array}$ & $\begin{array}{l}0 \\
0 \\
0\end{array}$ & $\begin{array}{r}11 \\
<1 \\
0\end{array}$ & $\begin{array}{l}3716 \\
1020 \\
" 1\end{array}$ \\
\hline Nootka Sound & 92 & $E$ & 8 & $\mathrm{~T}$ & 6 & 0 & 0 & 0 & 0 & 0 & 0 & 6029 \\
\hline $\begin{array}{l}\text { Port Albern } 1 \\
\text { (Albern } 1)^{6}\end{array}$ & 92 & $\mathbf{E}$ & $\begin{array}{r}16 \\
9 \\
9\end{array}$ & $\begin{array}{l}T \\
0 \\
G\end{array}$ & $\begin{array}{r}153(1) \\
46(1) \\
107(2)\end{array}$ & $\begin{array}{r}1 \\
0 \\
<1\end{array}$ & $\begin{array}{l}0 \\
0 \\
0\end{array}$ & $\begin{array}{l}2 \\
2 \\
0\end{array}$ & $\begin{array}{l}0 \\
0 \\
0\end{array}$ & $\begin{array}{l}0 \\
0 \\
0\end{array}$ & $\begin{array}{r}155(1) \\
47(1) \\
107(2)\end{array}$ & $\begin{array}{r}13017 \\
5950 \\
"\end{array}$ \\
\hline Vancouver & 92 & G & $\begin{array}{l}16 \\
10 \\
10\end{array}$ & $\begin{array}{l}\mathrm{T} \\
\mathrm{O} \\
\mathrm{G}\end{array}$ & $\begin{array}{l}639(5) \\
134(2) \\
375(5)\end{array}$ & $\begin{array}{l}0 \\
0 \\
0\end{array}$ & $\begin{array}{l}0 \\
0 \\
0\end{array}$ & $\begin{array}{l}0 \\
0 \\
0\end{array}$ & $\begin{array}{l}0 \\
0 \\
0\end{array}$ & $\begin{array}{l}0 \\
0 \\
0\end{array}$ & $\begin{array}{l}639(5) \\
134(2) \\
375(5)\end{array}$ & $\begin{array}{r}13052 \\
7785 \\
" 1\end{array}$ \\
\hline Hope & 92 & $\mathrm{H}$ & $\begin{array}{l}16 \\
10 \\
10\end{array}$ & $\begin{array}{l}T \\
0 \\
G\end{array}$ & $\begin{array}{r}38 \\
7 \\
31\end{array}$ & $\begin{array}{l}1 \\
0 \\
0\end{array}$ & $\begin{array}{r}15 \\
3 \\
12\end{array}$ & $\begin{array}{r}24 \\
16 \\
8\end{array}$ & $\begin{array}{l}46 \\
28 \\
17\end{array}$ & $\begin{array}{r}155 \\
43 \\
113\end{array}$ & $\begin{array}{r}279(2) \\
96(1) \\
181(2)\end{array}$ & $\begin{array}{c}16081 \\
10065 \\
" 1\end{array}$ \\
\hline Ashcroft & 92 & I & $\begin{array}{l}16 \\
16 \\
16\end{array}$ & $\begin{array}{l}T \\
0 \\
G\end{array}$ & $\begin{array}{l}0 \\
0 \\
0\end{array}$ & $\begin{array}{r}<1 \\
0 \\
<1\end{array}$ & $\begin{array}{l}2 \\
0 \\
2\end{array}$ & $\begin{array}{l}5 \\
5 \\
0\end{array}$ & $\begin{array}{r}20 \\
20 \\
0\end{array}$ & $\begin{array}{l}9 \\
9 \\
0\end{array}$ & $\begin{array}{r}36 \\
34 \\
2\end{array}$ & $\begin{array}{c}15848 \\
" "\end{array}$ \\
\hline
\end{tabular}




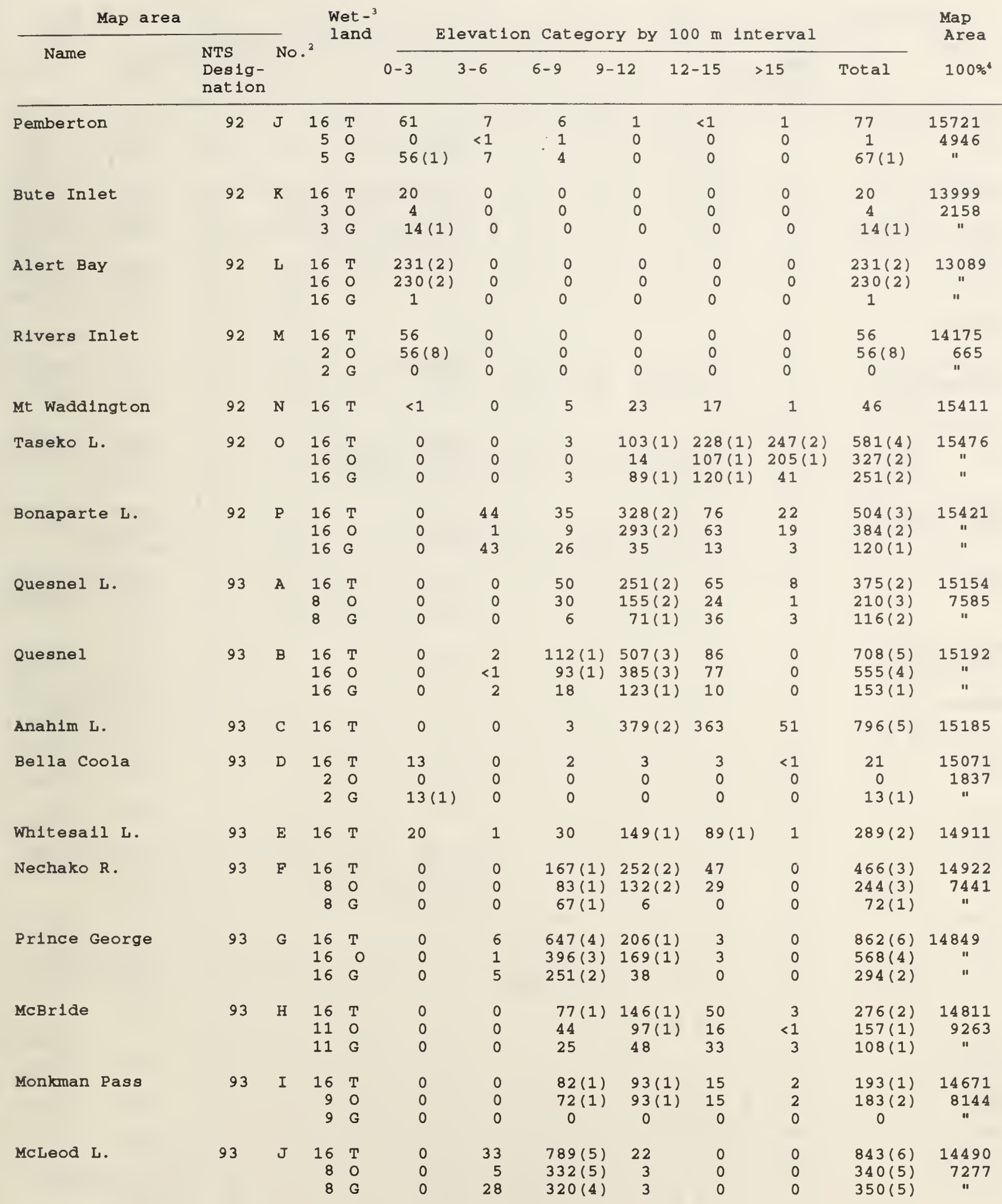




\begin{tabular}{|c|c|c|c|c|c|c|c|c|c|c|c|c|}
\hline \multicolumn{3}{|c|}{ Map area } & \multirow{2}{*}{\multicolumn{2}{|c|}{$\begin{array}{l}\text { Wet }-3 \\
\text { land }\end{array}$}} & \multicolumn{2}{|c|}{ Elevat1on } & \multicolumn{4}{|c|}{ Category by $100 \mathrm{~m}$ interval } & \multirow{2}{*}{\multicolumn{2}{|c|}{$\begin{array}{l}\text { Map } \\
\text { Area } \\
100 \%\end{array}$}} \\
\hline Name & $\begin{array}{l}\text { NTS } \\
\text { Des1g- } \\
\text { nat1on }\end{array}$ & & & & $0-3$ & $3-6$ & $6-9$ & $9-12$ & $12-15$ & $>15$ & & \\
\hline Fort Fraser & 93 & $\mathrm{R}$ & $\begin{array}{l}16 \\
12 \\
12\end{array}$ & $\begin{array}{l}T \\
O \\
G\end{array}$ & $\begin{array}{l}0 \\
0 \\
0\end{array}$ & $\begin{array}{l}0 \\
0 \\
0\end{array}$ & $\begin{array}{r}374(3) \\
226(2) \\
84(1)\end{array}$ & $\begin{array}{c}124(1) \\
84(1) \\
11\end{array}$ & $\begin{array}{l}7 \\
7 \\
0\end{array}$ & $\begin{array}{l}1 \\
1 \\
0\end{array}$ & $\begin{array}{r}506(3) \\
318(3) \\
95(1)\end{array}$ & $\begin{array}{c}14496 \\
10907 \\
" 1\end{array}$ \\
\hline Sm1thers & 93 & L & $\begin{array}{l}16 \\
12 \\
12\end{array}$ & $\begin{array}{l}T \\
0 \\
G\end{array}$ & $\begin{array}{l}0 \\
0 \\
0\end{array}$ & $\begin{array}{r}33 \\
1 \\
32\end{array}$ & $\begin{array}{r}202(1) \\
78(1) \\
117(1)\end{array}$ & $\begin{array}{l}251(2) \\
140(1) \\
101(1)\end{array}$ & $\begin{array}{c}138(1) \\
36 \\
66(1)\end{array}$ & $\begin{array}{r}25 \\
2 \\
23\end{array}$ & $\begin{array}{l}621(4) \\
256(2) \\
340(3)\end{array}$ & $\begin{array}{c}14491 \\
10859 \\
\text { " }\end{array}$ \\
\hline Hazelton & 93 & 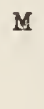 & $\begin{array}{r}16 \\
4 \\
4\end{array}$ & $\begin{array}{l}T \\
O \\
G\end{array}$ & $\begin{array}{l}0 \\
0 \\
0\end{array}$ & $\begin{array}{r}28 \\
16 \\
9\end{array}$ & $\begin{array}{r}57 \\
0 \\
2\end{array}$ & $\begin{array}{c}87(1) \\
14 \\
7\end{array}$ & $\begin{array}{l}35 \\
15 \\
10\end{array}$ & $\begin{array}{l}0 \\
0 \\
0\end{array}$ & $\begin{array}{r}206(1) \\
45(1) \\
29(1)\end{array}$ & $\begin{array}{c}14072 \\
3540 \\
" 1\end{array}$ \\
\hline Manson R. & 93 & $N$ & 16 & $\mathrm{~T}$ & 0 & 0 & 2 & 1 & 0 & 0 & 3 & 14072 \\
\hline $\begin{array}{l}\text { P1ne Рass } \\
(\text { MacKenz1e) }\end{array}$ & 93 & 0 & $\begin{array}{r}16 \\
4 \\
4\end{array}$ & $\begin{array}{l}T \\
O \\
G\end{array}$ & $\begin{array}{l}0 \\
0 \\
0\end{array}$ & $\begin{array}{l}0 \\
0 \\
0\end{array}$ & $\begin{array}{c}86(1) \\
0 \\
0\end{array}$ & $\begin{array}{r}16 \\
9 \\
1\end{array}$ & $\begin{array}{l}41 \\
2 \\
39(1)\end{array}$ & $\begin{array}{l}0 \\
0 \\
0\end{array}$ & $\begin{array}{l}143(1) \\
11 \\
40(1)\end{array}$ & $\begin{array}{c}14072 \\
3496 \\
"\end{array}$ \\
\hline Dawson Creek & 93 & $\mathrm{P}$ & $\begin{array}{l}16 \\
16 \\
16\end{array}$ & $\begin{array}{l}\mathrm{T} \\
\mathbf{O} \\
\mathrm{G}\end{array}$ & $\begin{array}{l}0 \\
0 \\
0\end{array}$ & $\begin{array}{l}0 \\
0 \\
0\end{array}$ & $\begin{array}{l}543(4) \\
187(1) \\
356(3)\end{array}$ & $\begin{array}{l}345(2) \\
125(1) \\
221(2)\end{array}$ & $\begin{array}{l}0 \\
0 \\
0\end{array}$ & $\begin{array}{l}0 \\
0 \\
0\end{array}$ & $\begin{array}{l}888(6) \\
312(2) \\
577(4)\end{array}$ & $\begin{array}{c}14072 \\
" \\
"\end{array}$ \\
\hline $\begin{array}{l}\text { Charlie L. } \\
\text { (Ft St John) }\end{array}$ & 94 & A & $\begin{array}{l}16 \\
16 \\
16\end{array}$ & $\begin{array}{l}T \\
O \\
G\end{array}$ & $\begin{array}{l}0 \\
0 \\
0\end{array}$ & $\begin{array}{l}4 \\
4 \\
0\end{array}$ & $\begin{array}{l}3428(25) \\
1552(11) \\
1876(14)\end{array}$ & $\begin{array}{l}0 \\
0 \\
0\end{array}$ & $\begin{array}{l}0 \\
0 \\
0\end{array}$ & $\begin{array}{l}0 \\
0 \\
0\end{array}$ & $\begin{array}{l}3432(25) \\
1556(11) \\
1876(14)\end{array}$ & $\begin{array}{c}13716 \\
"\end{array}$ \\
\hline Halfway R. & 94 & B & $\begin{array}{r}16 \\
8 \\
8\end{array}$ & $\begin{array}{l}T \\
O \\
G\end{array}$ & $\begin{array}{l}0 \\
0 \\
0\end{array}$ & $\begin{array}{l}0 \\
0 \\
0\end{array}$ & $\begin{array}{l}246(2) \\
21 \\
225(3)\end{array}$ & $\begin{array}{c}179(1) \\
5 \\
174(3)\end{array}$ & $\begin{array}{r}14 \\
2 \\
12\end{array}$ & $\begin{array}{l}0 \\
0 \\
0\end{array}$ & $\begin{array}{c}439(3) \\
28 \\
411(6)\end{array}$ & $\begin{array}{c}13716 \\
6858 \\
\text { " }\end{array}$ \\
\hline $\begin{array}{l}\text { Melinka R. } \\
\text { (Ft Grahame) }^{6}\end{array}$ & 94 & C & 16 & $\mathrm{~T}$ & 0 & 0 & $129(1)$ & 0 & 0 & 0 & $129(1)$ & 13716 \\
\hline McConnell Cr. & 94 & $\mathrm{D}$ & 16 & $\mathbf{T}$ & 0 & 0 & 3 & 26 & 43 & 0 & $71(1)$ & 13716 \\
\hline Toodoggone R. & 94 & $E$ & 16 & $\mathrm{~T}$ & 0 & 0 & 8 & $83(1)$ & 52 & 1 & $145(1)$ & 13355 \\
\hline Ware & 94 & $\mathbf{F}$ & 16 & $\mathrm{~T}$ & 0 & 0 & $78(1)$ & 46 & 0 & 0 & $125(1)$ & 13355 \\
\hline Trutch & 94 & G & 16 & $\mathrm{~T}$ & 0 & 2 & $161(1)$ & $76(1)$ & 10 & 0 & $249(2)$ & 13355 \\
\hline Beaton R. & 94 & $\mathrm{H}$ & $\begin{array}{r}16 \\
8 \\
8\end{array}$ & $\begin{array}{l}T \\
0 \\
G\end{array}$ & $\begin{array}{l}0 \\
0 \\
0\end{array}$ & $\begin{array}{l}8 \\
0 \\
0\end{array}$ & $\begin{array}{l}4351(33) \\
1952(29) \\
2361(35)\end{array}$ & $\begin{array}{c}157(7) \\
0 \\
157(2)\end{array}$ & $\begin{array}{l}0 \\
0 \\
0\end{array}$ & $\begin{array}{l}0 \\
0 \\
0\end{array}$ & $\begin{array}{l}4516(34) \\
1952(29) \\
2518(37)\end{array}$ & $\begin{array}{c}13355 \\
6723 \\
11\end{array}$ \\
\hline Fontas R. & 94 & $I$ & 16 & $\mathrm{~T}$ & 0 & $8910(69)$ & $531(4)$ & 0 & 0 & 0 & $9440(73)$ & 12990 \\
\hline Fort Nelson & 94 & $\mathrm{~J}$ & $\begin{array}{r}16 \\
6 \\
6\end{array}$ & $\begin{array}{l}\mathrm{T} \\
0 \\
\mathrm{G}\end{array}$ & $\begin{array}{l}0 \\
0 \\
0\end{array}$ & $\begin{array}{c}3022(23) \\
2122(44) \\
244(5)\end{array}$ & $\begin{array}{r}133 \\
0 \\
5\end{array}$ & $\begin{array}{l}0 \\
0 \\
0\end{array}$ & $\begin{array}{l}0 \\
0 \\
0\end{array}$ & $\begin{array}{l}0 \\
0 \\
0\end{array}$ & $\begin{array}{c}3156(24) \\
2122(44) \\
249(5)\end{array}$ & $\begin{array}{c}12990 \\
4831 \\
"\end{array}$ \\
\hline Tuchod1 L. & 94 & $\mathrm{~K}$ & 16 & $\mathrm{~T}$ & 0 & 0 & 16 & 0 & 0 & 0 & 16 & 12990 \\
\hline Retch1ka R. & 94 & L & 16 & $\mathrm{~T}$ & 0 & 7 & 39 & 50 & 3 & 0 & $99(1)$ & 12990 \\
\hline Rabb1t R. & 94 & $\mathbf{M}$ & 16 & $\mathrm{~T}$ & 0 & 18 & 45 & 31 & 0 & 0 & $95(1)$ & 12620 \\
\hline Toad R. & 94 & $\mathbf{N}$ & 16 & $\mathrm{~T}$ & 0 & 48 & $151(1)$ & 0 & 0 & 0 & $199(2)$ & 12620 \\
\hline Maxham1sh L. & 94 & 0 & $\begin{array}{r}16 \\
8 \\
8\end{array}$ & $\begin{array}{l}\mathrm{T} \\
\mathrm{O} \\
\mathrm{G}\end{array}$ & $\begin{array}{l}4 \\
0 \\
0\end{array}$ & $\begin{array}{c}3408(27) \\
1649(26) \\
323(5)\end{array}$ & $\begin{array}{r}389(3) \\
223(4) \\
87(1)\end{array}$ & $\begin{array}{l}0 \\
0 \\
0\end{array}$ & $\begin{array}{l}0 \\
0 \\
0\end{array}$ & $\begin{array}{l}0 \\
0 \\
0\end{array}$ & $\begin{array}{c}3801(30) \\
1871(29) \\
410(6)\end{array}$ & $\begin{array}{c}12620 \\
6357 \\
" 1\end{array}$ \\
\hline
\end{tabular}




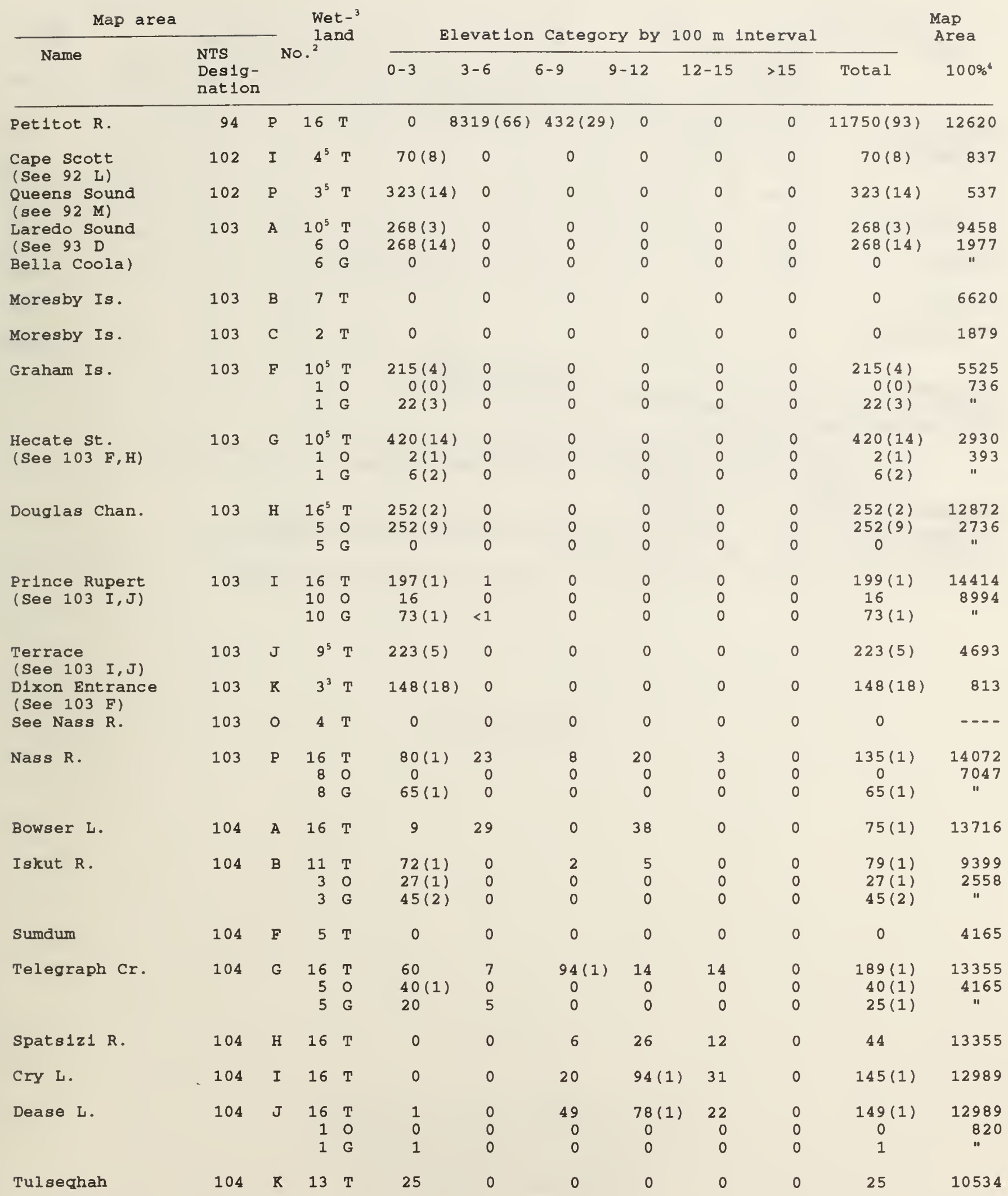




\begin{tabular}{|c|c|c|c|c|c|c|c|c|c|c|c|c|}
\hline \multicolumn{3}{|l|}{ Map area } & \multirow{2}{*}{\multicolumn{2}{|c|}{$\begin{array}{l}\text { Wet }{ }^{3} \\
\text { land }\end{array}$}} & \multirow[b]{2}{*}{$0-3$} & evat1 & \multicolumn{4}{|c|}{ Category by $100 \mathrm{~m}$ 1nterval } & \multirow[b]{2}{*}{ Total } & \multirow{2}{*}{$\begin{array}{l}\text { Map } \\
\text { Area } \\
100 \%\end{array}$} \\
\hline Name & \multicolumn{2}{|l|}{$\begin{array}{l}\text { NTS } \\
\text { Des1g- } \\
\text { nat } 1 \text { on }\end{array}$} & & & & $3-6$ & $6-9$ & $9-12$ & $12-15$ & $>15$ & & \\
\hline $\begin{array}{l}\text { See } 104 \mathrm{R} \\
\text { (Tulseqhah) }\end{array}$ & 104 & L & 1 & $\mathrm{~T}$ & 0 & 0 & 0 & 0 & 0 & 0 & 0 & 803 \\
\hline skagway & 104 & M & 10 & $\mathrm{~T}$ & 0 & 0 & 35 & 19 & 1 & 0 & $54(1)$ & 7870 \\
\hline Atlin & 104 & $\mathbf{N}$ & 16 & $\mathrm{~T}$ & 0 & 10 & 45 & 31 & 1 & 0 & $87(1)$ & 12620 \\
\hline Jennlngs $R$. & 104 & 0 & 16 & $\mathrm{~T}$ & 0 & 0 & $150(1)$ & $74(1)$ & 59 & 0 & $283(2)$ & 12620 \\
\hline McDame & 104 & P, & 16 & $\mathrm{~T}$ & 0 & 0 & $455(4)$ & $317(3)$ & 5 & 0 & $777(6)$ & 12620 \\
\hline Yakutat & 114 & 0 & 2 & $\mathrm{~T}$ & 0 & 0 & 0 & 0 & 0 & 0 & 0 & 1571 \\
\hline Tatshenshin1 R. & 114 & $\mathrm{P}$ & 12 & $\mathrm{~T}$ & 0 & 8 & 27 & 0 & 0 & 0 & 34 & 9436 \\
\hline
\end{tabular}

${ }^{1}$ Designation of $0100 \mathrm{~N} \times 0200 \mathrm{~W}$ map area (see F1gs. 1,8).

${ }^{2}$ Number of $0015 \mathrm{~N} \times 0030 \mathrm{~W}$ map areas. (See F1g. 1).

${ }^{3}$ Wetland Type (see F1gs. 2-7)

T - Total wetland 1ncluding swamp (marsh) from NTS map, and organlc and gleysollc soll wetland from Soll-CLI map sources.

O - Organ1c so1l wetland.

G - Gleysolic soll wetland.

'Rounded to nearest $1 \%, 1 . e .0 .500$ or greater, based on map area $(100 \%)$.

${ }^{5}$ Includes Organlc Coastal slope bog, deslgnated as organlc, but adjusted using Dendron (1985) data. See Table 1, F1g 2.

${ }^{6}$ Alternate name. Non-bracketed names are 1ndlcated on July 1991 NTS Index 2. 


\section{APPENDIX 9.4}

CLIMATE OF B.C.

reproduced from

Schaefer, D.G. 1978. Climate, pp. 3-10 in The soil landscapes of British Columbia,

K.W.G. Valentine et al. (eds.).

B.C. Ministry of Environment,

Victoria, B.C. 197 pp. 


\subsection{CLIMATE}

\section{D.G. Schaefer}

The climate of British Columbia varies enormously from place to place. On the macro-scale, climates associated with the major soil landscape regions (Part 3) are a product of geographical location and large scale topography. On the micro-scale, conditions at the earth's surface are modified by local physiographic factors such as slope, aspect and elevation. Micro-scale climates are also affected by vegetation and the condition of the soil itself through influences on the processes of evaporation and heat exchange.

The latitude of British Columbia places the province squarely in the zone of the westerly atmospheric circulation of the northern hemisphere. Its position on the western side of North America places it in proximity to the vast Pacific Ocean which is an immense reservoir of heat and moisture. The Pacific plays the dominant role in determining the climates of the province.

Innumerable winter storms born over the North Pacific Ocean develop rapidly, move in a northeasterly direction to the Gulf of Alaska and there weaken and die. Frontal systems which break away from the storm centres impinge upon the coastline and there face another major determinant of British Columbia climates; successive large-scale mountain barriers aligned in a northwest to southeast direction. Since these are roughly perpendicular to the mean winds aloft, they determine to a major extent the overall distribution of precipitation and the degree of dominance of Pacific air masses in relation to continental air masses in the various regions of the province. Weather systems carried by the prevailing westerly winds aloft drop considerable moisture as rain or, at higher elevations, as snow, when the air is forced up the west-facing slopes of Vancouver Island, the Queen Charlotte Islands and the Coast Mountains. The wettest climates of British Columbia are found in this zone. On the eastern slopes, the air descends and is heated by compression, causing the clouds to dissipate. The driest climates of the province lie in the valley bottoms in the lee of the massive coastal barrier. As the air again ascends the Monashee and Purcell Mountains, the Cariboo and Cassiar Ranges, and finally the Rocky Mountains, additional moisture is released with the heaviest precipitation falling on the westfacing slopes of each successive mountain barrier.

The mountain ranges are effective barriers to prevailing westerly winds, with particular emphasis on low-level moisture supply; they also block the westiward passage of frigid continental Arctic air masses which 
dominate the winter season east of the Rocky Mountains. While the Great Plains region of northeastern British Columbia lacks this protection, other parts of the province experience varying degrees of shielding from the onslaught of Arctic air, increasingly so as one moves from east to west and from north to south.

In summer, the prevailing westerlies weaken. The climate then comes under the dominance of the large, semi-permanent Pacific anti-cyclone or high pressure centre which expands northward, greatly diminishing the frequency and intensity of Pacific storms and coastal precipitation. In the interior, spring is a season of decreased precipitation. About June, precipitation again increases as an interplay of factors, which include high rates of insolation and late spring surges of cool unstable air, produces strengthened convective activity, resulting in showers and thundershowers. In addition, a number of so-called "cold low" storms normally cross the province en route to the Great Plains. By mid-summer, these normally decline as the Pacific anti-cyclone develops its dominance over western North America.

Having described some of the macro-scale climatic controls at work over British Columbia, the question remains as to the characteristics of the resulting climates of the various soil landscape regions and, more particularly, how these are modified by physiography to produce the mesoand micro-climates that directly influence soil processes. Further, there is the question of the temperature and moisture conditions that exist within the soil layer itself. These are directly related to climatic conditions experienced above ground.

Temperature cycles near the soil surface follow those in the air with only slight lag. Deeper layers experience a much smaller range or amplitude of change with a lag of one or two months at depths of a few metres. Temperature changes penetrate more deeply in rock and wet sand than in wet clay and least of all in dry sand. In any case, temperatures below 5 or $6 \mathrm{~m}$ are essentially constant throughout the year. Soil moisture conditions are a function of gains through precipitation or snowmelt waters and losses by runoff and evapotranspiration. A discussion of the classification of soil temperatures and moisture regimes is included in Part 2.3 below.

The following sections deal separately with the five major regions of British Columbia. Table 1.2 .1 provides selected climatic data for sites typifying those regions. Table 1.2 .2 presents some contrasting values for stations at low and high elevations in certain regions. 
TABLE 1.2 .1

Selected Climatic Data for Major Soil Landscape Regions: Annual Means

\begin{tabular}{|c|c|c|c|c|c|c|c|}
\hline Region & Stations & $\begin{array}{l}\text { Precipi- } \\
\text { tation } \\
\quad(\mathrm{mm})\end{array}$ & $\begin{array}{l}\text { Evapotrans- } \\
\text { piration* } \\
\text { (mm) }\end{array}$ & $\begin{array}{l}\text { Snowfall } \\
(\mathrm{cm})\end{array}$ & $\begin{array}{l}\text { Temp. } \\
\left.\text { ( }{ }^{\circ} \mathrm{C}\right)\end{array}$ & $\begin{array}{c}\text { Annual } \\
\text { Range } \\
\text { of 'Temp. } \\
\left({ }^{\circ} \mathrm{C}\right)\end{array}$ & $\begin{array}{l}\text { Bright } \\
\text { Sunshine } \\
\text { (Hirs.) }\end{array}$ \\
\hline $\begin{array}{l}\text { Coast } \\
\text { Mountains } \\
\text { and } \\
\text { Islands }\end{array}$ & $\begin{array}{l}\text { Vancouver } \\
\text { Internat' } 1 \\
\text { Airport } \\
\text { Pr. Rupert }\end{array}$ & $\begin{array}{l}1068 \\
2415\end{array}$ & $\begin{array}{l}490 \\
613\end{array}$ & 113 & $\begin{array}{l}9.8 \\
7.8\end{array}$ & 15 & $\begin{array}{l}1930 \\
1035\end{array}$ \\
\hline $\begin{array}{l}\text { Interior } \\
\text { Plateau }\end{array}$ & $\begin{array}{l}\text { Summer land } \\
\text { Pr. George } \\
\text { Airport }\end{array}$ & $\begin{array}{l}296 \\
620\end{array}$ & $\begin{array}{l}295 \\
439\end{array}$ & $\begin{array}{r}74 \\
233\end{array}$ & $\begin{array}{l}8.9 \\
3.3\end{array}$ & $\begin{array}{l}25 \\
27\end{array}$ & $\begin{array}{l}1990 \\
1865\end{array}$ \\
\hline $\begin{array}{l}\text { Columbia } \\
\text { Mountains } \\
\text { and } \\
\text { Southern } \\
\text { Rockies }\end{array}$ & $\begin{array}{l}\text { Cranbrook } \\
\text { Airport } \\
\text { Revelstoke }\end{array}$ & $\begin{array}{r}438 \\
1096\end{array}$ & $\begin{array}{l}337 \\
485\end{array}$ & $\begin{array}{l}178 \\
412\end{array}$ & $\begin{array}{l}5.1 \\
7.2\end{array}$ & $\begin{array}{l}27 \\
25\end{array}$ & $\begin{array}{l}1800 \mathrm{E} \\
1600 \mathrm{E}\end{array}$ \\
\hline $\begin{array}{l}\text { Northern } \\
\text { and } \\
\text { Central } \\
\text { Plateaus } \\
\text { and } \\
\text { Mountains }\end{array}$ & $\begin{array}{l}\text { Dease } \\
\text { Lake } \\
\text { Germansen } \\
\text { Landing }\end{array}$ & $\begin{array}{l}394 \\
525\end{array}$ & $\begin{array}{l}347 \\
332\end{array}$ & $\begin{array}{l}187 \\
257\end{array}$ & $\begin{array}{r}-1.2 \\
0.4\end{array}$ & $\begin{array}{l}32 \\
31\end{array}$ & $\begin{array}{l}1750 \mathrm{E} \\
1755\end{array}$ \\
\hline $\begin{array}{l}\text { Great } \\
\text { Plains }\end{array}$ & $\begin{array}{l}\text { Fort St. } \\
\text { John } \\
\text { Airport } \\
\text { Fort } \\
\text { Nelson } \\
\text { Airport }\end{array}$ & $\begin{array}{l}450 \\
446\end{array}$ & $\begin{array}{l}383 \\
380\end{array}$ & 192 & $\begin{array}{r}1 . ? \\
-1 . ?\end{array}$ & 33 & $\begin{array}{l}2130 \\
1900 \mathrm{E}\end{array}$ \\
\hline
\end{tabular}

* Mean actual evapotranspiration from Phillips (1976), computed using the Thornthwaite water balance method, assuming a soil storage capacity of $100 \mathrm{millimetres}$ of water.

E-Indicates values of sunshine in hours estimated from climatic maps.

\section{THE COAST MOUNTAINS AND ISLANDS}

The marine west coast climates of British Columbia have a relative lack of sunshine, moderate temperatures year round and heavy precipitation, with a maximum in the fall on the North Coast and in the winter on the South Coast. Extensive areas, particularly westerly exposures and higher elevations, 
TABLE 1.2 .2

Comparative Climatic Data for Selected Pairs of Stations

at Low and High Elevation: Annual Means

\begin{tabular}{|c|c|c|c|c|c|}
\hline Region & Stations & $\begin{array}{l}\text { Elevation } \\
(\mathrm{m})\end{array}$ & $\begin{array}{l}\text { Precipi- } \\
\text { tation } \\
(\mathrm{mm})\end{array}$ & $\begin{array}{l}\text { Snowfall } \\
\qquad(\mathrm{cm})\end{array}$ & $\begin{array}{c}\text { Temperature } \\
\left({ }^{\circ} \mathrm{C}\right)\end{array}$ \\
\hline \multirow{2}{*}{$\begin{array}{l}\text { Coast } \\
\text { Mountains } \\
\text { and } \\
\text { Islands }\end{array}$} & Hollyburn & 46 & 1917 & 66 & 10.0 \\
\hline & $\begin{array}{l}\text { Hollyburn } \\
\text { Ridge }\end{array}$ & 951 & 2939 & 811 & 5.1 \\
\hline \multirow{4}{*}{$\begin{array}{l}\text { Columbia } \\
\text { Mountains } \\
\text { and } \\
\text { Southern } \\
\text { Rockies }\end{array}$} & Trail & 433 & 664 & 167 & 8.7 \\
\hline & $\begin{array}{l}\text { Old Glory } \\
\text { Mountain }\end{array}$ & 2348 & 735 & 558 & -1.9 \\
\hline & Golden & 788 & 472 & 204 & 4.8 \\
\hline & Glacier & $124 \varepsilon$ & 1493 & 970 & 2.1 \\
\hline \multirow{2}{*}{$\begin{array}{l}\text { Northern } \\
\text { and } \\
\text { Central } \\
\text { Plateaus } \\
\text { and } \\
\text { Mountains }\end{array}$} & $\begin{array}{l}\text { McLeod } \\
\text { Lake }\end{array}$ & 704 & 629 & 334 & 1.8 \\
\hline & $\begin{array}{l}\text { Pine } \\
\text { Pass }\end{array}$ & 933 & 2057 & 1322 & 0.6 \\
\hline
\end{tabular}

receive in excess of $2500 \mathrm{~mm}$ of precipitation, making them by far the wettest parts of Canada. East-facing slopes and lowlands receive substantially less. Snowfall accounts for a small fraction of the annual precipitation near sea level. The mean annual range of temperature (i.e. the mean temperature of the warmest month minus that of the coldest month) in the outer coastal zone is the smallest in Canada at $10^{\circ} \mathrm{C}$.

A distinct clinatic zone must be recognized over the southeastern lowlands of Vancouver Island, the islands of the Strait of Georgia and the Fraser River estuary. These areas which lie in the rainshadow of the Vancouver Island Ranges and Olympic Mountains have climates approaching the Mediterranean type in that summers are normally dry and warm with a high number of hours with bright sunshine, defined by a condition in which no cloud screens the instrument from the direct rays of the sun. Mean annual temperatures are the highest in Canada at just over $10^{\circ} \mathrm{C}$. The annual'range of temperature of $15^{\circ} \mathrm{C}$ indicates a slightly greater continental influence than on the outer coast. Precipitation amounts at sea level are as low as $650 \mathrm{~mm}$, making this the driest region of the British columbia coast. 
Very different climates are encountered close to those described simply by moving to higher elevations. A transition takes place between moderate, rainy climates and colder, snowy climates. Mean temperatures decline $5^{\circ} \mathrm{C}$ for every $1000 \mathrm{~m}$ increase in elevation. Summers become cool and short. Heavy snowpacks form in the winter and linger into mid-summer. In the extreme case extensive glaciers cover the higher peaks of the coast Mountains.

The large amount of precipitation on the outer coast ensures that soils there are constantly moist. The small annual range of temperature implies slowly changing conditions within these moist soils. Frost is absent in any but extreme surface layers. Heavy snowpacks insulate soils from frost at higher elevations. In the lowlands surrounding the strait of Georgia, warming and drying of the soil normally results in a mid- to latesummer moisture deficit estimated to range from less than 100 to about $200 \mathrm{~mm}$ depending on the site. Again, winter temperatures are moderate with frost penetration slight and infrequent.

\section{THE INTERIOR PLATEAU}

The Interior Plateau lies in the rainshadow of the towering Coast Mountains and Cascades. Precipitation in the semiarid valleys of the south averages as little as 250 to $350 \mathrm{~mm}$ annually. In the more open valleys to the north, amounts reach 400 to $600 \mathrm{~mm}$. Over the rolling uplands, precipitation is considerably greater, reaching $750 \mathrm{~mm}$ or more. Precipitation is well distributed throughout the year with both a winter and a summer peak.

The continental nature of the thermal climate of the region is revealed by an annual range of temperature of $25^{\circ} \mathrm{C}$, double that on the coast. In southern valleys, this is a reflection of hot sumers and moderate winters. In the uplands and in the north, it is more a reflection of cold winter conditions. Mean annual temperatures range from $10^{\circ} \mathrm{C}$ in southern valleys to about $3^{\circ} \mathrm{C}$ in the north and at higher elevations elsewhere. More than $1800 \mathrm{hr}$ of bright sunshine are received annually over most of the Interior Plateau.

Aridity and summer heat are significant factors affecting the soil in southern parts of the region. Strong insolation makes this particularly true of south-facing slopes where very high soil temperatures can result. Further north and over higher ground, more moisture is available and summer heating is less pronounced. Summer moisture deficits are estimated to range from $400 \mathrm{~mm}$ in southern valleys to about $200 \mathrm{~mm}$ near williams Lake and to only $100 \mathrm{~mm}$ near Prince George. The season of moisture deficit includes 
most of April to October in southern valleys, May to September near williams Lake and June to August near Prince George. Moisture deficits are reduced and the season of deficit is shortened at higher elevations throughout the Interior plateau. In winter, frost penetrates the soil to varying depths depending on location, depth of snow cover and type of material. In colder areas, frost penetration to a depth of $50 \mathrm{~cm}$ is common.

\section{THE COLUMBIA MOUNTAINS AND SOUTHERN ROCKIES}

Southeastern British Columbia is an area of great vertical relief with strong climatic gradients. Mountain slopes over which westerly winds must rise receive annual precipitation totals of 1500 to $2000 \mathrm{~mm}$, second only to amounts on coastal slopes. About half of this precipitation falls as snow, leading to the maintenance of glaciers on higher peaks. The narrow valleys of the area are semiarid, receiving 500 to $750 \mathrm{~mm}$, only slightly more than the parched valleys of the southern Interior Plateau.

Mean annual temperatures in the valleys of southeastern British Columbia are close to $5^{\circ} \mathrm{C}$ in contrast to values of $10^{\circ} \mathrm{C}$ for valleys further to the west. This is because the main valley bottoms are at progressively higher elevations as one moves from the Okanagan Valley to the Rocky Mountain Trench (this is illustrated incidentally in Figure 1.4.1) and because Arctic air readily invades valleys close to the Great Plains. Cold winters and cool summers lead to a mean annual range of $25^{\circ} \mathrm{C}$, similar to that over the Interior Plateau. With around $1800 \mathrm{hr}$ of bright sunshine per year, southeastern valleys are less sunny than those to the west which receive in excess of $1900 \mathrm{hr}$. Fewer hours of bright sunshine are received on higher terrain due to increased amounts of cloud. Sunlight is also significantly reduced on steep, north-facing slopes.

The great range of climatic conditions from the valleys to the mountain slopes of southeastern British Columbia dictate a similarly wide range of temperature and moisture conditions in the soils found there. Moisture deficits of $200 \mathrm{~mm}$ or more occur in valley bottoms in the southwestern part of the region. The season of deficit extends from June to September. Further east and north, valley bottom deficits of 100 to $150 \mathrm{~mm}$ are common. Over higher terrain, deficits are limited to a few tens of millimetres in July and August.

THE NORTHERN AND CENTRAL PLATEAUS AND MOUNTAINS

The northern interior has long, cold winters and short, cool summers with moderate precipitation which is well distributed throughout the year. Mean annual temperatures below $0^{\circ} \mathrm{C}$ in the northern valleys with even lower 
values on the slopes indicate the severity of the climate. Precipitation in the valleys averages 400 to $500 \mathrm{~mm}$ per year. Up to $900 \mathrm{~mm}$ fall on much of the mountainous terrain, with more than half in the form of snow. Precipitation increases from west to east, culminating in a distinctly wet area in the Rocky Mountains northeast of Prince George. There the annual precipitation averages from 1500 to $2000 \mathrm{~mm}$, including over $1000 \mathrm{~cm}$ of snowfall. It is estimated that an average of 1700 to $1800 \mathrm{hr}$ of bright sunshine occurs over much of the northern interior.

Due to the short summer and the harsh winter, the soils in the region are frozen to considerable depth from late october to mid-April or May. scattered permafrost exists in some of the most northerly areas. Although evapotranspiration rates are relatively low, the modest amounts of precipitation lead to summer moisture deficits of $100 \mathrm{~mm}$ in soils at low elevation sites removed from the Rocky Mountains.

\section{THE GREAT PLAINS}

The Great Plains region lies to the east of the Rocky Moutains and, therefore, has the most continental climate of any part of the province. What has already been said of the long, cold winters and short sumers of the northern interior also applies here. Since the summers are somewhat warmer east of the Rockies, the mean annual range of temperature exceeds $30^{\circ} \mathrm{C}$ over most of the area and reaches $40^{\circ} \mathrm{C}$ in the extreme northeast, which is only slightly less than the greatest range observed in Canada. Annual temperatures average just above $0^{\circ} \mathrm{C}$ in the Peace River basin and a few degrees lower in the Fort Nelson basin and over higher terrain. Precipitation over the Great Plains is moderate, averaging only 400 to $500 \mathrm{~mm}$ per year. Maximum rates occur during the mid-summer growing season, another continental feature of the climate of the area. Solar radiation is plentiful. Fort St. John has an annual average of over $2000 \mathrm{hr}$ of bright sunshine, closely rivalling Victoria as the sunniest location in British Columbia.

Despite the peaking of the distribution of precipitation in summer months, high insolation and relatively high temperatures in that season produce sufficient demand for water for evapotranspiration to lead to a significant water deficit. Exposed soil surfaces tend to be warm and dry during mid to late summer, particularly on south-facing slopes. Estimated summer moisture deficits of $150 \mathrm{~mm}$ occur in the lower elevation terrain of the region. However, the sumer is short. As in other parts of northern British Columbia, cold winter temperatures soon lead to frost penetration to depths of several metres, particularly in the Fort Nelson basin where scattered permafrost exists. 


\section{FURTHEK READING}

Atmospheric Environment Service, Canada Department of Fisheries and the Environment - numerous publications including climatic maps, normals and data summaries.

Details regarding these various data sources are available from the Atmospheric Environment Semice.

Bryson, R.A. and F.K. Hare, Editors, 1974. World Survey of Climatology: Volume 11, Climates of North America, Elsevier, New York. 420 pp. An in-depth volune including descriptive material but with considerable technical detail.

Chapman, J.D., 1952. The Climate of British Columbia, paper presented to the Fifth British Columbia Natural Resources Conference, University of British Columbia, February 27, 1952. 47 pp.

A readable paper presenting basic information on climatic controls but with empinasis on a description of the climates of the regions of British Colunioiu.

Hare, F.K. and M.K. Thomas, 1974. Climate Canada, Wiley, Toronto. 256 pp. This text contains sections dealing with basic theory, regional climates, applications and metcorological services along with numerous tables of iata. $A$ readable and useful reference.

Phillips, D.W., 1976. Monthly Water Balance Tabulations for Climatological Stations in Canada, DS No. 4-76, Atmospheric Environment Servicc, Toronto. 6 pp plus tables.

A brief paper describes the method. The complete set of tables (only a selection are included in the paperl provides a valuable source of injomation on soil moisture surplus and deficit conditions across Canada. Details ian be obtained from the Atmospheric Environment Service.

Williams, G.P. and L.W. Gold, 1976. Ground Temperatures, Canadian Building Digest, Division of Building Research, National Research Council of Canada, ottawa. 4 pp.

A brief paper oriented toward building design which also provides basic information on the behaviour of the sub-surface temperature regime. 

APPENDIX 9.5

B.C. Agricultural Land Reserves and Livestock Distribution in

Cattle Grazing Areas

excerpted from

Farley, A.L. 1979. Map 38 Agriculture, Agricultural Land Resources and Livestock Distribution, 1975 Atlas of British Columbia, p. 81. University of B.C. Press, Vancouver, B.C. $136 \mathrm{pp}$. 


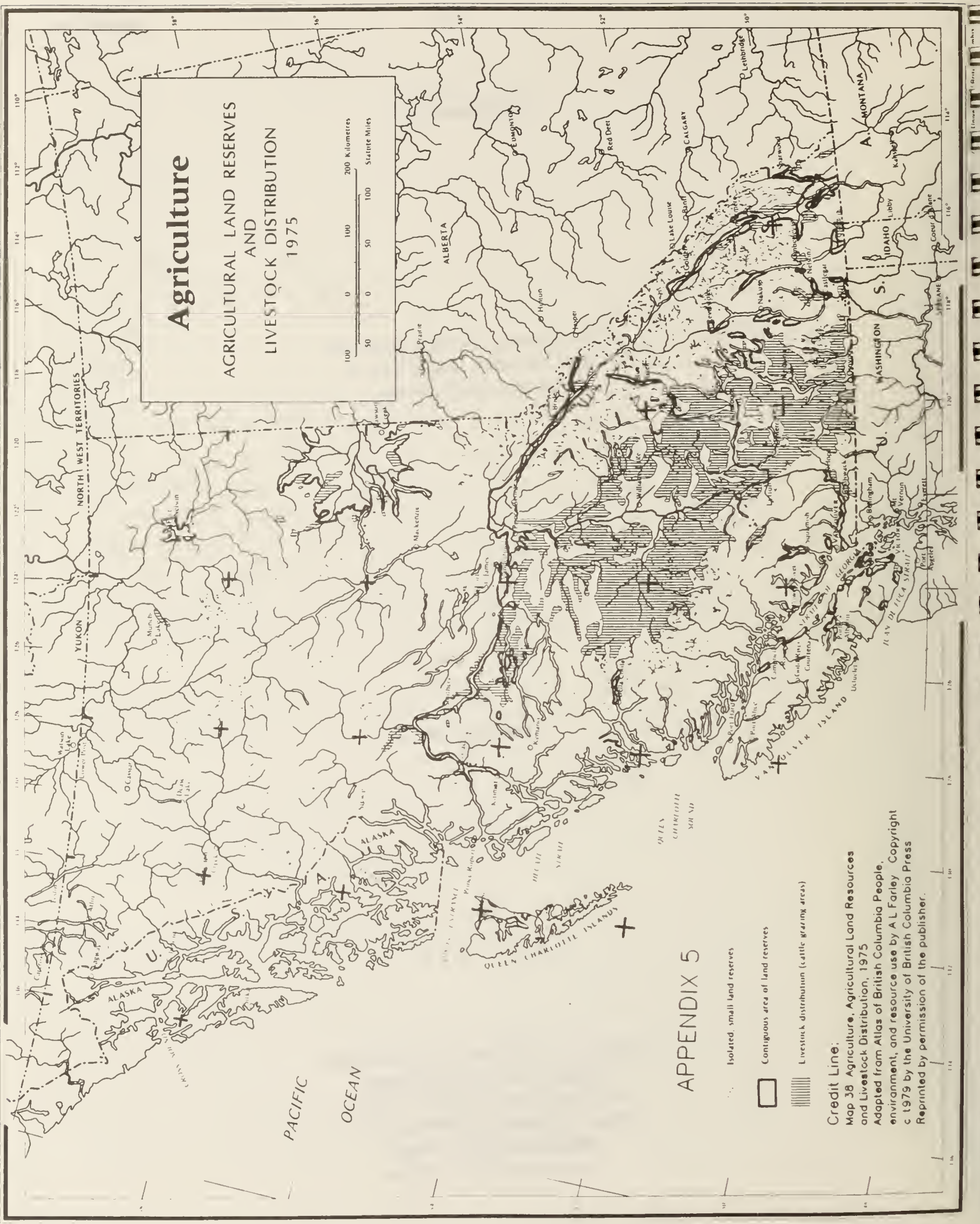





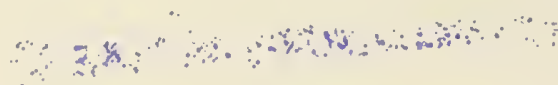

$$
\begin{aligned}
& \therefore \quad \quad \therefore \therefore \text { and }
\end{aligned}
$$

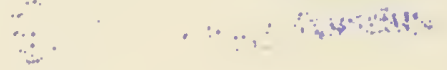

$$
\begin{aligned}
& \therefore \quad \text { औ } \\
& \because \quad \because \ldots \quad \because \cdots \\
& \because \because \cdots, \therefore ; \therefore \text { : } \therefore \\
& \text { 4 }
\end{aligned}
$$

